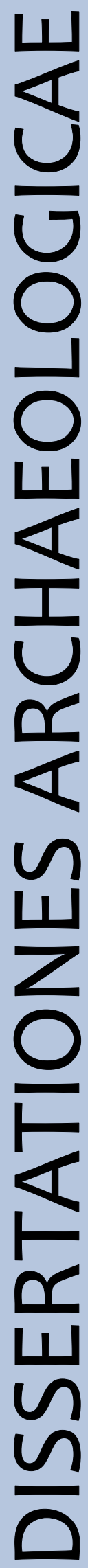

ex Instituto Archaeologico Universitatis de Rolando Eötvös nominatae
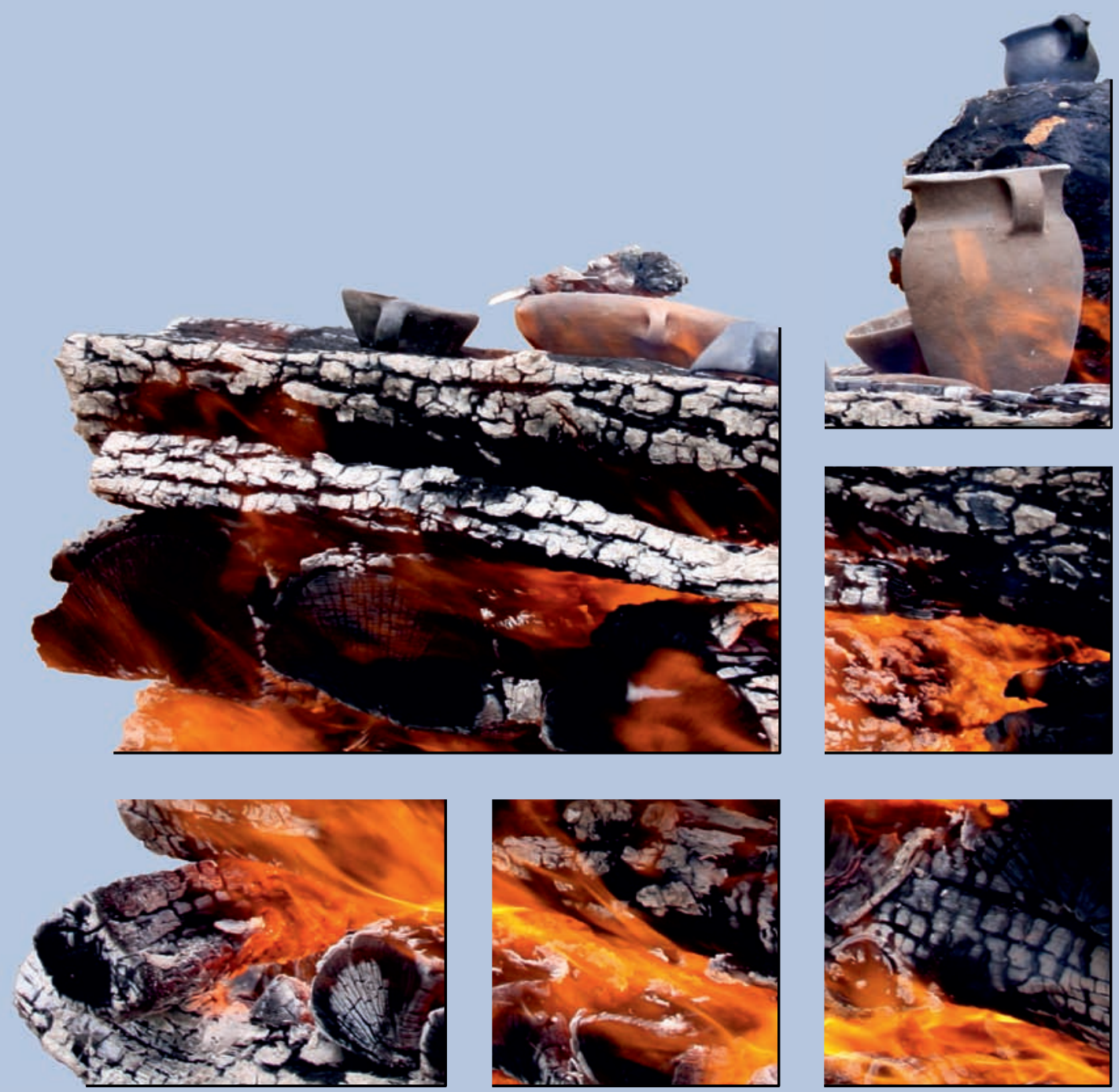

$$
\text { Ser。 3. No。 6. } 2018
$$




\section{Dissertationes Archaeologicae ex Instituto Archaeologico}

Universitatis de Rolando Eötvös nominatae Ser. 3. No. 6.

Budapest 2018 
Dissertationes Archaeologicae ex Instituto Archaeologico Universitatis de Rolando Eötvös nominatae Ser. 3. No. 6.

Editor-in-chief:

DÁvid Bartus

Editorial board:

LÁsZló BARTOSIEWICZ

LÁSZLÓ BORHY

ZoLtÁn CZAJLiK

IsTVÁN FELD

GÁBOR KALLA

PÁL RACZKY

MikLÓs Szabó

TivadAR VidA

Technical editor:

GÁBOR VÁCZI

Proofreading:

ZsófIA KONDÉ

SZILVIA BARTUS-SzÖLLŐSI

Aviable online at http://dissarch.elte.hu

Contact: dissarch@btk.elte.hu

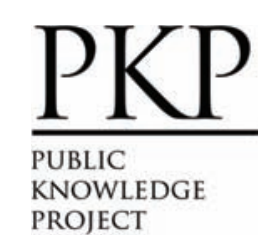

๑ E Eötvös Loránd University, Institute of Archaeological Sciences

Layout and cover design: Gábor Váczi

Budapest 2018 


\section{CONTENTS}

Zsolt Mester

In memoriam facques Tixier (1925-2018)

\section{ARTICLES}

Katalin SEBőK

On the possibilities of interpreting Neolithic pottery - Az újkökori kerámia értelmezési lehetőségeiről

András FüZESI - Pál RACZKY

Öcsöd-Kováshalom. Potscape of a Late Neolithic site in the Tisza region

Katalin SEBőK - Norbert FARAgó

Theory into practice: basic connections and stylistic affiliations of the Late Neolithic settlement at Pusztataskony-Ledence 1

Eszter Solnay

Early Copper Age Graves from Polgár-Nagy-Kasziba

László GuCsi - Nóra Szabó

Examination and possible interpretations of a Middle Bronze Age structured deposition

Kristóf FÜLÖP

Why is it so rare and random to find pyre sites? Two cremation experiments to understand the characteristics of pyre sites and their investigational possibilities

Gábor János TARBAY

"Looted Warriors" from Eastern Europe

Péter MogYoRós

Pre-Scythian burial in Tiszakürt

Szilvia JoHÁczi

A New Method in the Attribution? Attempts of the Employment of Geometric Morphometrics in the Attribution of Late Archaic Attic Lekythoi 
The Roman aqueduct of Brigetio

Lajos JuHÁsz

A republican plated denarius from Aquincum

Barbara HAJDU

Terra sigillata from the territory of the civil town of Brigetio

Krisztina HoppÁL - István VIDA - Shinatria AdHityatAma - Lu Yahui 461

'All that glitters is not Roman'. Roman coins discovered in East Java, Indonesia.

A study on new data with an overview on other coins discovered beyond India

\section{FIELD REPORTS}

Zsolt MESTER - Ferenc CSERPÁK - Norbert FARAGÓ

Preliminary report on the excavation at Andornaktálya-Marinka in 2018

Kristóf FÜLÖP - Denisa M. LÖNHARDT - Nóra SZABÓ - Gábor VÁcZI

Preliminary report on the excavation of the site Tiszakürt-Zsilke-tanya

Bence Simon - Szilvia JohÁcZI - Zita KIS

Short report on a rescue excavation of a prehistoric and Árpádian Age site near Tura

(Pest County, Hungary)

Zoltán CzAJlik - Katalin NovinszKi-Groma - László RupNIK - András BöDőcs - et al. 527

Archaeological investigations on the Süttö plateau in 2018

Dávid BARTus - László BORHY - Szilvia JoHÁczi - Emese SzÁMADó

Short report on the excavations in the legionary fortress of Brigetio (2017-2018)

Bence Simon - Szilvia JoháczI

Short report on the rescue excavations in the Roman Age Barbaricum near Abony

(Pest County, Hungary)

Szabolcs Balázs NAGY

Recent excavations at the medieval castle of Bánd 


\section{Thesis Abstracts}

Rita JENEY

Lost Collection from a Lost River: Interpreting Sir Aurel Stein's "Sarasvatī Tour" in the History of South Asian Archaeology

István VIDA

The Chronology of the Marcomannic-Sarmatian wars. The Danubian wars of Marcus Aurelius in the light of numismatics

Zsófia MASEK

Settlement History of the Middle Tisza Region in the $4^{\text {th }}-6^{\text {th }}$ centuries AD.

According to the Evaluation of the Material from Rákóczifalva-Bagi-földek 5-8-8A sites

Alpár Doвоs

Transformations of the human communities in the eastern part of the Carpathian Basin between the middle of the $5^{\text {th }}$ and $7^{\text {th }}$ century. Row-grave cemeteries in Transylvania, Partium and Banat 


\title{
Öcsöd-Kováshalom. Potscape of a Late Neolithic site in the Tisza region
}

\author{
ANDRÁS FÜZESI \\ Institute of Archaeological Sciences \\ Eötvös Loránd University
}

füzesia@gmail.com

\author{
PÁL RACZKY \\ Institute of Archaeological Sciences \\ Eötvös Loránd University \\ raczky.pal@gmail.com
}

\begin{abstract}
The primary goal of the present study is the publication of the ceramic inventory from Öcsöd-Kováshalom, for which Dissertationes Archaeologicae, being an online journal, can provide the necessary space. We shall principally focus on the possible correlations between vessel forms and their decoration in our analysis, alongside the examination of other traits and dimensions. The ad hoc nature of the analysed finds, i.e. an assemblage of vessels that could be successfully refitted, nevertheless constrains the more general insights that can be drawn from this assemblage. Our primary focus is on three different groups of the site's ceramic inventory, examined according to uniform criteria. The analytical units differ from each other in terms of size and, as a result, the quality of the recorded data. Until now, the so-called Tisza I and Tisza II cultural phases were essentially distinguished qualitatively, based on the differing ceramic style of the two superimposed occupation levels (A and B) at Öcsöd-Kováshalom. We took a bottom-up approach in our analysis, moving from the deposits of individual contexts towards the entirety of the settlement. We also strove to extend the Tisza I and II developmental sequence to a larger region in the southern Hungarian Plain by looking at the contexts with similar ceramic patterns on other sites. The essence of our approach is encapsulated by Katalin Sebök's model for the Late Neolithic of the Tisza region, in which ceramic vessels are enveloped by the different (research) aspect connected with several lines, reflecting the intricate relationships between them. This model takes stock of both the European and the American theoretical approaches and also incorporates elements of various approaches based on system and network theories that figure prominently in modern research agendas. Another inspiring aspect of K. Sebook's initiative is that she moved beyond the traditional boundaries of pottery assessment and sought new avenues for meaningful analyses, which was also one of our priorities in the current assessment of the pottery finds from Öcsöd-Kováshalom. The settlement complex represents a specific initial phase in the Late Neolithic development of the Hungarian Plain in the Tiszazug micro-region. Its position in the Tisza culture's formative phase determined the nature of the site, made up of a tell-like and a single-layer settlement, and its layout of a central settlement area surrounded by smaller settlement clusters within a large triple and segmented enclosure, as well as the community's social and economic milieu. The finds and features brought to light at the site preserve the imprints of complex, multi-scalar processes in the community's life. The main goal of the analysis of the assemblage of 240 refitted and reconstructed vessels was to examine and interpret the possible imprints of these multi-level changes.
\end{abstract}

\section{Introduction}

The complex assessment of the Late Neolithic settlement at Öcsöd-Kováshalom and the preparation of the site report has been underway since 2016 in the Institute of Archaeological Sciences of the Eötvös Loránd University. We presented the initial findings of this work in our first overview covering the site's spatial features and chronology, its stratigraphy and its spatial organisation, ${ }^{1}$ with a special focus on the site's position in the Tiszazug micro-region 


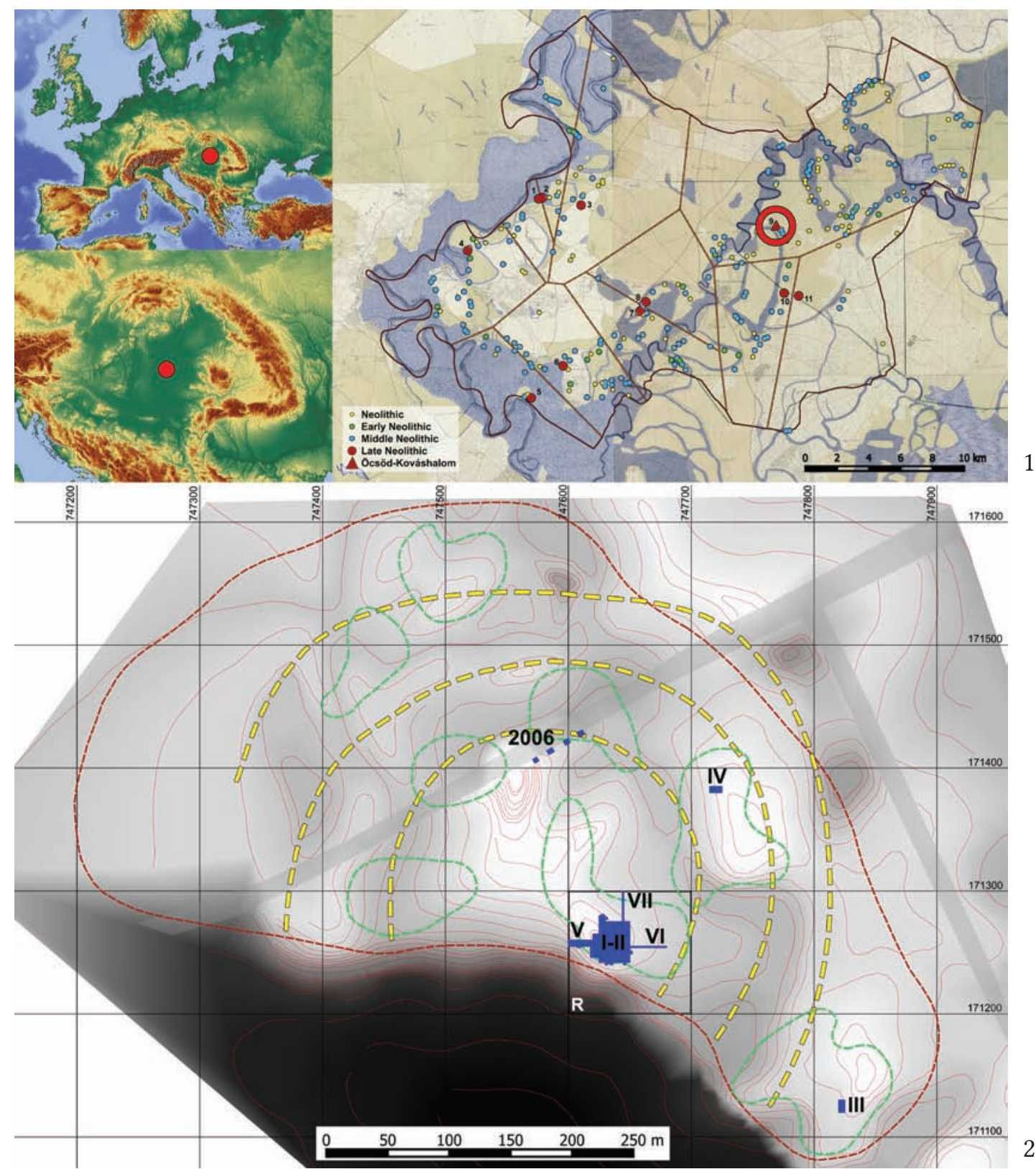

Fig. 1.1 - Location of the Öcsöd-Kováshalom site in the Tiszazug micro-region. The basic map is based on the First Military Ordnance Survey showing hydrological conditions before the nineteenth-century river regulations. The Early Neolithic (green) and Middle Neolithic (blue) sites are shown in the Thiessen polygons of the Late Neolithic sites (red), illustrating the gradual transformation of the Neolithic settlement network (after RACZKy - FÜZESI 2016a), 2 - Plan of the Öcsöd-Kováshalom site. The red dashed line marks the extent of the site, the green dashed lines the settlement clusters, the yellow dashed lines the triple enclosure system identified during the magnetometer survey conducted in 2018. The excavation trenches (numbered I to VII) are marked with blue (after RACZKY - FüZESI 2016a, with modifications).

at the confluence of the Tisza and Körös rivers (Fig. 1), ${ }^{2}$ and on the emergence and development of the Late Neolithic settlement network on the Great Hungarian Plain. The first phase of the site's assessment concentrated on the settlement's larger spatial structures, while our discussion of the finds, including the ceramic inventory, was restricted to a broad general 
overview of the material. In the second phase of the assessment, we strove to prepare the detailed analysis of the find material and we have already published several case studies. ${ }^{3}$ In this study, we continue this assessment, presenting the current state of the assessment of the ceramic finds and its results.

The excavations at Öcsöd-Kováshalom, begun in 1980, were part of the third major wave of tell excavations in Hungary during the twentieth century. Following the pre-World War 2 investigations at Hódmezővásárhely-Kökénydomb by János Banner and at Csóka-Kremenyák by Ferenc Móra, and the excavations undertaken by Gyula Gazdapusztai, József Korek, Ottó Trogmayer and József Csalog on various sites in the 1950s and 1960s, the third major wave of the investigation of tell settlements began in the 1970s. Alongside the fieldwork at Vésztő-Mágor (Katalin Hegedűs, 1972-1976), Berettyóújfalu-Herpály (Márta Máthé and Nándor Kalicz, 1977-1982) and Hódmezővásárhely-Gorzsa (Ferenc Horváth, from 1978), the excavation at Öcsöd-Kováshalom (Pál Raczky, 1980, 1982-1987) can be fitted into this research. ${ }^{4}$ A preliminary report on the findings of the first three excavation seasons was published by the research team, ${ }^{5}$ in which a separate section was devoted to the pottery brought to light during the 1983 season: ${ }^{6}$ the major tendencies in ceramic styles - the supplanting of the ALPC and Szakálhát elements with Tisza ornamental designs - were duly noted, as was the fact that the best analogies to the ceramic inventory can be cited from Szegvár-Tüzköves, Vésztő-Mágor and Battonya-Gödrösök. A more detailed analysis of the pottery finds, with an emphasis on the decoration of the ceramic finds alongside a tentative interpretation of the human depictions and of unusual vessels and clay finds, appeared in the catalogue to a major exhibition on the Late Neolithic tells of Hungary in $1987 .^{7}$ The find assemblage from Öcsöd played a prominent role in the classification of the formal and ornamental attributes of Tisza pottery. ${ }^{8}$ The three-fold chronological sequence (Tisza I-III) based on the sites in the southern Hungarian Plain and the overall interpretation of the Öcsöd site were subsequently accepted by several studies. ${ }^{9}$ The full assessment of the site's material was preceded by a comprehensive study covering the settlement's spatial organisation, the buildings of the two occupation levels, the burials and two features of outstanding importance. ${ }^{10}$ In addition to the refitted vessels from these two features, this study also offered a small selection of Tisza pottery from the site. The full assessment of the ceramic inventory was begun in 2016 after these preliminaries.

This study will focus on a special part of the find material, specifically the refitted and restored vessels, through which we can outline a genuine potscape,${ }^{11}$ which addresses several important issues such as the formal changes in pottery, the development of ceramic styles and the transformation of vessel functions, which in turn can provide a solid foundation for a detailed

\footnotetext{
RACZKY - FÜZESI 2016b; RACZKY - FÜZESI 2018; FÜZESI in press; RACZKY - FÜZESI - ANDERS in press.

Kalicz - RaCZKy 1987a, 13; HegedÜs - MaKkay 1987; Horváth 1987; KaliCZ - RaCZKy 1987b; RaczKy 1987.

RACZKY et al. 1985.

CsORnay et al. 1985.

RACZKY 1987.

RACZKY 1992.

LiCHARDUS - LiCHARDUS-ITTEN 1997.

10 RACZKy 2009. The study was complemented by an assessment of the lithic finds (KaczAnOwsKA et al. 2009) and the animal bone sample (Kovács - GÁL 2009).

11 The expression "potscape" was introduced by Alasdair Whittle and his colleagues for denoting development based on the spatial and chronological patterns of pottery (WhitTLE et al. 2016).
} 
look at stylistic attributes and their possible broader application. ${ }^{12}$ The compositional and technological assessment of the pottery from Öcsöd is currently in progress and shall not be addressed here. However, it must be noted that the first findings of D. J. Riebe and L. C. Niziolek's comparative study of ceramic samples from Öcsöd-Kováshalom, Berettyóújfalu-Herpály and Vésztö-Mágor have already been published, ${ }^{13}$ and the first report on a similar ceramic analysis of the pottery from Hódmezővásárhely-Gorzsa has also appeared. ${ }^{14}$ The technological study of the Tisza- and Lengyel-style pottery from Aszód yielded quite remarkable results. ${ }^{15}$

An immense amount of pottery was brought to light from the $1243 \mathrm{~m}^{2}$ large area investigated at Ȯcsöd, of which 79820 fragments were preserved for future study. A total of 240 vessels could be refitted or reconstructed in drawing, ${ }^{16}$ in other words, these represent the vessels with a complete profile from the site's excavation. Even though this number (proportion) does not appear to be too high compared to the archaeological legacy of other regions and periods, we nevertheless believe that the detailed description and discussion of this assemblage is important for the Late Neolithic research of the Hungarian Plain. The lack of information on Late Neolithic vessel forms is not a shortcoming arising from the lack of excavations, but rather of the significant backlog in the assessment of the excavated material, the fact that most sites have only been partially published and, to some extent, the fragmented condition of the ceramic inventories. The perhaps most eloquent example is the since long known Hódmezővásárhely-Kökénydomb site: János Banner and József Korek mention 210 vessels from this site, but these were never published as part of a comprehensive study. ${ }^{17}$ Considerably more vessels could be refitted from the tell settlement at Berettyóúffalu-Herpály, where a total of 737 vessels were recovered from the six Neolithic occupation levels investigated over the $600 \mathrm{~m}^{2}$ large excavated area - however, only the 84 vessels from House 11, an independent functional unit, were analysed in detail. ${ }^{18} \mathrm{~A}$ total of 610 vessels could be refitted from the tell settlement at Polgár-Csőszhalom and the associated single-layer settlement, of which a larger selection and all the vessels from one of the settlement's wells have been published to date. ${ }^{19}$

The primary goal of the present study is the publication of the ceramic inventory from Öcsöd-Kováshalom, for which Dissertationes Archaeologicae, being an online journal, can provide the necessary space. We shall principally focus on the possible correlations between vessel forms and their decoration in our analysis, alongside the examination of other traits and dimensions. The ad hoc nature of the analysed finds, i.e. an assemblage of vessels that could be successfully refitted, nevertheless constrains the more general insights that can be drawn from this assemblage. Our primary focus is on three different groups of the site's ceramic inventory, examined according to uniform criteria. The analytical units differ from each other in terms of size and, as a result, the quality of the recorded data. The first dataset relates to the entirety of the ceramic assemblage from the site, as registered at the turn of the 1980s-1990s, following the post-excavation selective discarding of the finds and the conservation of the

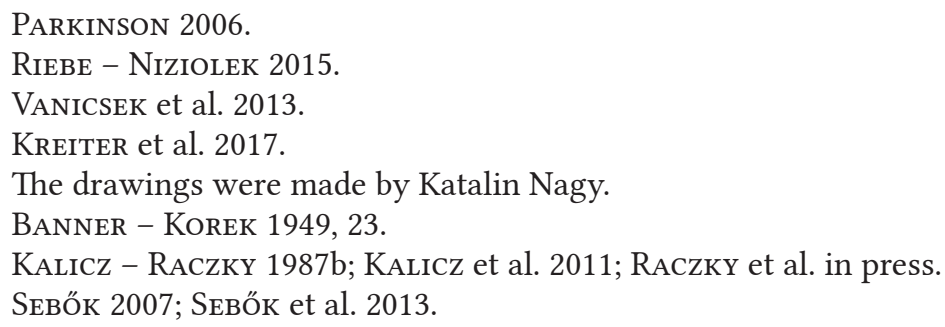


retained material. The second dataset relates to the refitted vessels: following the classification of the vessel types based on formal attributes, the vessels were also analysed in terms of their possible function and use. We strove to map the diachronic changes in the pottery manufacture of the Late Neolithic community with seriation, by comparing the decoration on the vessels with the main functional groups. The third dataset was provided by the finds from two houses (and their debris) of the two main occupation levels: from House 5 representing the early period and House 2 representing the late period. The high amounts of pottery from the two superimposed buildings (Fig. 2) were suitable for controlling the tendencies identified on the basis of the previous two datasets. At the same time, we also strove to compare the two pictures reconstructed from information yielded by the refitted vessels and the fragmented material based on numerical data. Until now, the so-called Tisza I and Tisza II cultural phases were essentially distinguished qualitatively, based on the differing ceramic style of the two superimposed occupation levels (A and B) at Öcsöd-Kováshalom. We also strove to extend the Tisza I and II developmental sequence to a larger region in the southern Hungarian Plain by looking at the contexts with similar ceramic patterns on other sites. ${ }^{20}$

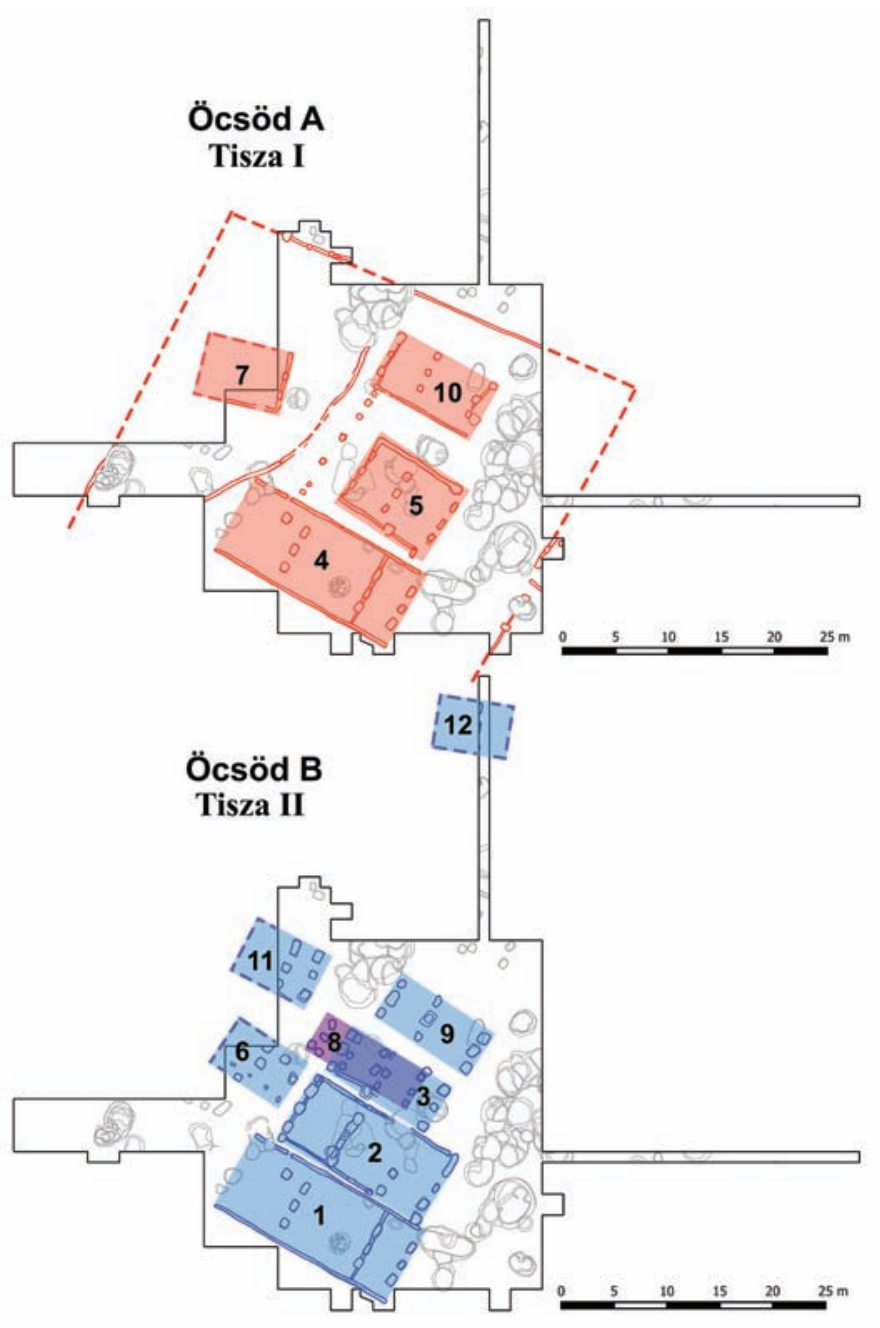

Fig. 2. The excavated area of the stratified Öcsöd-Kováshalom settlement, showing the most important features - the houses and their bedding trenches - of the early (Öcsöd A) and late (Öcsöd B) occupation. The numerals correspond to the numbering of the houses (after RACZKY - FÜZESI 2016a). 
We took a bottom-up approach in our analysis, moving from the deposits of individual contexts towards the entirety of the settlement. The two major European schools of ceramic studies, one essentially espousing a typological approach, ${ }^{21}$ the other a technological one, ${ }^{22}$ have both created their solid methodological foundations and interpretative frameworks. The first concentrates on the ceramic end product, its form and ornamentation, while the other focuses on the chaine operatoire of pottery production and on the material prerequisites and technical skills. The assessment of the finds called for a procedure involving a strict sequence of certain steps that best resembles the method elaborated along the lines set down by A. Leroi-Gourhan. ${ }^{23}$ This procedure and the data it yields is conducive to a perspective focusing on broader structures, in which certain spatial and chronological units, systems of recurring assemblages could be identified.$^{24}$ In our view, the interpretation and assessment of how pottery was produced and used calls for a multi-scalar approach of the type current in American cultural anthropology studies. ${ }^{25}$ As an artefact, pottery took part in many different modes and various dimensions of the complex interactions of one-time communities, and it therefore appears as an archaeological find in the most diverse contexts of a site. Taking our cue from K. P. Hofmann and S. Schreiber, we believe that artefacts can be ultimately set in an interpretative frame incorporating an object's immanent characteristics, contextual relations, typology units and comparative intercultural analyses. ${ }^{26}$ The potential analytical criteria can be grasped to differing extents in the various associations of artefacts on individual sites and one of the tasks of archaeological research and the assessment of the finds is to identify these.

The differential norms governing the use of "coarse ware" and "fine ware" in differing social contexts as demonstrated by M. Furholt on Baden pottery highlights an important point, namely that these social interactions were not uniform even on a single site. ${ }^{27}$ Thus, we cannot presurmise the uniform nature of any one pottery style and any assessment must also involve the identification of various sub-groups. We also took into consideration the analyses on the pottery from the Okolište settlement, where R. Hofmann based his study on the various aspects of style and function (use) in the Late Neolithic social milieu. ${ }^{28} \mathrm{He}$ strove to determine the morphological, decorative and technological attributes as well as the multivariate associations of the pottery, and to reconstruct and interpret the site's social structure and social dynamics.

The essence of our approach is encapsulated by Katalin Sebők's model for the Late Neolithic of the Tisza region, ${ }^{29}$ in which ceramic vessels are enveloped by the different (research) aspects connected with several lines, reflecting the intricate relationships between them. This model takes stock of both the European and the American theoretical approaches and also

21 Strobel 1997; Pavlo̊ 2000; Zalai-GaÁl 2007a; Zalai-GaÁl 2007b.

22 Gomart 2014a; Gomart 2014b; Riebe - Niziolek 2015; Kreiter et al. 2017; Roux 2017.

23 For a discussion of the chaîne opératoire, cf. Delage 2017a; Delage 2017b; Kohring 2013, 109; Roux 2017, 101; SELLET 1993.

24 Childe 1929; Tompa 1929; Tompa 1937; Clarke 1968, 245-298; KAlicz - MAKKay 1977; LuCAS 2017, $187-189$.

25 As set down by Clifford Geertz's "thick description" approach in cultural anthropological studies (GEERTZ 1973; Geertz 2001). For pottery studies, cf. DeBoer - Lathrap 1979; Nicklin 1981; Peacock 1981; Arnold 1985; Graves 1991; Gosselain 1992; Pétrequin et al. 2006; Arnold 2010.

26 Hofmann - Schreiber 2011, Abb. 3.

27 Furholt 2008, 619-622.

28 Hofmann 2013, 67-76.

29 SЕво̋к 2016; SЕво̋к 2018. 
incorporates elements of various approaches based on system and network theories that figure prominently in modern research agendas. ${ }^{30}$ Another inspiring aspect of Sebők's initiative is that she moved beyond the traditional boundaries of pottery assessment and sought new avenues for meaningful analyses, which was also one of our priorities in the current assessment of the pottery finds from Öcsöd-Kováshalom.

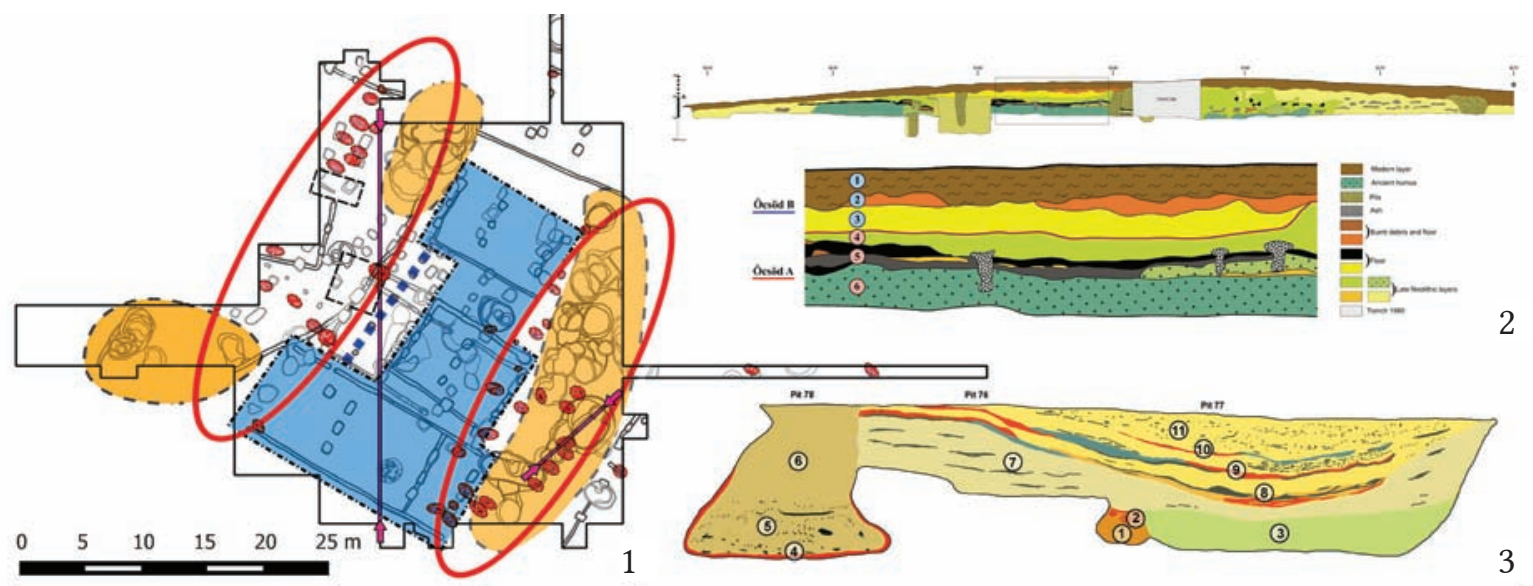

Fig. 3. 1 - The activity zones in the central part of the Öcsöd-Kováshalom settlement, identified on the basis of the excavated features (after RACZKY - FÜZESI - ANDERS in press), 2 - The layer sequence of the settlement on the N-W section of the balk between Trenches I and II. 4-6: Öcsöd A, 1-3: Öcsöd B (after RACZKy - FÜZESI 2016a), 3 - Section of the pit complex at the SE edge of the excavated area (Features 76, 77, 78), showing the phases of its infilling (1-11).

\section{The contexts and associations of the pottery}

\subsection{Context}

More than 200,000 pottery fragments were brought to light during the excavation, of which 79,820 pieces were retained and submitted to conservation. We published the spatial distribution of these finds in an earlier study. The patterns noted in the distribution were interpreted in the light of their spatial context. ${ }^{31}$ Given the stratigraphical and site formation processes typical of tell sites, ${ }^{32}$ we distinguished three basic contexts according to stratigraphic position and whether or not the context was closed (Fig. 3), which are as follows: A: buildings with a clear stratigraphic position and closed context; B: pits with a closed context, but stratigraphically unclear position; and C: various occupation deposits that do not represent closed contexts, but their stratigraphic position can in part be determined. The distribution of the finds varies immensely (cf. Fig. 4 for the numerical data). About $10 \%$ of the entire assemblage was recovered from the buildings and the associated debris, while $61 \%$ from occupation deposits of uncertain stratigraphic position. This immense difference obviously has a bearing on the assessment of the finds. Moreover, the pits that can be regarded as closed contexts (yielding $27 \%$ of the finds) were often dug into each other and often formed complicated complexes.

30 HodDer 2012; KNAPPETt 2013; BARABÁsi 2016.

31 RACZKY - FÜZESI 2016a, 31, Fig. 19. The data are presented in Fig. 5, with a comparison of the distribution of the refitted vessels.

32 Schier 2000, 187-188, Fig. 1; Wolfram 2009, 14-15, 17; PAvúk 2010, 94; Pfälzner 2013, 37-39; RACZky 2015, 236; RACZKY et al. 2015, 23-24, Fig. 2; Chapman 2015, 164. 
The fill of these pits, formed during a process of multiple depositions and infillings, formed a complex sequence (Fig. 3.3). The separation of the layers and of their finds was only partly possible. Despite the stratigraphic field observations, it often proved difficult to associate one or another feature with an occupation level, meaning that the exact position of the finds from these remained uncertain. In these cases, samples were submitted for radiocarbon dating to determine a feature's chronology. Of the 42 AMS dates for the site, eleven were made on samples from pits (eight of these have already been published, the evaluation of the other dates is currently in progress). ${ }^{33}$

\subsection{Activity zones}

The archaeological features, buildings, hearths and well-bounded activity zones uncovered on the stratified habitation mound in the central part of the Öcsöd settlement (Fig. 3.1) provided another interpretative frame for the study of the spatial distribution patterns of pottery. ${ }^{34}$ We reconstructed concentric activity zones in the investigated settlement part that enclosed the houses in their centre. The various pits formed zones

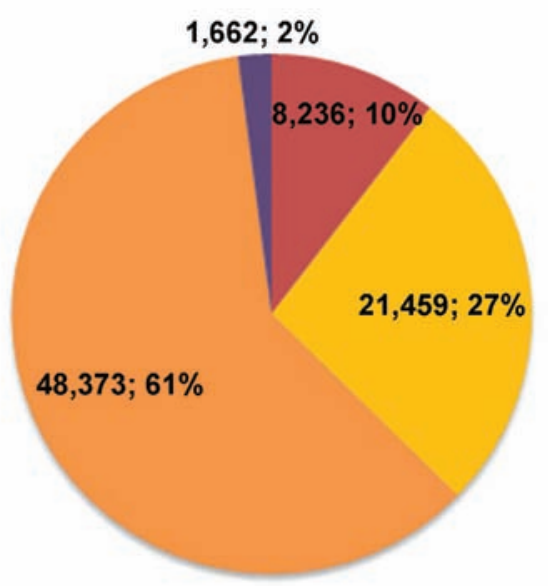

Houses Pits Occupation deposits $\square$ Other

Fig. 4. Distribution of the pottery finds between the different contexts. that were aligned to the orientation of the houses. The large clay extraction pits in the south-eastern area formed a spatial unit owing to their high number, and smaller clusters in the western and south-western zones. The association of a particular feature with a specific house in the activity zones running parallel to the façade of the houses was not possible owing to their proximity to each other. It also remains uncertain whether the features in the western part of the investigated area were associated with the central house cluster or whether they contained the discarded artefacts of the buildings partially falling into this area (Houses 6,7 and 11). The burials similarly formed two zones, adjacent to the zone of the pits. The grave clusters formed smaller units, whose main axes conformed to the north-east to south-west oriented main axis of the house cluster, while individual burials had a north-west to south-east alignment resembling the main axis of the buildings. The field observations enabled the reconstruction of the changes in the settlement's spatial organisation. The increase in the number of houses and the changes in their spatial position led to the disappearance of the earlier inner closed area between Houses 4, 5 and 10 in the later period. ${ }^{35}$ Special activities were associated with the open areas, as indicated by the open-air hearths and a structured deposit of unusual vessels found in the area (described in earlier studies). ${ }^{36}$ The building up of the open areas and the location of various features in these areas reflect a change in the management and use of space as well as its growing intensity. The re-organisation of the settlement's layout also affected other features. Owing to the con-

RACZKY - FÜZESI 2016a, Fig. 20.

RACZKY - FÜZESI - ANDERS in press, Fig. 6.

RACZKY - FÜZESI 2016a, 25, Fig. 15.

RACZKY - FÜZESI 2016b; RACZKY - FÜZESI - ANDERS in press. 
tinuous use of the pits' zone, a part of the burials from the early period had probably been destroyed. It is also possible that the deposition of new burials involved the conscious selection and exhumation of the earlier ones, suggested by the high number of disarticulated human bones recovered from the pits and the fact that most of the burials date from the settlement's late period. ${ }^{37}$ The concentric activity zones reconstructed for the tell-like settlement at Öcsöd-Kováshalom remained unchanged during both occupation levels, although their continuous re-organisation resulted in some shifts and the partial destruction of the early period's relics. The identification of the activity zones and the changes in their spatial organisation offers some clues for the interpretation of the spatial scatter of the ceramic finds.

\subsection{The spatial distribution patterns of the pottery fragments}

The main tendencies in find accumulations were presented in $25 \mathrm{~cm}$ vertical resolution on the maps published earlier (Fig. 5). ${ }^{38}$ The two major superimposed occupation levels (between 0-25 cm and 75-100 cm, respectively) were in part made up of the upper layers of the house debrises and in part of levelling fills, in which pottery occurred but scarcely. A find concentration was only noted in the foreground of Houses 5 and 10 in the early occupation level. A more substantial number of finds was only recorded in a few areas in the debris layer of the houses $(25-50 \mathrm{~cm}$ and $100-$ $125 \mathrm{~cm}$, respectively), principally in the zones between the buildings: between Houses 1 and 6 and in the south-eastern foreground of House 3 between $25-50 \mathrm{~cm}$, and in the area of House 5 (its south-western and north-eastern part) and the open area beside it between $100-125 \mathrm{~cm} .{ }^{39}$ The floor levels of the buildings were represented by the layers between $50-75 \mathrm{~cm}$ and

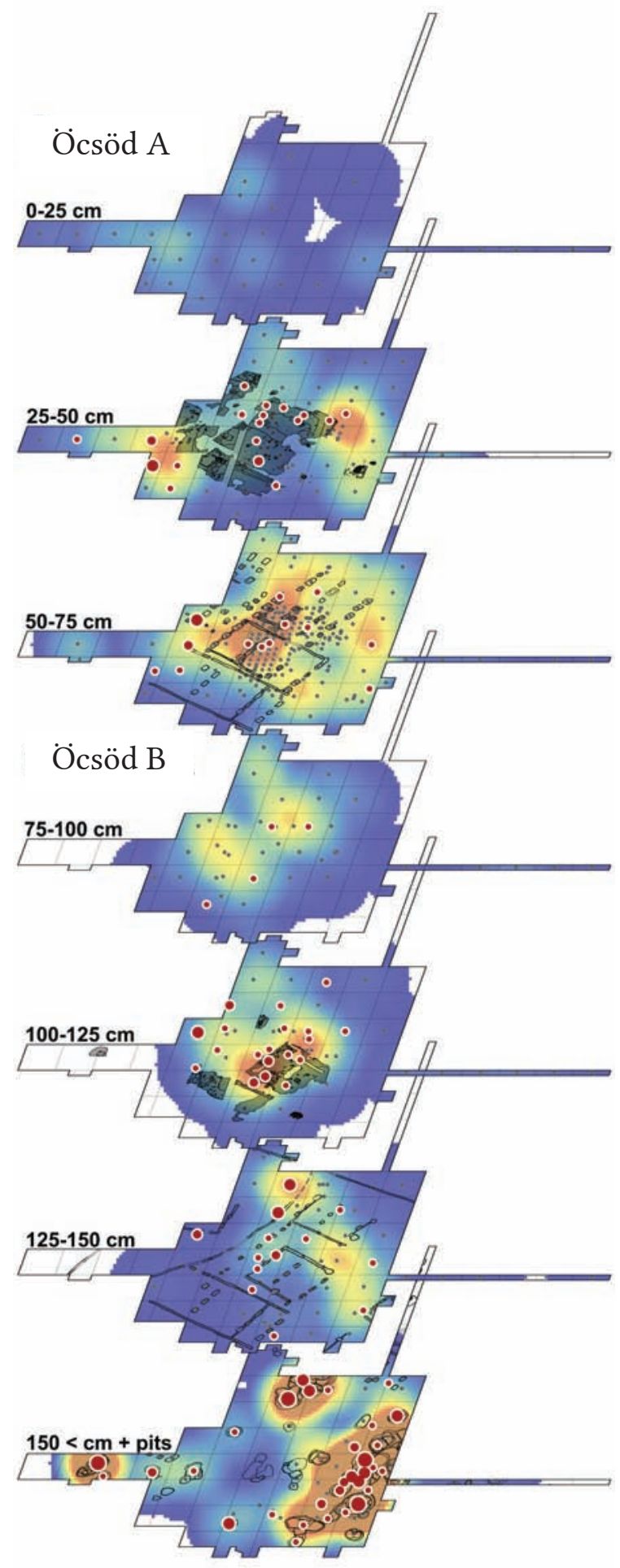

Fig. 5. Spatial distribution of the pottery finds according to levels. The spatial distribution of the fragmented material is shown by the Kernel density, the distribution of the refitted vessels is marked with red circles.

37 RACZKY - FÜZESI - ANDERS in press.

38 Wolfram 2009, 19-20, Abb. 1-2.

39 RACZKy 2009, 105, Fig. 14. 1; RACZKy - FÜZESI 2016a, 25, Fig. 15; RACZKy - FÜZESI 2016b, 26; RACZKy - FÜZESI ANDERs in press. 
125-150 cm, respectively. An immensely high amount of pottery was recovered from the buildings of the late period. The find concentrations covered not only the greater part of the area of Houses 2 and 3, but also extended to their north-western and south-east foreground as well as to the foreground of House 9. The corresponding layer of the early period $(125-150 \mathrm{~cm})$ yielded a scarce amount of finds, most of which lay between Houses 5 and 10 and north-west of House 10.

During the data recording and the assessment, the pits dug into the prehistoric soil were treated separately. The finds showed a concentration in three zones: the highest amount lay in the south-eastern zone of the clay extraction pits, in the foreground of the house cluster. The large pit complexes excavated in the north-western part of the investigated area did not always yield similar quantities of finds, the single exceptions being Pit 159 in the western part of the excavated area and the pit complex of Pits 71, 74, 83 and 84 in its north-western corner.

The spatial distribution of the ceramic finds reflected different find accumulation tendencies in the two occupation levels. With the exception of House 5, the finds of the early period mostly lay in the foreground of the houses. A particularly large concentration was noted in the former open area between the houses, where there were three such concentrations. This concentration must by all means be distinguished from the vessel deposit in the foreground of House 5, in whose case we could demonstrate that the vessel assemblage had been deposited intentionally, making it a structured deposit. ${ }^{40}$ The high number of finds between the house debrises is an indication of the deliberate filling and levelling of these areas. The finds recovered from secondary contexts in these areas mostly dated from the early period and had probably originated from the nearby buildings. In contrast, the greater portion of the finds of the late period were found in their original contexts, in the houses. The finds of Houses 2 and 3 had particularly large concentrations, especially in the buildings' middle and north-western third, which can no doubt be explained by the differential use of internal space. Two major find concentrations were noted on the western and eastern periphery of the debris of adjacent, closely spaced buildings, which can be assigned to the late occupation period on the strength of their stratigraphic position. Given that the late horizon in a sense marked the end of life in this part of the settlement, the deposition of the high amount of finds brought to light from the fill layers outside the house can be seen as a spontaneous process, which needs to be distinguished from the similar phenomena of the early occupation period. ${ }^{41}$

\subsection{The spatial patterning of the refitted vessels}

The spatial distribution of the refitted vessels with complete profiles differs somewhat from the general spatial distribution of the finds as described in the foregoing (Fig. 5). Although the basic tendencies are the same, i.e. the units with higher quantities of finds yielded more refittable and restorable vessels, a few exceptions nevertheless highlight the peculiarities of artefact accumulation. The refitted and the fragmented vessels of the early period mostly originated from a similar location in the case of House 5 and its immediate area. Divergences could be noted in the case of the material from House 7 and certain points of the zone enclosing the buildings. The stratigraphic position of the refittable vessels recovered

40 RACZKY - FÜZESI 2016b, 26, Fig. 2; RACZKY - FüZESI - ANDERS in press.

41 For the distinction between and the identification of natural accumulation of finds and accumulation in the wake of human activities, cf. KvĚTINA - KončELOvÁ 2011; ŘIDKÝ et al. 2014. 
from the buildings of the late period in part differed from that of the fragmented ceramics. The former principally came to light from the middle part of House 2 and the entire area of House 3, from the debris. The refittable vessels also had a greater concentration at the western edge of the investigated area. They accounted for a much greater proportion of the ceramic material than the fragmented pottery among the finds of House 6 as well as in the material from the area to its south. A similar tendency could be noted among the pits dug into the prehistoric soil. The dense concentration of finds enabled the refitting and restoration of higher numbers of vessels; at the same time, divergences could also be noted in the case of a few smaller features (Features 3, 15, 105, 106, 157 and 160), particularly in the south-western quarter of the investigated area. Among these, Feature 105 dug into the debris of House 1 stands out by its form and the structured nature of its fill. Eight vessels, forming an assemblage with a unique composition (U5 1-6, U6 1-2), were deposited in successive fill layers of this unusual, small, beehive-shaped pit. ${ }^{42}$ This assemblage resembles the similar structured deposit of vessels in the foreground of House 5. However, we should not necessarily assume structured depositions in other cases when refitted vessels have a higher proportion than the fragmented material because the differential fragmentation of the assemblages also influenced these ratios.

The spatial positions and contexts of the refitted vessels provide important information for later studies too, and thus we tabulated the find material according to these criteria. The finds of the early and the late horizon are followed by the vessels from the pits, according to the sequence on the plan of the excavation. $42 \%$ of the 240 vessels (101 specimens) can be assigned to one or another of the two occupation horizons. The early period is represented by 59 artefacts, $44 \%$ (26 vessels) of which was recovered from buildings. Of the 42 artefacts assigned to the late period, 29 pieces $(62 \%)$ could be associated with buildings, conforming to the find accumulation model outlined by the spatial distribution of the entire, fragmented material. The finds of the early period could be linked to the subsequent occupation deposits in the open areas between the buildings rather than to closed contexts. The large-scale levelling activities created extraordinary concentrations of finds, a phenomenon observed on other tell settlements too. ${ }^{43}$ The finds recovered from buildings were treated as source material from primary contexts, although with some reservations, while the pottery from the occupation deposits as one originating from secondary contexts.

\subsection{Vessels originating from buildings}

A comparison of the finds from individual houses provides further information on the differential processes of artefact accumulation. There is a great divergence between the proportion of fragmented and refitted vessels in the ceramic material from the buildings of the early and the late period. While the entire, fragmented material reflects the main tendencies as determined by the number of buildings (four early and seven late houses), i.e. with a rough proportion of 1:2 (Fig. 6), the proportion of refitted vessels differs significantly. There are 26 complete vessel profiles from the early houses and 29 from the late ones, and thus in this sense, we may speak of over-representation in the buildings of the early period. 


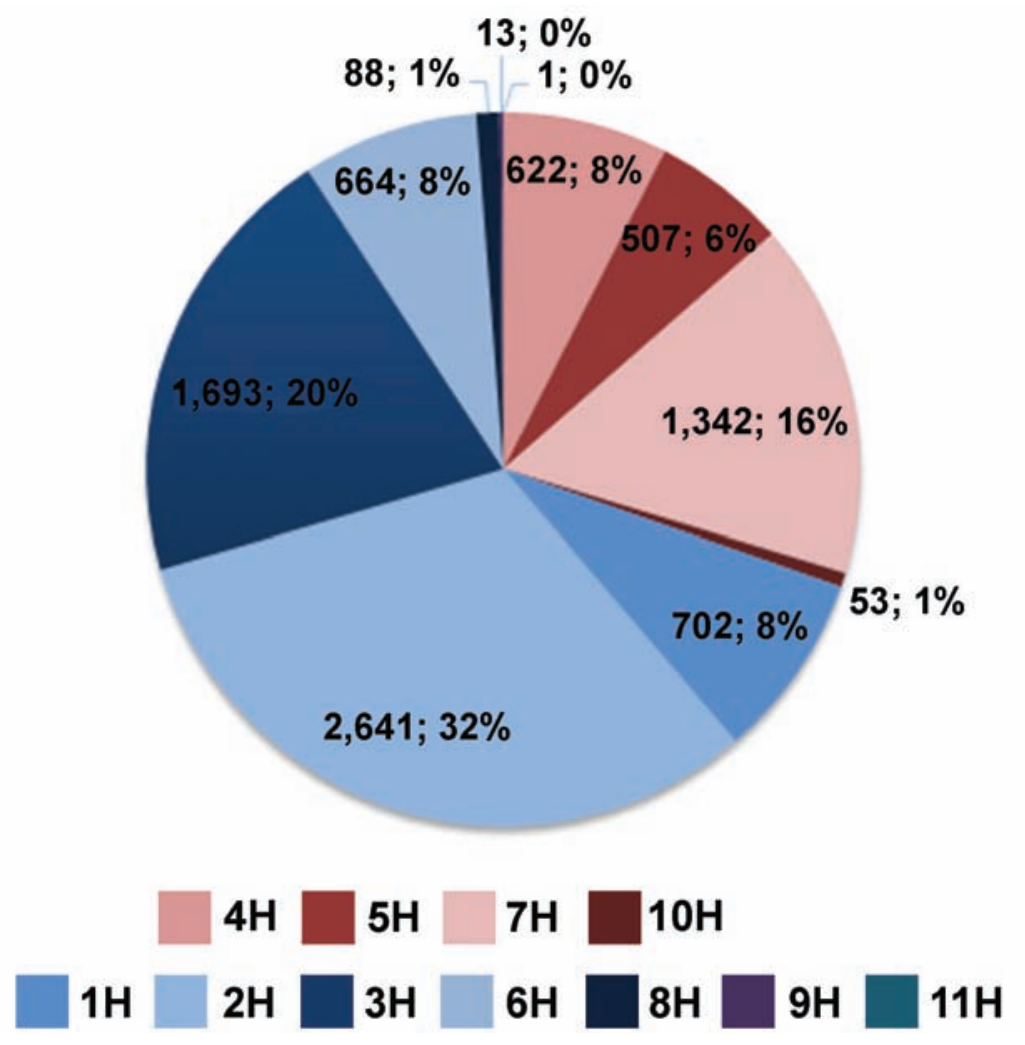

Fig. 6. Distribution of the pottery finds from the houses. The houses of the early occupation are shown in red hues, the houses of the late occupation in blue hues.

We also examined the spatial distribution of the pottery finds inside the houses. We assigned the archaeological remains of houses to four main categories:

- post-holes and bedding trenches representing the foundations,

- floors and their renewals,

- the lower, intact part of the debris,

- the upper, disturbed part of the debris (Fig. 7.1). ${ }^{44}$

The different categories represent diverse artefact accumulation processes, contexts and temporalities that will have to be taken into account during future detailed assessments. Eleven of the twelve houses uncovered at Öcsöd-Kováshalom (Fig. 2) contained archaeological finds, of which the distribution of pottery is discussed here (Fig. 7.2). One striking fact is that only seven of these buildings yielded a more substantial amount of finds: these were the houses that had a well-identifiable debris. Most of these buildings formed a cluster in the central part of the excavated area (Houses 1-5), while two superimposed buildings (Houses 6-7) lay slightly westward of this cluster. With the exception of a single partially excavated house (House 12), the pottery came to light from the foundations of buildings in the northern part of the excavated area (Houses 8-11), representing Category I finds. On the testimony of the sections ${ }^{45}$ no house debris layers were found in this area and thus the layers uncovered here could not be associated with the buildings and were interpreted as levelling and fill layers. These units contained far fewer finds compared to the house debris layers.

For a similar classification, cf. Faragó 2019, 74-77; MARton 2015, 57-59, Fig. 4.1; RAcZky - Sebők 2014, Figs $5-8$.

45 RACZKY - FüZESI 2016a, Fig. 17, right side of the section. Fig. 3.2 shows the same section at a smaller scale. 
There was some diversity in the distribution of pottery inside the buildings yielding a more substantial number of ceramic finds (Houses 1-7; Fig. 7). Considerably more finds were recovered from the foundations (Category I) of the buildings of the later period (Houses 2-3), which can probably be attributed to the secondary redeposition of the finds from the layers that had accumulated earlier and thus these fragments cannot all be treated as the material from the houses. Their percentage ratio did not differ significantly compared to the buildings of the early period (Houses 4-5). We found high numbers of pottery fragments on the floor and in the overlying layer (Category II), closest to their original position, in all houses (242 and 1177 fragments, respectively). In five buildings, this proportion ranged between $50 \%$ and $80 \%$; the proportion for Houses 2 and 3 of the late horizon was $24 \%$ and $17 \%$, respectively. The debris layers (Category III) always contained finds, although their proportion varied considerably, ranging from $5 \%$ to $50 \%$. The debris layers more rich in finds could be linked to the late horizon (Houses 2, 3 and 6). The association between the uppermost part of the debris layers (Category IV) and the houses was uncertain. Only the upper part of the debris of four houses contained finds, which, with the exception of House 5, all dated from the late horizon (Houses 1-3).
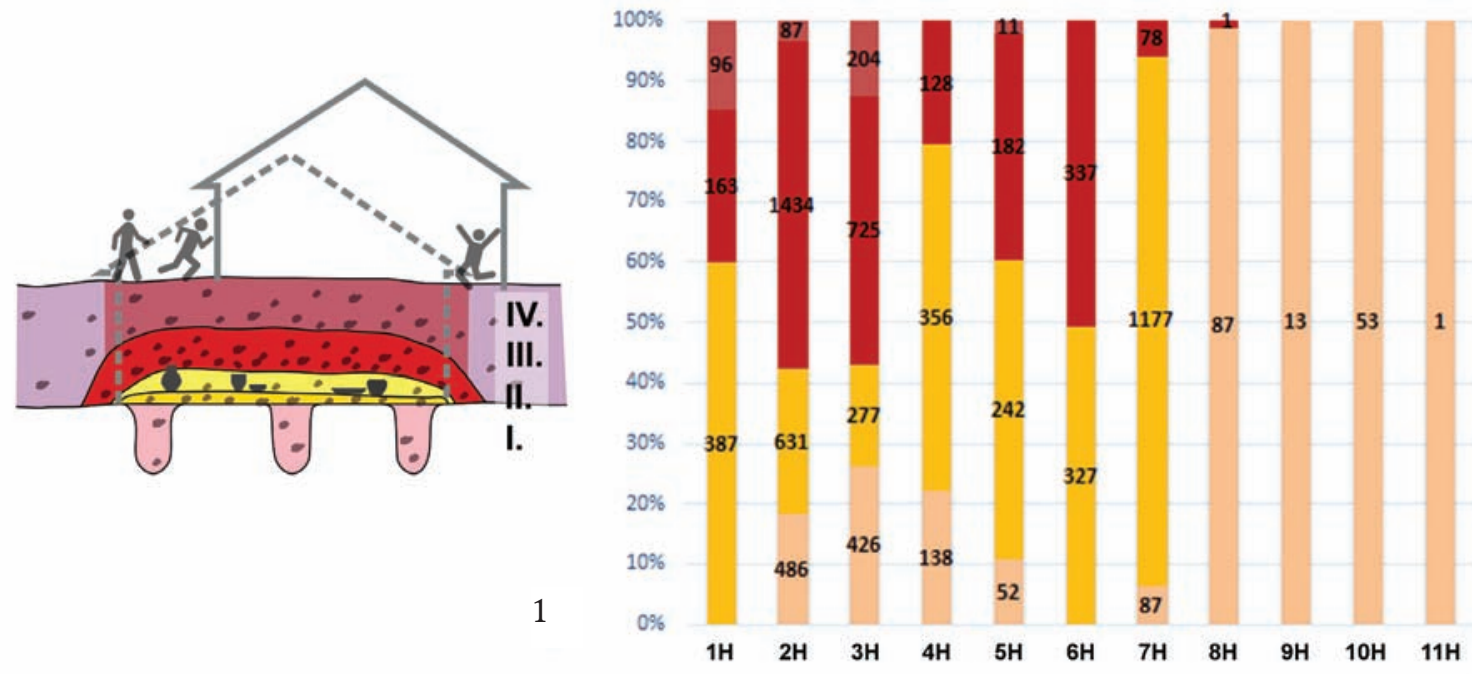

Post-holes and bedding trenches

Floor

Lower debris level

Upper debris level

Fig. 7. 1 - The contexts of the pottery from the houses: I: House foundations (post-holes and bedding trenches), II: floors and their renewals, III: intact lower debris layer, IV: disturbed upper debris layer, 2 - Distribution of the pottery finds according to contexts.

The distribution of refitted vessels according to buildings also varies. Refittable vessels were recovered from nine buildings (Houses 1-7 and 9-10). House 4 of the early horizon has a negative "balance" inasmuch as no more than two vessels could be refitted, despite the higher amount of pottery fragments. In contrast, House 5 yielded far more refittable vessels, eleven in all, than one would have expected from the number of fragments. The proportion of the fragmented material and the refitted vessels is roughly the same, the single exception being House 2, where no more than seven vessels (13\%) could be refitted from the 2641 fragments $(32 \%)$. If the finds from the occupation deposits are also considered, House 5 and its immediate area of the early period becomes even more accentuated. The same area (Houses 2 and 3) is overrepresented in the late period (seven and eleven vessels, respectively). The above analysis would suggest that the distribution of pottery fragments as recorded on excavations was influenced both by deliberate human activities and various taphonomic processes. 
Thus, aside from the extent of pottery consumption, the find material from the buildings of the early and late horizon was greatly influenced by earlier layer accumulation processes and levelling employed as a means of restructuring space. Although the early buildings contained proportionately less finds, these generally came to light from primary contexts (Category II). The higher quantity of finds from the late buildings were predominantly recovered from the debris identified in several layers. It seems likely that later levelling activities most strongly affected the lowermost layer of the early houses. The over-representedness of the middle part of the house cluster (House 5 and Houses 2-3) in both the early and the late horizon indicated that these activity areas remained unchanged despite the partial changes in the settlement's spatial organisation.

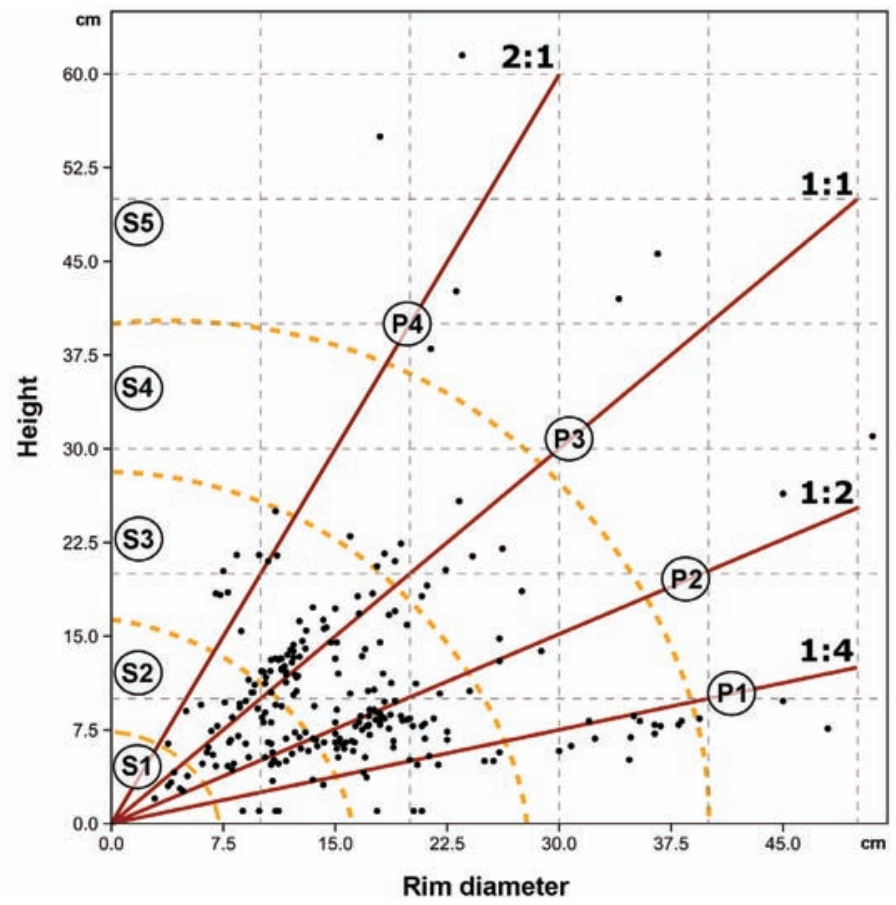

Fig. 8. Classification of the refitted vessels from Öcsöd-Kováshalom according to size. The four main types distinguished according to the proportion between rim diameter and height: P1-P4; the five main types distinguished according to size: S1-S5.

\section{The formal attributes of the refitted vessels}

The find material chosen for this study raises several methodological problems regarding the first analytical criterion. Of the information that can be gained from the 240 refitted and reconstructed vessels, the most obvious is the one relating to form. The spatial distribution of vessel forms does not exhibit any particular patterns in the context of the settlement's features, while it is relevant in terms of the entire settlement for it represents a local range of forms. We found that the formal typology outlined on the basis of the refittable vessels was influenced to a small extent only by the data gained from the fragmented ceramic material.

Several methods have been elaborated for constructing formal typologies, which are in part based on metric data and in part on the geometric classification of formal attributes. ${ }^{46}$

Orton et al. 1995, 153-163; Rice 1987, 215-222; Sinopoli 1991, 46-55; ShePARD 1956/1995, 225-245. 
We considered two criteria for the formal categorisation of the vessels. First, we determined size categories based on height and rim diameter (Fig. 8; Appendix 1). We also examined the maximum diameter in the case of vessel diameters: we found that with the exception of necked vessels, there were no significant differences in variability, and thus we used the first dataset. ${ }^{47}$ The vessels could be assigned to four main groups in terms of their proportions, which roughly corresponded to $1: 4,1: 2,1: 1$ and 2:1 ratios. ${ }^{48}$ We thus distinguished open and closed forms based on these relative data. Open vessels have a higher proportion among the refitted vessels: largely open vessels are represented by 40 pieces, less open vessels by 85 specimens. The highest number of vessels could be assigned to the transitional group (97 specimens): proportions close to 1:1 value represent the less closed category, which also included a few bowls. No more than 17 vessels were assigned to the largely closed category.

We distinguished five categories based on the vessels' absolute dimensions (S1-5). In this case, we considered both the rim diameter and the height data. Miniature vessels were represented by exemplars smaller than $7.5 \mathrm{~cm}$ (S1: 14 pieces). The second group comprised the vessels between 7.5 and $16 \mathrm{~cm}$ (S2: 105 pieces), while the third the vessels between 16 and $28 \mathrm{~cm}$ (S3: 98 pieces). The majority of the refitted vessels fell into these groups. Only a few vessels represented the higher categories: the fourth group comprised the vessels between 28 and $40 \mathrm{~cm}$ (S4: 14 pieces), while the fifth group the vessels over $40 \mathrm{~cm}$ (S5: 8 pieces).

Aside from the metric data, we also used the contour of vessel profiles. We employed the socalled envelope system, ${ }^{49}$ involving classification based on identical size and the similarities between vessel profiles. The main vessel types distinguished using this procedure formed the basis of the assessment and the statistical analyses.

\subsection{Conical vessels}

Conical vessels (Fig. 9) represent the simplest and most frequent formal group. We distinguished three main types based on proportions and dimensions, whose formal differences perhaps also reflect functional differences.

\section{(a) Large plates (T1A)}

In terms of their proportions, the most open vessel type is represented by conical vessels. The proportion between the height and the rim diameter is less than 0.33 in the case of plates and dishes. Vessel sizes vary considerably $(10-48 \mathrm{~cm})$, which led to the separation of two subtypes. Plates are represented by vessels falling into the $S 4-5$ size categories with a diameter of at least $30 \mathrm{~cm}$, while dishes are the smaller exemplars (S2-3). Fifteen vessels were identified as plates in the Öcsöd-Kováshalom assemblage (Fig. 37.9; Fig. 38.5; Fig. 40.4; Fig. 41.7; Fig. 42.2-4, 6; Fig. 50.8-9; Fig. 51.4; Fig. 54.7; Fig. 57.2; Fig. 58.7; Fig. 64.1), whose shared formal attributes (with one exception) are the large lugs, often impressed, set opposite each other. The vessel surface is uneven and unsmoothed on the exterior and smoothed, occasionally polished on the interior. They have a reddish-grey, strongly mottled exterior, not owing to mixed firing conditions, but rather as a result of heat effects during their use. The interior can be either

Howard 1981, Fig. 1.3; Orton et al. 1995, 155-158; Rice 1987, 215-217, Fig. 7.4; ShePARD 1956/1995, 239, Fig. 26.

48 The threshold values between the four groups (henceforth designated as P1-P4) based on the height/diameter proportion are as follows: $0.33,0.66$ and 1.3 . 
reddish or greyish. This vessel type representing coarse ware is ubiquitous on the Late Neolithic sites of the Great Hungarian Plain. ${ }^{50}$

\section{(b) Small shallow dishes (T1B)}

The eleven vessels assigned to dishes fall into the S1-2 size categories (Fig. 38.4; Fig. 41.8; Fig. 44.7; Fig. 46.8; Fig. 50.3-5; Fig. 52.5; Fig. 54.2, 6; Fig. 55.2) and resemble plates not only in terms of their form, but also regarding their other attributes. Nine have lugs to ease handling. However, even though some have an unsmoothed exterior, this was not the general practice for their surface is generally smoothed. Similarly to plates, these vessels also have a mottled surface for the same reason. Dishes occur frequently in Neolithic assemblages, although they were not always distinguished from conical bowls. ${ }^{51}$

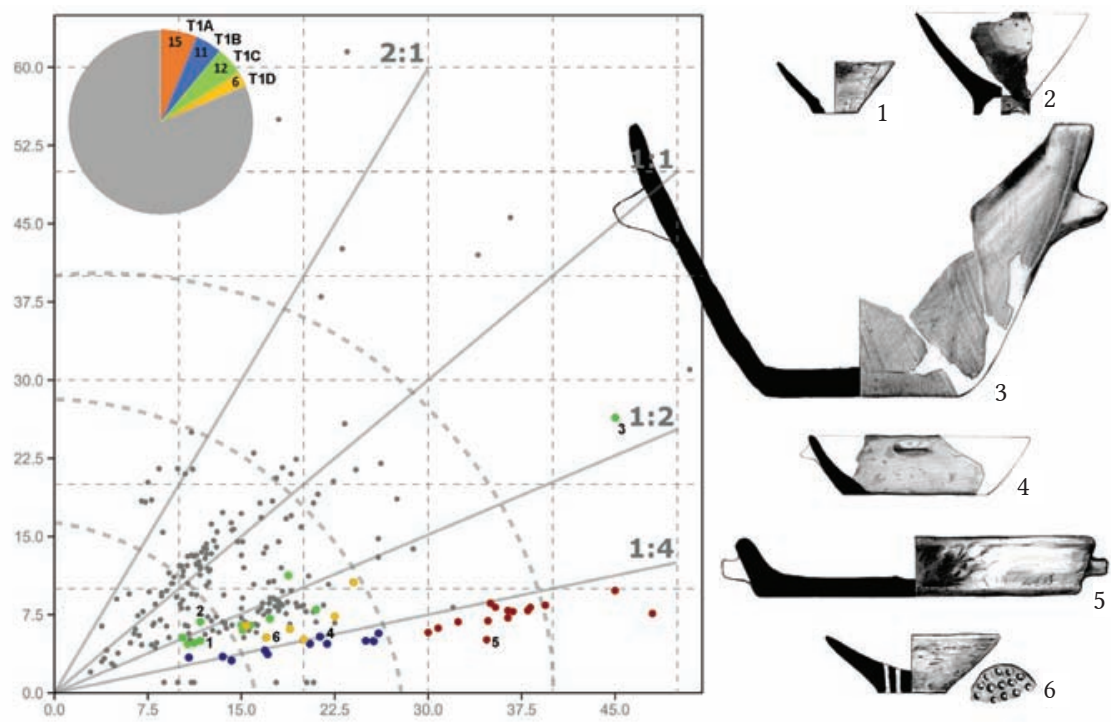

Fig. 9. Distribution of conical bowls according to their main types based on the metric data: 1-3: conical bowls (T1C), 4: dishes (T1B), 5: plates (T1A), 6: strainers (T1D). The pie chart shows the number of conical bowls among the refitted vessels.

\section{(c) Conical bowls (T1C)}

Conical bowls are generally higher and smaller vessels. The eleven vessels found at Öcsöd can be assigned to the P2 and S2-3 categories (Fig. 32.2; Fig. 35.9; Fig. 37.2; Fig. 40.3; Fig. 43.1, 5; Fig. 50.2; Fig. 54.4; Fig. 55.3; Fig. 58.2; Fig. 64.6). In terms of their proportions, the larger exemplars are somewhat flatter than the pieces in the S2 category. One deep bowl with lugs (Fig. 64.6) differs from the other vessels regarding its size and stands closer to plates. Coarser pieces (Fig. 35.9) and exemplars with a more careful surface treatment (Fig. 58.2) both occur among conical bowls; the exterior is most often smoothed, while the interior is more carefully treated. Their colour indicates that they were fired in an oxidising atmosphere, although some greyish-black vessels can also be found (Fig. 40.3).

50 Aszód (Kalicz 1985, Fig. 50. 15), Battonya-Gödrösök (Goldman 1984, Tab. 20. 9), Csóka-Kremenyák (BANNER 1960, Tab. XI. 5, 8; Tab. XII; Tab. XXXIX. 12-13; Tab. XL. 1, 4), Hódmezővásárhely-Gorzsa (GAzDAPuszTAI 1963, Fig. VI. 7), Tápé-Lebő (Trogmayer 1957, Tab. XV. 15), Hódmezővásárhely-Kökénydomb (Banner 1930, Tab. XVI. 4-5; Banner - Korek 1949, Tab. 2.5), Kisköre-Gát (Kovács 2013, Tab. 37. 2, 61. A), Polgár-Csőszhalom (SEBők 2007, 100, Fig. 1. 19).

51 Csóka-Kremenyák (BAnner 1960, Tab. XXXIX. 16-20, 22-24), Hódmezővásárhely-Kökénydomb (BANNER 1930, Tab. XIV. 3), Kisköre-Gát (Konek 1989, Tab. 1; Kovács 2013, Tab. 37. 5, 61. B), Polgár-Csőszhalom (SEвőк 2007, 98, Fig. 1. 1), Tápé-Lebő (Trogmayer 1957, Tab. XV. 12). 
Pedestals occur relatively frequently, most of which are of the low cylindrical variety (Fig. 35.9; Fig. 58.2) with a single exception. ${ }^{52}$ In some cases, the pedestal does not exceed the size of the foot-ring (Fig. 40.3; Fig. 43.1). The pedestal is conical on these vessels. With the exception of two vessels, the pedestalled bowls represent larger vessel sizes (S3). A function as conical lids is also possible in the case of two smaller exemplars (Fig. 40.3; Fig. 43.1). Vessels interpreted as lid-bowls - which may have been used as both bowls and lids - have been identified in the ceramic inventory of other sites. ${ }^{53}$

Aside from a few simple knobs (Fig. 37.2), these bowls are undecorated. The rim is slightly peaked on one bowl (Fig. 54.4). Comparable rim forms occur among the vessels from other Late Neolithic sites too. ${ }^{54}$

(d) Strainers (T1D)

A special group of conical vessels is represented by strainers, of which six exemplars can be found among the refitted and reconstructed vessels (Fig. 34.2; Fig. 40.2; Fig. 41.2; Fig. 46.3; Fig. $63.3,5)$. The proportions of the strainers falling into the S3 size category in part resemble dishes and in part conical bowls. They generally have an unsmoothed exterior and interior, and have mottled surfaces reflecting secondary heat effects. The strainer from House 2 has a roughened exterior and a rim with incisions (Fig. 40.2). The perforations are roughly the same size (with a diameter of $4-5 \mathrm{~mm}$ ), and are restricted to the vessel base, ${ }^{55}$ whose proportions vary compared to the overall vessel size. Some have a strongly constricted base (Fig. 34.2; Fig. 46.3; Fig. 63.3), resembling conical bowls in terms of their form and having a smaller area with perforations (ranging between 6.5 and $8 \mathrm{~cm}$ in diameter). The more flatter forms resemble dishes (Fig. 41.2; Fig. 63.5) and have a larger strainer area (with a diameter of 11-12 cm).

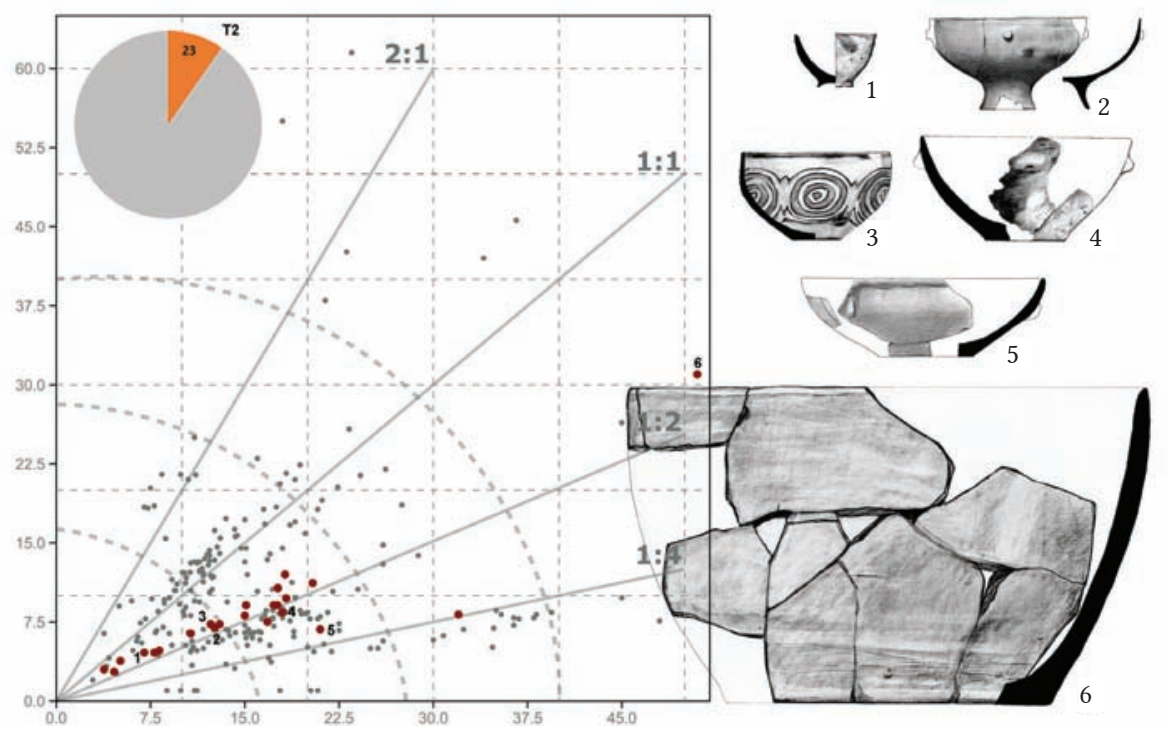

Fig. 10. Distribution of spherical bowls (T2) according to their main types (1-6) based on the metric data. The pie chart shows the number of spherical bowls among the refitted vessels.

52 Polgár-Csőszhalom (SЕвőк 2007, Fig. 1. 2).

53 SЕво̋K 2007, 100, Fig. 1.3.

54 Berettyóújfalu-Herpály (KAlicz - RACzKy 1987b, Fig. 18), Kisköre-Gát (KoReK 1989, Tab. 1. 1, 4), Hódmezővásárhely-Kökénydomb (BANNER - Korek 1949, Tab. 2. 7, 8).

55 Hódmezővásárhely-Gorzsa (Horváth 1987, 40, Fig. 24), Hódmezővásárhely-Kökénydomb (BANNER 1930, Tab. XVII. 4-5, 8-12, 14; BANnER - Korek 1949, Tab. 1. 1), Tiszakeszi-Szódadomb (KovÁcs 2013, Tab. 86. 6). 


\subsection{Spherical bowls (T2)}

In terms of their proportions, spherical bowls can be divided into three different categories (Fig. 10). The flatter type (P1) is represented by two larger bowls (Fig. 35.4; Fig. 56.5), which can be regarded as the variant with curved sides of dishes and plates. Taller varieties (P3) are similarly represented by two bowls, although these can be assigned to the miniature vessels in terms of their size (S1: Fig. 43.2; Fig. 49.6). Most fall into Type P2: they are taller than conical bowls and the proportion of height to rim diameter is generally greater than $1: 2$, with the exception of four vessels.

Spherical bowls include miniature pieces (Fig. 30.2; Fig. 46.7), one of which was fitted with a foot-ring. Most spherical bowls fall into the medium size category (S2-3), although their sizes differ (Fig. 30.3, 6; Fig. 31.3; Fig. 33.5; Fig. 35.7-8; Fig. 37.3; Fig. 39.9; Fig. 43.6; Fig. 44.6; Fig. 45.2; Fig. 49.3; Fig. 52.6; Fig. 55.1; Fig. 58.1; Fig. 63.1). One variant has gently curved sides and is generally plain, save for the small knobs under the rim (Fig. 30.3; Fig. 33.5; Fig. 35.8; Fig. 37.3; Fig. 39.9; Fig. 52.6). The base is often thickened and slightly profiled (Fig. 37.3; Fig. 39.9; Fig. 44.6; Fig. 55.1; Fig. 63.1). Varieties with more strongly curved sides are more carefully made (Fig. 43.6; Fig. 58.1) and have a polished surface in several cases (Fig. 30.6; Fig. 35.7; Fig. 45.2; Fig. 58.1).$^{56} \mathrm{~A}$ taller bowl has an indrawn rim (Fig. 49.3). These bowls are decorated with a variety of applied elements (Fig. 30.6; Fig. 45.2), alongside an articulated rim (Fig. 30.6) and incised patterns (Fig. 35.7; Fig. 45.2). Only one single vessel was fitted with a pedestal (Fig. 58.1): the bowl with strongly curved sides was set on a low conical pedestal. ${ }^{57}$

\subsection{Biconical bowls}

Biconical bowls represent a similarly diverse formal group as conical vessels. Nevertheless, the bowls assigned to this category are characterised by a smaller variability regarding size and proportions (Fig. 11). We distinguished three major types among the 45 vessels assigned to this category based on the position of the carination: low-bellied, middle-bellied and high-bellied biconical bowls. ${ }^{58}$

\section{(a) Low-bellied biconical bowls (T3A)}

Three vessels could be assigned to this type in the studied assemblage (Fig. 37.7; Fig. 39.6; Fig. 45.4).$^{59}$ All three have a pronounced carination line and a strongly constricted lower half. Small knobs are set on the carination of two more open bowls, one of which is fitted with a higher conical pedestal (Fig. 37.7) compared to the previous ones. ${ }^{60}$ The third specimen is a deep bowl, which in view of its proportions represents a transitional form to cups. It has a convex-concave modelling (Fig. 39.6). These vessels are more finely made than the previous ones: the pedestalled bowl has a polished interior, the other two bowls a polished exterior. Their greyish-black colour indicates firing in a reducing atmosphere.

(b) Middle-bellied biconical bowls (T3B)

Represented by 27 vessels, this is the largest group among the refitted vessels. Their proportions are roughly identical (P2) and they fall into the category of medium-sized vessels (S3). There

Hódmezővásárhely-Gorzsa (HoRváth 1987, Fig. 21).

Szegvár-Tüzköves (KoREK 1987, Fig. 3).

SEвőк et al. 2013, Fig. 16.

Polgár-Csőszhalom (SЕвőк 2007, 100, Fig. 1. 14; Sевőк et al. 2013, Fig. 16).

Hódmezővásárhely-Kökénydomb (BANNER - Foltiny 1945, Tab. VII. 15), Kisköre-Gát (Korek 1989, Tab. 1. 7; Tab. 3. 7). 

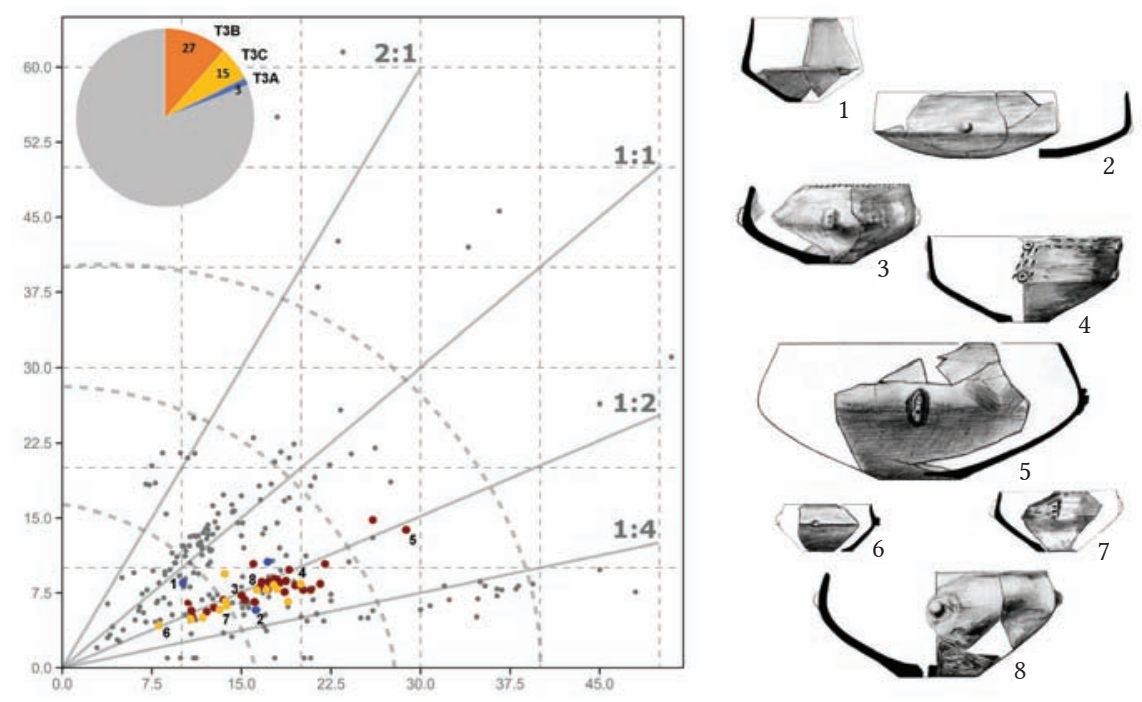

Fig. 11. Distribution of biconical bowls according to their main types based on the metric data. 1-2 Low-bellied biconical bowls (T3A), 3-5 - middle-bellied biconical bowls (T3B), 6-8 - high-bellied biconical bowls (T3C). The pie chart shows the number of biconical bowls among the refitted vessels.

are only two larger bowls in the assemblage whose diameter exceeds $25 \mathrm{~cm}$ (Fig. 36.2; Fig. 43.3). Based on the curve of the carination, we distinguished a more rounded form (Fig. 30.7-8; Fig. 32.1; Fig. 36.2; Fig. 37.5-6; Fig. 39.2; Fig. 44.4; Fig. 45.6; Fig. 57.6; Fig. 58.3; Fig. 61.1-2; Fig. 63.2, 4) and a variant with a sharp carination (Fig. 31.2; Fig. 33.6, 8; Fig. 35.6; Fig. 37.1; Fig. 43.3; Fig. 46.4, 5; Fig. 49.4; Fig. 52.8; Fig. 55.9, 11). ${ }^{61}$ These vessels are finely made and polished on both the exterior and the interior, some are smoothed. Pedestals occur in three cases (Fig. 31.2; Fig. 32.4; Fig. 55.11), all three were fitted to bowls with a sharp carination. One pedestal has a low conical form (Fig. 46.4), the other is medium high, the latter bore traces of red pastose paint on its interior (Fig. 31.2). The bowls in this group often have a mottled exterior and a dark, greyish-black interior.

These bowls are decorated with applied knobs and ribs as well as with designs of incised and painted bands, the latter being more rare. The simple knobs are generally arranged into a row. One sharply carinated bowl had flat round knobs with impressed centre under the rim and on the carination. These knobs were complemented with horizontal and vertical (Fig. 55.9) as well as oblique bands of short stabs (Fig. 46.5). Vertical ribs occur on their own (Fig. 30.7) or alternating with flat round knobs (Fig. 30.8), sometimes combined with a band of short stabs under the rim (Fig. 35.6; Fig. 39.2). Two pairs of small lentil-shaped knobs accompany a vertical rib at its upper and lower end (Fig. 43.3). Black-painted bands served to accentuate the applied elements (Fig. 31.2; Fig. 36.2), or to decorate the rim exterior or interior (Fig. 31.2; Fig. 36.2). One bowl has a band of short stabs on the exterior and a black-painted band on the interior (Fig. 57.6).

(c) High-bellied biconical bowls (T3C)

The biconical bowls of the third type have fairly standard proportions, with most falling into the S2-3 range. Similarly to the previous group, we could distinguish a more rounded form (Fig. 54.5; Fig. 55.5-6, 8, 10; Fig. 57.3) and a variant with a more prominent carination (Fig. 33.3;

61 Hódmezővásárhely-Kökénydomb (BAnner 1930, Tab. XXIX. 1; BAnner - KoreK 1949, Tab. 5. 3), KisköreGát (Kovács 2013, Tab. 39. 3-7). 
Fig. 34.7; Fig. 39.3; Fig. 44.5; Fig. 46.6; Fig. 47.3; Fig. 50.10; Fig. 52.7; Fig. 55.7). ${ }^{62}$ None were set on a pedestal. Their form, surface treatment and firing are identical to the exemplars of the previous group. The rounded form is decorated with round or longish knobs on the carination, and one bowl has a band of short stabs under the rim (Fig. 55.5). Vertical ribs are sometimes set on bowls with a sharp carination (Fig. 39.3), while one bowl retained traces of red pastose paint on its interior (Fig. 52.7).

\subsection{Cups (T4)}

The twenty vessels classified as cups (Fig. 30.5; Fig. 31.6; Fig. 32.4; Fig. 33.2, 4; Fig. 34.6; Fig. 39.7, 10; Fig. 40.5; Fig. 41.4; Fig. 47.2; Fig. 49.7; Fig. 52.4; Fig. 56.4, 6; Fig. 58.4, 6; Fig. 59.1; Fig. 61.4; Fig. 64.2) form a fairly closed group (their proportions fall into the P3 category and their sizes into the S2-3 categories; Fig. 12). Nevertheless, several variants can be distinguished among them, despite their shared attribute of having their widest diameter in the lower third of the body. Cups with curved sides have both a more slender (Fig. 32.6) and a squatter (Fig. 47.2; Fig. 59.1) variety, ${ }^{63}$ with a profile occasionally resembling a gently curving S (Fig. 32.4; Fig. 33.2; Fig. 58.4; Fig. 61.4; Fig. 64.2) ${ }^{64}$ The upper part of the cylindrical cups is slightly constricted (Fig. 30.5; Fig. 39.7; Fig. 40.5; Fig. 41.4; Fig. 49.7; Fig. 56.4, 6), and they include the occasional near-biconical form (Fig. 58.6).

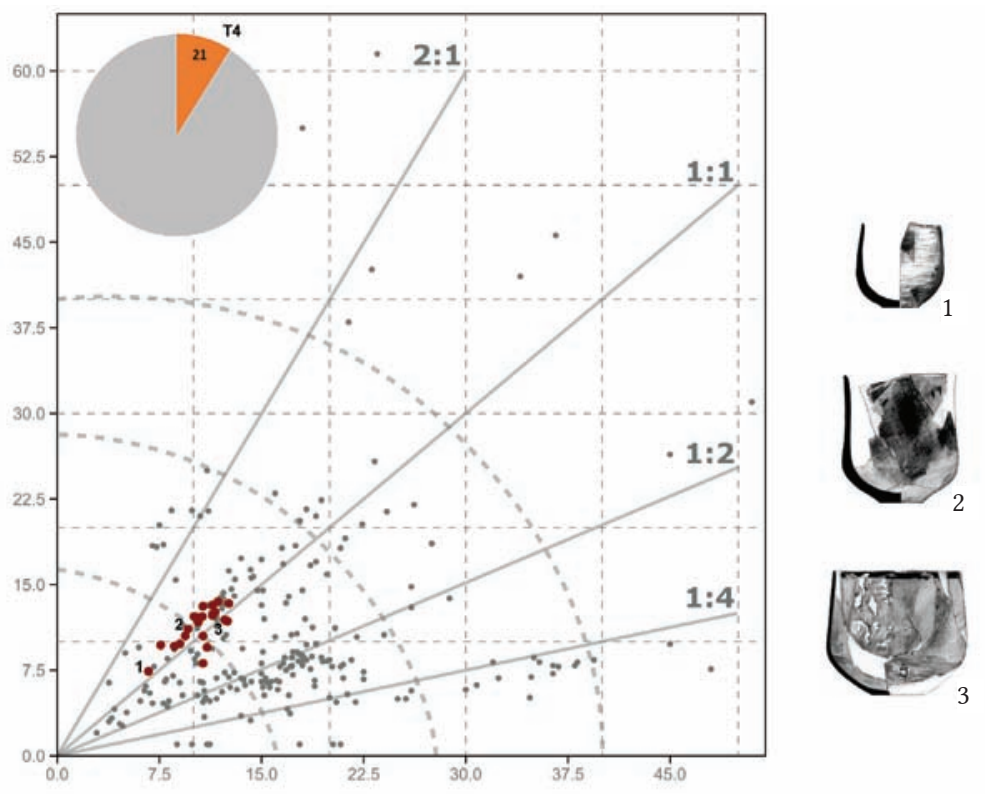

Fig. 12. Distribution of cups (T4) and their main types (1-3) based on the metric data. The pie chart shows the number of cups among the refitted vessels.

The cups assigned to the group are extremely thin-walled vessels, often polished on the exterior and smoothed on the interior. Most were fired in a reducing atmosphere as shown by their greyish-black hues; reddish-coloured exemplars are rare. The interior is always greyish-black. Most are plain, while the decorated pieces are coated with tar preserving inlaid designs

62 Berettyóújfalu-Herpály (KAlicz - RAczky 1987b, Fig. 19), Kisköre-Gát (Kovács 2013, Tab. 38, 6).

63 Sевőк 2009, Type E2; Hódmezővásárhely-Gorzsa (GAzDAPusztai 1963, Tab. V. 4), Kisköre-Gát (KovÁcs 2013, Tab. 44. 3), Szegvár-Tűzköves (Korek 1987, Figs 6-7).

64 Hódmezővásárhely-Gorzsa (Gazdapusztai 1963, Tab. V. 2), Kisköre-Gát (Kovács 2013, Tab. 44. 5), Polgár-Csőszhalom (SЕвőк 2007, Fig. 3. 10-11). 
created with chopped straw (Fig. 40.5; Fig. 56.4, 6). ${ }^{65}$ Black-painted bands appear on both on rim exteriors and interiors (Fig. 41.4; Fig. 56.4), and were also used to create designs covering the entire vessel surface (Fig. 30.5; Fig. 49.7). Traces of red pastose painting were preserved in one cup interior (Fig. 49.7).

Three additional vessels can also be assigned to this group: one has a coarser fabric and surface finish (Fig. 39.10), while the simple knobs on the carination and the vessel's overall modelling points towards small pots. The profile of another vessel resembles the cups with curved sides, although its decoration recalls that of other types: an upward pointing hand-shaped knob combined with bands of short stabs running in various directions (Fig. 34.6). The cups with cylindrical body include an exemplar with an incised design of a zig-zag band around the vessel (Fig. 33.4), a pattern more typically found on other vessel types (T5, T12A).

\subsection{Vessels with curved sides (T5)}

Vessels with curved sides represent the small- and medium-sized groups of closed vessels (P3; Fig. 13), to which 24 vessels could be assigned (Fig. 30.1; Fig. 33.1, 9; Fig. 35.1, 2, 3, 5; Fig. 39.1, 8; Fig. 41.3; Fig. 47.1, 5; Fig. 48.5; Fig. 50.1; Fig. 51.2; Fig. 54.1, 3; Fig. 58.5; Fig. 59.2; Fig. 61.5, 6, 9, 11; Fig. 64.5). The miniature versions include low cup-shaped forms (Fig. 33.1; Fig. 39.8) and taller, pot-like forms (Fig. 35.2). The taller ones have a profiled base (Fig. 35.1, 3). One exemplar resembles a chalice, which also stands out by its finely incised ornamentation (Fig. 35.1).
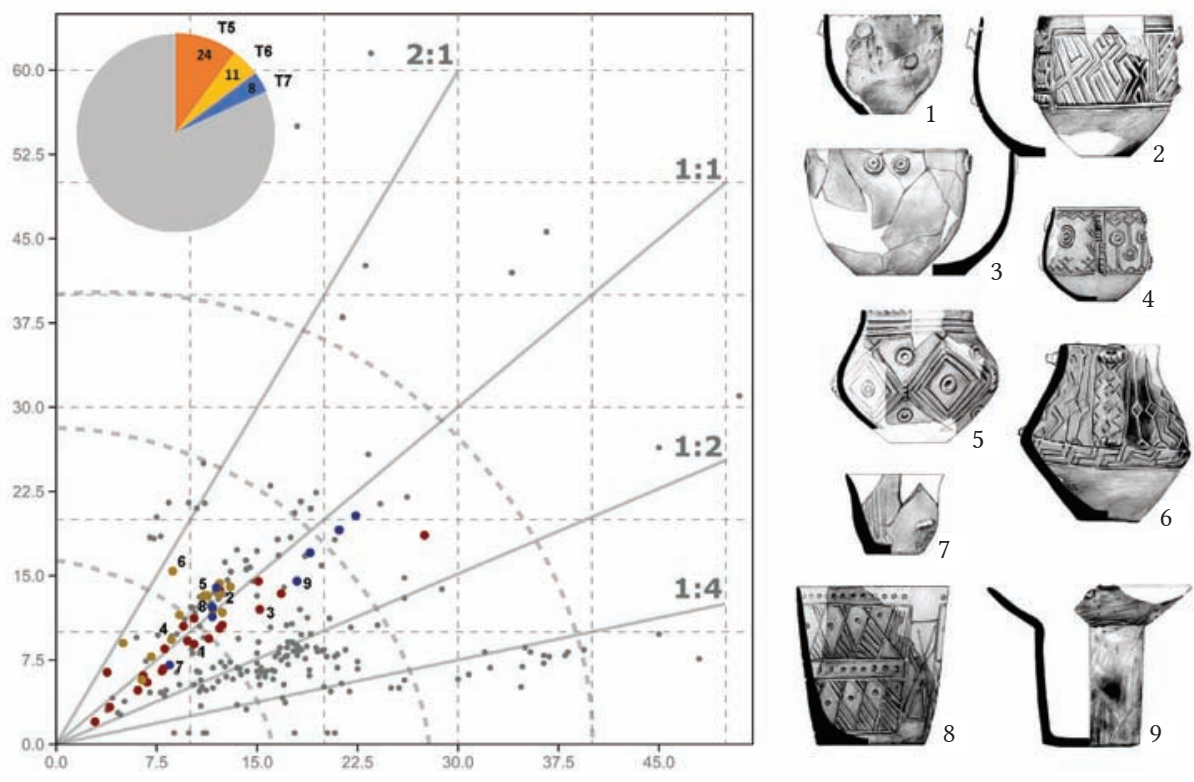

Fig. 13. Distribution of small- and medium-sized closed vessels according to their main types based on the metric data. 1-3 - vessels with curved sides (T5), 4-6 - biconical vessels (T6), 7-9 - conical vessels (T7). The pie chart shows the number of small- and medium-sized vessels among the refitted vessels.

The average sized vessels have both a low cylindrical variant (Fig. 33.9; Fig. 35.5; Fig. 39.1; Fig. 54.1; Fig. 59.2) and one with slightly constricted mouth (Fig. 48.5; Fig. 61.9). Two varieties can be distinguished among the taller exemplars too: one with cylindrical body (Fig. 51.2; Fig. 61.5) and one with constricted mouth (Fig. 41.3; Fig. 47.1, 5; Fig. 58.5). ${ }^{66}$ Their fabric is fine and 
of medium quality, their surface is untreated and uneven, but smoothed on the interior. They generally have a greyish-brown and mottled exterior, and a greyish-black interior.

A chalice-like vessel whose proportions assign it to the lower variant is set on a conical pedestal (Fig. 30.1). ${ }^{67}$ A vessel of similar form set on a low conical pedestal is decorated with lozenges created from impressed dots (Fig. 61.6). A vessel resembling a deep wide bowl stands out by its size, and its function possibly points towards pots and storage jars (Fig. 64.5). Its rim is decorated with incisions and longish impressed lugs are set on the gentle carination, above which there are $\mathrm{W}$-shaped impressed ribs.

This group is characterised by applied decoration. The knobs are set on the carination or under the rim in a row (in one and four cases, respectively), or in two rows, alternating asymmetrically (in six cases). The upper part of a low vessel has pointed knobs arranged into lozenges (Fig. 59.2), while on two vessels the asymmetrically placed knobs are connected with bands of short stabs (Fig. 33.9; Fig. 48.5). Incised designs arranged into panels appear on two vessels (Fig. 47.1; Fig. 61.5), similarly to black painting and traces of a tar coating (Fig. 41.3; Fig. 61.9).

\subsection{Biconical vessels (T6)}

Biconical vessels are similar in size to the previous ones (S2-3), but somewhat taller (P3) (Fig. 13; Fig. 31.1; Fig. 34.4; Fig. 36.4; Fig. 38.3; Fig. 51.1; Fig. 57.7). Their shared attribute is the slightly profiled rim. The sharpness of the carination varies: the flattened spherical variant (Fig. 30.4; Fig. 31.4; Fig. 41.5; Fig. 45.1, 7) has a strongly rounded carination. ${ }^{68}$ Two vessels assigned to this variant have a pronounced rim (Fig. 30.4; Fig. 45.7). Low conical pedestals appear in combination with both the biconical and the flattened spherical variant (Fig. 36.4; Fig. 45.1, 7; Fig. 57.7) ${ }^{69}$ A more slender vessel stands out by its proportions (Fig. 38.3), recalling the form of jugs. The vessels assigned to this group are carefully made, good-quality pieces with a fine fabric. Their surface is smoothed, one undecorated flattened spherical vessel is polished (Fig. 45.1). Their colour is reddish on the exterior and greyish-black on the interior.

This type is predominantly decorated with applied elements arranged in two rows (Fig. 31.4; Fig. 38.3; Fig. 51.1). Some of the flat round knobs in the upper row are perforated (Fig. 34.4; Fig. 36.4; Fig. 45.7). Ten of the eleven vessels assigned to this group also bear incised decoration: four of these designs encircle the vessel body, three are divided vertically, while three are enclosed in panels. Remnants of red painting were detected inside two vessels (Fig. 31.1; Fig. 36.4).

\subsection{Conical vessels (T7)}

Conical vessels are of the same quality and are decorated in a like manner as the vessels of the previous group. However, despite their low number, conical vessels do not form a uniform group. Simple conical forms come in both small and large sizes (S1-3; Fig. 13), alongside low (Fig. 51.5; Fig. 56.3) and more elongated varieties (Fig. 41.1; Fig. 46.2; Fig. 51.6; Fig. 52.1). The distinctive flowerpot-shaped vessels of the Late Neolithic can be assigned to this group. ${ }^{70}$ Most

67 Hódmezővásárhely-Kökénydomb (BAnner 1930, Tab. XX. 11).

68 Sевők 2009, Type E5; Csóka-Kremenyák (BAnner 1960, Tab. XXXVIII. 6).

69 SEвőк 2009, Type E6r; Hódmezővásárhely-Kökénydomb (BAnner 1930, Tab. XX. 9; Tab. XXIX. 2, 4-5; BANner - Korek 1949, Tab. 4. 2), Szegvár-Tűzköves (KoreK 1987, 5).

70 Hódmezővásárhely-Gorzsa (HoRvÁth 1987, Figs 12, 25-26), Kisköre-Gát (Korek 1973, Tab. VIII. 3, Tab. XV. 2; Korek 1989, Tab. 1. 2), Polgár-Csőszhalom (SEBőK 2007, 104-106, Fig. 3. 25), Tápé-Lebő (MórA 1930, Tab. XLI). 
of the conical vessels from Öcsöd have a flat rim or, more rarely, a slightly everted $\operatorname{rim},{ }^{71}$ the latter represented by a single exemplar (Fig. 46.2).

Two cylindrical vessels with a widening upper part represent a special variant in terms of their form. The smaller one has a funnel-like rim (Fig. 52.2), the larger one has a widening rim with a right-angle break (Fig. 42.5). The upper part of the latter resembles the form of low-bellied biconical bowls.

These vessels are decorated with pairs of knobs set underneath each other (Fig. 46.2; Fig. 51.5) and knobs combined with a perforation under the rim (Fig. 51.6; Fig. 56.3), similarly as on biconical vessels. Seven of the eight vessels are decorated with incised patterns which, with a single exception, are arranged in panels. One small vessel bears the rudimentary elements of an intricate incised design (Fig. 41.1). Remnants of red painting could be detected on a seemingly plain vessel (Fig. 52.2).

\subsection{Pots}

Pots are closed (P3), medium- and large-sized vessels (S3-4) characterised by curved sides. Similarly to biconical bowls, three types can be distinguished based on the position of the greatest diameter (Fig. 14). Their fabric and their surface treatment is coarser than of the previous group. Their exterior is unsmoothed and uneven, their interior is smoothed. Owing to secondary heat effects, their exterior is reddish-dark grey with mottling, their interior is reddish or greyish-black.

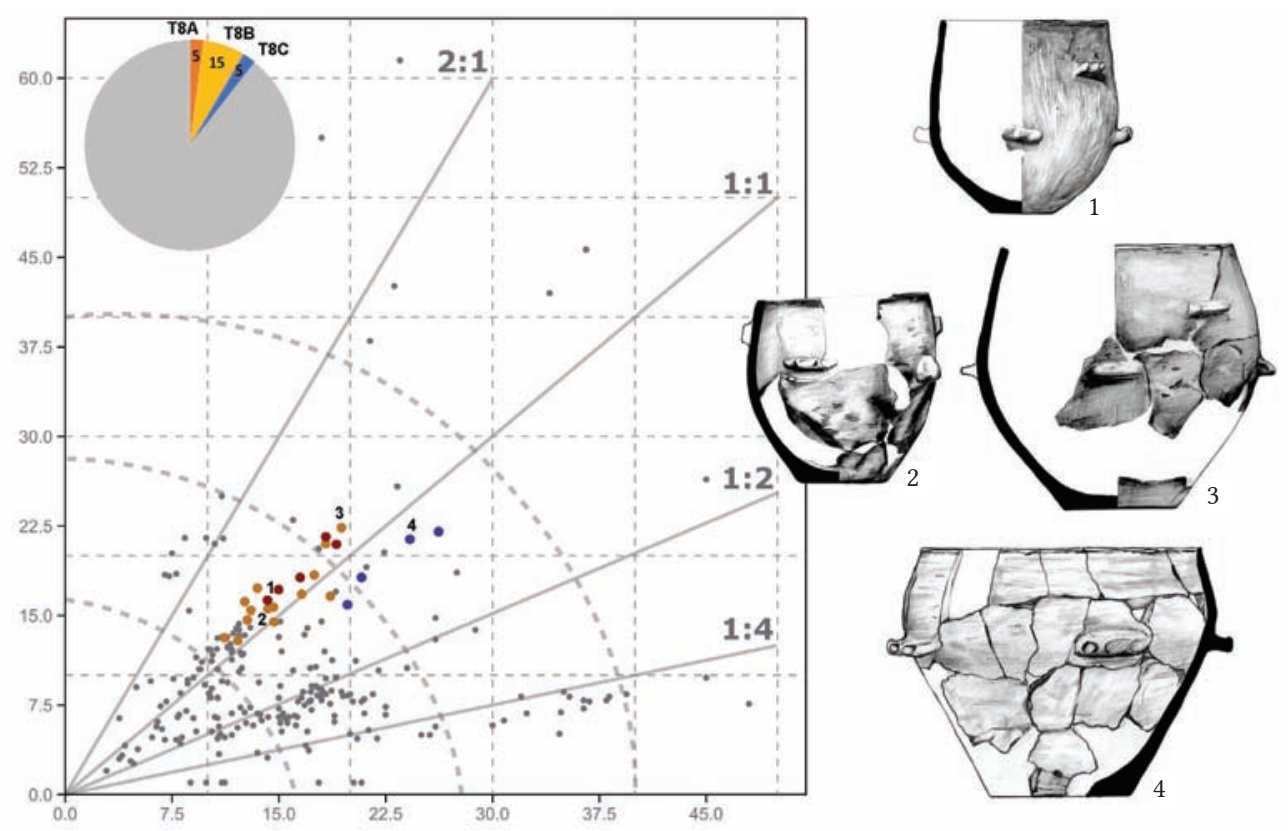

Fig. 14. Distribution of pots according to their main types based on the metric data. 1 - Low-bellied pots (T8A), 2-3 - middle-bellied pots (T8B), 4 - high-bellied pots (T8C). The pie chart shows the number of pots among the refitted vessels.

For the typology of flowerpot-shaped vessels, cf. SEвőK 2009, Tab. 58, Types V1-14.

71 Berettyóújfalu-Herpály (KAlicz - RAczky 1987b, Figs 22-23), Hódmezővásárhely-Gorzsa (Horváth 1987, Fig. 14), Hódmezővásárhely-Kökénydomb (BAnner 1930, Tab. XX. 13, Tab. XXX. 5; BAnner - Korek 1949, Tab. 3. 7; Tab. 4. 1, 3), Kisköre-Gát (Konek 1973, Tab. 15. 9-10; Konek 1989, Tab. 1. 9-10), Szegvár-Tűzköves (KoReK 1987, Fig. 8), Vésztő-Mágor (Hegedüs - MAKkay 1987, Fig. 18). 
(a) Low-bellied pots with curved sides (T8A)

The vessels assigned to this type (Fig. 49.1, 2; Fig. 51.3; Fig. 57.4; Fig. 64.4) have their greatest diameter in the lower third of the vessel body. They represent a standard variant in terms of their size and proportions. ${ }^{72}$ With the exception of a single exemplar, their decoration is by and large similar, made up of longish lugs set obliquely under the rim and on the carination.

(b) Middle-bellied pots with curved sides (T8B)

Middle-bellied pots dominate this vessel type (Fig. 32.3; Fig. 36.1; Fig. 37.8; Fig. 43.4; Fig. 44.9, 10; Fig. 47.6, 8; Fig. 49.5; Fig. 50.6, 7; Fig. 56.2; Fig. 57.1, 5), among which barrel-shaped variants with less curved sides (Fig. 50.6) ) $^{73}$ and globular varieties (Fig. 32.3) both occur. Pot rims are usually flat; the rim is slightly articulated (Fig. 37.8; Fig. 47.8) or more prominently so on two vessels (Fig. 56.2; Fig. 57.5). They are decorated with applied ornaments set in a row on the carination (Fig. 56.2; Fig. 57.1, 5), or in two rows, alternating under the rim and on the carination (Fig. 32.3; Fig. 37.8; Fig. 43.4; Fig. 49.5).

(c) High-bellied pots with curved sides (T8C)

No more than four vessels represent the high-bellied variant in the ceramic assemblage discussed here (Fig. 40.7; Fig. 44.8; Fig. 45.3; Fig. 47.7). Their sizes are similar to the group of low-bellied pots, although they are wider and more open. Their decoration is made up of lugs set in a row on the carination. ${ }^{74}$

\subsection{Jugs and amphoras (T9A-B)}

Vessels with a distinct neck are represented by two main variants. Smaller jugs (Fig. 31.5; Fig. 33.7; Fig. 34.5; Fig. 41.6; Fig. 46.9; Fig. 48.1, 2, 3; Fig. 59.3; Fig. 61.3; Fig. 64.3) can be assigned to the S3 size category, while larger amphoras (Fig. 32.6; Fig. 60.1; Fig. 62.1) to the S5 size category (Fig. 15). One miniature vessel can be assigned to this formal group (Fig. 59.3). The small vessel from Grave 46 has a biconical body with two small lug handles at the junction of the cylindrical neck and the low shoulders. ${ }^{75}$

Among jugs (T9A), variants with a flattened spherical body (Fig. 31.5; Fig. 33.7; Fig. 34.5; Fig. $64.3)^{76}$ and barrel-shaped varieties (Fig. 41.6; Fig. 46.9; Fig. 48.1-3; Fig. 61.3) ${ }^{77}$ represent two separate types. One general trait is that there is no pronounced separation between the neck and the shoulder, with most vessels having low shoulders and conically narrowing mouth. In contrast, amphoras have an articulated neck; a similar neck form can be noted on two jugs (Fig. 31.5; Fig. 64.3). ${ }^{78}$

Jugs are generally provided with two rounded elbow handles set opposite each other on the shoulder (Fig. 41.6; Fig. 48.1-3; Fig. 64.3), sometimes in combination with impressed ribs at the

Battonya-Gödrösök (Goldman 1984, Tab. 24. 5).

Battonya-Gödrösök (Goldman 1984, Tab. 24. 4).

Hódmezővásárhely-Kökénydomb (BAnner 1930, Tab. XIX. 1; Tab. XX. 17).

Miniature and small-sized jugs: Berettyóújfalu-Herpály (KALICZ - RACZKy 1987b, Fig. 16; Kalicz et al. 2011, 51), Hódmezővásárhely-Gorzsa (Horváth 1987, Fig. 11), Hódmezővásárhely-Kökénydomb (BANNER 1930, Tab. XX. 5-6), Csóka-Kremenyák (BAnner 1960, Tab. XXXVI. 10).

SЕвőк 2009, Type F1; Battonya-Gödrösök (Goldman 1984, Tab. 18. 4; Tab. 22. 2), Csóka-Kremenyák (BANNER 1960, Tab. XXXVII. 32), Vésztő-Mágor (Hegedűs - Makkay 1987, Fig. 20).

7 Seвőк 2009, Type F2; Battonya-Gödrösök (Goldman 1984, Tab. 18. 9), Kisköre-Gát (Korex 1973, Tab. VIII. 2 , Tab. XVI. 6, 8; Konek 1989, Tab. 3. 8; KovÁcs 2013, Tab. 53. 6, Tab. 54. 5).

Seвők 2009, Type F3; Tápé-Lebő (Trogmayer 1957, Tab. XIV. 2). 
lower handle attachment (Fig. 33.7; Fig. 61.3). ${ }^{79}$ Ribs arranged into various patterns occur on jug bellies (Fig. 61.3). Aside from various applied elements, this ceramic type is often decorated with black-painted bands, most often on the neck, in line with the handles, and on the belly. Remnants of a linear pattern survived on one jug among the refitted vessels (Fig. 41.6). We identified several black-painted jugs and amphoras in the fragmented material. A larger vessel (S4) with globular body and narrow conical neck bears a black-painted design of wide brushstrokes composed of special ornamental elements and large dots arranged in groups. ${ }^{80}$

Three amphoras (T9B) with tall cylindrical neck, curved shoulders and rounded belly among the refitted vessels are decorated with an elaborately structured incised pattern. ${ }^{81} \mathrm{~A}$ similar incised design can be found on a jug, which resembles amphoras in terms of its form, but can nevertheless be assigned to jugs in view of its modelling (Fig. 31.5).

\subsection{Storage jars (T10)}

The refitted vessels include four storage jars (Fig. 15), which represent the barrel-shaped (Fig. 39.5; Fig. 43.7) ${ }^{82}$ and the biconical variant (Fig. 52.3; Fig. 59.4) ${ }^{83}$ of these vessels. There are major differences between the two types in terms of their proportions (the barrel-shaped variety can be assigned to the $\mathrm{P} 4$ category, the biconical one to the $\mathrm{P} 3$ category). These vessels have a coarse fabric, their surface is uneven both on the exterior and interior, and they have a greyish, mottled exterior and reddish interior. Their ornamentation generally consists of alternating lugs set in two rows.

\subsection{Unusual vessels (T11)}

This category is made up of vessels with attributes that differ to some extent from the forms typical for one or another main type (Fig. 15). Two vessels resemble the size and proportions of dishes (Fig. 32.7; Fig. 56.1), one of bowls (Fig. 40.6) and one of conical vessels (Fig. 48.6). Their shared attribute is an angular form that makes their overall appearance rather unusual. ${ }^{84}$

The two dishes have small impressed knobs on their rims at the corners ${ }^{85}$ and lug handles on opposite sides, conforming to the attributes of the original type. The smaller vessel is fragmentary (Fig. 56.1) and could only be partially reconstructed. The larger one was found in a near-intact condition among the vessels deposited in front of House 5. The knobs set on the four corners were modelled in the shape of inward looking animal heads. One side of the vessel is pierced by four round perforations (Fig. 32.7), which relates it to a unique vessel type of the ALPC. ${ }^{86}$

While comparable pieces to the angular (rectangular) deep bowl with slightly curved sides can be found in the ceramic material from the Late Neolithic tells of the Hungarian Plain, these are without exception described as exceptional, unusual vessels. ${ }^{87}$ The vessel's trapezoidal sides bear incised panels filled with meander designs (Fig. 40.6).

79 Szegvár-Tüzköves (Korek 1987, Tab. XLVII. 6).

80 RACZKy 1987, Fig. 28.

81 Battonya-Gödrösök (Goldman 1984, Tab. 24. 1-3), Hódmezővásárhely-Kökénydomb (BANner 1930, Tab. XXXI. 1).

82 Berettyóújfalu-Herpály (KALICZ - RACZKy 1987b, Fig. 11).

83 Battonya-Gödrösök (Goldman 1984, Tab. 19. 1), Berettyóújfalu-Herpály (Kalicz - Raczky 1987b, Fig. 10), Hódmezővásárhely-Kökénydomb (BANNER - KOREK 1949, Tab. 1. 7).

84 Banner 1930, Tab. XXXI. 2; Hegedüs - Makkay 1987, Figs 12-13; Raczky 1987, 76.

85 Vésztő-Mágor (Hegedűs - MAKKAY 1987, Fig. 11).

86 Hajdú - NAgy 2015; Makkay 1963, 7, Tab. I; Tab. II. 6; Tab. VIII.

87 Berettyóújfalu-Herpály (KALICZ - RACZKy 1987b, 181), Vésztő-Mágor (HEGEdűs - MAKkAY 1987, Figs 135, 144). 


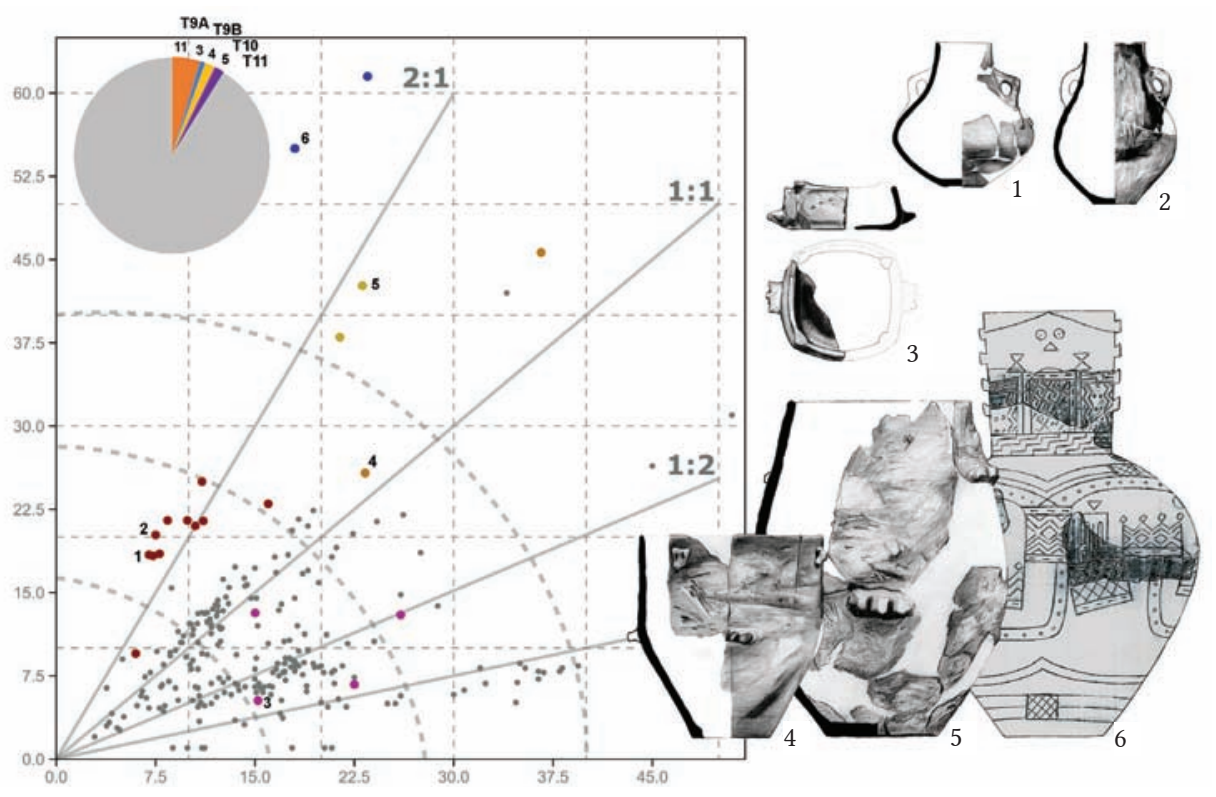

Fig. 15. Distribution of various vessels and their main types based on the metric data. 1-2 - Jugs (T9A), 3 - unusual vessels (T11), 4-5 - storage jars (T10), 6 - amphoras (T9B). The pie chart shows the number of these vessels among the refitted vessels.

The section of the fourth vessel differs at the rim and the base; these so-called shape-shifting vessels were particularly widespread on the northern Hungarian Plain during the Late $\mathrm{Ne}-$ olithic, where they hark back to local Middle Neolithic precursors. ${ }^{88}$ The short sides of the Ócsöd vessel are rectangular, while the long sides are curved. The two short sides are pierced by three round perforations under the rim (Fig. 48.6).

One peculiar vessel can be assigned to conical bowls in view of its upper part; however, the tall, fenestrated pedestal and the flat disc-like base set it apart from the other bowls brought to light on the site (Fig. 63.6). It stands out from among the other finds not only because of its form, but also owing to its red- and yellow-painted patterns. The bowl's rim is peaked and perforated in four spots, while the disc-shaped base is decorated with concentric circular channelling and small double knobs set opposite each other on the base of the fenestrations. ${ }^{89}$

Another unusual vessel is represented by an anthropomorphic vessel modelled in the shape of a sitting female figure from the settlement's late period. ${ }^{90}$ The woman is seated on a rectangular throne, her hands resting on the legs. An applied element imitating a Spondylus bracelet graces her upper arm. The breasts are marked with small knobs, underneath which is a vertical band filled with a geometric pattern. The back is decorated with a meander design set in a triangular field combined with a comb-motif. ${ }^{91}$ The lower part of the body bears a chequerboard pattern (Fig. 53). Several fragments of similar anthropomorphic vessels can be found in the ceramic inventory of the Öcsöd site. ${ }^{92}$

Sево̋к 2007, 104-106, Fig. 3. 23, 26-27.

For a detailed discussion of this vessel, cf. RACZKy - FÜZESI 2018, 147-148.

Hódmezővásárhely-Kökénydomb, Venuses I-III (KALICZ - RAcZKy 1987a, Figs 2-5), Vésztő-Mágor (HEGEDŰs MAKKAY 1987, Figs 9-10).

1 The comb motif is a typical decorative element on the face pots of the Middle Neolithic (SEBőK - KovÁcs 2009, 85-86, Fig. 2. 1-2).

RACZKY 1987, Figs 33-35. 


\subsection{Lids}

\section{(a) Conical lids (T12A)}

The assemblage discussed here comprises nine conical lids (Fig. 34.1, 3; Fig. 37.4; Fig. 44.2, 3; Fig. 45.5; Fig. 46.1; Fig. 48.4; Fig. 55.4), most of which fall into the small- and medium-sized category (S2-3), although a miniature exemplar can also be found among them (Fig. 16). The smaller ones have a diameter of $9 \mathrm{~cm}$, the larger ones range between 14 and $19 \mathrm{~cm}$. Two smaller lids (Fig. 34.1,3) and a larger one (Fig. 44.3) can be found among the taller exemplars. The low lids are dominated by the variant with curved sides (Fig. 44.2; Fig. 45.5; Fig. 48.4; Fig. 55.4) as contrasted with the variety having straight sides (Fig. 37. 4). The modelling and the fabric of these vessels are of medium quality, their surface is generally smoothed on both sides, while two lids are polished. One vessel with an uneven, unsmoothed surface retained traces of red pastose painting in its interior (Fig. 34.3). Lids generally have a reddish-grey colour with mottling on both sides, reflecting heat effects during their use. A greyish-black concentric discolouration can be noted around the lower edge, most likely the imprint of the vessel rim that the lid had covered.

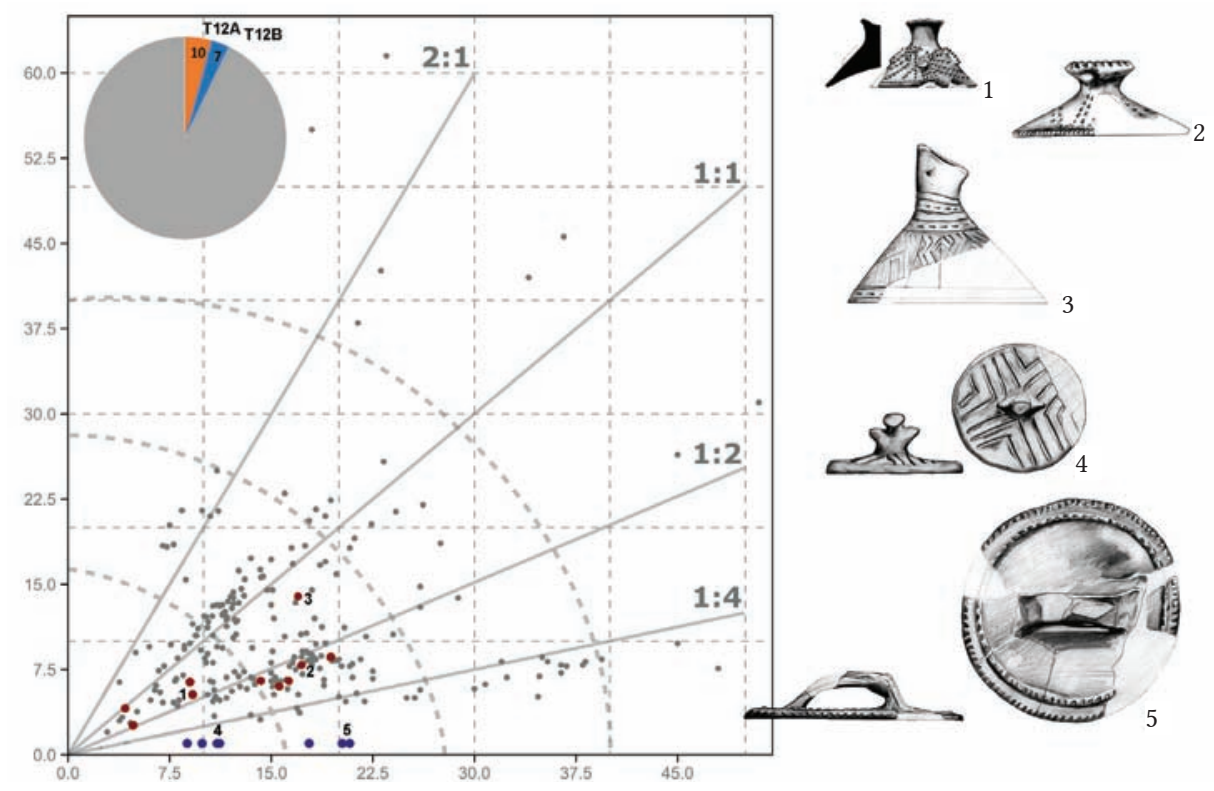

Fig. 16. Distribution of lids according to their main types based on the metric data. 1-3 - Conical lids (T12A), 4-5 - flat lids (T12B). The pie chart shows the number of lids among the refitted vessels.

The knobs are fairly simple compared to the ones on lids from the Late Neolithic sites on the northern Hungarian Plain..$^{93}$ The most frequent forms are the low conical variants that are usually plain, although two exemplars have an impressed rim (Fig. 34.1; Fig. 37.4). ${ }^{94}$ The cylindrical knob with rectangular section differs from the former (Fig. 48.4). A larger tall lid has a fairly unusual knob (Fig. 44.3): the cup-shaped knob is modelled in the shape of a head with oblique top and an oval, slightly spindle-shaped mouth. The two small knobs on the two sides were perhaps intended to represent stylised eyes or ears. ${ }^{95} \mathrm{~A}$ smaller lid of similar shape

93 Cf. Katalin Sebők’s selection of the lids from Polgár-Csőszhalom (SЕвőк 2007, 102-104, Fig. 2. 1-26).

94 Sево̋к 2009, Type L2; Szegvár-Tűzköves (KoREK 1987, Fig. 10), Vésztő-Mágor (HEgEdűs - MAKкAY 1987, Fig. 21).

95 Vésztő-Mágor (HEgEdűs - MAKKay 1987, Fig. 16). 
(Fig. 34.3) has a broken knob, whose surviving portion (an oval knob with an oblique impression) suggests that it had perhaps had an anthropomorphic/zoomorphic modelling resembling the previous one.

The lids include plain exemplars (Fig. 48.4), pieces decorated with a simple pointed knob (Fig. 55.4), a W-shaped impressed rib (Fig. 44.2) and bands of short stabs (Fig. 34.1; Fig. 37.4; Fig. 45.5). Incised patterns can be seen on three lids representing the taller variety. The miniature lid has a simple zig-zag line encircling the body (Fig. 34.1), the medium-sized piece is decorated with a chequerboard pattern of hatched squares (Fig. 34.3), which appears to have been botched owing to the asymmetrical division of the vessel surface as well as other small signs. The larger lid with anthropomorphic knob is decorated with a meander design arranged in panels (Fig. 44.3).

(b) Flat lids (T12B)

The assemblage comprises seven flat lids (Fig. 32.5; Fig. 38.1; Fig. 39.4; Fig. 40.1; Fig. 42.1; Fig. 44.1; Fig. 61.8), whose sizes resemble those of the conical type (Fig. 16). ${ }^{96}$ The smaller ones have a diameter of $8.5-11.5 \mathrm{~cm}$, the larger ones of $17-21 \mathrm{~cm}$. These lids are simple flat discs with the exception of a single slightly convex exemplar (Fig. 39.4). The treatment of the lids is similar to the previous ones, although the proportion of smoothed and unsmoothed pieces is roughly identical in this group. Their exterior is red or grey, and traces of secondary burning could only be noted on three exemplars. The interiors are generally brownish-grey with mottling.

Knobs are more varied compared to the previous type. Large loop handles (Fig. 40.1) and strap handles (Fig. 32.5) occur alongside small suspension lugs set opposite each other (Fig. 39.4). ${ }^{97}$ Modelled knobs can be found on two lids: one resembles a large flat scalloped ledge handle (Fig. 44.1), the other has anthropomorphic traits and is modelled in the shape of a human upper body with flat, upward-looking face and outspread arms (Fig. 61.8).

The smallest piece among the flat lids is plain (Fig. 44.1), while the largest exemplar has an impressed rim and an impressed cordon running parallel to the rim (Fig. 32.5). The smaller lids decorated with an incised pattern usually feature simple designs based on cross and herringbone elements (Fig. 38.1; Fig. 39.4; Fig. 61.8). The two larger lids with incised decoration bear meander-based patterns: the meanders are arranged in panels on one (Fig. 42.1), and in a field bordered by the handle and special decorative elements on the other (Fig. 40.1). ${ }^{98}$

\section{The reconstruction of the vessel types and of the vessel set}

\subsection{The relation between form and function}

The vessel types distinguished on the basis of formal and metric criteria do not necessarily coincide with the categories distinguished by the one-time community using these vessels: ${ }^{99}$ the concept of functional vessel types has been proposed to resolve this inconsistency. Scholarly opinions vary regarding the relation between form and function: some archaeologists argue

SEвőк 2009, Type L1; Battonya-Gödrösök (Goldman 1984, Tab. 37. 1-14; Tab. 38. 8-9), BerettyóújfaluHerpály (KAlicz et al. 2011, 37, Fig. 2), Hódmezővásárhely-Kökénydomb (BAnner 1930, Tab. VII. 2), Szegvár-Tüzköves (KoREK 1987, Fig. 9).

97 Szegvár-Tüzköves (KoneK 1973, Tab. XLV. 1-6).

98 For a detailed discussion, cf. RACZKY - FÜZESI 2018, 149-150.

99 RICE 1987, 274-275. 
for a close correlation between the two. ${ }^{100} \mathrm{~A}$ morphofunctional relationship denotes a close systemic relation between technology, form and function, in which each of these constituents changes in different ways and at a different pace. ${ }^{101}$ Other scholars argue for a link between form and function, citing a functional determinism essentially defined by form. Certain traits determine the nature and potentials of function insofar as efficiency is taken as a starting point in the choice of function. ${ }^{102}$ The more sceptical approach highlights the colourful diversity in correlations between form and function ${ }^{103}$ as well as the freedom of cultural choices in selecting vessel functions, while acknowledging the laws of physics. ${ }^{104}$

The identification of the original function(s) of vessels in the case of archaeological assemblages is hardly without its problems. We can gather a wealth of additional information about the finds, which provide further details regarding the three-dimensional world of sizes and forms. Fabric, colour, surface treatment, the nature and extent of ornamentation as well as possible traces of use-wear offer additional clues regarding one-time function and use. ${ }^{105}$ These complementary attributes were described for each formal type in the analysed ceramic assemblage in the previous section (Appendix 1).

The interpretative framework of the functional reconstruction is provided by the overview and categorisation of potential functions. While the methodology of formal classifications was elaborated in detail by the mid-twentieth century, ${ }^{106}$ far less attention was devoted to the identification of function. Scholars engaged in the study of archaeological ceramics constructed several models based on cultural anthropological and ethnographic research, among which one of the first was proposed by Hilary Howard. ${ }^{107}$ The first overall abstract system, still employed by archaeologists today, was created by Prudence M. Rice. Her functional system distinguished three main functions: storage, processing and transfer, with sub-groups based on the duration of storage, whether there was any heat effect during processing, the distance of transfer, whether the contents were liquid or dry, or hot or cold. Her hierarchical model also contained functions that were not fulfilled by ceramic vessels, but in some other manner. ${ }^{108}$

The third pillar of identifying function rests on ethnographic data. ${ }^{109}$ Handbooks on archaeological ceramics generally devote a separate section to this source of information. Very often, the relevant data of as many as ten to thirteen population groups are compared in cultural anthropological studies. ${ }^{110}$ The threefold division of cooking, serving and storage is generally employed in descriptions of vessel functions. ${ }^{111}$ Cultural anthropological studies have demonstrated not only the hierarchic nature of the vessel sets used by various communities, but also their specific and contextual nature. In an early study on this subject, Keith Nicklin analysed the pottery of the Ibibio group. He identified three main functional groups (contain-

100 SinOPOLI 1991, 84-85.

101 Rice 1987, 464; SANTACREU et al. 2017, 189.

102 SAntacreu et al. 2017, 189.

103 KNOpF 2009, 6; Rice 1987, 211-212.

104 HodDER 1981, 215.

105 For the use of these attributes in the identification of functional groups, cf. HowArd 1981; HuNT $2017,6$.

106 ShePARD 1956/1995, 225-236.

107 Howard 1981, 8-10, Tab. 1.1.

108 Rice 1987, 208-210, Fig. 7.1.

109 PEACOCK 1981.

110 Rice 1987, 293-299; Sinopoli 1991, 71-74.

111 Rice 1987, Tab. 9.4; Sinopoli 1991, Tab. 5.1-2. 
ers, serving-washing bowls, cooking-processing pots), alongside a more detailed classification. He distinguished nineteen categories within the three groups, whose attributes included criteria such as vessels for various types of liquids (drinking water, water to "cool" the soul, communal drinking of wine) and vessels for sacrifices and major sacrifices ${ }^{112}$ It follows from the above that each vessel set has to be assessed and interpreted within its own context and association. ${ }^{113}$

Archaeometric analyses represent the fourth, and probably most reliable method for determining vessel function. Advances in this field have resulted in a wide range of analytical procedures, ${ }^{114}$ even though this does not always mean that they can be successfully applied.

Other aspects also need to be considered in reconstructing vessel function. One important step in identification is the very designation of the artefact type. It has been repeatedly pointed out that the labels used by archaeologists are not neutral and that even though they denote formal categories, they often have strong functional implications (e.g. pot, bowl, cup). ${ }^{115}$ This, in turn, can distort interpretation not only because of the biased nature of identification, but also because it emphasises one particular function, even though a vessel could have been used in many ways: for example, jugs and amphoras suitable for storing liquids were also suitable for transportation, while smaller vessels such as undecorated conical bowls and dishes in which food was prepared could also have been used for consuming the meal. ${ }^{116}$ The diversity of vessel forms does not necessarily imply a diversity of function. The formal richness or poorness of the vessel sets used by a community cannot be principally and exclusively be derived from its social relations, but needs to be analysed in their complexity. Any analysis must specifically address the social significance of the functions of the given vessel types (such as eating and drinking). ${ }^{117}$

\subsection{The vessel sets of Öcsöd-Kováshalom}

We undertook the functional reconstruction of the refitted and reconstructed vessels from Öcsöd-Kováshalom in line with above-discussed methodological and theoretical considerations, as well as our previous studies (Figs 17-21). ${ }^{118}$ In essence, we followed Rice's system, setting up the categories of consumption, processing and storage, within which we distinguished smaller units based on heat utilisation and the consistence of the treated food material. We could distinguish a group serving purposes of social display based on the extensive ornamentation within the types ordered according to this principle. The vessels serving ritual purposes $^{119}$ comprise those vessels of unusual form, ornamentation and context, which were unique not only in terms of the Öcsöd site, but also within the Late Neolithic of the Hungarian Plain.

112 NiCKLIN 1981, 177-178, Fig. 10.2.

113 HODDER 1981, 215.

114 Hunt 2017, 5, Tab. 1.1, 585-647.

115 KNOPF 2009, 5.

116 Rice 1987, 209.

117 "Pottery must be understood not as pottery, but within its own context. In some stable and relatively complex societies pottery is not produced or it is scarce and crudely made. In some simple and small-scale societies pottery production is highly developed and the forms produced are rich and numerous. Such variation may partly relate to the symbolism associated with food, drink and to whether consumables and eating are given symbolic significance."(HODDER 1981, 219).

118 FÜZESI 2016, 380-382, Figs 10, 12; RACZKY - FÜZESI 2016b; RACZKY - FÜZESI - ANDERs in press; RACZKY et al. in press, Figs 15-16.

119 PechtL 2015. 
T1A

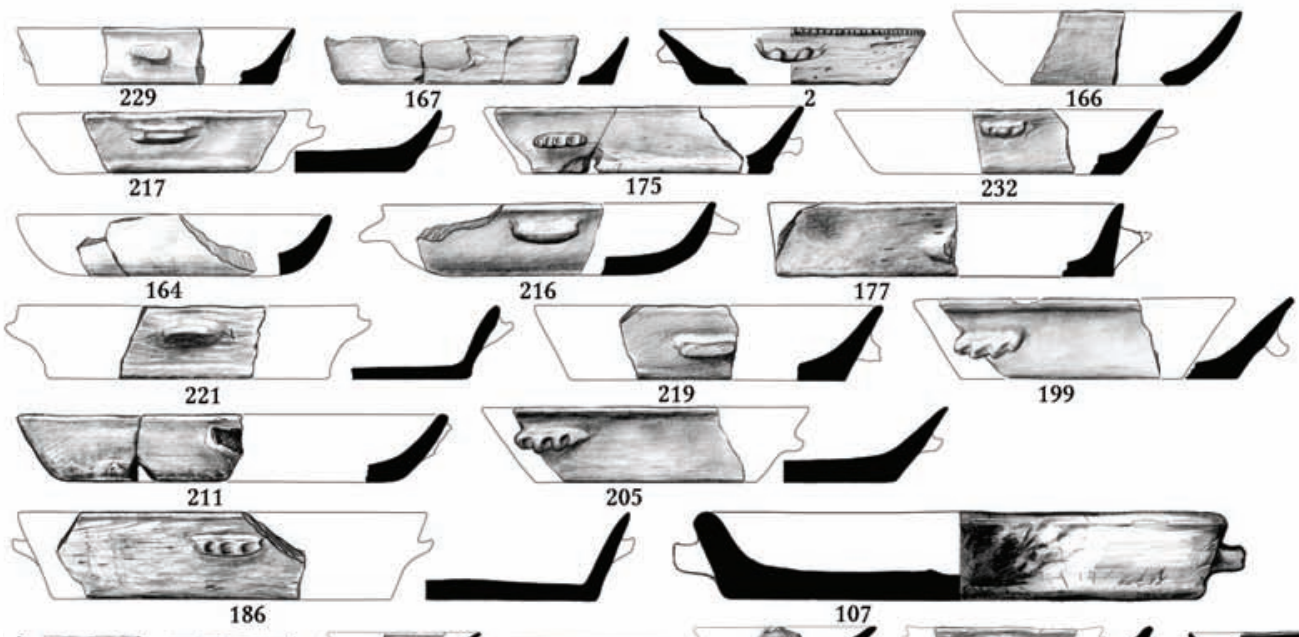

T1B

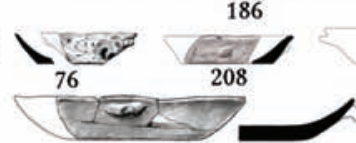

$\mathrm{T} 1 \mathrm{C}$
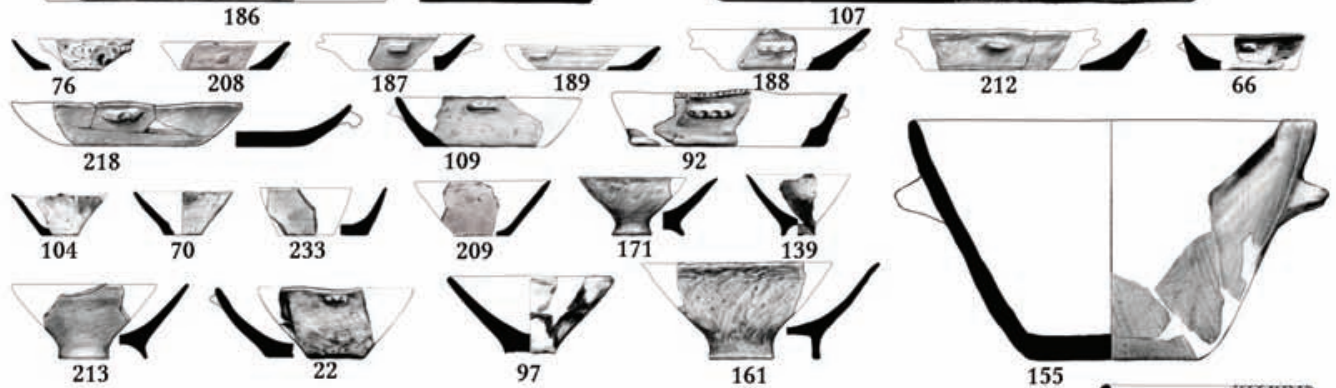

T1D
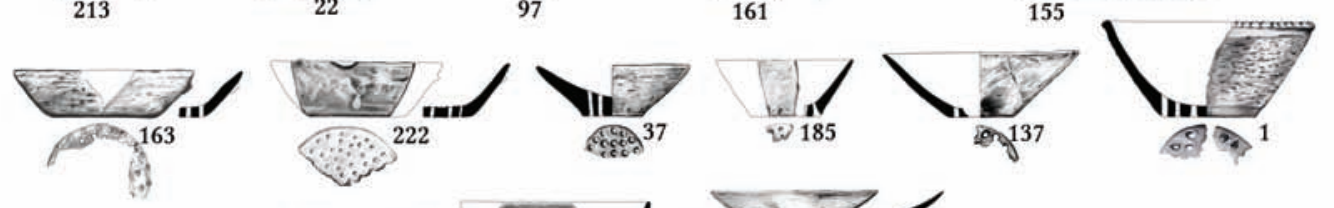

$\mathrm{T} 2$

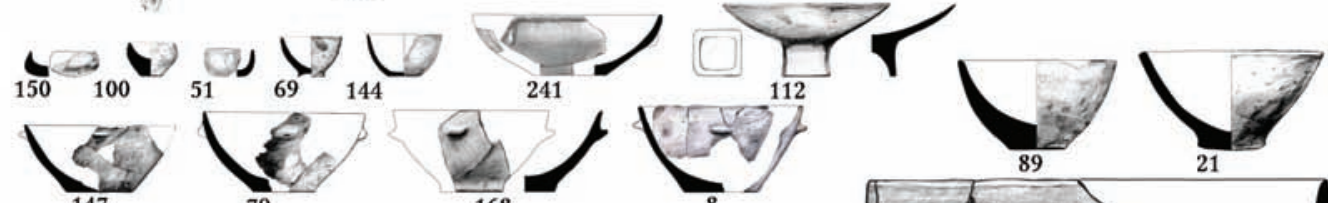

T3A
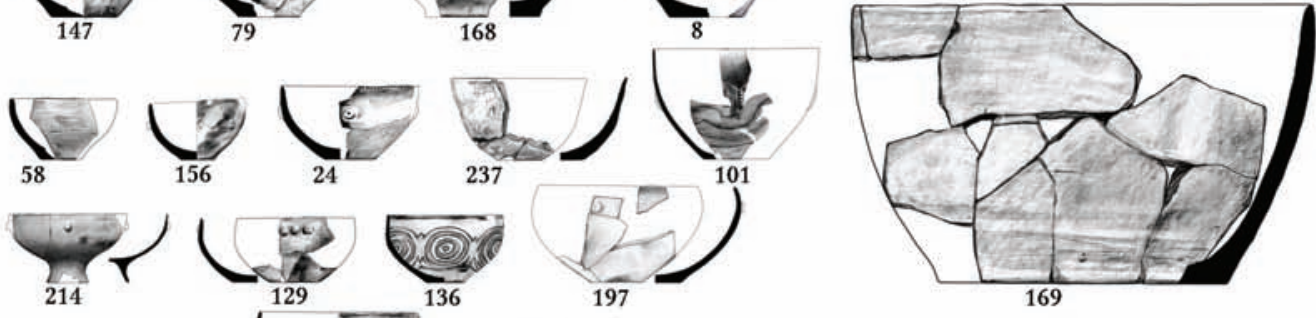

Fig. 17. The vessel set of Öcsöd-Kováshalom. Plates, dishes, conical and spherical bowls.

The diagram summarising our results (Fig. 22) shows not only the breakdown of the refitted vessels according to type, but also the differences in the number of vessel forms associated with a particular function. The assemblage is dominated by vessels associated with consumption (65.4\%). Their formal diversity is also quite unique: open forms (bowls) are represented by five types, closed forms (cups and small vessels) by four types. This distribution can be regarded as being proportionate, inasmuch open forms account for $51.4 \%$ and closed ones for $41.3 \%$. Vessels associated with processing represent $23.7 \%$. Formal variations among the vessels assigned to this category can only be noted among pots (three types). A basic storage function could only be established in the case of six vessels, accounting for $2.5 \%$. Lids occurring in higher number could be used in both processing and storage (6.7\%) and thus if they are 
added to the vessels used in processing, the latter make up 30\%, while if added to the vessels used for storage, these still remain below $10 \%$. The proportion of vessels possibly used for ritual purposes is no more than $1.7 \%$. We distinguished types associated with fire (heat) and water (liquids) in the assessment of vessel function. The proportion of pots used in operations associated with heat was $10 \%$ within the entire assemblage and $42.8 \%$ within the group. The proportion of closed vessels in the group associated with consumption was $13.5 \%$. If the large amphoras and strainer vessels as well as the shallow bowl with perforations on one side from among the ritual vessels are also included, the number of vessels in this category rises to $41(17.3 \%)$. Vessels that can be linked to usage as part of social display are covered with a distinctive, rich ornamentation. Most of these are vessels falling into the category of closed vessels used in consumption (T6 and T7, and partly T4 and T5), accounting for $15 \%$.

T3B
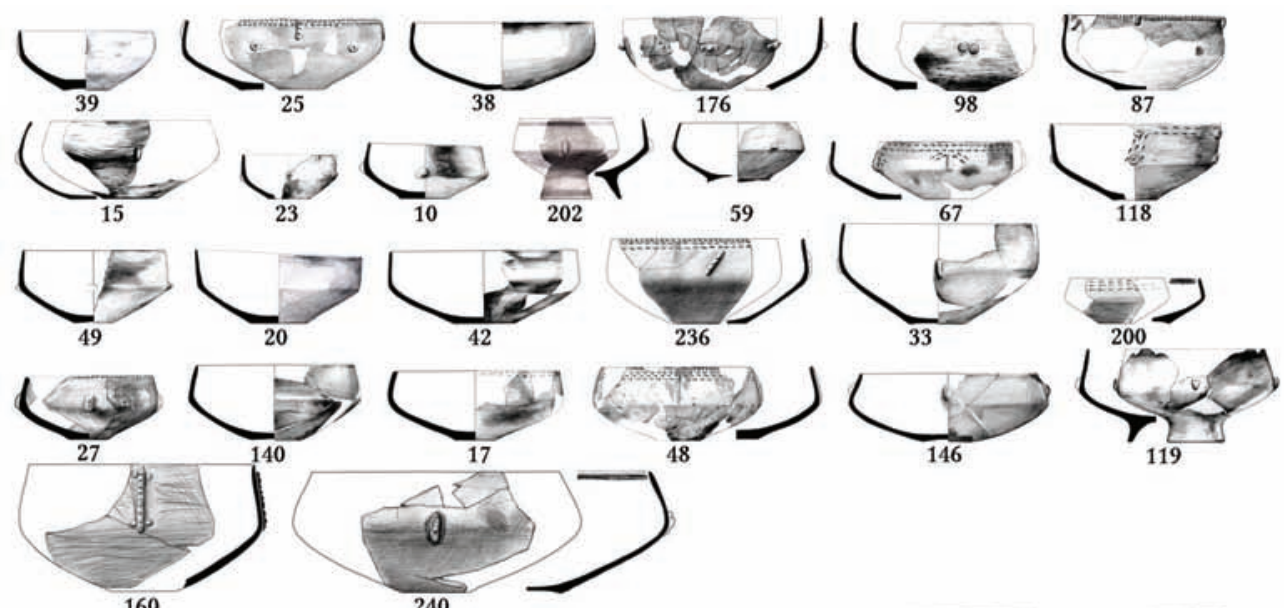

$\mathrm{T} 3 \mathrm{C}$
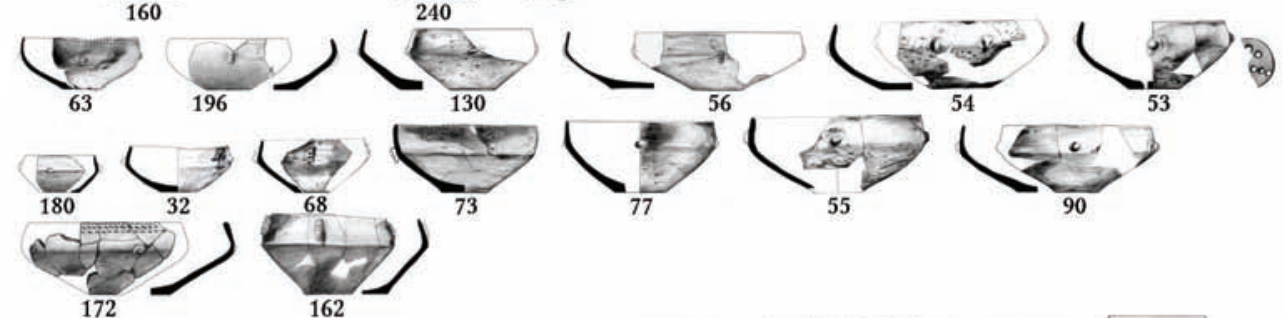

$\mathrm{T} 4$
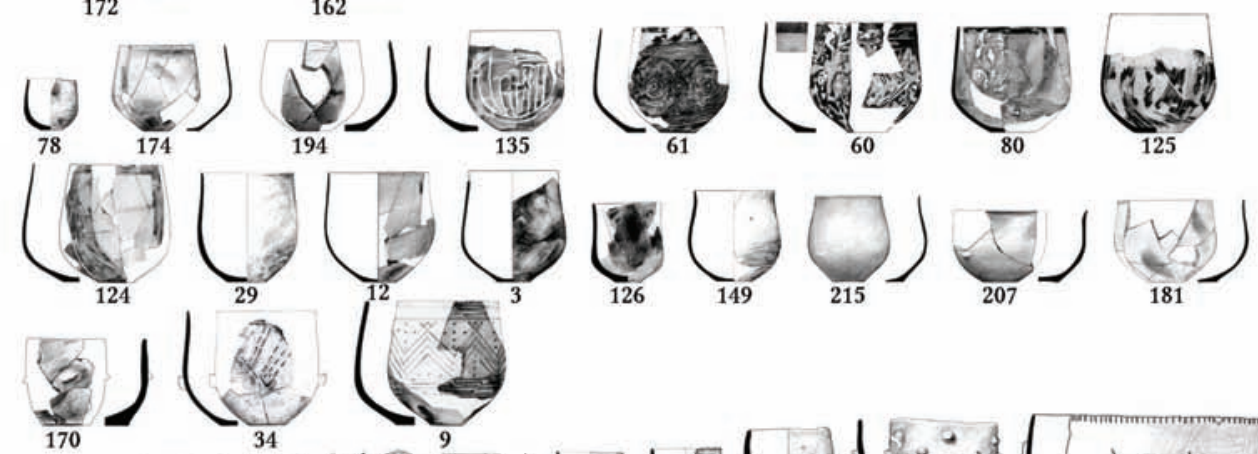

T5

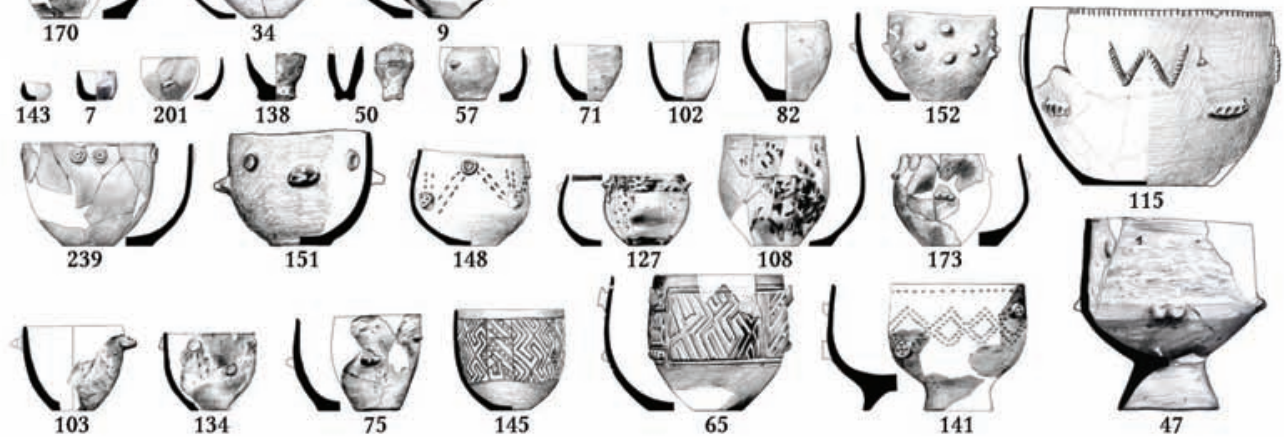

Fig. 18. The vessel set of Öcsöd-Kováshalom. Biconical bowls, cups and vessels with curved sides. 

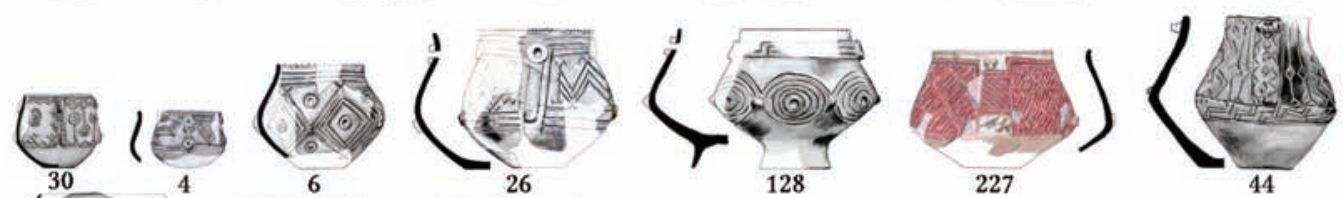

T7
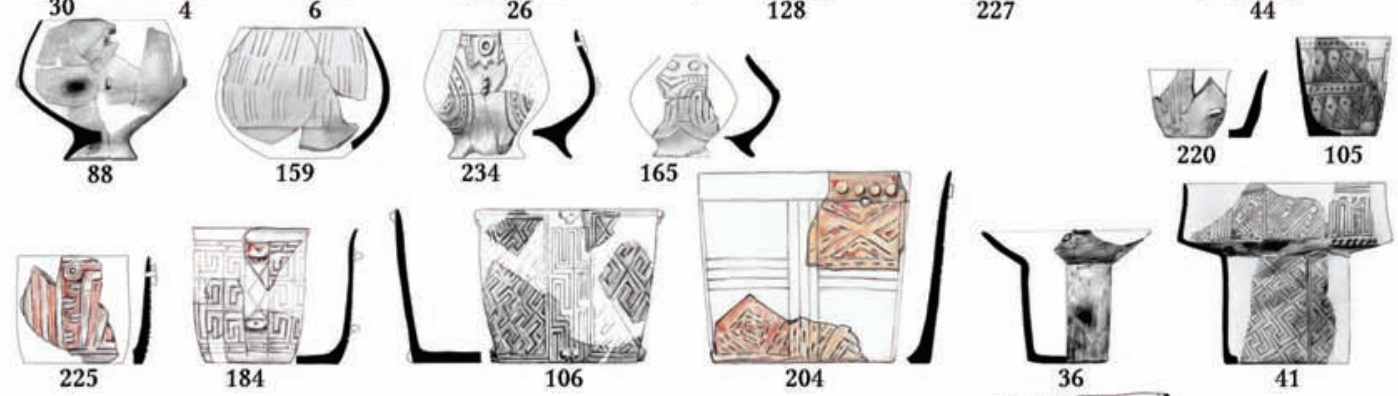

T8A
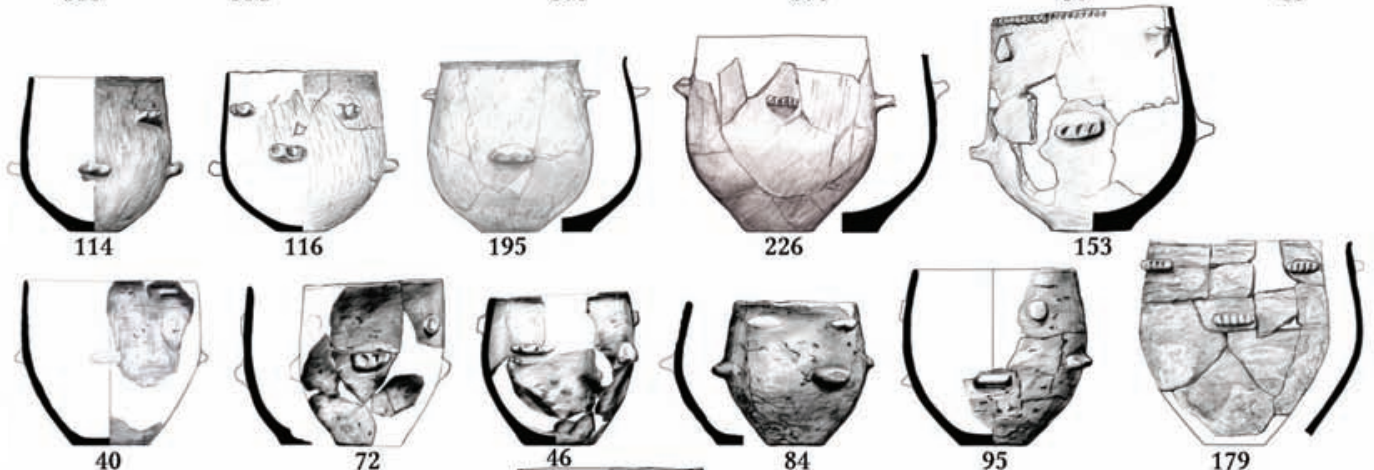

$\mathrm{T} 8 \mathrm{~B}$
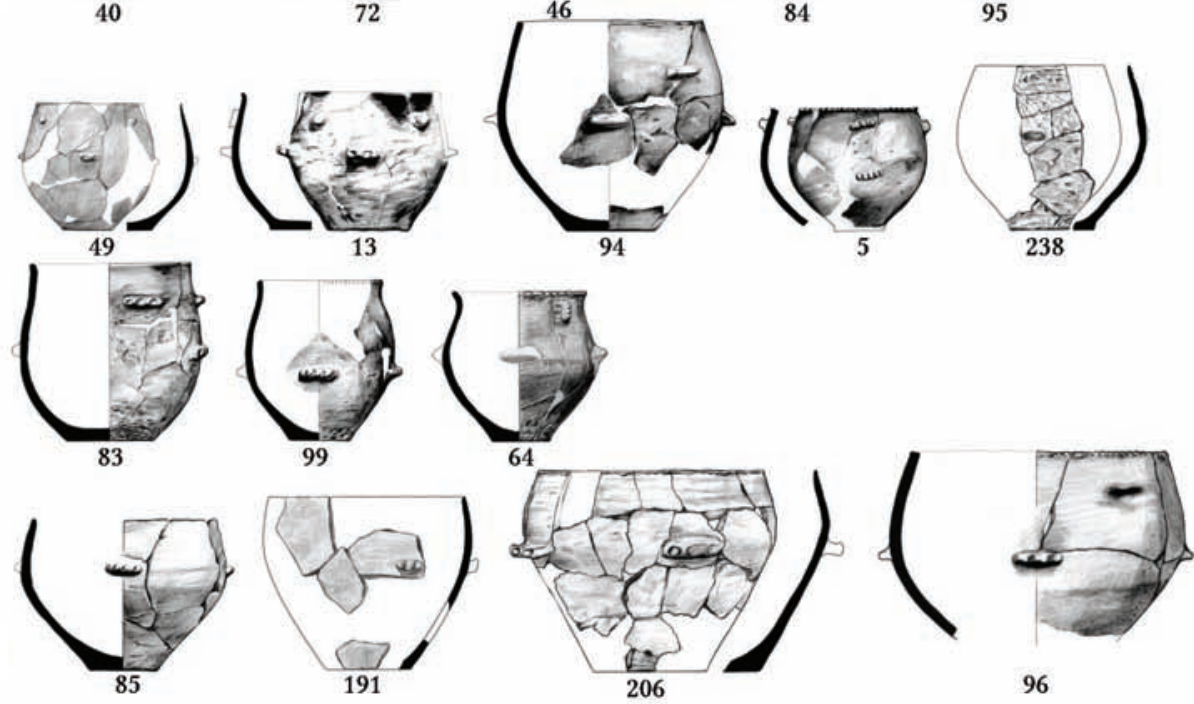

Fig. 19. The vessel set of Öcsöd-Kováshalom. Biconical and conical vessels and pots.

\subsection{Correction of the data}

A comparison with other data seems in order in the assessment of the composition of the ceramic assemblage from Öcsöd. The classification of the vessels according to their proportions (P1-4) and their sizes (S1-5) yields different results regarding the composition of the vessel. While the proportion of open and closed vessels relative to each other can be accepted as being accurate regarding the entire ceramic inventory from the site, the assemblage of refitted and reconstructed vessels provides a strongly distorted picture in terms of size categories. A similar observation can be made for other sites too. We compared the data published in two final reports of Late Neolithic sites. One of these is the 1957 sounding at Polgár-Csőszhalom, published by Eszter Bánffy. The greater part of the assemblage of 1734 ceramics was 
fragmented; no more than 33 vessel profiles could be reconstructed, of which nine vessels fell into the medium or larger size categories. ${ }^{120}$ The material recovered from the Kammeg enclosure in Lower Austria dated to the Middle Neolithic was published by Michael Doneus. There were 52 complete vessel profiles among the over 1500 pottery fragments from the site, of which fourteen were medium-sized or larger. ${ }^{121}$ There is a greater likelihood for reconstructing vessels falling into the smaller size categories owing to the fragmentation and the size of the vessel profile than the larger vessels, and the chances for reconstruction are also influenced by the different purposes for which various vessels were used.

T9A
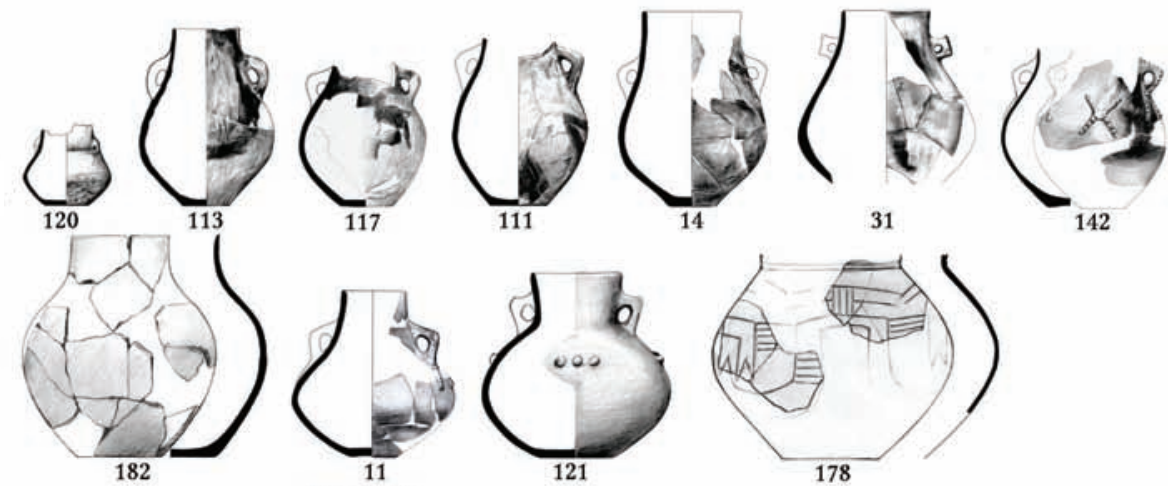

T9B
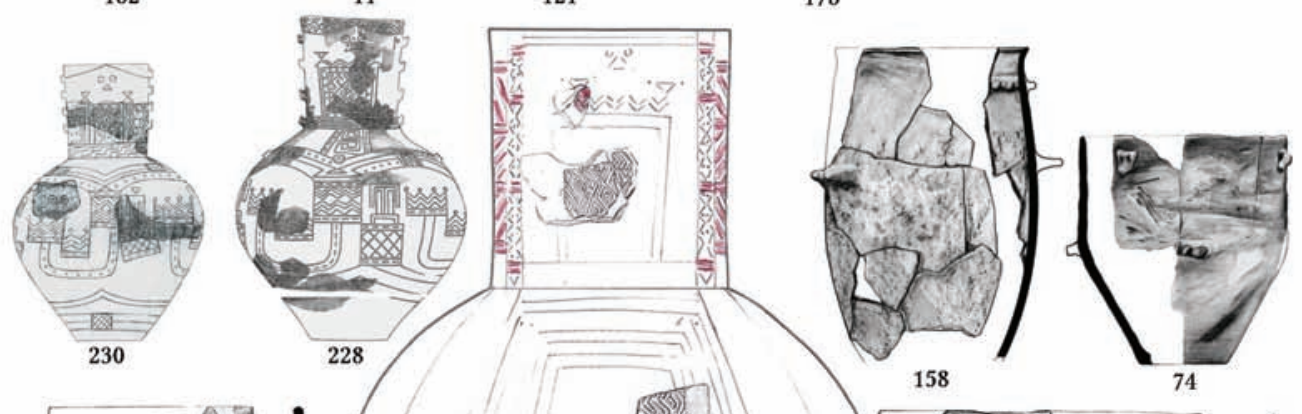

$\mathrm{T} 10$

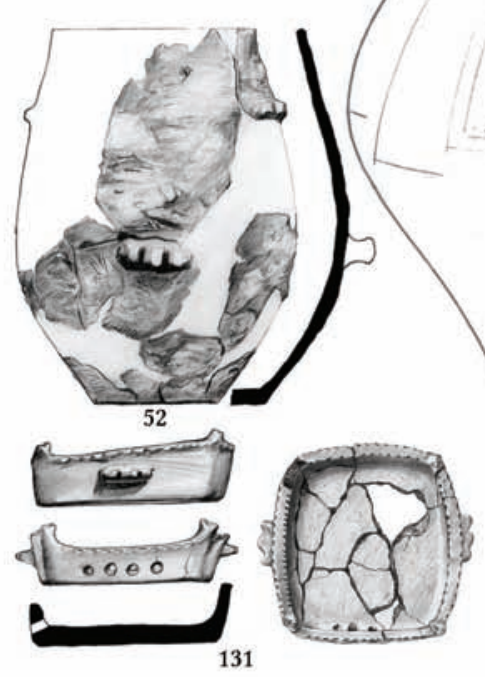

T11
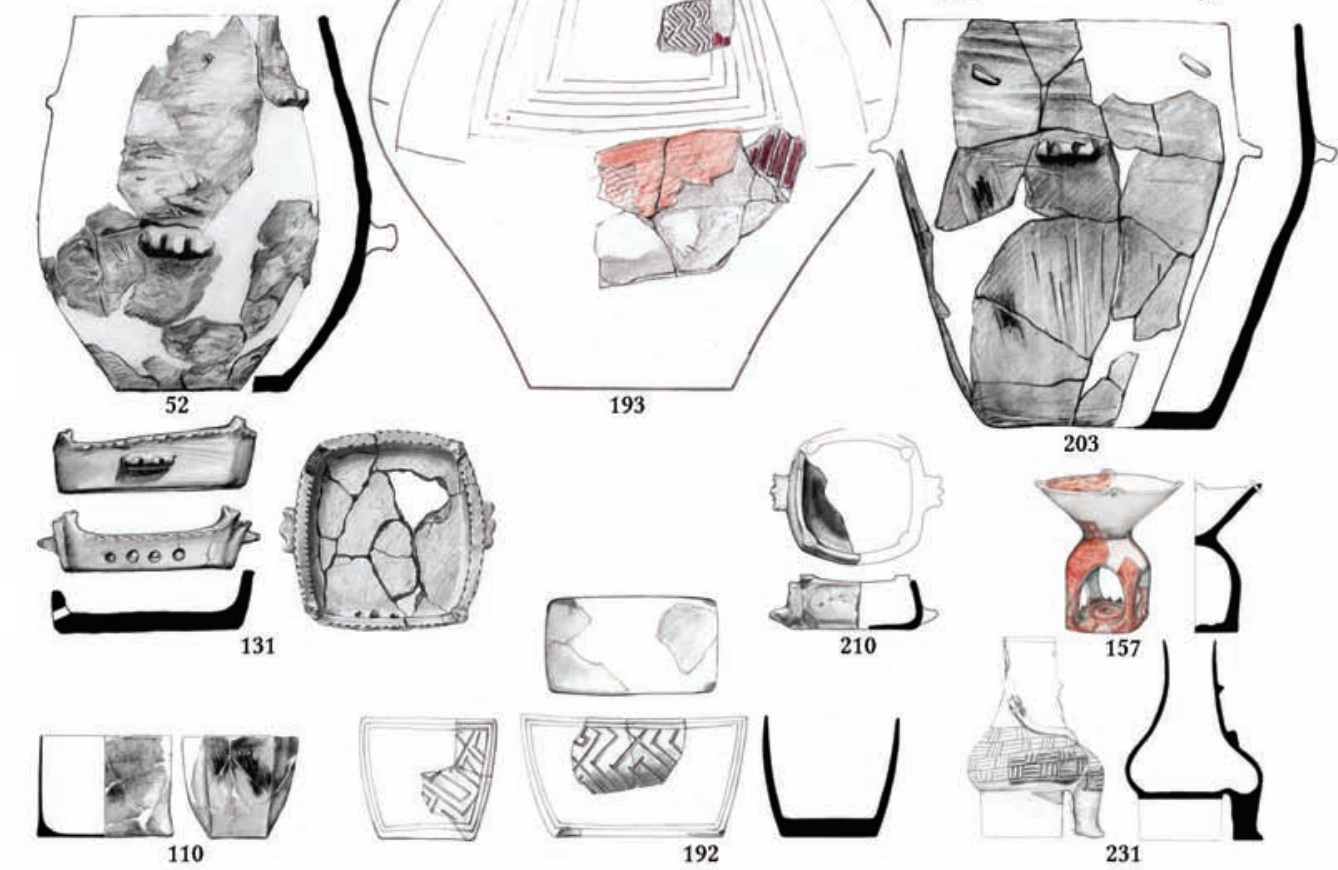

Fig. 20. The vessel set of Öcsöd-Kováshalom. Jugs, amphoras, storage jars and unusual vessels.

120 BÁNFFy - BognÁR-KutZiÁN 2007.

121 Doneus 2001. 
T12A
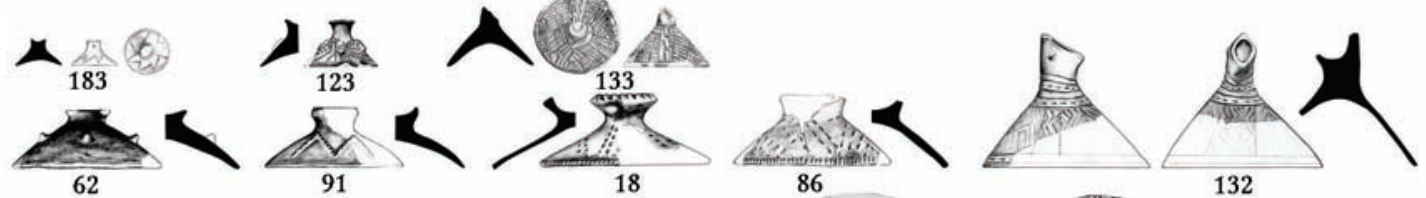

T12B
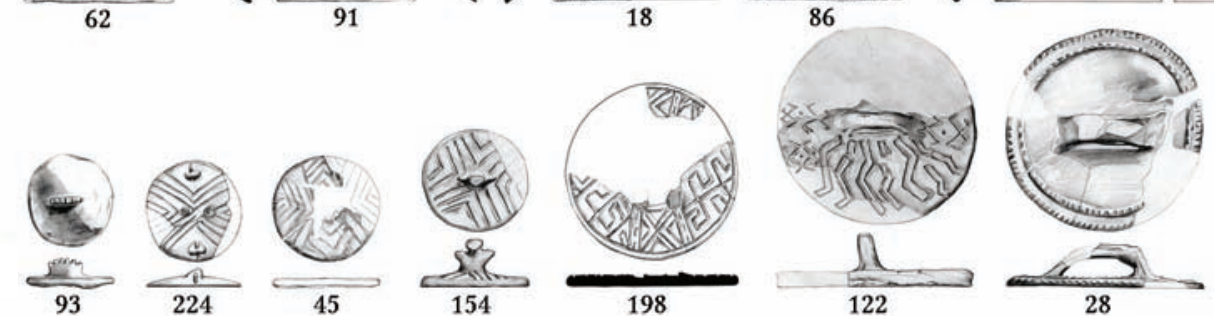

Fig. 21. The vessel set of Öcsöd-Kováshalom. Conical and flat lids.

In order to determine the distortions deriving from refitting and restoration, we used the data record of the entire ceramic assemblage, in which the occurrence of three vessels types (storage jars, strainers and lids) was recorded separately. A total of 491 storage jar fragments, ${ }^{122} 115$ strainer fragments and 372 lid fragments were identified in the ceramic inventory, accounting for $0.6 \%, 0.1 \%$ and $0.5 \%$, respectively, and falling well below the percentages in the refitted assemblage (storage jars: $1.7 \%$, strainers: $2.5 \%$, lids: $6.7 \%$ ). In some cases (e.g. small lids), these differences can be attributed to the greater number of options in reconstruction: for example, in the case of lids, the smaller extent of fragmentation and the smaller vessel profiles, or the special context of a few finds (such as large face pots), are of aid in refitting and reconstruction owing to the concentration of the fragments. Nevertheless, the observations on pottery fragmentation and the distribution of the fragments only allows situational conclusions regarding the reconstruction of vessels and can hardly be applied universally.

We also turned to cultural anthropological studies for controlling our data for these do not merely describe the vessel set used by a community (often broken down to the household level), ${ }^{123}$ but also provide data regarding the use-life of individual vessel types. ${ }^{124}$ Although the size of the vessels set used in particular households varied, their composition reflected a more-or-less general tendency. Cooking pots (processing with heat) accounted for the greater part of the set, followed by food preparation vessels, among which eating and drinking vessels were represented in roughly equal proportion. The proportion of storage vessels was lower in each vessel category. The number of ritual vessels differed, but it never attained that of the first two groups.

In the course of our reconstruction, we also had to be mindful of the fact that archaeological assemblages usually condense long series of events into a single analytical unit, and thus any patterns we discern in them are the imprints of vessel sets used over a longer period of time and not of vessels used simultaneously. The data on the use-life of particular vessel types suggest different tendencies in the accumulation of discarded pottery. The use-life of bowls

122 The coarse, extremely thick-walled fragments representing the greatest size range were assigned to this category during the recording of the pottery, which corresponds to the group of amphoras and storage jars in our classification.

123 DeBoer - Lathrap 1979, 104-110, Fig. 4. 3; Howard 1981, Tab. 1.1; Rice 1987, Tab. 9.4; Sinopoli 1991, 88, Tab. 5.2; ArNold 1991, 62-68, Tab. 23.

124 David 1972; DeBoer - Lathrap 1979, 121-128, Fig. 4. 5, Tab. 4. 5; Rice 1987, 298, Fig. 9.4; Sinopoli 1991, 88, Tab. 5.1; Arnold 1991, 73-76, Tab. 27. 
and of small- and medium-sized cooking pots ranges between 2.5 and 3 years, while larger cooking pots and storage jars (with a volume over 15 litres) were used for over ten years on average. Nicholas David tabulated the distorting effect of the differential use-life of vessels relating to archaeological assemblages. ${ }^{125}$ According to his calculations, the original proportions in the case of more frequently replaced vessels resulted in a growth of $3-12 \%$ over a century, while the proportion of vessels used for a longer time in a decrease of 6-10\%. Applying this to the Öcsöd-Kováshalom assemblage (Fig. 22) offers two insights: the proportion of storage jars, ritual vessels and large-sized cooking pots calls for a roughly $10 \%$ correction, meaning that their proportion represents not one-third, but $40-45 \%$. At the same time, vessels directly associated with consumption account for the greater part of the vessel set. This figure does not correspond to the ethnographic data, which indicate the dominance of cooking vessels.

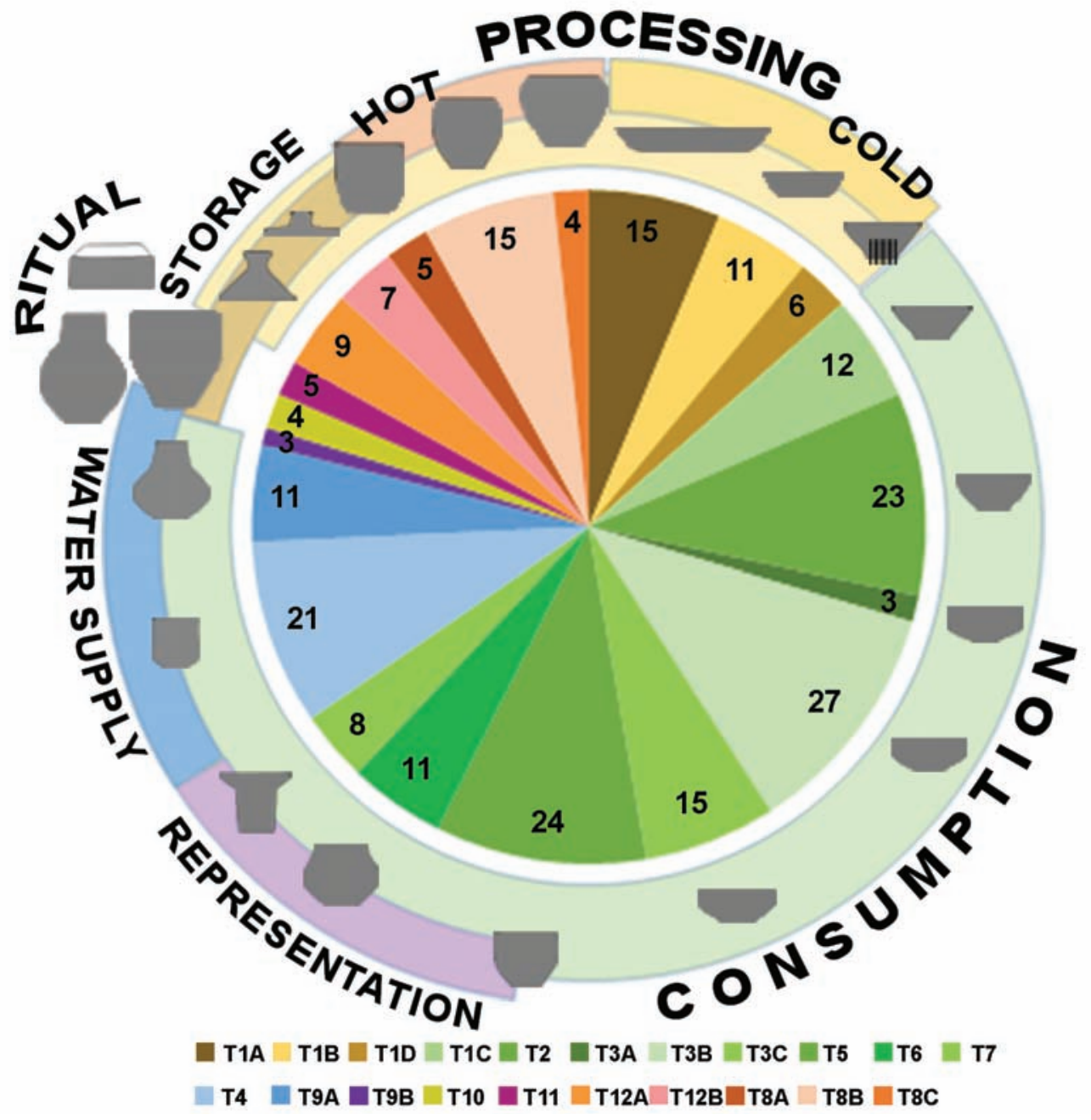

Fig. 22. Distribution of the main vessel types in the functional vessel set of Öcsöd-Kováshalom as reconstructed from the refitted vessels.

We used another dataset for estimating the proportion of fine wares associated with consumption. Although the find material was submitted to a post-excavation selective discarding procedure, the rim fragments were preserved and their ornamentation was recorded. $36 \%$ of all rims were decorated. Storage jars, amphoras and lids, which may also have included decorated pieces, were not included in this dataset. The proportion of rims with applied ornamen- 
tation typical for pots, plates and dishes was $9 \%$. The remaining ornamented rims (25\%) thus came from bowls, small-sized tableware, cups and jugs. Knowing that straw embedded in tar (9\%) was principally used for decorating cups, the $8.9 \%$ figure indicates the balanced presence of this vessel type. The remaining $18 \%$, made up of rims with painted or incised decoration, principally came from bowls (T1-3) and small vessels (T4-7). Thus, the fine ware used for consumption can be estimated as accounting for at least one-third of the entire set. This figure remains well below the estimate based on the use-life of various vessel types, but even so, it exceeds by far the figures provided by cultural anthropological studies.

The high proportion of ornamented vessels used for consumption at Öcsöd-Kováshalom is a reflection of a tendency in the use of ceramics particular to this site. This phenomenon will be discussed and interpreted in its own context ${ }^{126}$ and in the context of the cultural and social development of the Late Neolithic of the Hungarian Plain.

\section{Pottery ornamentation and the emergence of the Tisza style}

In addition to their primary utilitarian function, objects have many links with the other dimensions of life and participate in many forms of social interaction. ${ }^{127}$ The function of an artefact is determined by its form and other attributes, while the message conveyed by it is expressed through its ornamentation. These "messages" can be interpreted within the context of the visual idiom typical for a particular community, namely its style. ${ }^{128}$ Any understanding of style can only be set within a broader social context.

The three principal functions of style are as follows:

- to increase the stability of social relations and thereby decrease stress within the community,

- the reaffirmation of social differences with the growth of social complexity and the enhancement of in-group solidarity, and

- the expression and maintenance of boundaries between social groups. ${ }^{129}$

It can simultaneously express personal and group identities, depending on whether individual or group interests are at stake. The choice of employed style depends on to what extent it is able to communicate this relative identity. ${ }^{130}$

Design Structure Analysis is a good approach for studying style and its social role, involving three steps in the assessment of a style: the spatial division of the vessel surface (design spaces), the identification of ornamental elements and their configurations (patterns), and the position of individual elements with the patterns. ${ }^{131}$

\subsection{General tendencies in decoration types}

The number of ornamented vessels is high in the Öcsöd-Kováshalom assemblage, even if their proportion regarding specific types diverges significantly (Fig. 23). In the context of formal and functional types, the highest number of undecorated vessels can be found in the processing

126 HODDER 1981, 215.

127 HodDER 1981, 216.

128 RiCE 1987, 244-245.

129 RiCE 1987, 267.

130 Wiessner 1989, 56-58; PArkinson 2006, 36; Whittle 2009, 104.

131 RiCE 1987, 264-266. 
and storage group. The employed ornamental mode is almost exclusively restricted to applied decoration, which often had a primarily functional, rather than decorative role (e.g. ledge handles: Fig. 33.5; Fig. 40.4). Nevertheless, the arrangement of the applied elements on the pots can be regarded as the creation of an independent aesthetic category (Fig. 37.8; Fig. 39.1), ${ }^{132}$ as shown by the bands of short stabs connecting the alternating knobs set in two rows on small closed vessels (Fig. 33.9; Fig. 48.5) and the appearance of similar obliquely running bands of short stabs on conical lids (Fig. 37.4; Fig. 45.5). The most frequent ornamental technique was incision, which is virtually exclusive on small biconical and conical vessels as well as on amphoras in the refitted material, and is frequent on lids. Black-painted bands, red pastose painting covering the entire vessel surface and tar coating, often with straw inlay, can only be noted on a few vessels. The three decorative techniques appear independently on thirteen vessels, the single exception being pastose red painting, which was sometimes used to highlight incised designs on bowls (Fig. 31.3; Fig. 45.2), and on biconical (Fig. 51.1) and conical vessels (Fig. 46.2; Fig. 51.5, 6; Fig. 56.3), as well as on amphoras (Fig. 62.1). Different ornamental techniques occur on biconical bowls (T3B), cups and vessels with curved sides, associated with consumption.

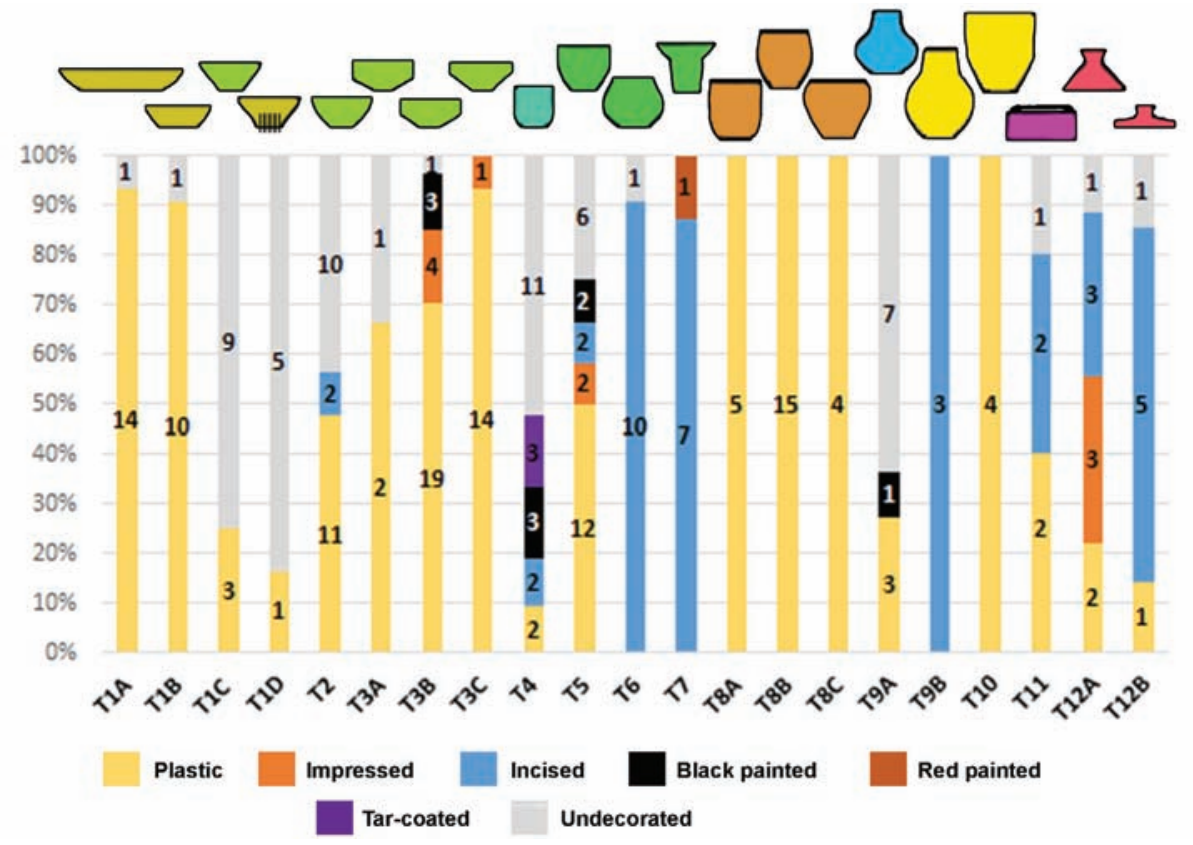

Fig. 23. The most important decorative techniques on the refitted vessels from Öcsöd-Kováshalom. The frequencies of each decorative technique (applied, impressed incised, black painted, red painted, tar-coated, undecorated) are shown according to vessel types. The colours of the icons representing the main vessel types correspond to the colours of the functional groups shown in Figure 17.

No more than $5-30 \%$ of the bowls used for consumption bears some decoration, while the same proportion among closed vessels (cups and conical and biconical vessels) ranges between $30-100 \%$. The differences can be attributed to the diverse visual properties of the two groups. ${ }^{133}$ The greater part of bowl surfaces is not visible, remaining unseen, and thus their

132 Applied knobs arranged in alternating rows appear on fine ware, too, as an independent ornamental scheme during the Tisza III period (RAczky 1992, Fig. 5. 3-8), for example at Berettyóúffalu-Herpály (Kalicz - Raczky 1987b, Fig. 21), Hódmezővásárhely-Gorzsa (GAzdApuszTAi 1969; Horváth 1987, Figs 10, 17) and Polgár-Csőszhalom (SEвőK 2007, Fig. 3. 5-6, 13).

133 Bowser - PAtton 2004, 176-177, Fig. 8. 
ornamentation concentrates on the prominent carination line and the zone under the rim. The former generally accommodates applied elements, the latter simple ornamental zones (usually bands of short stabs and black-painted bands: Fig. 30.8; Fig. 31.2; Fig. 33.3; Fig. 39.2; Fig. 46.5; Fig. 55.5). In contrast, the greater portion of tall closed vessels is visible, providing larger surfaces for elaborate, complex designs (Fig. 30.4; Fig. 31.1; Fig. 33.4; Fig. 34.4; Fig. 38.3; Fig. 42.5; Fig. 46.2). One indication of the importance attached to visibility is provided by lids, which had multiple functions during certain phases of processing and storage, and could also have been used in consumption. Their conical and flat surfaces provided large spaces for decorative schemes which were made good use of in $70 \%$ of the cases. Visibility of decorations was enhanced not only by form, but also by their position on the vessel surface during their use.

The vessels providing high visibility used in consumption would suggest that social display related to community feasting played a prominent role in social interaction. We also tested our assumption on the entire material. As part of the two correspondence analyses undertaken on the primary data of three vessel types (storage jars, strainers and lids), we also examined their formal and ornamental data. The formal attributes included handles and biconical sides, the ornamentation focused on technical attributes (incised, painted, tar coating and applied elements). We analysed the material from pits with closed context dug into the prehistoric soil and the material from the houses of the two horizons separately (Figs 24-25). The first organising principle (Axes 1 and 2) in the material from the pits was the clustering of ornamental techniques (Fig. 24.1). Vessel fragments with black-painted bands (B) differ significantly from ceramics with incised decoration and tar coating (A) in the case of both fine and coarse wares. The other dimension of the correspondence analysis (Axes 1 and 3) reflects the functional clusters of the vessel set (Fig. 24.2). Moving left to right, we find the storage jars, the strainers associated with processing and the handled vessels associated with liquids. Decorated vessels are clustered on the positive part of the $\mathrm{x}$ axis which, as indicated by other data (Fig. 23), were used during various phases of consumption. Finally, we find the lavishly decorated lids used in different positions. In order to clarify possible chronological issues, we selected the six features yielding higher quantities of pottery for which we have radiocarbon dates. The correlations revealed by the statistical analysis do not indicate chronological differences, even though the two clusters (A-B) of the first plot seems to partly suggest this, insofar as there are more black-painted and fewer tar-coated vessels in the later (Tisza II) period.

\subsection{Distribution of ornamentation types according to houses}

The analysis of the same dataset with a focus on the houses with a secure chronological position yielded similar results regarding general tendencies (Fig. 25). However, the location of the buildings offers an alternative explanation. The early buildings (red squares) fall into the negative range of the $\mathrm{x}$ axis, while the late ones (blue lozenges) are scattered. The statistics would indicate a change in the buildings' function or in the activities performed in them. While storage jars and strainers are more dominant in the early (Tisza I) buildings, we find a preponderance of decorated pottery and lids in the material from the late (Tisza II) buildings. Since the buildings can be ordered into stratigraphic pairs owing to the reconfiguration of the settlement layout, i.e. the late buildings were rebuilt over earlier ones, it was possible to compare the functions of the buildings according to these pairs in view of the 

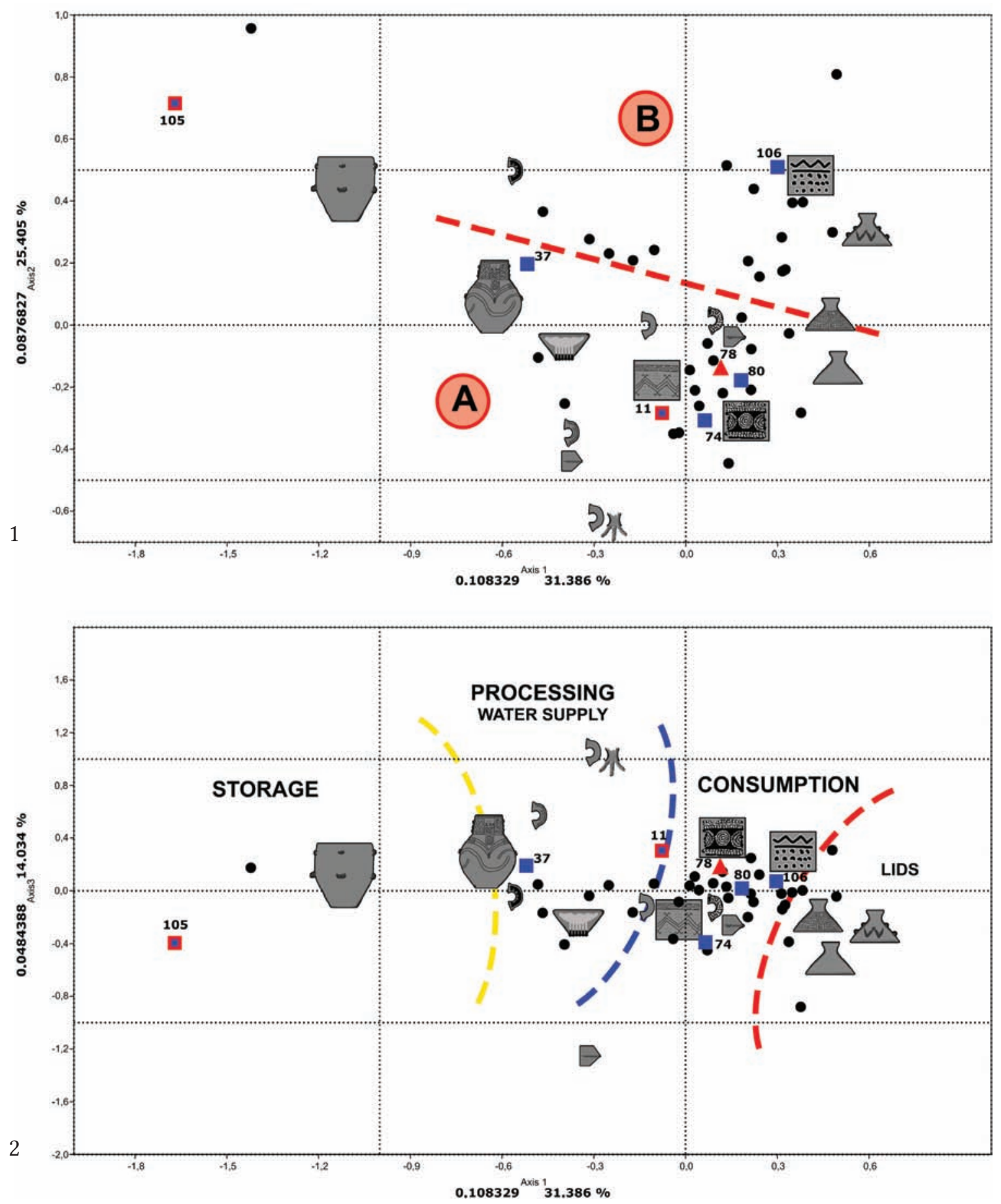

Fig. 24. The correspondence analysis of the pottery from Öcsöd-Kováshalom based on the data of the fragmented material from the pits containing over 200 pottery fragments, showing also the radiocarbon-dated pits (red triangle: early occupation, blue square: late occupation, red-blue square: transitional period). The variables are combinations of formal attributes (storage jars, strainers, lids, handles, biconical carination) and ornamental attributes (incised, painted, tar-coated, applied). 1 - Axes 1 and 2: the clusters of ornamental techniques show the separateness of the features with a higher proportion of painted pottery (A) from pottery with incised decoration and tar coating (B). Although the pattern would suggest a chronological separation, this was not confirmed by the radiocarbon dates. 2 - Axes 1 and 3: the clusters according to functional groups: the storage, processing, water supply and consumption series ends with the lids. The cluster of ornamented pottery shows a strong correlation between social display as expressed by style and fine wares and consumption. 
stable house locations. There was a strong link between two of these three pairs, while the material from Houses 2 and 5 shared the fewest similarities. It is perhaps not mere chance that the function of the buildings changed substantially exactly in the locations where the settlement layout was significantly transformed.

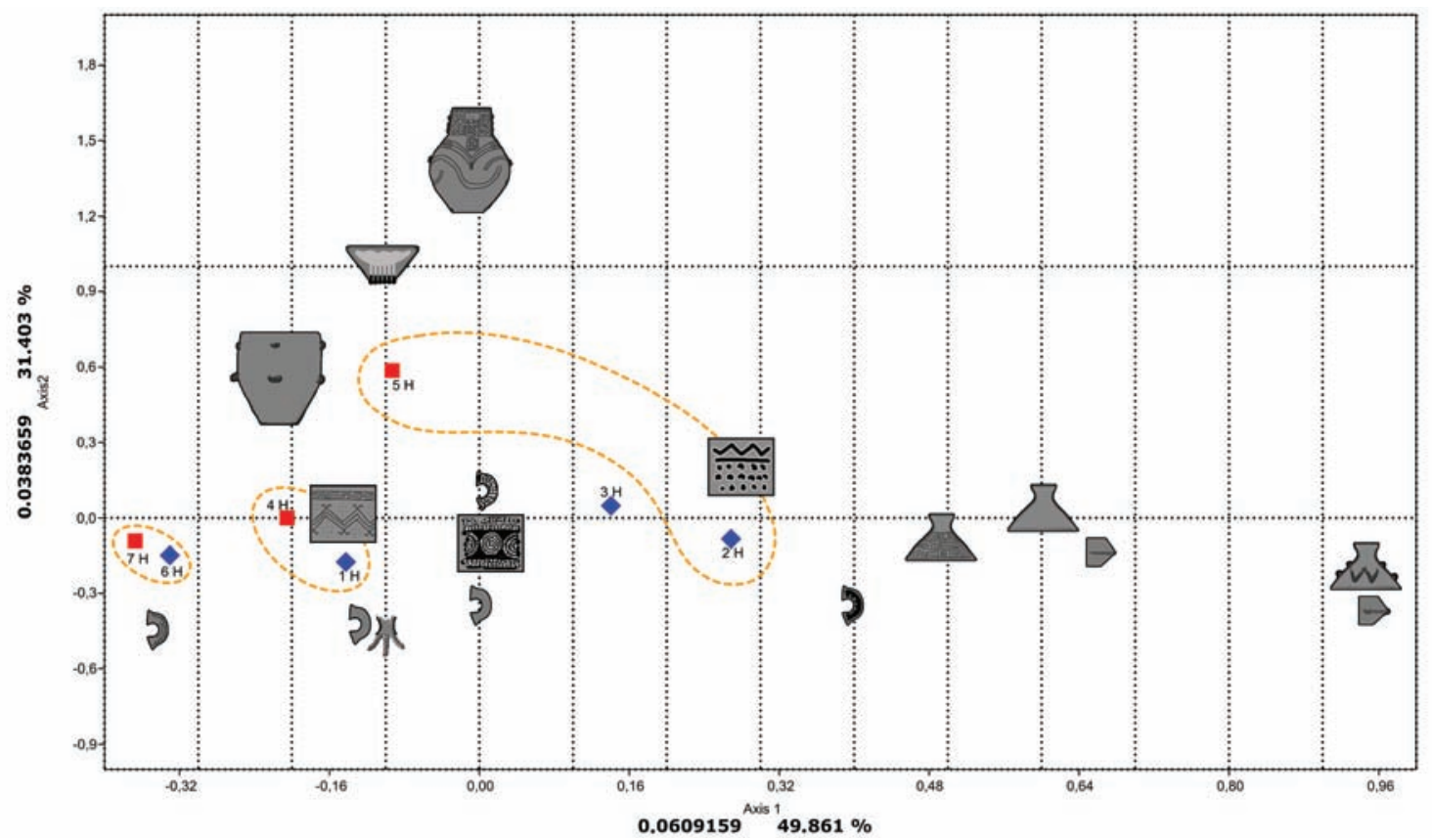

Fig. 25. The correspondence analysis of the pottery from Öcsöd-Kováshalom based on the data of the fragmented material from the houses (red square: early occupation, blue lozenge: late occupation). The variables are combinations of formal attributes (storage jars, strainers, lids, handles, biconical carination) and ornamental attributes (incised, painted, tar-coated, applied). The houses built on the same spot are linked with yellow dashed lines. The differences between the buildings of the early and the late occupation are shown by Houses 2 and 5 in the clusters based on vessel functions and the technique and extent of vessel ornamentation. The two buildings located in a central spot and yielding remarkable ceramic assemblages both in terms of quantity and quality confirm the changes in the function of the houses.

\subsection{The stylistic attributes of the ornamentation}

Following the style analysis of the refitted and reconstructed vessels, we assembled a catalogue of the decorative elements (Fig. 26), in which the decorative bands under the rim, the vertical divider bands, the closed decorative elements and the filler patterns are all included. We found a definite correlation between certain decorative elements and certain vessel parts and forms, confirming the contention that style is a blend of form, technique and ornamentation. ${ }^{134}$

We performed a seriation, comparing the vessel forms and the main decorative elements, for examining the transformation of ceramic style over time (Fig. 27). In order to determine chronological correlations, the vessels originating from the early and late buildings as well as from the pits of uncertain age appear separately. The overall picture is one of a continuously changing vessel set, in which the partial transformation of vessel forms is accompanied by a definite change in ornamentation. 

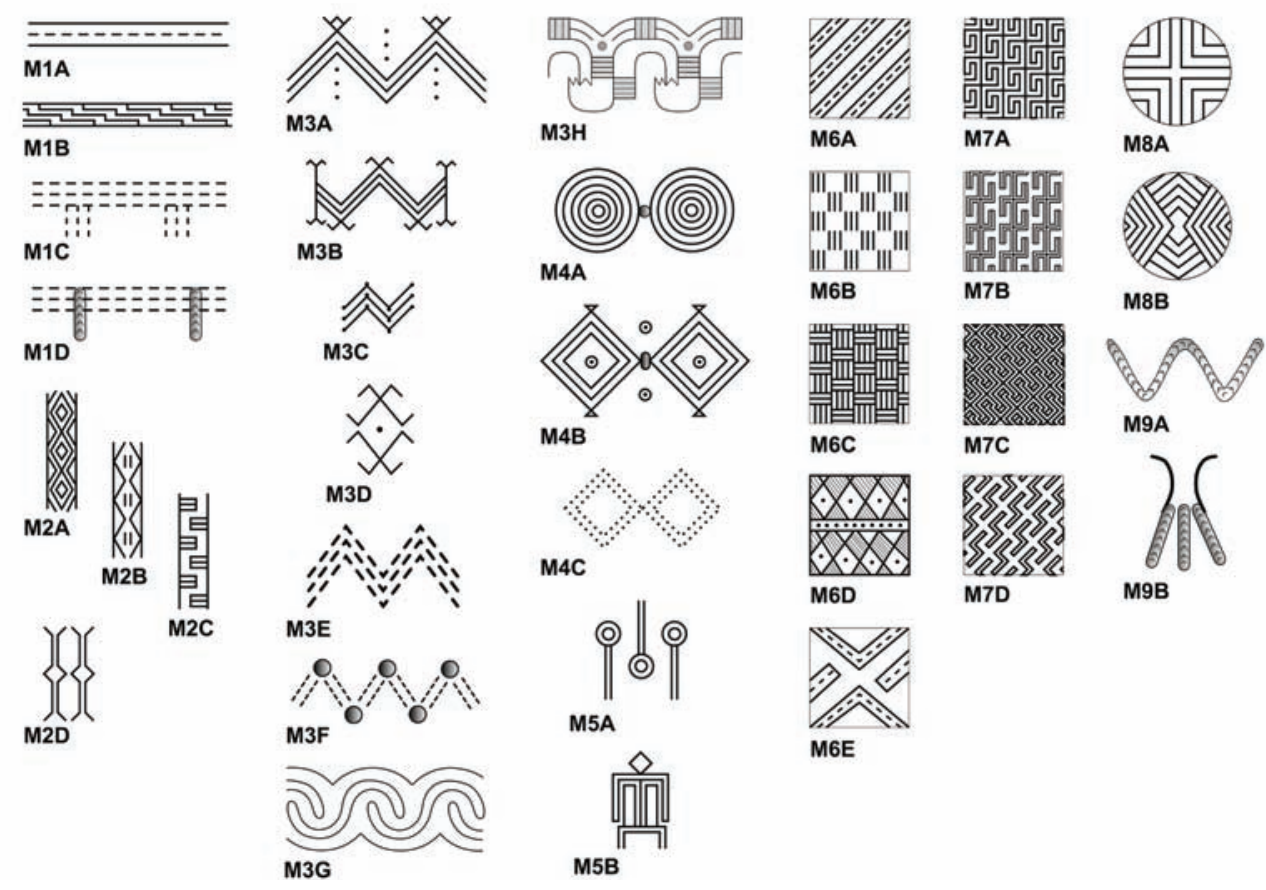

Fig. 26. Typology of the designs on the refitted vessels from Öcsöd-Kováshalom: M1 - horizontal bands, M2 - vertical divider bands, M3 - patterns encircling the vessel body and composite patterns, M4 - patterns of concentric elements, M5 - special motifs and anthropomorphic design elements, M6 simple filler patterns, M7 - textile patterns, M8 - circular filler patterns, M9 - applied design elements.

The material of the early horizon (Öcsöd A) represents the late Szakálhát and the formative Tisza (Tisza I) style characterised by various bowls (T1C, T2, T3B, T3C), cups (T4) and small-sized vessels (T5, T6). Obviously, the dominance of these vessels forms is relative because these types also occur in the late ceramic inventory, although the ornamented pieces can be mostly assigned to the early period. The bowls are adorned with interlocking recumbent S motifs, accentuated with red pastose painting, so typical of Szakálhát pottery (Fig. 45.2). Simple patterns along the rim and above the carination, applied to vessel surfaces of differing proportion, are the most typical. These include bands of short stabs, black-painted bands and simple (or occasionally impressed) knobs in various combinations (M1C-D).

It follows from the position of small-sized closed vessels (T4, T5, T6) in the vessel set that the distinctive style elements occur among these ceramics. These include zig-zag patterns encircling the vessels harking back to the classical ALPC style (M3A), while the complementary geometric motifs at the break-points of the bundles of lines (triangles, lozenges, tent-motifs) (Fig. 33.4) are typical of the late Szakálhát style. The variant of this pattern created from bands of short incisions combined with applied elements is likewise typical for Szakálhát pottery (M3F).

The segmented bundles of lines terminated at each end $(\mathrm{M} 3 \mathrm{~B}-\mathrm{C})$ appearing in design structures of two or four vertical fields represent the stylistic development of the terminal Middle Neolithic. The divider elements are straight lines or rows of lozenges (M2B). A so-called step motif (M1B) generally runs under the rim. Main designs made up of concentric circles or lozenges forming an ornamental design around the carination represent the typical style of the early horizon (M4A-B). The incised variant of this simple ornamentation can be found in itself 
or accentuated with red pastose painting, and the variant created with bands of short stabs also occurs (M4C). Circle- and lozenge-based patterns created from chopped straw embedded into a tar coating appear on cups (T4; Fig. 56.6).

Conical lids are one characteristic vessel type of the early period. The coarser pieces bear circumferential patterns of oblique bands of short stabs and the occasional filler designs (M3E), alongside simple incised zig-zag patterns and partial zig-zags of applied ribs (M9A). More ornate lids are covered with simple filler designs such as chequerboard patterns (M6C), with the decorative fields separated by simple bundles of lines (M1A-B).

The pottery of the late horizon (Öcsöd B) corresponds to the developed Tisza (Tisza II) period. Biconical vessels (T6) retain their prominence during this period too, while other typical types are conical and flowerpot-shaped vessels (T7) and flat lids (T12B). Geometric patterns arranged in rectangular fields dominate vessel decoration, to which the form of the above three vessel types was eminently suited. The fields are separated by bands filled with various motifs such as step motifs (M1B), concentric lozenges (M2A), special elements (M2C-D) and the occasional closed element (M3D), but incised human figures sometimes also separate the main ornamental fields. ${ }^{135}$ While chequerboard patterns continue to be used as simple filler designs (M6B), there is a clear shift towards various more sophisticated meandric patterns (M7A-C) and meander patters created from closed elements (M7D). The latter are generally labelled textile patterns and this mode of ornamentation was termed the textile style in Hungarian archaeological schol-

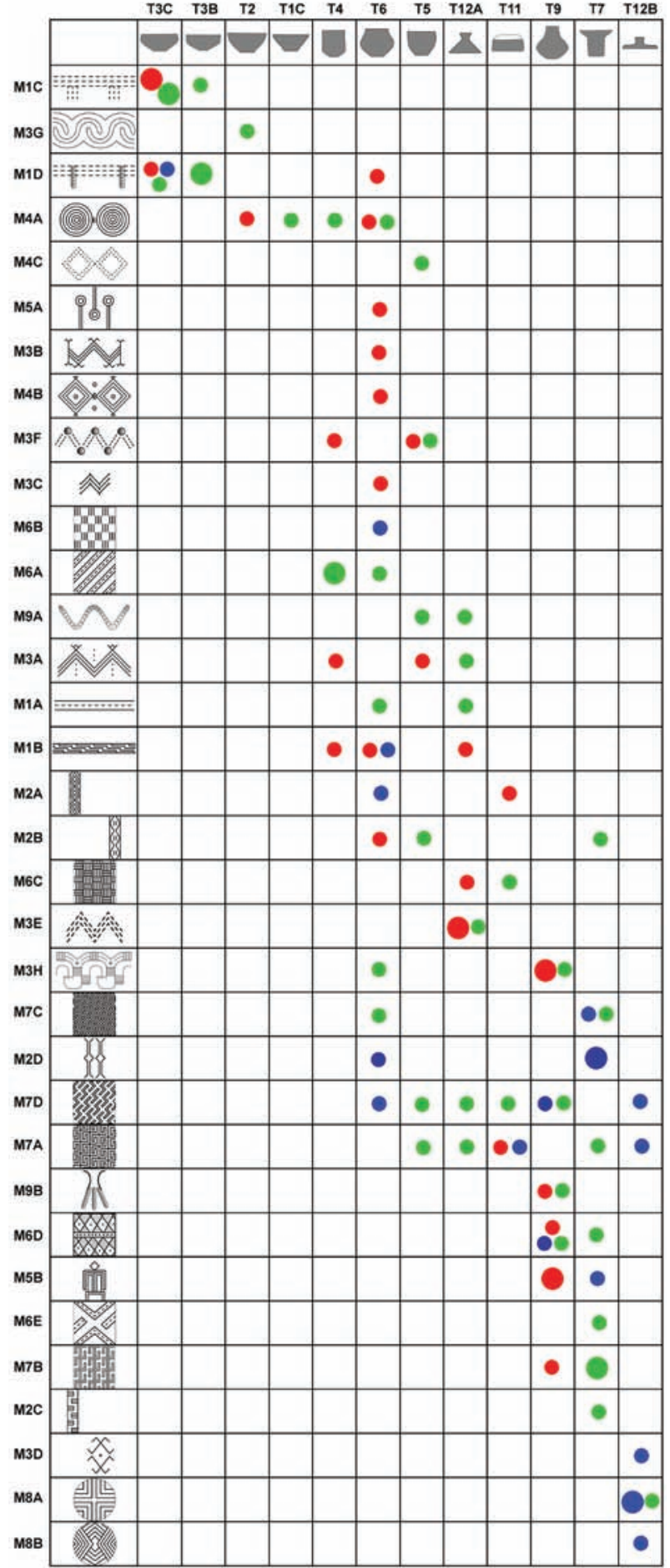

Fig. 27. Seriation of the vessels from ÖcsödKováshalom based on formal types and ornamentation. Vessels from the early houses are marked with red, vessels from the late houses with blue and vessels from pits of uncertain date with green. Small circles mark one vessel, large circles two vessels. 
arship. ${ }^{136}$ Flat disc-shaped lids are generally covered with cross- and herringbone-based simple filler patterns (M8A-B).

Although the lower horizon of the tell-like settlement is clearly dominated by late Szakálhát elements, patterns typical for the classical Szakálhát style can be found alongside rudimentary textile designs, heralding the ensuing developmental phase. The slow, gradual transformation of pottery styles has been archaeologically documented in several cases. ${ }^{137}$ The changes of the Szakálhát/Tisza transitional period have most recently been discussed by Katalin Sebők..$^{138}$ The broader acceptance of the polythetic cultural approach in archaeology has led to a better awareness of the fact that assemblages can be heterogeneous in nature. ${ }^{139} \mathrm{~A}$ better understanding of the transformation of ceramic styles was also promoted by the realisation that development can be asynchronous, namely that the transformation of material culture can proceed at different rhythms and be of a different nature on the micro-regional level or even on the level of individual sites, ${ }^{140}$ as has been demonstrated, for example, in the case of the assemblage from Tiszaug-Vasútállomás, a settlement in the broader area of Öcsöd-Kováshalom. ${ }^{141}$

The Öcsöd assemblage represents the period of the emergence of the archaeological unit conventionally labelled as "Tisza culture", which was defined on the basis of an ornamental style. The gradual transformation of the ceramic style confirms the local community's active agency in the renewal of the community's identity and its material expression. The nature of this transformation and the social relevance of the changes can best be demonstrated through the large face pots of the vessel deposit (Fig. 32.6), as presented and discussed in several previous studies. ${ }^{142}$ Dating from the period marking the transformation of the settlement's early occupation around $5000 \mathrm{BC}$, the vessel deposit represents a special context in the site's material. Of the two vessels in this deposit (Fig. 32.6-7), the remarkable bowl can only be linked to this context, while the fragments of the large face pot were in part found in the deposit and in part scattered over the settlement, ${ }^{143}$ the latter enabling the reconstruction and interpretation of the vessel's afterlife. The vessel's original function, the purposeful discarding of a part of the vessel fragments and the reconstruction of the series of events relating to the vessel deposit highlights the extraordinary significance of both the assemblage and of the face pot.

Let us now turn to the style analysis of the vessel's ornamentation. We focused on the complex design structure on the vessel's belly (Fig. 28.3). ${ }^{144}$ One distinctive trait of the design is that the large interlocking curved motifs are combined with filler motifs arranged in panels. The latter are simple grid-, zig-zag- and lozenge-based motifs. By uniting these two elements,

136 Csalog 1941, 5, 19; SEBőK 2009.

137 Goldman 1984; Kalicz 1989.

138 SЕВŐK 2017.

139 Clarke 1968, 35-37; Delanda 2006; Furholt 2011. The contention that the typical ceramic attributes of earlier and later periods as well as of neighbouring regions (groups) can occur together within an assemblage is not alien to archaeological thought. Although this was successfully applied in the identification of spatial-chronological units (cf. RACZKY 1983), it was later neglected in ceramic analyses and pottery assemblages were treated as "monothetic" units.

140 MeIER-ARENDT 1994.

141 FÜZESI et al. 2017.

142 RACZKY 2000; RACZKY - FÜZESI 2016b; RACZKY - FÜZESI 2018; RACZKY - FÜZESI - ANDERS in press.

143 RACZKY - FüZESI 2018, Fig. 3.

144 Previous analyses focused on the patterns on the cylindrical neck and the anthropomorphic traits: RACZKY 2000, 11; RACZKY - FÜZESI 2016b, 26. 
the design blends not only the two basic design structures of the Middle and Late Neolithic, but also the two fundamental styles of face pots. ${ }^{145}$ The early, amphora-shaped face pots ${ }^{146}$ are characterised by a design of interlocking S motifs encircling the vessel body, as on the vessel from Szentes-Ilonapart. ${ }^{147}$ The other type is represented by cylindrical face pots with a design structure made up of panels filled with meander patterns. ${ }^{148}$ The ornamental panels occupy a prominent position in the design structure of garlands and arcs, at the break-point and the centre of the arcs. In the case of garlands encircling the vessels (design elements 1 and 3), we may at the most speak of complementary elements (design elements 4 and 6), while the panels added to the middle zone resulted in a step-wise alternating pattern (5a-d). Individual elements had different meanings as shown by the two different terminations of the panels (5a$\mathrm{b}$ and $5 \mathrm{c}-\mathrm{d}$ ) and the dissimilar filler pattern (Fig. 28.1-3). The significance of the ornamental band is accentuated by the series of anthropomorphic depictions set on the same panel (5b).

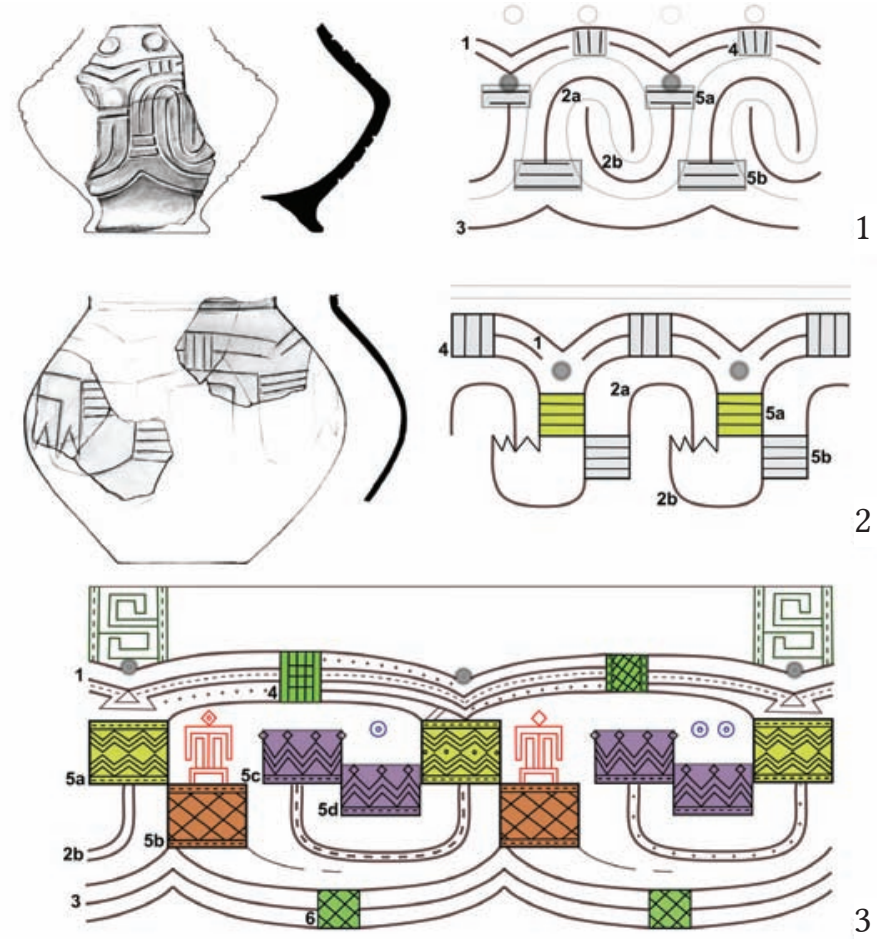

Fig. 28. The design on the remarkable face pot from Öcsöd-Kováshalom (3) and its versions on other vessels from the site (1-2). The design elements in an identical position are marked with the same numbers.

More recently, the idea of cultural hybridisation has become an accepted approach in archaeological studies, ${ }^{149}$ contributing much to a better understanding of development and transformation. The visible increase in the number of individual preferences in some periods is a reflection of the crumbling of a community's accepted norms and of the efforts to create a new visual discourse. The increase in the number of individual designs is indirectly an indication of the shift in the balance between individual and community identity. Obviously, this does not mean that the need for a community identity has been discarded, merely the demand

145 Sево̋к - KovÁcs 2009; SЕвőк 2017, 116-117, Fig. 6.

146 Designated as cooking pot-shaped face pots by Katalin Sebők (SEвőк - KovÁcs 2009, 83).

147 Kalicz - Makkay 1977, Tab. 189. 7.

148 SEBŐK - KovÁcs 2009.

149 Deagan 2013; Stockhammer 2012. 
for a new visual idiom differing from the traditional and conventional one. During innovative periods of this type ${ }^{150}$ we witness the appearance of several new elements or of the novel application of old ones that, although later discarded in the community's practice, nevertheless play an important role in precipitating social changes.

The blend of the two design structures typical for face pots is not unusual in the late Szakálhát material. The best counterparts to the Öcsöd design can be found on a vessel from Battonya-Gödrösök. Despite its heavy fragmentation, György Goldman succeeded in reconstructing the vessel's design. ${ }^{151}$ The position of the panels in the design structure only corresponds partly to the structure of the Öcsöd vessel. The middle zone with the anthropomorphic elements is less emphatic on the Battonya vessel, signalling a more simple version of the same design than at Öcsöd.

Simplified variants of the design of the face pot are also encountered in the material of the Öcsöd site (Fig. 28). A comparison of the designs indicates a significant structural similarity between them. We marked the corresponding design spaces on the roll-outs. The increasing simplification of the designs can be attributed to the size of the vessels and the decrease in the available space suitable for ornamentation. The vessel shown in Fig. 28.2, for example, has panels filled with simple parallel hatching, which provides a springboard for understanding the decoration of the third vessel in an almost minimalistic style (Fig. 28.1), which can also be regarded as the condensed form of the visual concept. The designs analysed here hark back to the popular recumbent $S$ motifs and the recumbent meanders of the Szakálhát style, which can be found in the material of the early horizon. The entire range of the design elements of the face pot illustrates the transformation of the Szakálhát style, which occurred in association with the general transformation of the Öcsöd settlement in other spheres too. The singular syntax of the large vessel's ornamentation expressed the new canon of the changes in the community through the new synthesis of the earlier ornamental elements. This novel imagery is an expression of the new Late Neolithic visual vocabulary in the heartland of the Great Hungarian Plain.

In the above, we mapped the main tendencies of local pottery production and pottery consumption at Öcsöd-Kováshalom as reflected by the assemblage of the refitted and reconstructed vessels. The gradual transformation of vessel forms, the changes in the composition of the local vessel set and the development of the ornamental style reflect social and economic processes whose imprints can be discerned in the site's ceramic inventory. The micro-level processes in the life of the local community can be fitted into the framework of the socio-economic development marking the onset of the Late Neolithic and the emergence of the Tisza cultural formation. ${ }^{152}$ A broader analysis of these processes would exceed the scope of this study and thus we shall only provide a broad outline of the regional frame of the formal range of the vessels from Öcsöd-Kováshalom.

150 The model of adaptive cycles suggests an increased likelihood of innovation during periods of transformation (Gronenborn et al. 2017, 54-55; Holling - Gunderson 2002; LeE Allock 2017, Fig. 1).

151 Goldman 1978, Tab. XI.

152 The complexity of the transition between the Middle and the Late Neolithic on the Great Hungarian Plain was first discussed in detail by János Makkay and Andrew Sherratt (MAKKaY 1982; SHERratT 1982-1983). This transition was studied on a micro-regional level by the international research teams led by Attila Gyucha and William Parkinson (Gyucha et al. 2015). 


\section{6. Öcsöd-Kováshalom and the broader context of the Late Neolithic Tisza cultural entity}

\subsection{The archaeological study of the material entities hallmarked by the Tisza ceramic style}

The label "Tisza culture" was first used by Ferenc Tompa in $1929,{ }^{153}$ at roughly the same time as Childe published his seminal monograph on the prehistory of the Danube region. ${ }^{154}$ Tompa regarded pottery decorated with incised and painted patterns, representing one of the find material's specific segments, as the culture's principal hallmark. ${ }^{155}$ The first decades of studies on this culture were taken up with clarifying the culture's chronological position and cultural contacts. ${ }^{156}$ Only after World War 2 was the chronological sequence of Neolithic development on the Hungarian Plain established, enabling a critical review of the place of the Tisza culture in this development. ${ }^{157}$

János Banner can be credited with undertaking the first adequately documented excavations investigating a larger area, for example at Hódmezővásárhely-Kökénydomb. ${ }^{158}$ Following his work, fieldwork on Late Neolithic sites began in the late 1950s, as a result of which the layer sequences of the tell settlements at Tápé-Lebő, ${ }^{159}$ Hódmezővásárhely-Gorzsa, ${ }^{160}$ Szegvár-Tűzköves, ${ }^{161}$ Öcsöd-Kováshalom, ${ }^{162}$ Vésztő-Mágor ${ }^{163}$ and Berettyóújfalu-Herpály ${ }^{164}$ as well as a section of the single-layer settlement at Kisköre-Gát ${ }^{165}$ became known. The assemblages recovered from these sites gave a new impetus to the period's study. These key sites and their finds were showcased as part of an international exhibition in $1987 .{ }^{166}$ The model of Late Neolithic development constructed at this time provided the necessary inspiration for a fresh look at, and critical review of, the entire period, leading to a spate of studies and comprehensive overviews of the Late Neolithic in its broader European context in the late 1980s and the 1990s. ${ }^{167}$

Research on the Late Neolithic of the northern Hungarian Plain was in part conducted parallel to the investigations in the southern Hungarian Plain. Early research in the northern region was restricted to the soundings opened on various sites, among others by Ida Bognár-Kutzián, Nándor Kalicz, Lajos Kiss, János Makkay, Pál Patay, József Petróczi and Ferenc Tompa ${ }^{168}$ Later, Polgár-Csőszhalom, a site lying in the foreland of the Zemplén Mountains, was chosen for

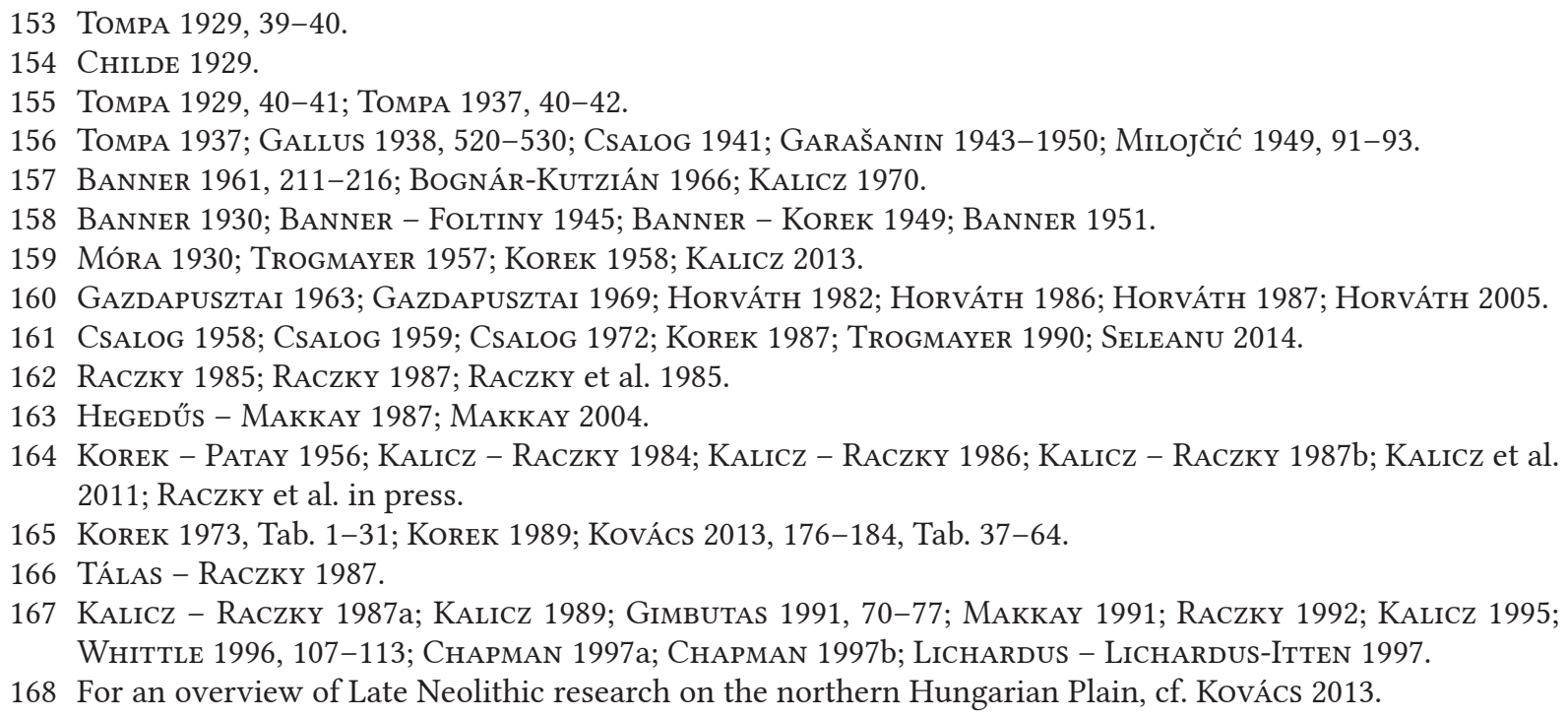


extensive investigations. ${ }^{169}$ The connections of this site with the Lengyel culture linked the settlement to the one investigated at Aszód. ${ }^{170}$

Archaeological scholarship in the post-war period focused on the chronological role of pottery, leading to the birth of several studies on ceramic style, among which the works of József Csalog must by all means be highlighted. ${ }^{171}$ In his analysis of the Bükk and Tisza ceramic styles, he demonstrated the differing nature of the cognitive patterns underlying the two ornamental modes. His identification of textile patterns and their association with spinning and weaving largely determined the course of later studies on ceramic style. ${ }^{172}$ The functional interpretation of pottery appeared in Hungarian archaeological scholarship in the 1980s. The large-scale topographic projects directed scholarly attention to settlement networks and the development of settlements, and to prehistoric economies in relation to them. János Makkay's comprehensive overview of Neolithic studies in Hungary was based on the topographic data from County Békés. He compared the settlement networks of the Middle and the Late Neolithic alongside estimates of the region's carrying capacity, and he also used the volume data of the pottery brought to light during various excavations. ${ }^{173}$

Replacing the earlier sweeping analyses, ${ }^{174}$ the turn of the millennium saw the advent of micro-regional research focusing on smaller areas. Melinda Hajdú surveyed the Late Neolithic sites in the Sajó and Hernád Valleys in north-eastern Hungary in her MA thesis, ${ }^{175}$ while Katalin Kovács analysed the Late Neolithic development in the northern Hungarian Plain, with a focus on the Bodrogköz region. ${ }^{176}$ Katalin Sebők undertook the detailed analysis of objects decorated in the textile style, demonstrating that while the ornamentation that served for identifying the culture was indeed one of the hallmarks of the culture's ceramic inventory, it could actually be found on a numerically smaller portion of the finds themselves. ${ }^{177}$ Research teams organised for addressing various issues opened a new chapter in the study of the Late Neolithic of Hungary. The assessment of the tell and the single-layer settlement of Polgár-Csőszhalom with a focus on the settlement's households was performed between 2012 and 2015. ${ }^{178}$ Simultaneously, several research projects addressing Late Neolithic settlement patterns and various issues of landscape archaeology on a micro-regional level were conducted in the Körös region by a team led by William Parkinson, Attila Gyucha, Paul Duffy and Roderick Salisbury. ${ }^{179}$ When designing research agendas, an approach proceeding from the micro scale ${ }^{180}$ towards broader regional contexts gained currency ${ }^{181}$ complemented by the inclusion of new sites ${ }^{182}$ and new source materials in the analyses. ${ }^{183}$

169 RACZKy et al. 1997; RACZKy et al. 2002; BÁNFFy - BognÁr-KutZiÁn 2007.

170 KalicZ 1985; Kalicz 2006; Kalicz 2008.

171 Csalog 1941; Csalog 1955.

172 Chapman - Richter 1999; Richter 2003; Richter 2005; SebőK 2009; RACZKy - FÜZeSi 2018.

173 MAKKAY 1982.

174 Cf. MAKKay 1982; SherRatT 1982-1983.

175 Hajdú 2014, 67-101.

176 KovÁcs 2013.

177 Distributed over an extensive area, the pattern remained unchanged for a long time. However, only 532 finds from nine sites could be included in the analysis (ХЕво̋к 2009, 6, 39).

178 RACZKY et al. 2015.

179 Parkinson 2002; Parkinson 2006; Duffy et al. 2013; Gyucha et al. 2015; SAlisbury 2016.

180 FÜZESI 2009; RACZKY - ANDERS 2009.

181 Sebők et al. 2013; FArAgó 2016; Kovács 2016; FArAgó 2017.

182 Polgár-Bosnyákdomb (RACzky - Anders 2016); Pusztataskony-Ledence (SEBőK - FArAgó 2018).

183 Chapman et al. 2010; Magyari et al. 2012; Moskal-Del-Hoyo 2013; Bittner 2016; Salisbury 2016. 
In the wake of the research conducted over the past century, several stratified and single-layer settlements located in various micro-regions of the Great Hungarian Plain are known in detail. The new research directions evolving after the turn of the millennium involved the detailed assessment of the find assemblages from these sites as well as their systematic review. The preparation of the reports on the Öcsöd-Kováshalom site from 2016 onward was part of this work.

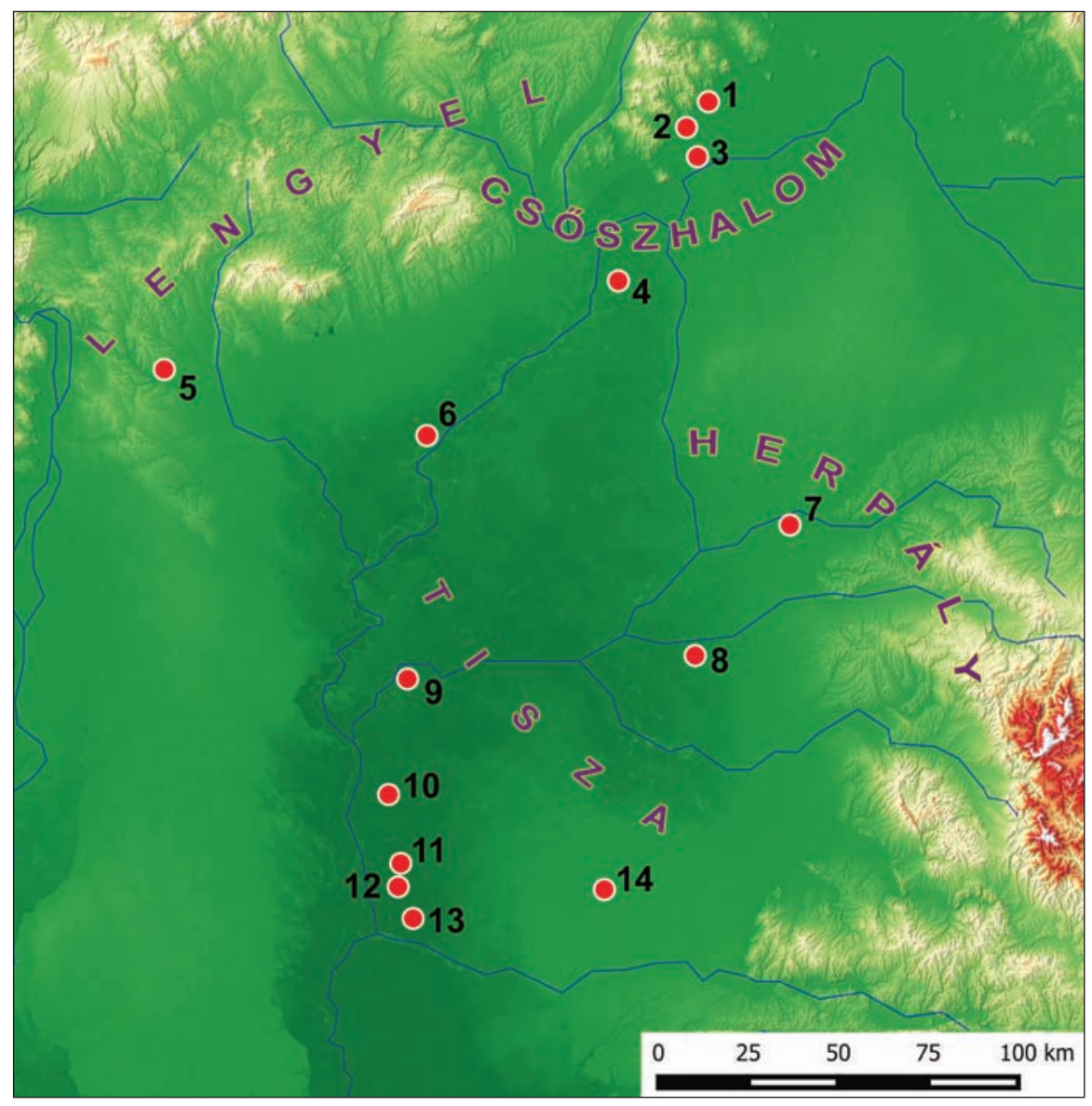

Fig. 29. The published Late Neolithic sites on the Great Hungarian Plain mentioned in the text. $1-$ Sárospatak-Vár, 2 - Bodrogzsadány (Sárazsadány)-Templomdomb, 3 - Kenézlő-Fazekaszug, 4 - Polgár-Csőszhalom, 5 - Aszód-Papi földek, 6 - Kisköre-Gát, 7 - Berettyóújfalu-Herpály, 8 - Vésztő-Mágor, 9 - Öcsöd-Kováshalom, 10 - Szegvár-Tűzköves, 11 - Hódmezővásárhely-Kökénydomb, 12 - Hódmezővásárhely-Gorzsa, 13 - Tápé-Lebő, 14 - Battonya-Gödrösök.

\subsection{Trends in Late Neolithic pottery}

Thirteen Late Neolithic sites are known from the Great Hungarian Plain whose published material enabled a comparison with the vessels from Öcsöd discussed in this study (Fig. 29) and the setting of our findings in a broader cultural context. Detailed typological tables are available for the vessel forms of the Tisza culture in general ${ }^{184}$ as well as for individual sites. ${ }^{185}$ The pottery assemblages brought to light in various regions of the Great Hungarian Plain date from different periods and together they span the entire Late Neolithic developmental sequ-

184 Korek 1973, Figs 28-30; Sebők 2009, Tabs 55-61.

185 Kisköre-Gát (Kovács 2013, Tab. 61-64), Polgár-Csőszhalom (SEвők 2007; SEвők et al. 2013), Sárospatak-Vár (Kovács 2013, Tab. 84-85), Szegvár-Tüzköves (SELEAnu 2014). 
ence. Several studies have already covered the transformation of the ceramic style, ${ }^{186}$ and thus we shall here focus on changes in the vessel forms of the ceramic inventory. The level of the assessment of the assemblages varies considerably and a detailed comparison would exceed the scope of this preliminary analysis. Instead, we shall present and discuss the four trends in the transformation of Late Neolithic ceramic inventories that we deem to be the most salient.

The chronological sequence constructed from the layer sequences of tell settlements distinguishes three main periods, each characterised by different ceramic forms and types. ${ }^{187}$ The finds of the earliest period (Tisza I) are attested in the central and southern Hungarian Plain. The pottery from the Battonya-Gödrösök site bore the distinctive traits of late Szakálhát, while the ceramic inventories from Hódmezővásárhely-Kökénydomb, Szegvár-Tüzköves and Vésztő-Mágor, the earliest tell settlements of the Late Neolithic, share countless similarities.

The most distinctive stylistic attribute of the Tisza culture is the so-called textile style and the so-called flowerpot-shaped vessel associated with it. These ceramic attributes are lacking in the Szakálhát/Tisza transitional period or occur but sparsely. In contrast, the most typical types of the formative Tisza period are the small biconical vessels (T6) with slightly articulated rim and low pedestal. The most characteristic vessel forms as well as their ornamentation of concentric circles and lozenges (M4A-B) attested at Öcsöd appear among the finds from Hódmezővásárhely-Kökénydomb and Szegvár-Tüzköves too. This vessel type is among the typical forms of the early horizon (Öcsöd A), whose formal variants occur in the late material too (Öcsöd B). The vessel type and the associated ornament of concentric circles are the distinctive ceramic attributes of the Szakálhát/Tisza transition, ${ }^{188}$ which can also be found on other ceramic types such as semispherical bowls and cups, the latter often also adorned with designs of chopped straw embedded into tar, a decorative technique typical of the early Tisza period.

Biconical vessels and the style they represent are supplanted by flowerpot-shaped vessels (conical vessels, T7) in the Tisza assemlages. This distinctive vessel form and the textile pattern strongly associated with it has been reported from most sites, excepting the northernmost ones (Bodrogzsadány-Templomdomb, Sárospatak-Vár). The vessel form itself underwent a series of smaller changes during the culture's development. While the early finds are made up of conical and cylindrical forms with straight rim (Battonya-Gödrösök, Hódmezővásárhely-Gorzsa, Öcsöd-Kováshalom, Szegvár-Tűzköves, Vésztő-Mágor), Phases II and III are characterised by variants with a slightly everted rim (Hódmezővásárhely-Kökénydomb, Kisköre-Gát, Vésztő-Mágor), a conically widening mouth (Aszód-Papi földek, Hódmezővásárhely-Gorzsa, Kenézlő-Fazekaszug, Szegvár-Tűzköves, Tápé-Lebő) and, finally, with a funnel-like rim (Aszód-Papi földek, Berettyóújfalu-Herpály, Kenézlő-Fazekaszug, KisköreGát, Polgár-Csőszhalom). The vessel's role in social display is accentuated by its ornamentation as well as by the fact that it was used for consumption, and thus it also sheds light on the role of feasting in the community's life. ${ }^{189}$

Another significant tendency is the transformation of pedestals, one of the typical formal elements. In addition to their size and form, the vessel types also changed. Given that the most frequent pedestalled vessel types such as bowls and cups can be associated with consumption,

186 RACZky 1992; Lichardus - Lichardus-ItTEN 1997; SEBőK 2017.

187 Cf. RACZKY 1992, 164-170, Figs 1-3, 5.

188 KaliCZ 1989.

189 Kalla et al. 2013. 
changes in these vessels possibly reflect the transformation of consumption patterns. ${ }^{190}$ The finds of the early period (Tisza I) are characterised by bowls and small-sized vessels set on low conical pedestals (Battonya-Gödrösök, Hódmezővásárhely-Kökénydomb, Szegvár-Túzköves, Tápé-Lebő). Simple bowls remained in use over a longer period of time (Berettyóújfalu-Herpály, Hódmezővásárhely-Gorzsa). The taller conical pedestals, some with curved sides, first appeared at Szegvár-Túzköves. The typical vessel types of the late period are the bowls with tall, slightly bell-shaped pedestal. The low-bellied variants with an S profile and scalloped rim of these bowls also make their appearance (Aszód-Papi földek, Berettyóújfalu-Herpály, Kenézlő-Fazekaszug, Polgár-Csőszhalom, Sárospatak-Vár). These vessels can principally be found in the northerly regions and the eastern fringes of the Great Hungarian Plain, indicating not only chronological, but possibly also regional differences, especially in view of the vessel forms of the preceding period. ${ }^{191}$ One distinctive trait of the late period is that in addition to bowls and small-sized closed vessels (tableware), pedestals also appear in association with larger pot-shaped vessels (Kenézlő-Fazekaszug, Polgár-Csőszhalom). At the contemporaneous Herpály tell settlement, the low, conical pedestalled variant of almost every closed vessel type could be found, irrespective of size. The role of low pedestals differed substantially from that of the tall ones. Raising the vessel above the other ones imbued this element with a function of display, which is also borne out by its frequent ornamentation. Low foot-rings only elevate the vessel to a minimal extent; moreover, these were never decorated, suggesting that their value as a medium of display was low. ${ }^{192}$ The practical function of these types, at least in the late period, is indicated by the pots with foot-rings found at Herpály, whose size, form and fabric indicate that they were used for processing.

In terms of vessel forms, one general tendency is the growing complexity of vessel profiles. In the case of the most simple forms, profiles become more curved. Among cups, for example, straight rims are the norm on early Tisza sites (Aszód-Papi földek, Battonya-Gödrösök, Hódmezővásárhely-Kökénydomb, Öcsöd-Kováshalom, Szegvár-Tüzköves), while the cups in the ceramic inventories from late sites and from the northern Hungarian Plain acquire everted rims and forms with a definite S profile appear among them (Berettyóújfalu-Herpály, Bodrogzsadány-Templomdomb, Hódmezővásárhely-Gorzsa, Kenézlő-Fazekaszug, Polgár-Csőszhalom, Sárospatak-Vár). The impact of the Lengyel cultural influence can be seen in the appearance of cups with articulated neck on the northern sites (Aszód-Papi földek, Kenézlö-Fazekaszug, Sárospatak-Vár). Bowls underwent the most spectacular transformation during this period: the conical, spherical and biconical bowls with simple contours (Battonya-Gödrösök, Hódmezővásárhely-Kökénydomb, Kisköre-Gát, Öcsöd-Kováshalom, Szegvár-Tűzköves, Tápé-Lebő) were supplanted by bowls with an S profile and funnel-like everted rim (Aszód-Papi földek, Bodrogzsadány-Templomdomb, Hódmezővásárhely-Gorzsa,

190 Data on the volume of the vessels provide additional information on this issue. At present, a dataset of this type is only available for the 84 vessels from House 11 of the Berettyóúffalu-Herpály site (RACZKY et al. in press, Fig. 16).

191 Pedestals are infrequent in the Szakálhát assemblages from the southern Hungarian Plain, where small, foot-ring-like variants are the norm (KALICZ - MAKKAY 1977, 88; SzÉNÁszKy 1988, 7; FÜZESI et al 2017, 16, Fig. 8). In contrast, conical pedestals, including the variety with a curved upper part, were popular in the Berettyó region and the Upper Tisza region, home to the Esztár and Tiszadob ceramic styles (KALICZ MAKKay 1977, 39, 53; KuruCZ 1989, 30-31; GoldmAN - SzÉnÁsZKy 1994, 226-227; FÜZESI 2016, 381, Fig. 10).

192 Their practical function remains unclear; the separation of the vessel base can perhaps be associated with heat release. 
Polgár-Csőszhalom, Sárospatak-Vár) whose diameters exceeded the dimensions of earlier types. Among pots and storage jars, types with curved sides (Aszód-Papi földek, Battonya-Gödrösök, Hódmezővásárhely-Kökénydomb, Öcsöd-Kováshalom, Szegvár-Tűzköves, Tápé-Lebő) were replaced by varieties with a prominent carination (Aszód-Papi földek, Hódmezővásárhely-Kökénydomb, Sárospatak-Vár), an S-shaped (Kenézlő-Fazekaszug, Polgár-Csőszhalom, Vésztő-Mágor) or articulated profile (Polgár-Csőszhalom, Vésztő-Mágor). This tendency can be attributed to the development of pottery production on the one hand and to new external impulses on the other. The inter-regional trends in the Neolithic development of South-East Europe changed several times during this period and the communities living on the Hungarian Plain also took part in these changes. ${ }^{193}$

The fourth major change is represented by the transformation of the anthropomorphic vessels in the ceramic inventory. ${ }^{194}$ The Ócsöd assemblage includes three refitted and reconstructed face pots. Formal counterparts of the large amphoras with cylindrical neck (T9B) continuing Middle Neolithic traditions can be widely found across the Great Hungarian Plain, while the best formal and ornamental analogies can be cited from Battonya-Gödrösök. Anthropomorphic vessels are represented by one vessel in the assemblage (Fig. 53), whose best parallels can be found in the early Tisza assemblages of the Hungarian Plain (Hódmezővásárhely-Kökénydomb, Szegvár-Tűzköves, Vésztő-Mágor). Modelled anthropomorphic depictions appear among the lid handles (Fig. 44.3; Fig. 61.8), while incised variants on lids and amphoras (Fig. 32.6). ${ }^{195}$ The anthropomorphic vessels supplanting face pots and the rich diversity in the expression of human traits reflect the transformation of human (personal) roles. The colourful diversity in the iconography of human depictions is an indication of the broad scale of the transformation. ${ }^{196}$

Ȯcsöd-Kováshalom represents a specific initial phase in the Late Neolithic development of the Great Hungarian Plain in the Tiszazug micro-region. Its position in the Tisza culture's formative phase determined the nature of the site, made up of a tell-like and a single-layer settlement, and its layout of a central settlement area surrounded by smaller settlement clusters within a large triple and segmented enclosure, as well as the community's social and economic milieu. The finds and features brought to light at the site preserve the imprints of complex, multi-scalar processes in the community's life. The main goal of the analysis of the assemblage of 240 refitted and reconstructed vessels was to examine and interpret the possible imprints of these multi-level changes.

\section{Acknowledgements}

We are very grateful to Magdalena Seleanu for the English translation. The Öcsöd-Kováshalom project is funded by the National Research, Development and Innovation Office (Grant NKFIH, K-115815).

193 Makkay 1982; Sherratt 1982-1983; Parkinson 2002, Parkinson 2006; Raczky 2015; Salisbury 2016.

194 Sевőк 2009, 207-211, Tab. 40-41; Sebők - KovÁcs 2009; RACZKy 2015; SEBőк 2017.

195 RAсZкy 1987, 79, Figs 17-18, 20, 32-35, 44; RACZKy - FüZESI 2018, 154-156, Figs 6-7, 11.

196 For the archaeological evidence on the transformation of and growing differentiation in Late Neolithic societies, cf. SikLósi 2013. 


\section{References}

Arnold, D. E. 1985: Ceramic theory and cultural process. New Studies in Archaeology. CambridgeNewYork-Port Chester-Melbourne-Sydney.

ARNold, D. E. 2010: Design structure and community organization in Quinua, Peru. In: WASHBURN, D. K. (ed.): Structure and Cognition in Art. Cambridge, 56-73.

Arnold, P. J. III. 1991: Domestic Ceramic Production and Spatial Organization: A Mexican Case Study in Ethnoarchaeology. Cambridge.

BÁnffy, E. - Bognár-Kutzián, I. 2007: The Late Neolithic Tell Settlement at Polgár-Csőszhalom, Hungary. The 1957 Excavation. British Archaeological Reports - International Series, Archaelingua Central European Series 4/1730. Oxford.

BANNeR, J. 1930: A kökénydombi neolithkori telep (Die neolithische Ansiedlung von Kökénydomb). Dolgozatok 6, 49-158.

BANNER, J. 1951: A harmadik ásatás a hódmezővásárhelyi Kökénydombon (The third excavation on the Kökénydomb at Hódmezővásárhely). Archaeologiai Értesítő 78, 27-36.

BAnNeR, J. 1960: The neolithic settlement on the Kremenyák Hill at Csóka (Čoka). The excavations of F. Móra in the years 1907 to 1913. Acta Archaeologica Academiae Scientiarum Hungaricae 12, 1-56.

BAnNer, J. 1961: Einige Probleme der ungarischen Neolithforschung. In: Soudskŕ, B. - Pleslová, É. (eds.): L'Europe à la fin de l'âge de la pierre. Actes du Symposium international consacré aux problèmes du Néolithique européen. Prague, 205-219.

BANNER, J. - Foltiny, I. 1945: Újabb ásatás a hódmezővásárhelyi Kökénydombon (Neuere Ausgrabung im Kökénydomb bei Hódmezővásárhely). Folia Archaeologica 5, 8-34.

BAnNer, J. - KoReK, J. 1949: Negyedik és ötödik ásatás a hódmezővásárhelyi Kökénydombon (Les campagnes IV et V des fouilles pratiquées au Kökénydomb de Hódmezővásárhely). Archaeologiai Értesítő 76, 9-25.

BARABÁsi, A-L. 2016: Network Science. Cambridge.

BitTNER, B. 2016: A bedőlt falak néma falak? A lenyomatos paticsok vizsgálatának lehetőségei a késő neolitikumban az Alföldön (The fallen walls are silent walls? The possibilities of imprinted daub research in the Late Neolithic Hungarian Plains). Tisicum - A fász-Nagykun-Szolnok megyei múzeumok évkönyve 25, 33-40.

BognÁr-KutziÁn, I. 1966: Das Neolithikum in Ungarn. Archaeologia Austriaca. Beiträge zur Paleanthropologie, Ur- und Frühgeschichte Österreichs 40, 249-280.

Bowser, B. J. - Patton, J. Q. 2004: Domestic Spaces as Public Places: An Ethnoarchaeological Case Study of Houses, Gender and Politics in the Ecuadorian Amazon. Fournal of Archaeological Method and Theory 11, 157-181.

Chapman, J. 1997a: The origins of tells in Eastern Hungary. In: Topping, P. (ed.): Neolithic landscapes. Oxbow Monographs 86. Oxford, 139-187.

Chapman, J. 1997b: Places and Timemarks - the Social Construction of Prehistoric Landscapes in Eastern Hungary. In: NAsH, G. (ed.): Semiotics and Landscape: Archaeology of Mind. British Archaeological Reports - International Series 661. Oxford, 31-45.

Chapman, J. 2015: The Balkan Neolithic and Chalcolithic. In: Fowler, Ch. - Harding, J. - Hofmann, D. (eds.): The Oxford Handbook of Neolithic Europe. Oxford, 157-174.

Chapman, J. - Richter, É. 1999: Geometric order and scientific principles: a view from the mesolithic, neolithic and chalcolithic of Central and South East Europe. In: BodI, G. (ed.): In medias res praehistoriae. Miscellanea in honorem annos LXV peragentis Professoris Dan Monah oblata. Iaşi, 21-58.

Chapman, J. - Gillings, M. - Shiel, R. - Magyari, E. - Gaydarska, B. - Bond, C. 2010: The Upper Tisza Project. Studies in Hungarian landscape archaeology. Book 2: Settlement patterns in the Bodrogköz Block. British Archaeological Reports - International Series 2087, Oxford. 
Childe, G. V. 1929: The Danube in Prehistory. Oxford.

Clarke, D. 1968: Analytical Archaeology. London.

CsAlog, J. 1941: A magyarországi újabb-kőkori agyagművesség bükki és tiszai csoportja. Folia Archaeologica 3-4, 1-27.

CsALOG, J. 1955: A tiszai műveltség viszonya a szomszédos újkőkori műveltségekhez (Die Beziehungen der Theiss-Kultur zu den neolithischen Nachbarkulturen). Folia Archaeologica 7, 23-44.

Csalog, J. 1958: Das Wohnhaus „E” von Szegvár-Tüzköves und seine Funde. Acta Archaeologica Academiae Scientiarum Hungaricae 9, 95-114.

CsAlog, J. 1959: Die anthropomorphen Gefässe und Idolplastiken von Szegvár-Tüzköves. Acta Archaeologica Academiae Scientiarum Hungaricae 11, 7-38.

Csalog, J. 1972: Thronendes Frauenidol von Szegvár-Tüzköves. In: BAchermayer, F. (ed.): Idole. Prähistorische Keramiken aus Ungarn. Veröff. aus dem Naturhist. Museum. Neue Folge 7. Wien, 20-23.

CsÁNyi, M. 1981: A tiszazugi régészeti kutatások. In: SzABó, L. (ed.): 10 éves a Tiszazug kutatása (kutatási beszámoló). Szolnok, 10-16.

CsÁnyi, M - TÁRnOKI, J. 2011: Településrégészeti kutatások a Tiszazugban. In: BARTHA, J. - BenEDeK, Cs. - Gecse, A. (eds.): Életjel. Tanulmányok az ezredvégi Tiszazug népéletéből. Szolnok, 7-36.

Csornay, B. - Oravecz, H. - Vicze, M. 1985: The pottery of the 1983 campaign. In: Raczky, P. - SEleanu, M. - Rózsa, G. - Siklódi, Cs. - Kalla, G. - Csornay, B. - Oravecz, M. - Vicze, M. BÁNfFy, E. - BöкÖNYI, S. - Somogyi, P.: Öcsöd-Kováshalom. The intensive topographical and archaeological investigation of a Late Neolithic site. Preliminary report. Mitteilungen des Archäologischen Instituts der Ungarischen Akademie der Wissenschaften 14, 264-265.

DAvid, N. 1972: On the life span of pottery, type frequencies, and chronological inference. American Antiquity 37, 141-142.

Deagan, K. 2013: Hybridity, Identity and Archaeological Practice. In: CARD, J. J. (ed.): The Archaeology of Hybrid Material Culture. Center for Archaeological Investigations, Occasional Paper 39. Carbondale, 260-276.

DeBoer, W. - Lathrap, D. 1979: The making and breaking of Shipibo-Conibo ceramics. In: Kramer, C. (ed.): Ethnoarchaeology: implications of ethnography for archaeology. New York, 102-138.

Delage, Ch. 2017a: Once upon a time... the (hi)story of the concept of the chaine opératoire in French prehistory. World Archaeology 49, 158-173.

Delage, CH. 2017b: To what end a paper on the history of the concept of the chaîne opératoire? A response to Auduze et al. World Archaeology 49, 724-727.

DeLanda, M. 2006: A New Philosophy of Society: Assemblage Theory And Social Complexity. New York.

Doneus, M. 2001: Die Keramik der mittelneolithischen Kreisgrabenanlagen von Kamegg, Niederösterreich. Ein Beitrag zur Chronologie der Stufe MOG I der Lengyel-Kultur. Mitteilungen der Prähistorischen Kommission 46. Wien.

Duffy, P. R. - Parkinson, W. A. - Gyucha, A. - Yerkes, R. W. 2013: Coming Together, Falling Apart: A Multiscalar Approach to Prehistoric Aggregation and Interaction on the Great Hungarian Plain. In: Birch, J. (ed.): From Prehistoric Villages to Cities. Settlement Aggregation and Community Transformation. New York-Abington, 44-60.

FARAGÓ, N. 2016: Houses, Households, Activity Zones in the Post-LBK World. Results of the Raw Material Analysis of the Chipped Stone Tools at Polgár-Csőszhalom, Northeast Hungary. Open Archaeology 2, 346-367.

FARAGó, N. 2017: Differences in the selection of raw materials at the site of Polgár-Csőszhalom, northeast Hungary. Bulgarian e-fournal of Archaeology 7, 85-115.

FARAGÓ, N. 2019: Polgár-Csőszhalom késő neolitikus kő leleteinek komplex, háztartás alapú elemzése. $\mathrm{PhD}$ thesis, Eötvös Loránd University, Budapest. Manuscript. 
Furholt, M. 2008: Pottery, cultures, people? The European Baden material re-examined. Antiquity 82, 617-628.

Furholt, M. 2011: Zeichensysteme nach der Sesschaftwerdung. Keramik als Symbolträger und Vermittler sozialen Wandels im ägäischen Früh- und Mittelneolithikum. Eurasia Antiqua 17, 21-44.

FÜZESI, A. 2009: A neolitikus településszerkezet mikroregionális vizsgálata a Tisza mentén Polgár és Tiszacsege között (Mikroregionale Untersuchung des neolithischen Siedlungssystems entlang der Theiß zwischen Polgár und Tiszacsege). Tisicum - A Jász-Nagykun-Szolnok megyei Múzeumok Évköyve 19, 377-398.

FüzesI, A. 2016: The settling of the Alföld Linear Pottery Culture in Szabolcs-Szatmár-Bereg county. Microregional researches in the area of Mezőség in Nyírség. Dissertationes Archaeologicae 3/4, 369-393.

FÜZESI, A. IN PRESS: A késő neolitikus edények megformálásának technikai jellegzetességei Öcsöd-Kováshalom leletegyüttese alapján. In: $M \Omega M O \Sigma$ X. Öskoros Kutatók X. Összejövetelének konferenciakötete. Százhalombatta, In press.

Füzesi, A. - Faragó, N. - Raczky, P. 2017: Tiszaug-Railway-station. An archaic Middle Neolithic community on the Great Hungarian Plain. Dissertationes Archaeologicae 3/5, 7-66.

Gallus, S. 1938: Des mouvements vers les Balkans à la fin du néolithique. Revue International des Études Balkaniques 3, 520-530.

GaRAŠAnin, M. 1943-1950: Die Theiß-Kultur im jugoslawischen Banat. Bericht der Römisch-Germanischen Kommission 33, 125-132.

GazdapusztaI, Gy. 1963: Későneolitikus telep és temető Hódmezővásárhely-Gorzsán (Siedlung und Friedhof an den Spätneolithikum in Hódmezővásárhely-Gorzsa). A Móra Ferenc Múzeum Évkönyve 21-48.

GazdapusztaI, Gy. 1969: Probleme in der Südalföld-Gruppe der spätneolithischen Buckelkeramik. Študijné Zvesti AÚSAV 17, 125-139.

GeErTZ, C. 1973: The Interpretation of Cultures. New York.

GEERTZ, C. 2001: Az értelmezés hatalma. Budapest.

Gimbutas, M. 1991: The Civilization of the Goddess: The World of Old Europe. San Francisco.

Goldman, Gy. 1978: Gesichtsgefäße und andere Menschendarstellungen aus Battonya. Békés megyei Múzeumok Közleményei 5, 13-60.

Goldman, Gy. 1984: Battonya-Gödrösök, eine neolithische Siedlung in Südost-Ungarn. Békéscsaba.

Goldman, Gy. - SzÉNÁszky, J. 1994: Die neolithische Esztár-Gruppe in Ostungarn (A kelet-magyarországi Esztár csoport). A fósa András Múzeum Évkönyve 36, 225-230.

Gomart, L. 2014a: Traditions techniques \& production céramique au Néolithique Ancien. Étude de huit sites rubanés du nord est de la France et de Belgique. Leiden.

Gomart, L. 2014b: Quels facteurs d'emergence du premier Néolithique d'Europe tempérée? Apports de l'approche anthropologique d'assemblages céramiques du Néolithique ancien et moyen de Hongrie. What factors of emergence of the first Neolithic in temperate Europe? Contribution of the anthropological approach of ceramic assemblages from the early and middle Neolithic in Hungary. Annales de la Fondation Fyssen, 29, 143-160.

Gosselain, O. P. 1992: Technology and Style: Potters and Pottery among Bafia of Cameroon. Man New Series 27, 559-586.

Graves, M. W. 1991: Pottery production and distribution among the Kalinga: A study of household and regional organization and differentiation. In: LONGACRE, W. A. (ed.): Ceramic ethnoarchaeology. Tucson, 112-143.

Gronenborn, D. - Strien, H.-Ch. - Lemmen, C. 2017: Population Dynamics, Social Resilience Strate- 
gies, and Adaptive Cycles in Early Farming Societies of SW Central Europe. Quaternary International 446, 54-65.

Gyucha, A. - Yerkes, R. W. - Parkinson, W. A. - Apostolos, S. - Papadopoulos, N. - Duffy, P. R. SAlisbury, R. B. 2015: Settlement Nucleation in the Neolithic: A Preliminary Report of the Körös Regional Archaeological Project's Investigations at Szeghalom-Kovácshalom and Vésztő-Mágor. In: Hansen, S. - Raczky, P. - Anders, A. - Reingruber, A. (eds.): Neolithic and Copper Age between the Carpathians and the Aegean Sea. Chronologies and Technologies from the 6th and the 4th Millennium BCE. Bonn 129-142.

HAjDú, L. M. 2014: Újabb késő neolitikus lelőhelyek Borsod-Abaúj-Zemplén megyében. Newly discovered Late Neolithic archaeological sites sin Borsod-Abaúj-Zemplén County, Hungary. A Herman Ottó Múzeum Évkönyve 53, 67-101.

Hajdú, Zs. - NAgy, E. Gy. 2015: Különleges funkciójú, középső újkőkori tál Hajdúböszörmény határából. A Middle Neolithic bowl with a unique function from Hajdúböszörmény. Ősrégészeti Levelek - Prehistoric Newsletter 14, 25-31.

Hegedűs, K. - Makkay, J. 1987: Vésztő-Mágor. A settlement of the Tisza culture. In: TÁlas, L. Raczky, P. (eds.): The Late Neolithic of the Tisza Region. A survey of recent excavations and their findings: Hódmezővásárhely-Gorzsa, Szegvár-Túzköves, Öcsöd-Kováshalom, Vésztö-Mágor, Berettyóújfalu-Herpály. Budapest-Szolnok, 92-103.

HodDer, I. 1981: Pottery, production and use; a theoretical discussion. In: HowARd, H. - MorRIs, E. L. 1981. (eds.): Production and Distribution: a Ceramic Viewpoint. British Archaeological Reports International Series 120. Oxford, 215-220.

Hodder, I. 2012: Entangled: An Archaeology of the Relationships Between Humans and Things. Chichester.

Hofmann, R. 2013: Okolište 2 - Spätneolithische Keramik und Siedlungsentwicklung in Zentralbosnien. Neolithikum und Chalkolithikum in Zentralbosnien 2. Universitätsforschungen zur prähistorischen Archäologie 243. Bonn.

Hofmann, K. P. - Schreiber, S. 2011: Mit Lanzetten durch den practical turn. Zum Wechselspiel zwischen Mensch und Ding aus archäologischer Perspektive. Ethnographisch-Archäologische Zeitschrift 52, 163-187.

Holling, C. S. - Gunderson, L. H. 2002: Resilience and adaptive cycles. In: Gunderson, L. H. Holling, C. S. (eds.): Panarchy: understanding transformations in human and natural systems. Washington D.C., 25-62.

Horváth, F. 1982: A gorzsai halom későneolit rétege (The Late Neolithic Stratum of the Gorzsa tell). Archaeologiai Értesitó 109, 201-222.

Horváth, F. 1986: Aspects of Late Neolithic Changes in the Tisza-Maros Region. A Béri Balog Ádám Múzeum Évkönyve 13, 89-102.

Honváth, F. 1987: Hódmezővásárhely-Gorzsa. A settlement of the Tisza culture. In: TÁlas, L. RAczky, P. (eds.): The Late Neolithic of the Tisza Region. A survey of recent excavations and their findings: Hódmezövásárhely-Gorzsa, Szegvár-Tüzköves, Öcsöd-Kováshalom, Vésztö-Mágor, Berettyóújfalu-Herpály. Budapest-Szolnok, 31-46.

HoRvÁth, F. 2005: Gorzsa. Előzetes eredmények az újkőkori tell 1987 és 1996 közötti feltárásából. Gorzsa. Preliminary results of the excavation of the Neolithic tell between 1987-1996. In: BENDE, L. LőRInczy, G. (eds.): Hétköznapok Vénuszai. Hódmezővásárhely, 51-84.

HowARD, H. 1981: In the wake of distribution: towards an integrated approach to ceramic studies in prehistoric Britain. In: HowArd, H. - Morris, E. L. (eds.): Production and Distribution: a Ceramic Viewpoint. British Archaeological Reports - International Series 120. Oxford. 1-30.

Hunt, A. M. W. 2017 (ed.): The Oxford Handbook of Archaeological Ceramic Analysis. Oxford.

Kaczanowska, M. - Koz£owski, J. K. - SüMegi, P. 2009: Lithic industries from the Öcsöd-Kováshalom tell-like settlement in Hungary. In: Draşovean, F. - Ciobotaru, D. L. - Maddison, M. (eds.): Ten Years After: The Neolithic of the Balkans, as Uncovered by the Last Decade of Re- 
search. Proceedings of the Conference held at the Museum of Banat on November 9th-10th, 2007. Timişoara, 125-149.

Kalicz, N. 1957: Tiszazug őskori települései. Régészeti Füzetek 8. Budapest.

Kalicz, N. 1970: Über die Beziehung der Theiß- und Lengyel-Kultur. Acta Archaeologica Academiae Scientiarum Hungaricae 22, 13-23.

Kalicz, N. 1985: Kőkori falu Aszódon. Neolithisches Dorf in Aszód. Múzeumi Füzetek 32, Aszód.

Kalicz, N. 1989: Chronologische und terminologische Probleme im Spätneolithikum des Theißgebietes. In: BöкÖNYI, S. (ed.): Neolithic of Southeastern Europa and its Near Eastern Connections. Varia Archaeologica Hungarica 2. Budapest, 103-122.

KALICZ, N. 1995: Siedlungsstruktur der neolithischen Herpály-Kultur in Ostungarn. In: Aspes, A. (ed.): Settlement Patterns between the Alps and the Black Sea $5^{\text {th }}$ to $2^{\text {nd }}$ Millenium B.C. Verona - Lazise 1992. Memorie del Museo Civico di Storia Naturale di Verona (II ${ }^{a}$ serie) Sezione Scienze dell'Uomo 4. Verona, 67-75.

Kalicz, N. 2006: Die Bedeutung der schwarzen Gefäßbemalung der Lengyel-Kultur aus Aszód (Kom. Pest, Ungarn). Analele Banatului 14, 135-157.

Kalicz, N. 2008: Aszód: ein gemischter Fundort der Lengyel- und Theiss-Kultur. Communicationes Archaeologicae Hungariae 5-54.

KaLicz, N. 2013: Siedlungsstruktur und Bestattungen im Prestigeobjekten des Funplatzes Tápé-Lebő (südliches Theißgebiet, Ungarn). In: Anders, A. - Kulcsár, G. - Kalla, G. - Kiss, V. V. Szabó, G. (eds.): Moments in Time. Papers Presented to Pál Raczky on His 60th Birthday. Ősrégészeti Tanulmányok - Prehistoric Studies 1. Budapest, 365-384.

Kalicz, N. - Makкay, J. 1977: Die Linienbandkeramik in der Grossen Ungarischen Tiefebene. Studia Archaeologica 7, Budapest.

Kalicz, N. - Raczky, P. 1984: Preliminary Report on the 1977-1982 Excavations at the Neolithic and Bronze Age Settlement of Berettyóújfalu-Herpály. Part I: Neolithic. Acta Archaeologica Academiae Scientiarum Hungaricae 36, 85-136.

KALicz, N. - RAczKy, P. 1986: Ásatások Berettyóújfalu-Herpály neolitikus és bronzkori tell-településén 1977-1982 között. Újkőkor. Bihari Múzeum Évkönyve 4-5, 63-127.

Kalicz, N. - Raczky, P. 1987a: The Late Neolithic of the Tisza Region. A survey of recent archaeological research. In: TÁlas, L. - Raczky, P. (eds.): The Late Neolithic of the Tisza Region. A survey of recent excavations and their findings: Hódmezövásárhely-Gorzsa, Szegvár-Tüzköves, Öcsöd-Kováshalom, Vésztő-Mágor, Berettyóújfalu-Herpály. Budapest-Szolnok, 11-30.

Kalicz,N. - RACZKy,P.1987b: Berettyóújfalu-Herpály. A settlement of the Herpály culture. In:TÁLAs, L. Raczky, P. (eds.): The Late Neolithic of the Tisza Region. A survey of recent excavations and their findings: Hódmezővásárhely-Gorzsa, Szegvár-Túzköves, Öcsöd-Kováshalom, Vésztő-Mágor, Berettyóúffalu-Herpály. Budapest-Szolnok, 105-125.

Kalicz, N. - Raczky, P. - Anders, A. - Kovács, K. 2011: Preserved by Ancestral Fires. Pictures of an excavation. The Neolithic village at Berettyóúffalu-Herpály. Budapest.

Kalla, G. - Raczky, P. - V. Szabó, G. 2013: Ünnep és lakoma a régészetben és az írásos forrásokban. $\mathrm{Az}$ őskori Európa és Mezopotámia példái alapján. In: DérI, B. (ed.): Convivium. Budapest, $11-46$.

KnAppett, C. (ed.) 2013: Network Analysis in Archaeology. New Approaches to Regional Interaction. Oxford.

Knopf, T. 2009: Keramik in der Archäologie: Möglichkeiten und Grenzen der Interpretation (Pottery in Archaeology: Possibilities and Limits of Interpretation). In: StоскнаммеR, P. (ed.): Keramik jenseits von Chronologie. Beiträge der Arbeitsgemeinschaft 'Theorie in der Archäologie' bei der Tagung des West- und Süddeutschen Verbandes für Altertumsforschung e.V. in Xanten, 7.-8. Juni 2006. Internationale Archäologie Arbeitsgemainschaft. Symposium. Tagung. Kongress Band 14. Rahden/Westf., 1-10. 
KoHring, S. 2013: Conceptual knowledge as technologically materialised: a case study of pottery production, consumption and community practice. In: Stig Sørensen, M. L. - Rebay-SAlisbury, K. (eds.): Embodied Knowledge. Perspectives on Belief and Technology. Oxford-Oakville, 106-116.

KoneK, J. 1958: Lebő-halmi ásatás 1950-ben (The excavation at Lebő-halom in 1950). Archaeologiai Értesitő 85, 132-155.

Korek, J. 1973: A tiszai kultúra. PhD dissertation. HAS, Budapest. Manuscript.

KoRek, J. 1987: Szegvár-Túzköves. In: TÁlas, L. - Raczky, P. (eds.): The Late Neolithic of the Tisza Region. A survey of recent excavations and their findings: Hódmezövásárhely-Gorzsa, Szegvár-Tüzköves, Öcsöd-Kováshalom, Vésztó-Mágor, Berettyóújfalu-Herpály. Budapest-Szolnok, 47-60.

Korek, J. 1989: Die Theiß-Kultur in der mittleren und nördlichen Theißgegend. Inventaria Praehistorica Hungariae 3, Budapest.

Konek, J. - Patay, P. 1956: A Herpályi-halom kőkorvégi és rézkori települése (The settlement at Herpályhalom from the late Neolithic and the Copper Age). Folia Archaeologica 8, 23-42.

KovÁcs, Gy. - CsÁnyi, M. - TÁRnoki, J. 2017: Topográfiai kutatások a Tiszazugban (Jász-NagykunSzolnok megye) (Topograhic research in the Tiszazug area [Jász-Nagykun-Szolnok County]). In: Benkő, E. - Bondár, M. - Kolláth, Á. (eds.): Magyarország Régészeti Topográfiája. Múlt, jelen, jövő. Archaeological Topography of Hungary. Past, Present and Future. Budapest, 239-253.

Kovács, K. 2013: A tiszai kultúra településtörténetének, belső kronológiájának és kapcsolatrendszereinek vizsgálata Északkelet-Magyarországon (The settlement pattern, chronology and cultural relations of the Tisza Culture in Northeast Hungary). PhD thesis, Eötvös Loránd University, Budapest. Manuscript. http://doktori.btk.elte.hu/hist/kovacskatalin/diss.pdf

KovÁcs, K. 2016: Településszerkezeti sajátosságok Kenderes-Kulis kora rézkori lelőhelyén: az elmúlt évtizedek kutatási eredményei (The Characteristics of Settlement Structure at the Early Copper Age Site Kenderes-Kulis. The Results of Research Conducted in the Past Decades). Tisicum - A Jász-Nagykun-Szolnok megyei Múzeumok Évkönyve 25, 55-63.

KovÁcs, Zs. E. - GÁL, E. 2009: Animal remains from the site of Öcsöd-Kováshalom. In: DraşoveAn, F. Ciobotaru, D. L. - Maddison, M. (eds.): Ten Years After: The Neolithic of the Balkans, as Uncovered by the Last Decade of Research. Proceedings of the Conference held at the Museum of Banat on November 9th-10th, 2007. Timişoara, 151-157.

Kreiter, A. - Marton, T. - Gomart, L. - Oross, K. - PánczéL, P. 2017: Looking into houses: analysis of LBK ceramic technological change on a household level. In: BuRnEz-LANOTTE, L. (ed.): Metières à Penser: Raw materials acquisition and processing in Early Neolithic pottery productions. Proceedings of the Workshop of Namur (Belgium), 29 and 30 May 2015. Paris, 111-132.

Kurucz, K. 1989: A nyíri Mezőség neolitikuma. A nyíregyházi Jósa András Múzeum kiadványai 28. Nyíregyháza.

KvĚtina, P. - KončElová, M. 2011: Sherds on the Map. Intra-site GIS of the Neolithic Site of Bylany (Czech Republic). In: Verhagen, D. - Posluschny, A. G. - Danielisova, A. (eds.): Go Your Own Least Cost Path. Spatial technology and archaeological interpretation. Proceedings of the GIS session at EAA 2009, Riva del Garda. British Archaelogical Reports - International Series 2284. Oxford, 55-65.

LeE Allock, S. 2017: Long-term socio-environmental dynamics and adaptive cycles in Cappadocia, Turkey during the Holocene. Quaternary International 446, 66-82.

Lichardus, J. - Lichardus-Itten, M. 1997: Spätneolithische Funde von Čičarovce (Ostslowakei) und das obere Theißgebiet an der Schwelle zur frühen Kupferzeit. Saarbrücker Studien und Materialien zur Altertumskunde 4-5 (1995-96), 143-249.

LucAs, G. 2017: Variations on a Theme: Assemblage Archaeology. Cambridge Archaeological fournal 27, 187-190.

Magyari, E. - Chapman, J. - Fairbairn, A. S. - Francis M. - DE Guzman, M. 2012: Neolithic human impact on the landscapes of North-East Hungary inferred from pollen and settlement records. 
Vegetation History and Archaeobotany 21, 279-302.

Mаккау, J. 1963: Különös régészeti leletek a Jósa András Múzeumban. A fósa András Múzeum Évkönyve 3, 7-26.

MaKkay, J. 1982: A magyarországi neolitikum kutatásának új eredményei. Az időrend és a népi azonositás kérdései. Budapest.

Makкay, J. 1991. Entstehung, Blüte und Ende der Theiß-Kultur. In: Lichardus, J. (ed.): Die Kupferzeit als historische Epoche. Bonn, 319-328.

MaккAY, J. 2004: Vésztő-Mágor. Ásatás a szülőföldön. Békéscsaba.

MARTON, T. 2015: A dunántúli vonaldíszes kerámia kultúrájának kerámialeletei Balatonszárszóról. $\mathrm{PhD}$ thesis, Eötvös Loránd University, Budapest. Manuscript.

Meier-Arendt, W. 1994: Bemerkungen zum Begriff der „Stilwanderung” in der prähistorischen Archäologie am Beispiel des Mittelneolithikums Zentraleuropas. In: LőRINCZY, G. - BENDE, L. (eds.): A kőkortól a középkorig. Tanulmányok Trogmayer Ottó 60. születésnapjára. Szeged, 85-93.

Milojčić, V. 1949: Chronologie der jüngeren Steinzeit Mittel- und Südosteuropas. Berlin.

MórA, F. 1930: Ismeretlen tipusu edény Lebőről (Ein Gefäss unbekannten Typs von Lebő). Szegedi Dolgozatok 6, 159-162.

MoskAL-DEL-Hoyo, M. 2013: Mid-Holocene forests from Eastern Hungary: new anthrocological data. Review of Palaeobotany and Palynology 193, 70-81.

NickLIN, K. 1981: Pottery production and distribution in southeast Nigeria. In: HowARD, H. Morris, E. L. (eds.): Production and Distribution: a Ceramic Viewpoint. British Archaeological Reports - International Series 120. Oxford, 169-186.

Orton, C. - Tyers, P. - Vince, A. 1993: Pottery in Archaeology. Cambridge.

Parkinson, W. A. 2002: Integration, Interaction, and Tribal 'Cycling': The Transition to the Copper Age on the Great Hungarian Plain. In: PArkinson, W. A. (ed.): The Archaeology of Tribal Societies. International Monographs in Prehistory - Archaeological Series 15. Ann Arbor, 391-437.

PARkinson, A. W. 2006: Tribal boundaries: Stylistic variability and social boundary maintenance during the transition to the Copper Age on the Great Hungarian Plain. American Antiquity, 33-58.

PAvLŮ, I. 2000: Life on a Neolithic Site. Bylany - Situational Analysis of Artefacts. Praha.

PAvúk, P. 2010: Pottery Processing at Troy. Typology, Stratigraphy and Correspondence Analysis: How do they Work Together? In: Horejs, B. - Jung, R. - PAvúk, P. (eds.): Analysing Pottery. Processing Classification - Publication. Studia Archaeologica et Medievalia X. Bratislava, 73-98.

PeAcock, D. P. S. 1981: Archaeology, ethnology and ceramic production. In: HowARD, H. - MorRIs, E. L. (eds.): Production and Distribution: a Ceramic Viewpoint. British Archaeological Reports - International Series 120. Oxford,187-194.

Pechtr, J. 2015: Linearbandkeramik Pottery and Society. In: Fowler, Ch. - Harding, J. - Hofmann, D. (eds.): The Oxford Handbook of Neolithic Europe. Oxford, 555-572.

Pétrequin, A. M. - Pétrequin, P. - Weller, O. 2006: Objets de pouvoir en Nouvelle-Guinée. Etude ethnoarchéologique d'un système de signes sociaux 1-2. Paris.

PfäLzner, P. 2013: Activity-area Analysis: A Comprehensive Theoretical Model. In: MüLler, M. (ed.): Household Studies in Complex Societies. (Micro)Archaeological and Textual Aprroaches. Papers from the Oriental Institute Seminar. Chicago, 29-60.

RACzky, P. 1983: A kora neolitikumból a középső neolitikumba való átmenet kérdései a Közép- és Felső-Tisza-vidéken (Questions of transition between the early and middle Neolithic in the Middle and Upper Tisza region). Archaeologiai Értesitő 110, 161-194.

Raczky, P. 1987: Öcsöd-Kováshalom. A settlement of the Tisza culture. In: TÁlas, L. - Raczky, P. (eds.): The Late Neolithic of the Tisza Region. A survey of recent excavations and their findings: 
Hódmezővásárhely-Gorzsa, Szegvár-Túzköves, Öcsöd-Kováshalom, Vésztő-Mágor, BerettyóúffaluHerpály. Budapest-Szolnok, 61-83.

Raczky, P. 1992: The Tisza Culture of the Great Hungarian Plain. Studia Praehistorica 11-12, 162-176.

Raczky, P. 2000: A unique face pot from the Öcsöd-Kováshalom settlement of the Tisza culture. Acta Archaeologica Academiae Scientiarum Hungaicae 51, 9-22.

Raczky, P. 2009: Archaeological Data on Space Use at Tell-Like Settlement of the Tisza Culture (New results from Öcsöd-Kováshalom). In: Draşovean, F. - Ciobotaru, D. L. - Maddison, M. (eds.): Ten Years After: The Neolithic of the Balkans, as Uncovered by the Last Decade of Research. Proceedings of the Conference held at the Museum of Banat on November 9th-10th, 2007. Timişoara, $101-124$.

Raczky, P. 2015: Settlements in South-East Europe. In: Fowler, Ch. - Harding, J. - Hofmann, D. (eds.): The Oxford Handbook of Neolithic Europe. Oxford, 235-253.

Raczky, P. - Anders, A. 2003: The internal relations of the Alföld Linear Pottery culture in Hungary and the characteristics of human representation. In: JEREM, E. - RAcZKY, P. (eds.): Morgenrot der Kulturen. Frühe Etappen der Menschheitgeschichte in Mittel- und Südosteuropa. Festschrift für Nándor Kalicz zum 75. Geburtstag. Budapest, 155-182.

Raczky, P. - Anders, A. 2009: Settlement History of the Middle Neolithic in the Polgár Micro-region (The Development of the Alföld Linearband Pottery in the Upper Tisza Region, Hungary). In: KozŁowski, J. K. (ed.): Interactions between different models of Neolithization north of the Central European Agro-Ecological Barrier. Prace Komisji Prehistorii Karpat PAU 5. Kraków, 31-50.

Raczky, P. - Anders, A. 2016: Polgár-Bosnyákdomb, a Late Neolithic Tell-like Settlement on Polgár Island (NE Hungary). Preliminary Results of the Investigations. Folia Quaternaria 84, 99-122.

Raczky, P. - Anders, A. - Nagy, E. - Kurucz, K. - Hajdú, Zs. - Meier-Arendt, W. 1997: Polgár-Csőszhalom-dűlő. Újkőkor végi telep és sírok a Kr. e. V. évezredből (Late Neolithic settlement and graves fromthe 5th Millennium B.C.). In: RAczky, P. - KovÁcs, T. - ANDERs, A. (eds.): Utak a múltba - Az M3-asautópálya régészeti leletmentései. - Paths into the Past Rescue excavations on the M3 motorway. Budapest, 34-43, 168-174.

Raczky, P. - Anders, A. - Sebők, K. - Csippán, P. - Tóth, Zs. 2015: The Times of Polgár-Csőszhalom. Chronologies of Human Activities in a Late Neolithic Settlement in Northeastern Hungary. In: Hansen, S. - Raczky, P. - Anders, A. - Reingruber, A. (eds.): Neolithic and Copper Age between the Carpathians and the Aegean Sea. Chronologies and technologies from the 6th to the 4th millennium BCE. Archäologie in Eurasien Band 31. Bonn, 21-48.

RAcZKy, P. - FÜZESI, A. 2016a: Öcsöd-Kováshalom. A retrospective look at the interpretations of a Late Neolithic site. Dissertationes Archaeologicae 3/4, 9-42.

RACZKy, P. - FÜZESI, A. 2016b: A múlt szimbolikus eseményeinek rekonstrukciója - Régészeti esettanulmány Öcsöd-Kováshalom késő neolitikus településéről (The reconstruction of symbolic events from the past - The archaeological study of a Late Neolithic site at Òcsöd- Kováshalom). Tisicum - A fász-Nagykun-Szolnok megyei Múzeumok Évkönyve 25, 27-34.

RACZky, P. - FÜZESI, A. 2018: Unusual Clay Artefacts and their Imagery from the Late Neolithic Settlement of Öcsöd-Kováshalom on the Great Hungarian Plain. In: Țurcanu, S. - URsu, C.-E. (eds.): Materiality and Identity in Pre- and Protohistoric Europe. Homage to Cornelia-Magda Lazarovici. Suceava, $145-170$.

Raczky, P. - Meier-Arendt, W. - Anders, A. - Hajdú, Zs. - Nagy, E. - Kurucz, K. - Domboróczki, L. Sebők, K. - SÜmegi, P. - Magyari, E. - SzÁntó, Zs. - GulyÁs, S. - Dobó, K. - BÁcskay, E. Bíró, K. T. - Schwartz, Ch. 2002: Polgár-Csőszhalom (1989-2000). In: Aslan, R. - Blum, St. Kastl, G. - Schwitzer, Fr. - Thumm, D. (eds.): Mauerschau. Festschrift für Manfred Korfman. Remshalden-Grunbach, 833-860.

RAczкy, P. - S. Kovács, J. 2009: Festékanyag- és szerves edénybevonat-elemzések alföldi későneolitikus díszkerámiákon (Az első vizsgálati eredmények) (Analysis of pigments and organic coatings on 
the Late Neolithic fine wares of the Great Hungarian Plain [Preliminary results]). In: BENDE, L. LőRINCzy, G. (eds.): Medinától Etéig. Régészeti Tanulmányok Csalog fózsef Születésének 100. Évfordulójára. Szentes, 101-120.

RAсzкy, P. - SевŐK, K. 2014: The outset of Polgár-Csőszhalom tell and the archeological context of a special central building. In: ForţıU, S. - CînTAR, A. (eds.): Arheovest II.1. In honorem Gheorghe Lazarovici - Interdisciplinaritate in Arheologie. Timişoara 6 decembrie 2014. Szeged, 51-100.

Raczky, P. - Seleanu, M. - Rózsa, G. - Siklódi, Cs. - Kalla, G. - Csornay, B. - Oravecz, H. - Vicze, M. BÁnffy, E. - BöкÖNyi, S. - Somogyi, P. 1985: Öcsöd-Kováshalom. The intensive topographical and archaeological investigation of a Late Neolithic site. Preliminary report. Mitteilungen des Archäologischen Instituts der Ungarischen Akademie der Wissenschaften 14, 251-278.

Raczky, P. - FÜZESI, A. - Anders, A. In PREss: Domestic and Symbolic Activities on a Tell-like Settlement at Öcsöd-Kováshalom in the Tisza Region. Acta Terrae Septemcastrensis. In press.

Raczky, P. - FÜZEsi, A. - SebőK, K. - Faragó, N. - Csippán, P. - Anders, A. In press: A special house from the Late Neolithic tell settlement of Berettyóújfalu-Herpály (Hungary). Reconstruction of a two-storey building, its furnishings and objects from the earlier 5th millennium BC. In: BLUM, S. W. E. - Efe, T. - Kienlin, T. L. - Pernicka, E. (eds.) Manfred Korfmann commemorative volume. Tübingen. In press.

Rice, P. M. 1987: Pottery Analysis. A Sourcebook. Chicago-London.

Richter, É. 2003: A tiszai kultúra szőttes-jellegủ díszítésvilágának kapcsolata a szövés- és gyékényfonás motívumaival (The connection between the ornamental repertoire of the Tisza culture with the motifs of spinning and weaving). Ösrégészeti Levelek-Prehistoric Newsletter 5 , 98-106.

Richter, É. 2005: Textil- és négyzetrendszeres fonatlenyomatok az Alföld neolitikumából. In: BENDE, L. - LőRInczy, G. (eds.): Hétköznapok Vénuszai. Hódmezővásárhely, 123-144.

Ř́́dKÝ, J. - KončElová, M. - ŠumberovÁ, R. - Limburský, P. - KvĚtina, P. 2014: How Were Neolithic Ditches Filled In? Deposition Study of Two Encolsures from Bohemia. European fournal of Archaeology 17, 579-601.

Riebe, D. J. - Niziolek, L. C. 2015: Investigating Compositional Variation of Ceramic Materials during the Late Neolithic on the Great Hungarian Plain - Preliminary LA-ICP-MS Results. Open Geosciences 7, 423-445.

Roux, V. 2017: Ceramic Manufacture: The chaîne opératoire Approach. In: Hunt, A. M. W. (ed.): The Oxford Handbook of Archaeological Ceramic Analysis. Oxford, 101-113.

Salisbury, R. B. 2016: Soilscapes in Archaeology: Settlement and Social Organization in the Neolithic of the Great Hungarian Plain. Budapest.

Santacreu, D. A. - Trias, M. C. - Rosselló, J. G. 2017: Formal Analysis and Typological Classification in the Study of Ancient Pottery. In: Hunt, A. M. W. (ed.): The Oxford Handbook of Archaeological Ceramic Analysis. Oxford. 181-199.

Schier, W. 2000: Measuring Change: The Neolithic Pottery Sequence of Vinča-Belo Brdo. Documenta Praehistorica 27, 187-197.

Sево̋к, K. 2007: Ceramic forms of Polgár-Csőszhalom - a case study. In: KozŁowski, J. K. - RAczky, P. (eds.): The Lengyel, Polgár and Related Cultures in the Middle/Late Neolithic in Central Europe. Kraków, 97-116.

Sево̋к, K. 2009: A tiszai kultúra geometrikus díszítésú agyagtárgyai. PhD thesis, Eötvös Loránd University, Budapest. Manuscript.

SEвőK, K. 2016: Vessels with diverse lifes: examples of (decorated) pottery with a change of function. Poster presentation for the session TH6-03 Blurred borders? Making pottery and cultural interaction on Neolithic and Eneolithic Europe. 22nd Annual Meeting of the EAA. 31st August - 4th September 2016 Vilnius. https://www.academia.edu/29436024/2016_Sebok_K._Vessels_with_di- 
verse_lives_examples_of_decorated_pottery_with_a_change_of_function

SEво̋к, K. 2017: Evolution of a design system in the eastern part of the Carpathian Basin. Transformations of the vessel-based human representations of the Middle Neolithic Szakálhát culture and the genesis of the Late Neolithic Tisza culture's 'textile' decoration. Quaternary International, 2017 March.

SEвőк, K. 2018: On the possibilities of interpreting Neolithic pottery - Az újkőkori kerámia értelmezési lehetőségeiről. Dissertationes Archaeologicae 3/6, 13-42.

SebőK, K. - FARAGó, N. 2018: Theory into practice: basic connections and stylistic affiliations of the Late Neolithic settlement at Pusztataskony-Ledence 1. Dissertationes Archaeologicae 3/6, 147-178.

SEвőK, K. - KovÁcs, K. 2009: Hengeres testủ arcos edény töredékei a fiatal szakálháti-kultúra Rákóczifalva határában feltárt településéről (A cylindrical face pot from the Late Szakálhát settlement at Rákóczifalva). In: Bende, L. - Lőrinczy, G. (eds.): Medinától Etéig. Tisztelgő írások Csalog fózsef születésének 100. évfordulóján. Szentes, 81-91.

Sebők, K. - Faragó, N. - Hajdú, Zs. - Anders, A. - Raczky, P. 2013: Egy különleges kút és leletei Polgár-Csőszhalom késő neolitikus településéről. Archaeologiai Értesitő 138, 29-79.

SeleAnu, M. 2014: A Szegvár-túzkövesi neolitikus telepen 1978-ban végzett ásatás leletei és tanulságai. Budapest.

SeLLET, F. 1993: Chaine operatoire; the concept and its applications. Lithic Technology 18, 106-112.

Shepard, A. O. 1956/1995: Ceramics for the Archaeologist. Washington D.C.

SHERratT, A. 1982-1983: The development of neolithic and copper age settlement in the Great Hungarian Plain. Part I: The Regional Setting. Oxford Journal of Archaeology 1, 287-316; Part II: Site Survey and settlement dynamics. Oxford Fournal of Archaeology 2, 13-41.

SikLósi, Zs. 2013: Traces of Social Inequality during the Late Neolithic in the Eastern Carpathian Basin. Dissertationes Pannonicae 4/3. Budapest.

Sinopoli, C. M. 1991: Approaches to Archaeological Ceramics. New York.

StocкнаммеR, P. W. 2012: Conceptualizing Cultural Hybridization in Archaeology. In: SтоскнамMER, P. (ed.): Conceptualizing Cultural Hybridization. Transcultural Research - Heidelberg Studies on Asia and Europe in a Global Context. Berlin-Heidelberg, 43-58.

Strobel, M. 1997: Ein Beitrag zur Gliederung der östlichen Linienbandkeramik. Versuch einer Merkmalanalyse. SASTUMA 4-5 (1995-1996), 9-98.

SzÉNÁszky, G. J. 1988: A korai szakálháti kultúra Battyonyán (Funde aus der frühen Szakálhát-Kultur von Battonya). A Békés Megyei Múzeumok Közleményei 11, 5-29.

TÁlas, L. - Raczky, P. (eds.) 1987: The Late Neolithic of the Tisza Region. A survey of recent excavations and their findings: Hódmezővásárhely-Gorzsa, Szegvár-Tüzköves, Öcsöd-Kováshalom, Vésztö-Mágor, Berettyóúffalu-Herpály. Budapest-Szolnok.

TомpA, F. 1929: A szalagdíszes agyagmúvesség kultúrája Magyarországon. Die Bandkeramik in Ungarn. Archaeologia Hungarica 5. Budapest.

Tompa, F. 1937: 25 Jahre Urgeschichtsforschung in Ungarn 1912-1936. Bericht der Römisch-Germanischen Kommission, 24-25 (1934-35), 27-127.

Trogmayer, O. 1957: Ásatás Tápé-Lebőn (Ausgrabung auf Tápé-Lebő). A Móra Ferenc Múzeum Évkönyve, 19-60.

Trogmayer, O. 1990: Der Gott mit Axt. In: Meier-Arendt, W. (ed.): Alltag un Religion. Jungsteinzeit in Ost-Ungarn. Frakfurt am Main, 66-69.

VAnicsek, K. - Szakmány, Gy. - Horváth, F. - Kreiter, A. - Bendő, Zs. 2013: Előzetes eredmények Hórmezővásárhely-gorzsai tell késő neolit kerámiáinak (Tisza-kultúra Gorzsa-csoport) vizsgálatáról (Preliminary results of Late Neolithic ceramic analysis from Hódmezővásárhely-Gorzsa [Tisza Culture, SE Hungary]). Archeometriai Mühely 10, 5-12.

Whittle, A. 1996: Europe in the Neolithic. The creation of new worlds. Cambridge. 
Whittle, A. 2009: Problems in Neolithic archaeology. New Studies in Archaeology. Cambridge-New York.

Whittle, A. - Bayliss, A. - Barclay, A. - Gaydarska, B. - Bánffy, E. - Borić, D. - Draşovean, F. Jakucs, J. - Marić, M. - Orton, D. - Pantović, I. - Schier, W. - Tasić, N. - Vander Linden, M. 2016: A Vinča potscape: formal chronological models for the use and development of Vinča ceramics in south-east Europe. Documenta Praehistorica 43, 1-60.

Wiessner, P. 1989: Style and changing relations between the individual and society. In: Hodder, I. (ed.): The Meanings of Things. Material Culture and Symbolic Expression. London, 56-63.

Wolfram, S. 2009: Keramik aus einer bandkeramischen Fundschicht: taphonomische und räumliche Analysen (Pottery from a Bandkeramik Finds Layer: Taphonomic and Spatial Analyses). In: StocкнаммеR, P. (ed.): Keramik jenseits von Chronologie. Beiträge der Arbeitsgemeinschaft 'Theorie in der Archäologie' bei der Tagung des West- und Süddeutschen Verbandes für Altertumsforschung e.V. in Xanten, 7.-8. Funi 2006. Internationale Archäologie Arbeitsgemainschaft. Symposium. Tagung. Kongress Band 14. Rahden/Westf., 13-27.

ZALAI-GAÁL, I. 2007a: Von Lengyel bis Mórágy. Die spätneolithische Grabkeramik in Südtransdanubien aus den alten Ausgrabungen. I. Analyse. A Wosinsky Mór Múzeum Évkönyve 65, 285-334.

ZALAI-GAÁL， I. 2007b: Zengővárkony-Svodín-Friebritz: Zu den chronologischen Beziehungen zwischen den territorialen Gruppen der Lengyel-Kultur aufgrund der Gräberfeldanalyse. In: Kozıowski, J. K. - Raczky, P. (eds.): The Lengyel, Polgár and Related Cultures in the Middle/Late Neolithic in Central Europe. Kraków, 147-184. 

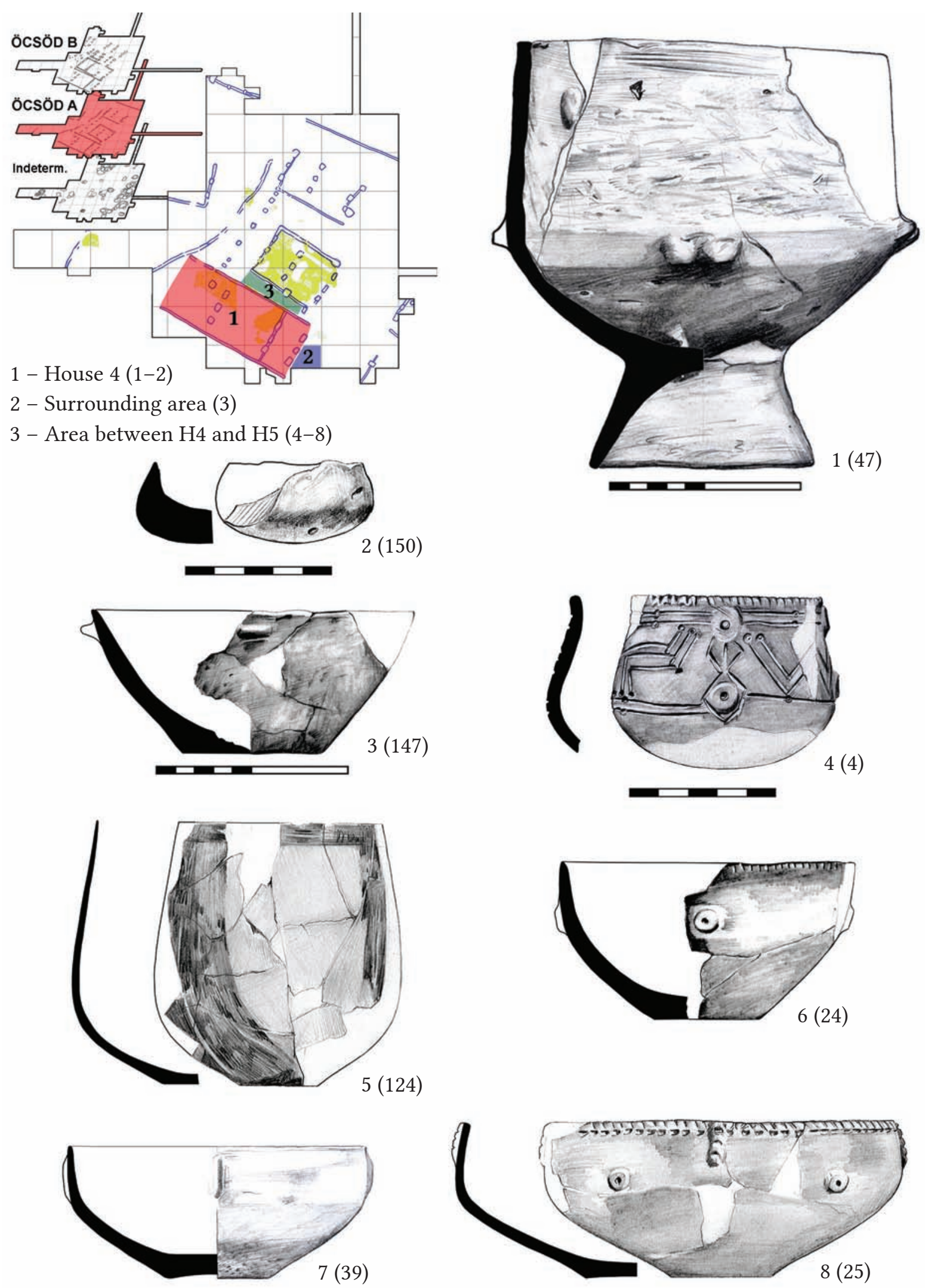

Fig. 30. Refitted vessels from the early occupation at Ȯcsöd-Kováshalom. 

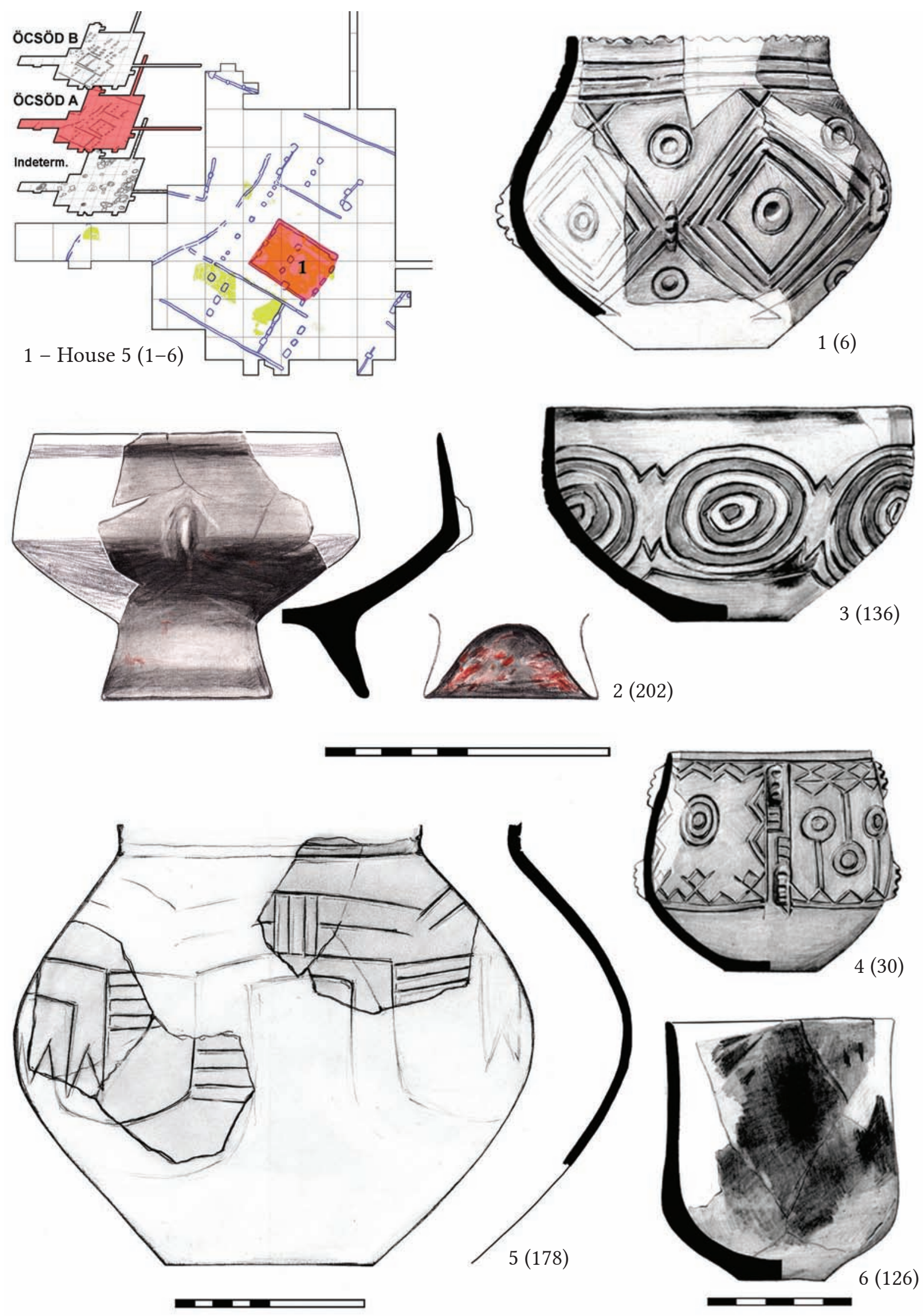

Fig. 31. Refitted vessels from the early occupation at Öcsöd-Kováshalom. 

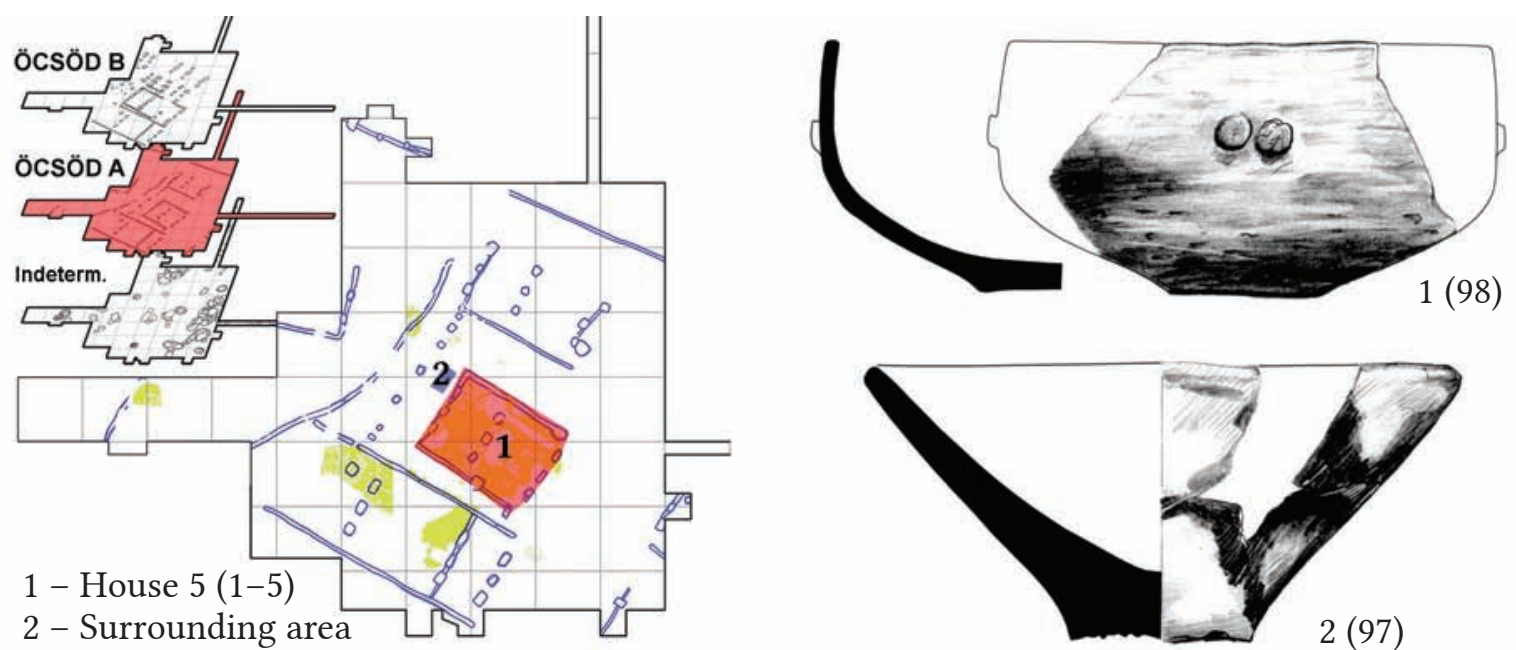

$$
(6-7)
$$
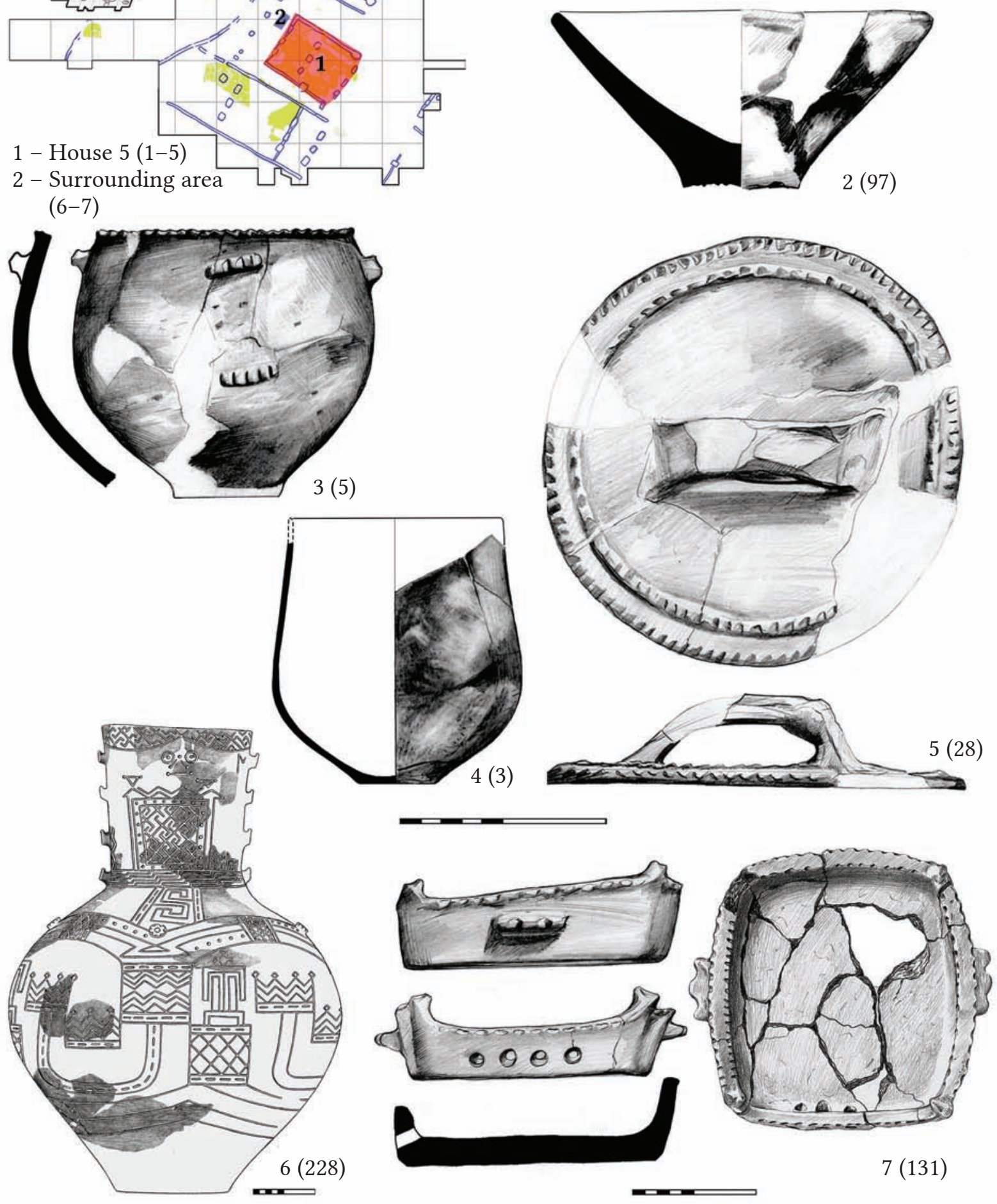

Fig. 32. Refitted vessels from the early occupation at Öcsöd-Kováshalom. 


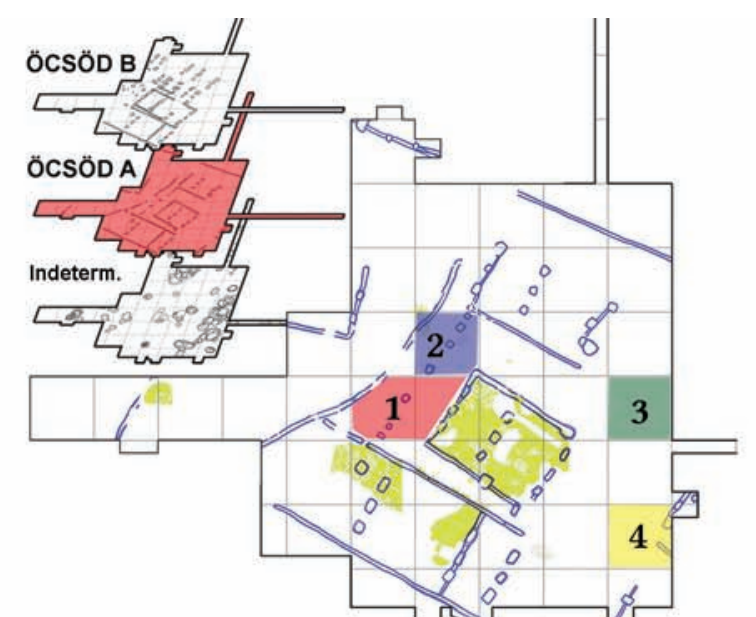

1 - Area behind H5 (1-3)

2 - Area behind H5 (4-7)

3 - Area in front of $\mathrm{H} 8(8)$

4 - South-east area (9)
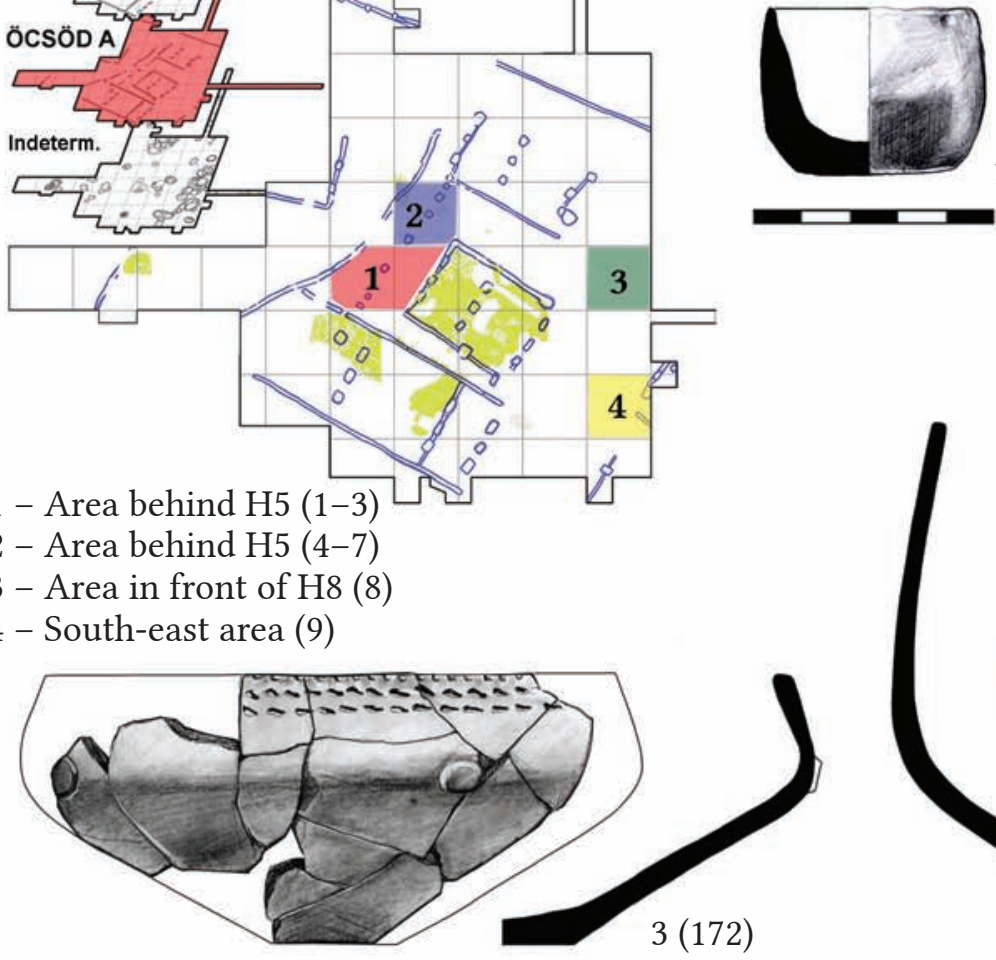

$1(7)$
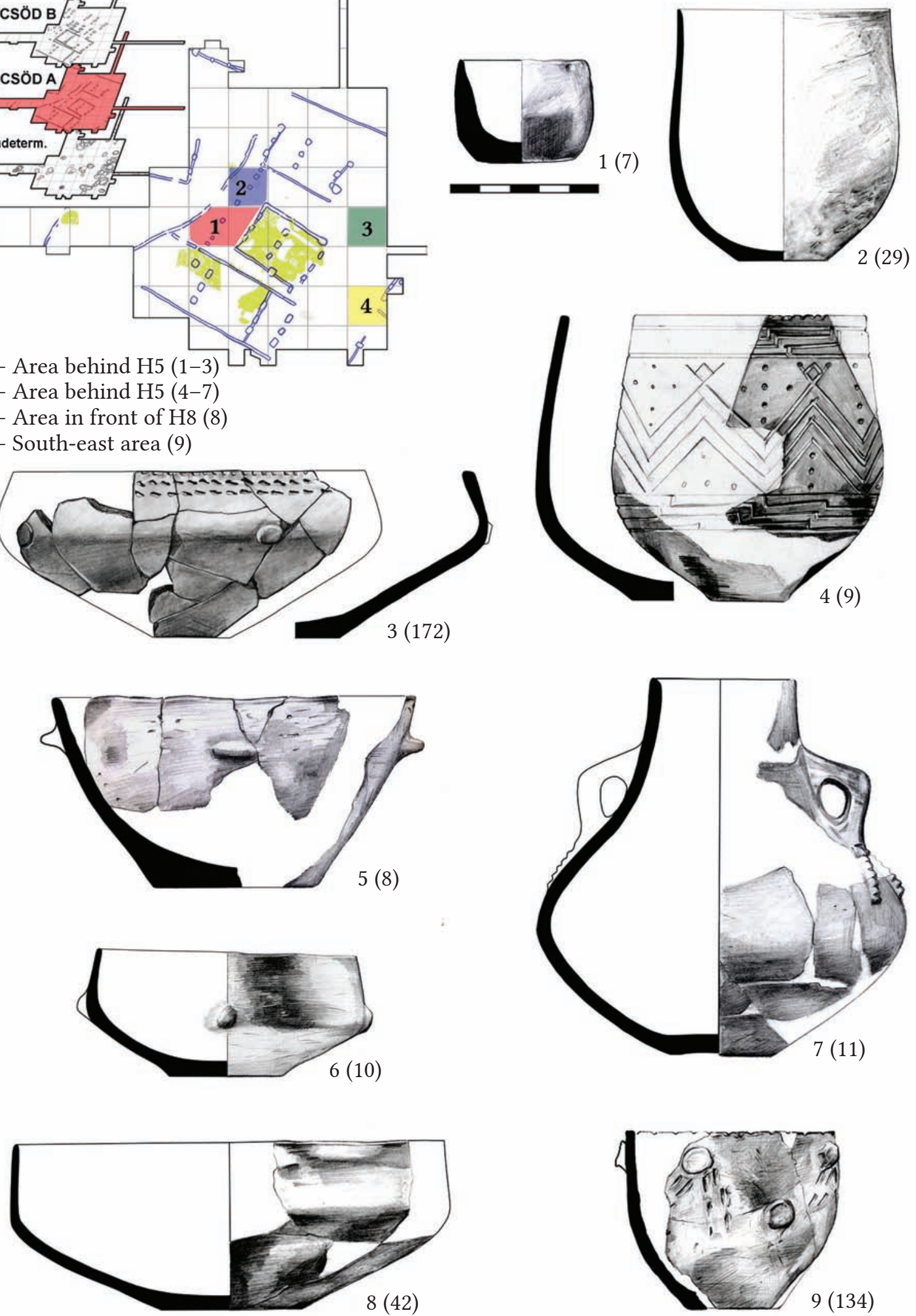

Fig. 33. Refitted vessels from the early occupation at Öcsöd-Kováshalom. 

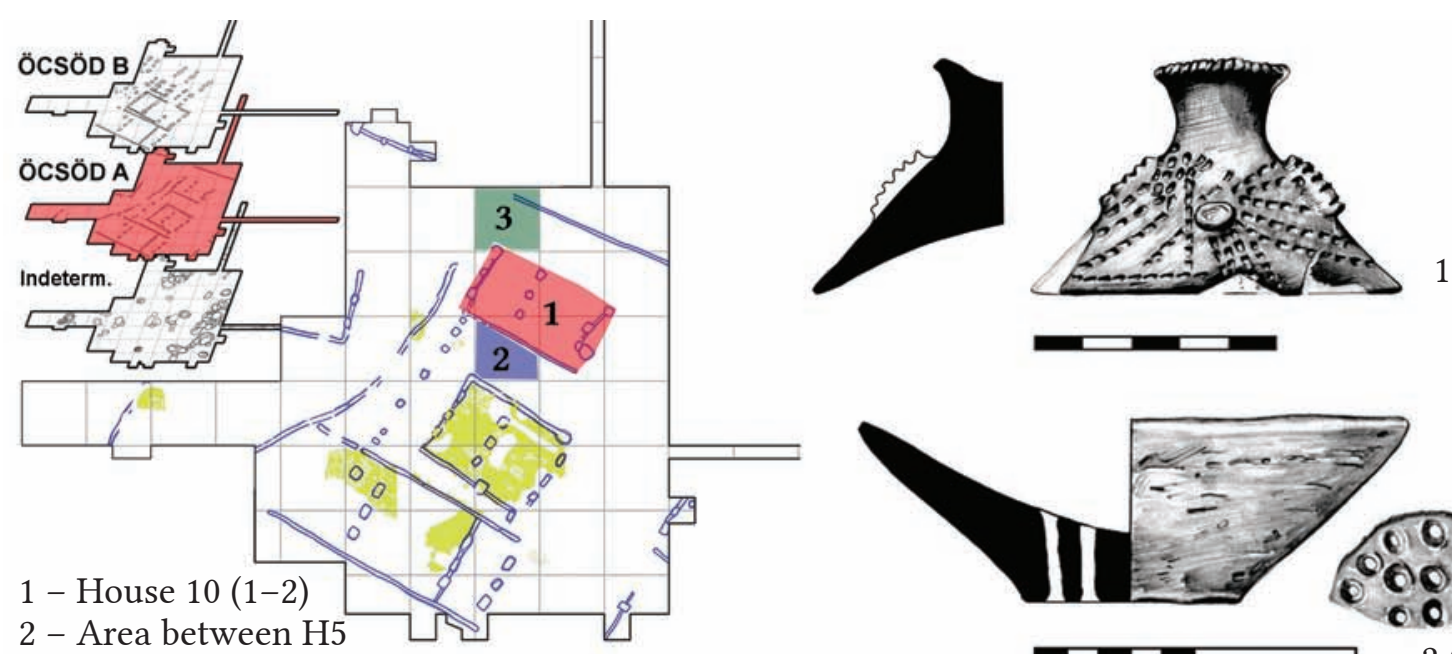

2 - Area between $\mathrm{H}$ and $\mathrm{H} 10$ (3-6)

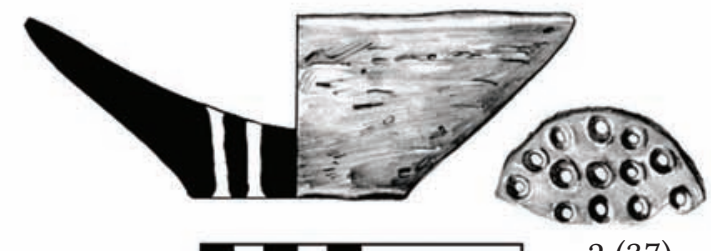

3 - Area behind H10 (7)
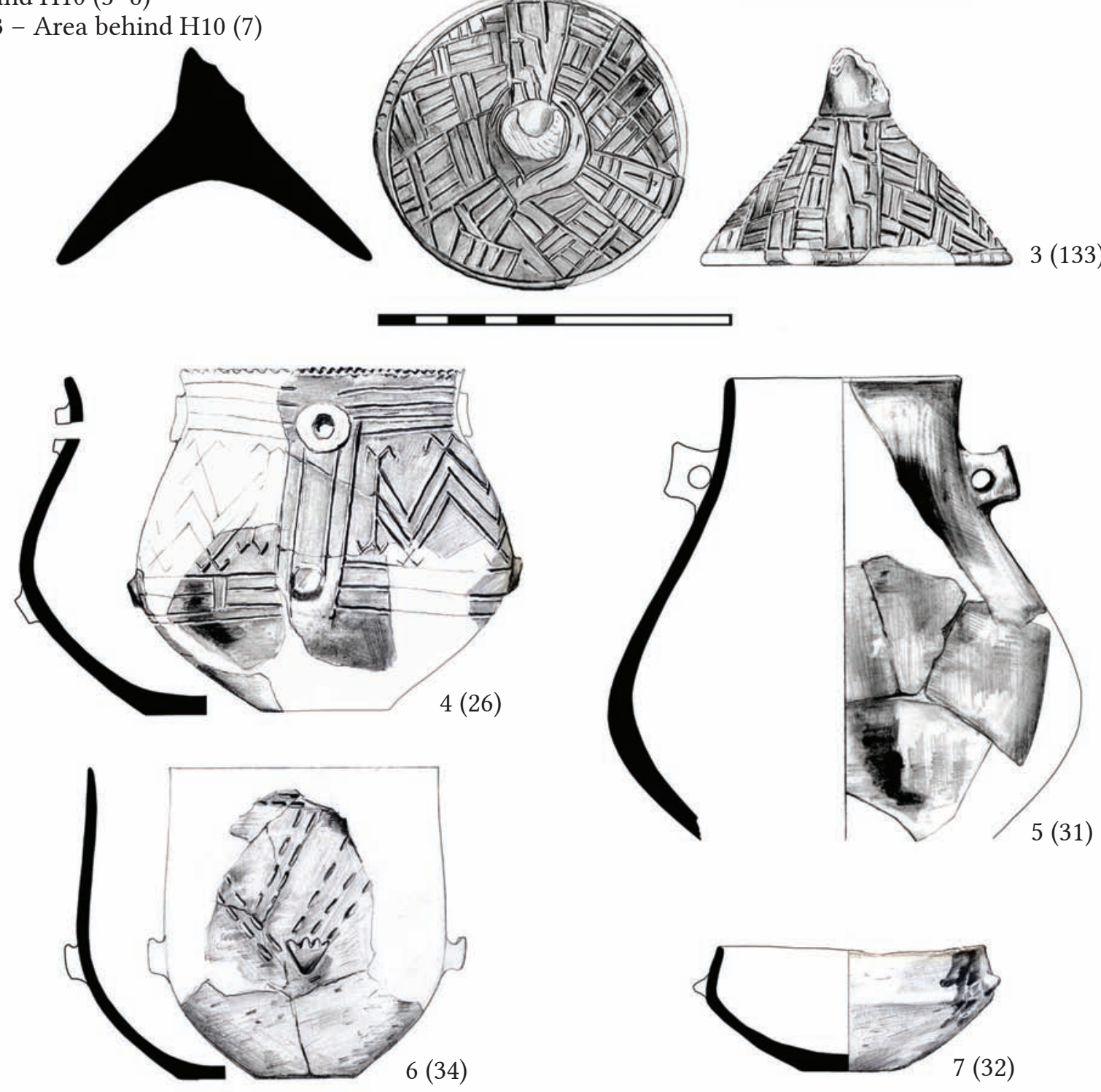

Fig. 34. Refitted vessels from the early occupation at Ȯcsöd-Kováshalom. 

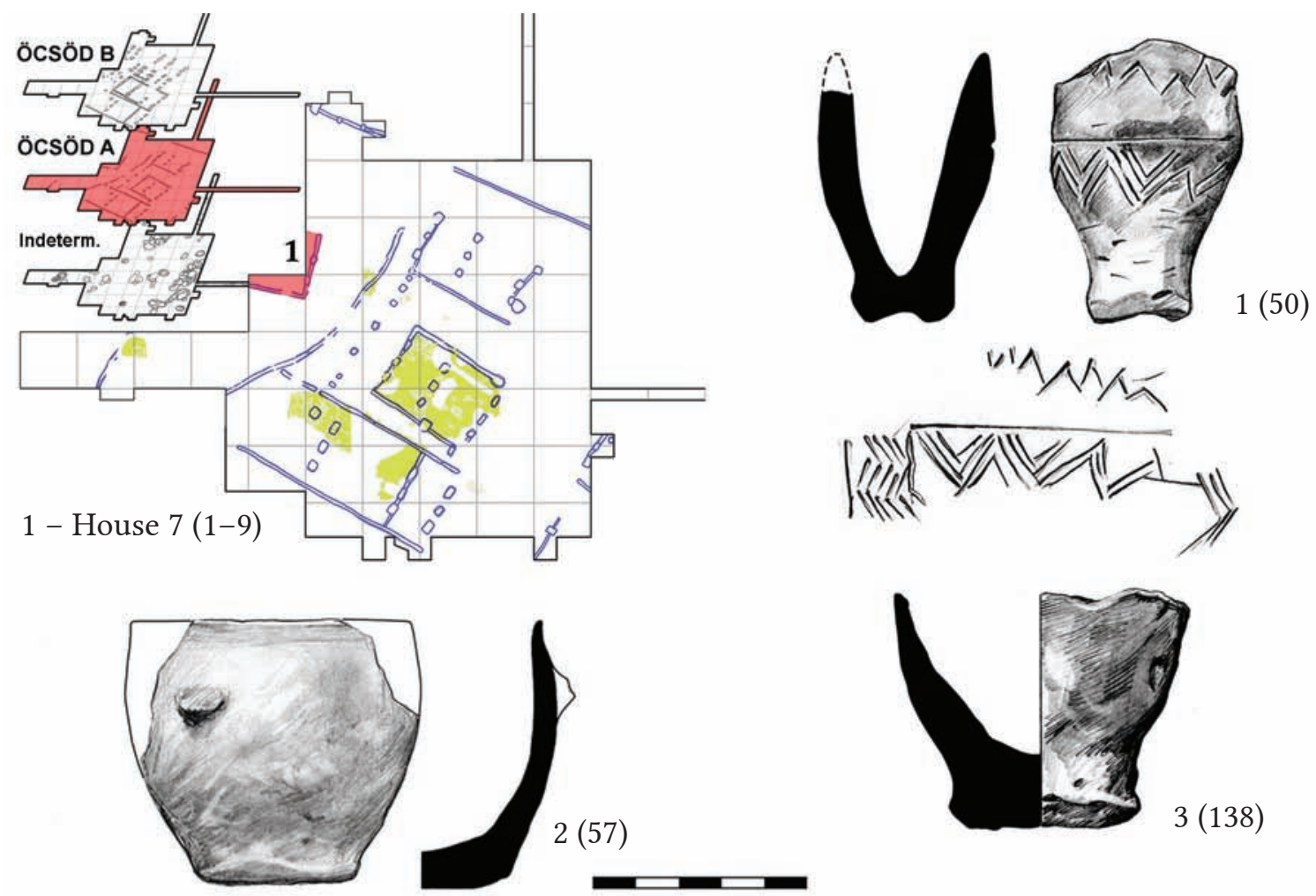

$2(57)$

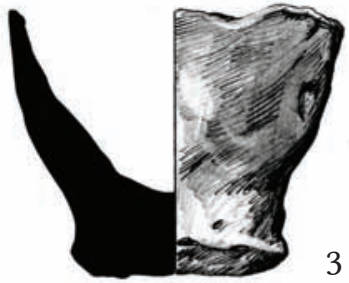

$3(138)$
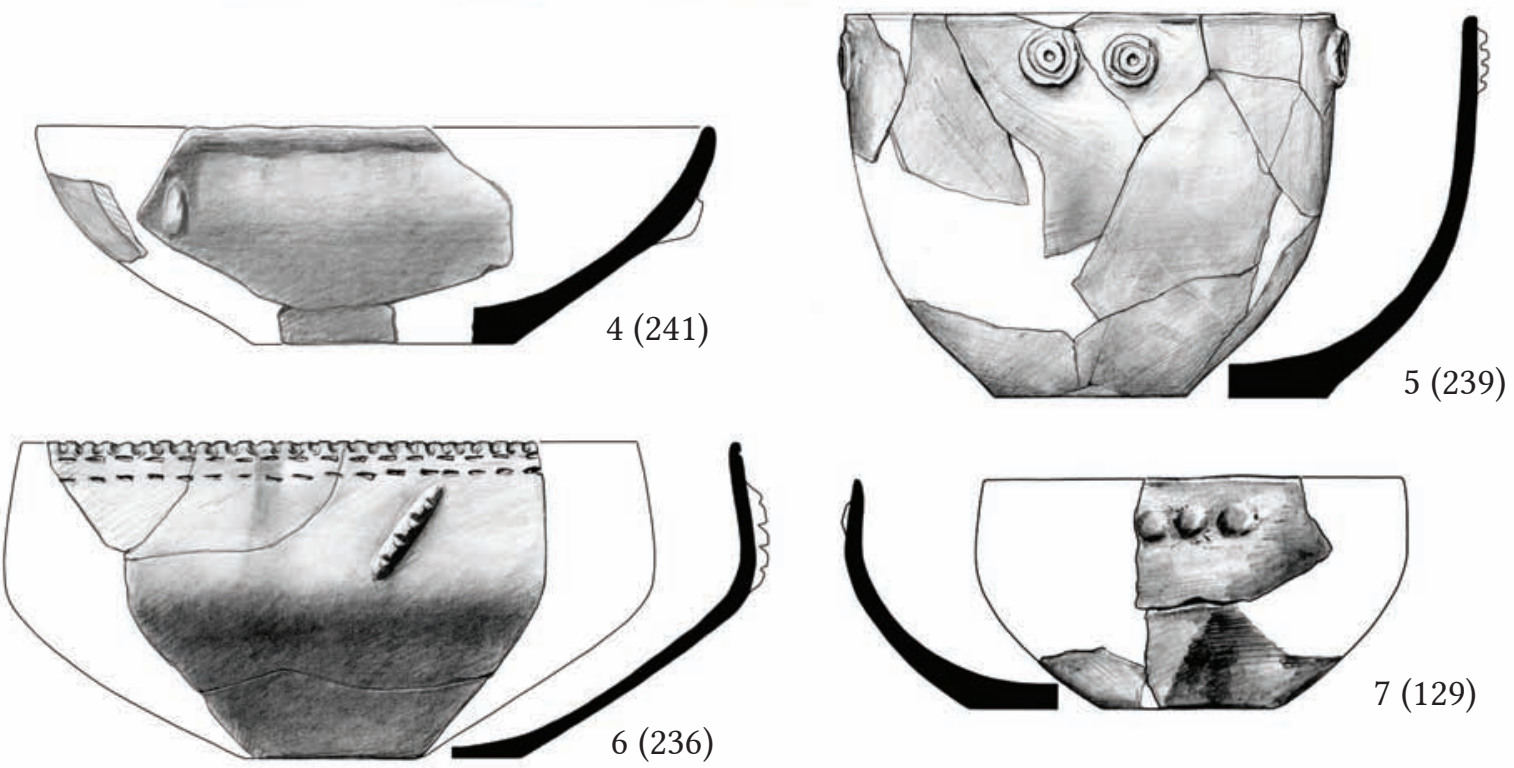

$7(129)$
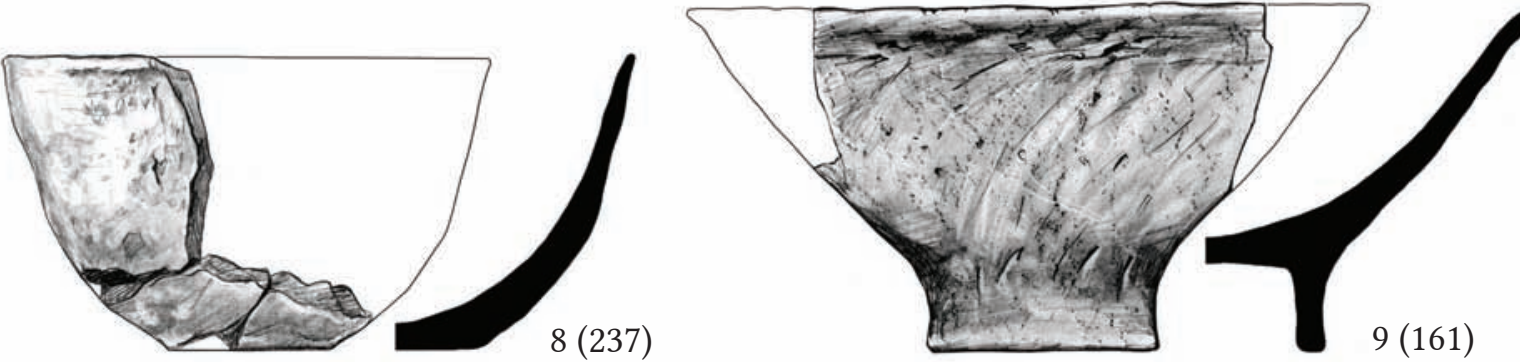

Fig. 35. Refitted vessels from the early occupation at Öcsöd-Kováshalom. 

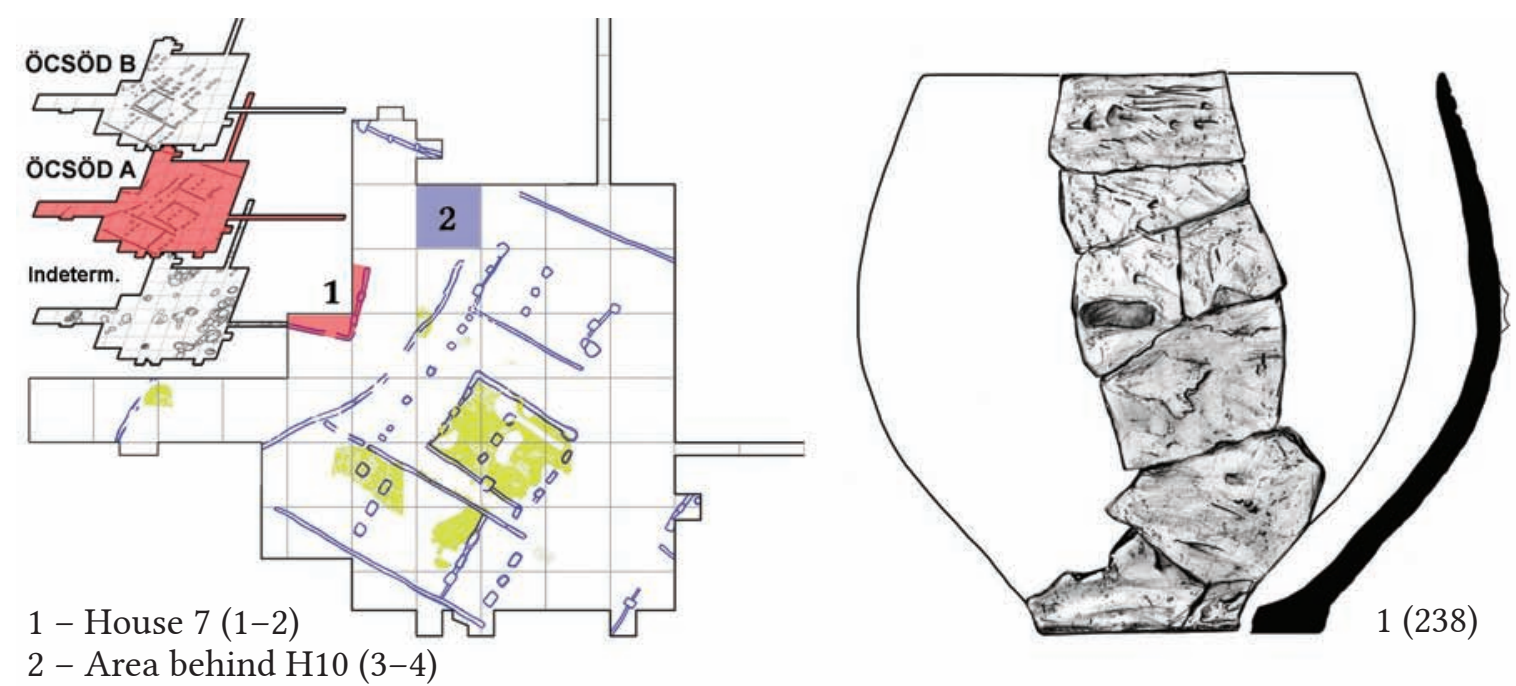

2 - Area behind H10 (3-4)
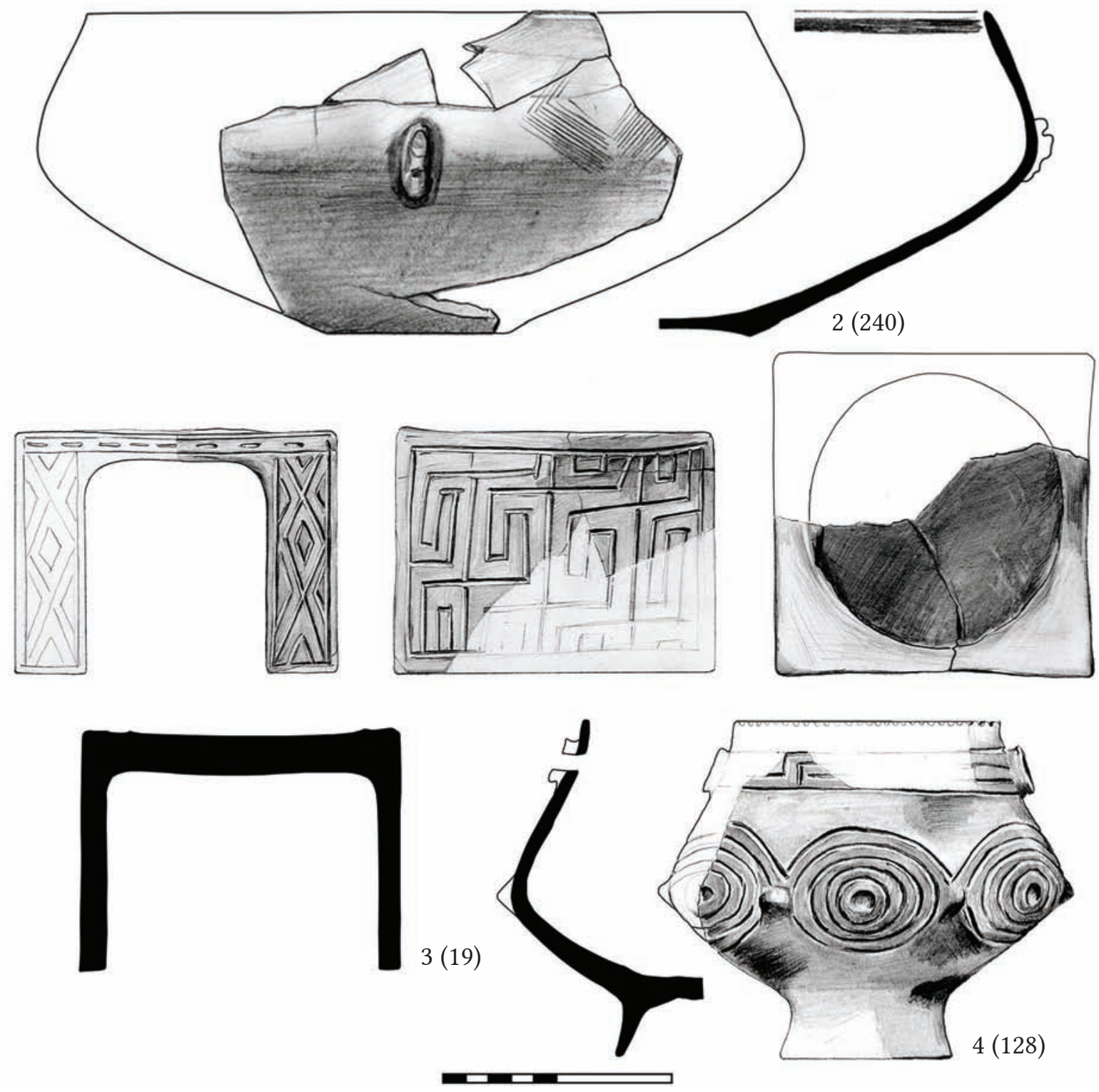

Fig. 36. Refitted vessels from the early occupation at Öcsöd-Kováshalom. 

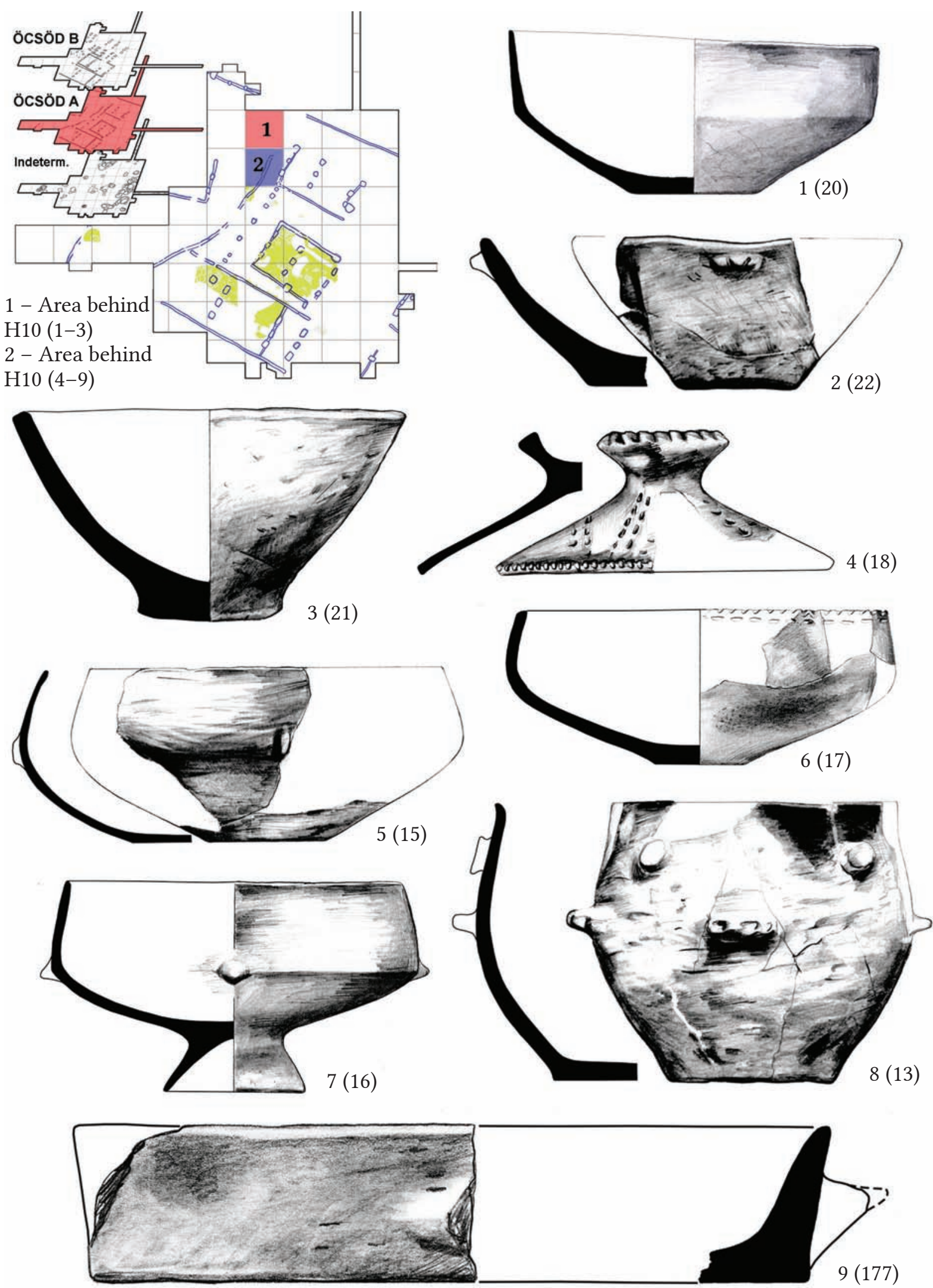

Fig. 37. Refitted vessels from the early occupation at Öcsöd-Kováshalom. 

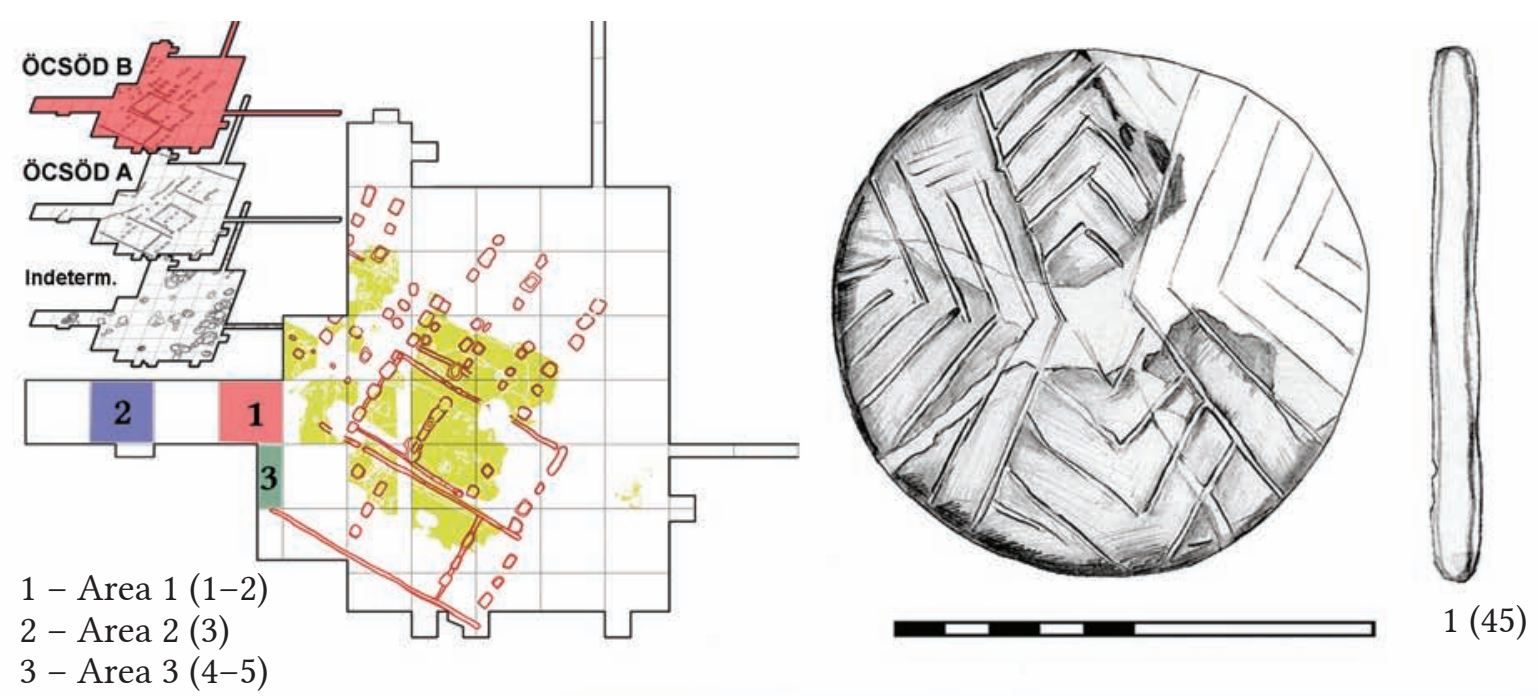

- Area $3(4-5)$

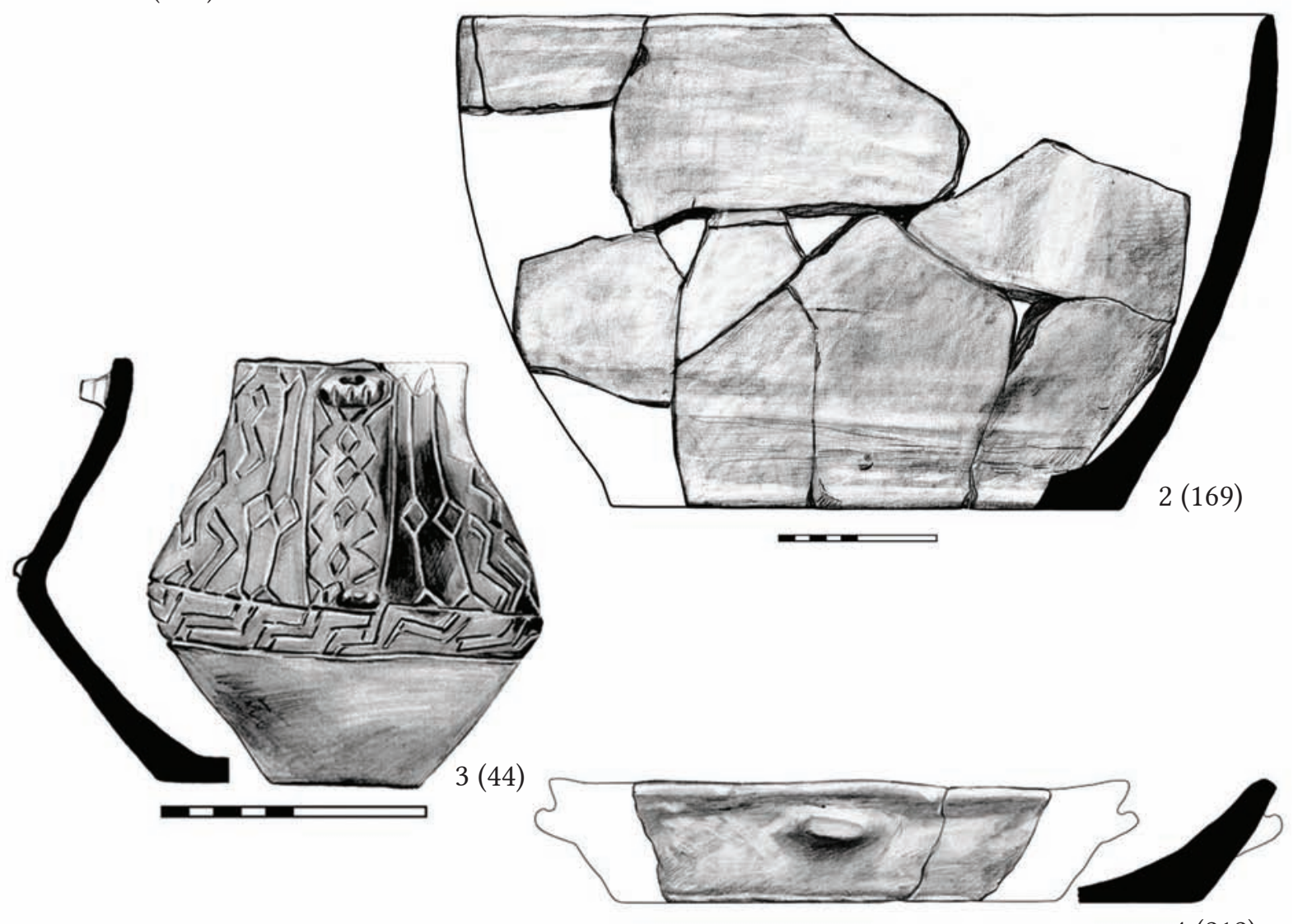

$4(212)$

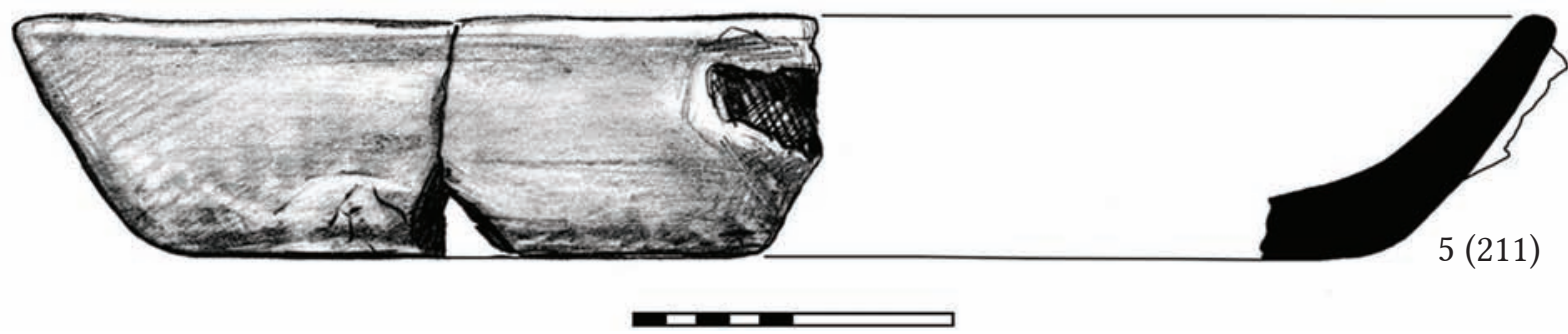

Fig. 38. Refitted vessels from the late occupation at Öcsöd-Kováshalom. 

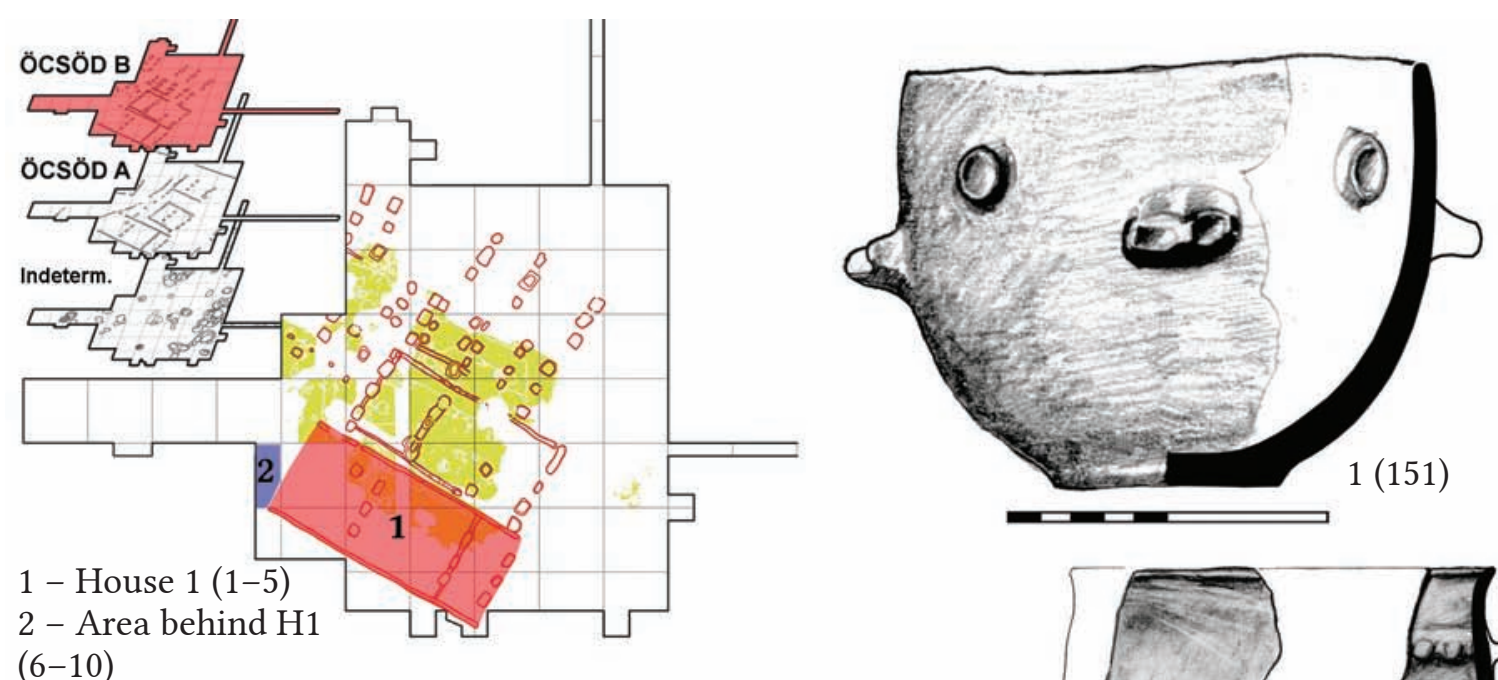

$(6-10)$
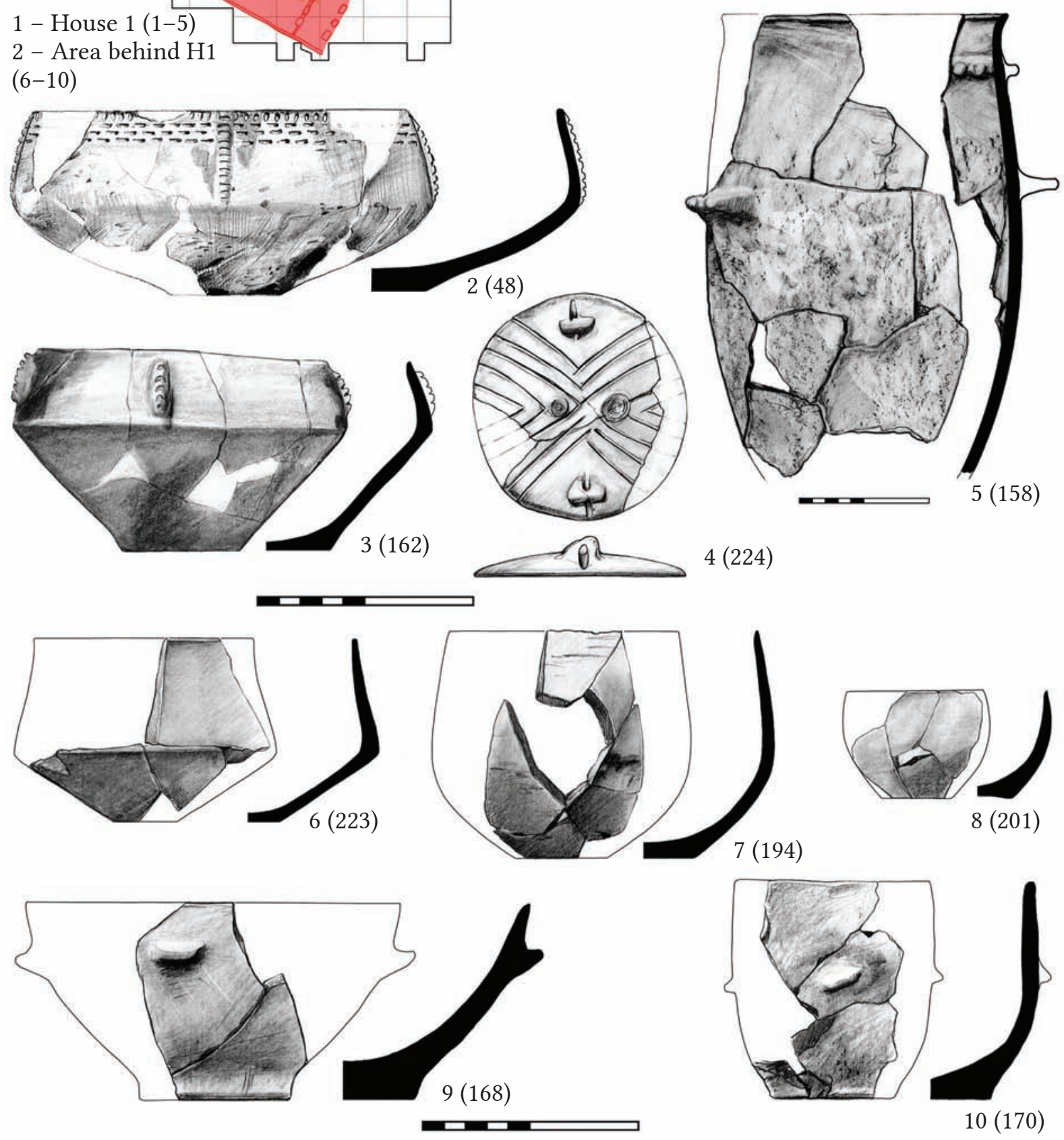

Fig. 39. Refitted vessels from the late occupation at Öcsöd-Kováshalom. 

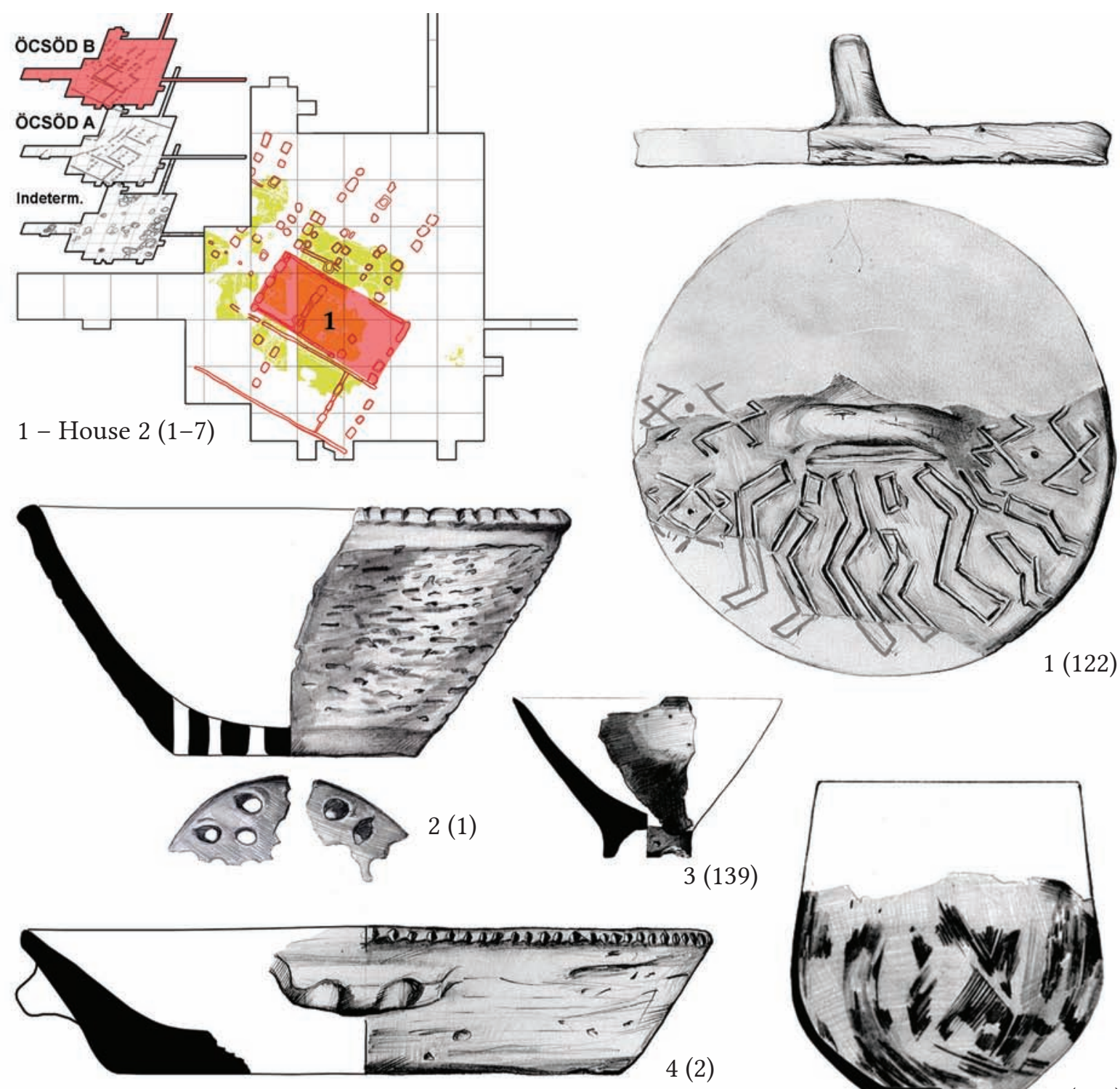

$1(122)$

$4(2)$
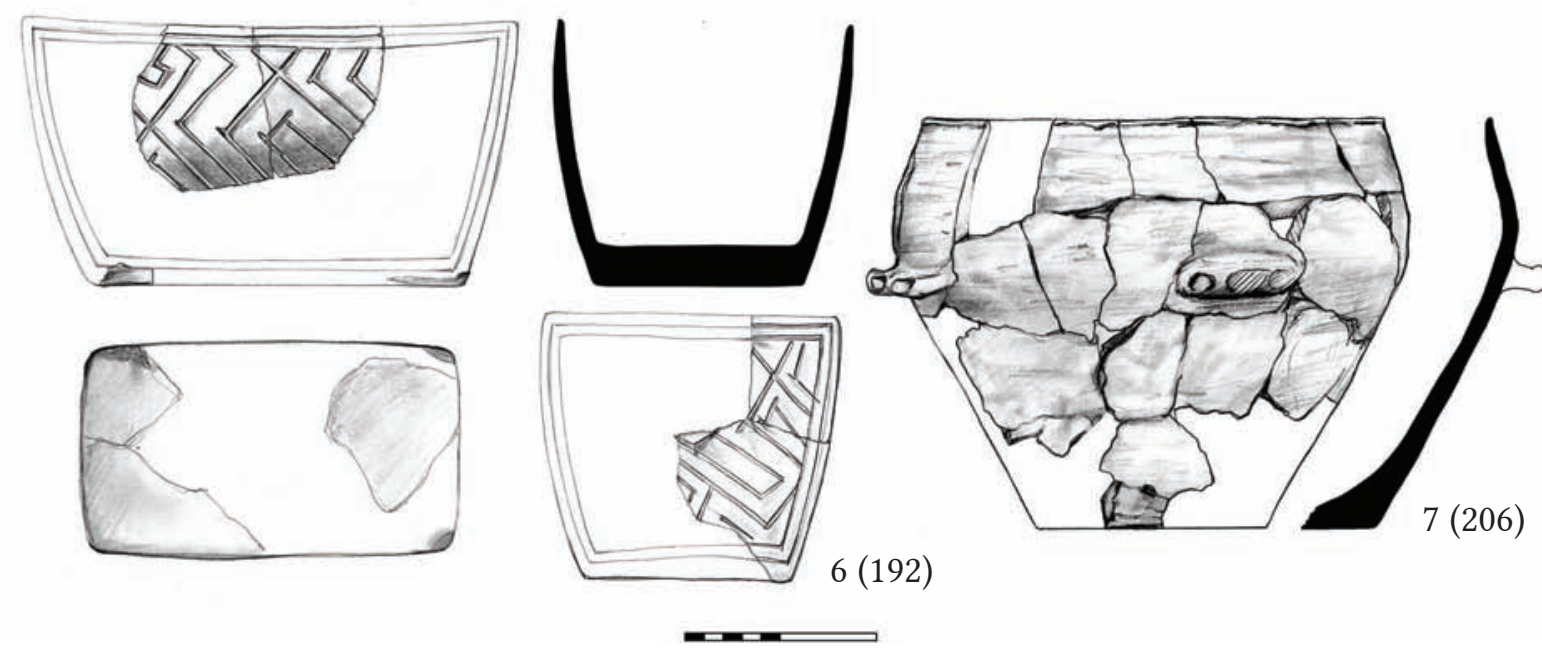

Fig. 40. Refitted vessels from the late occupation at Öcsöd-Kováshalom. 

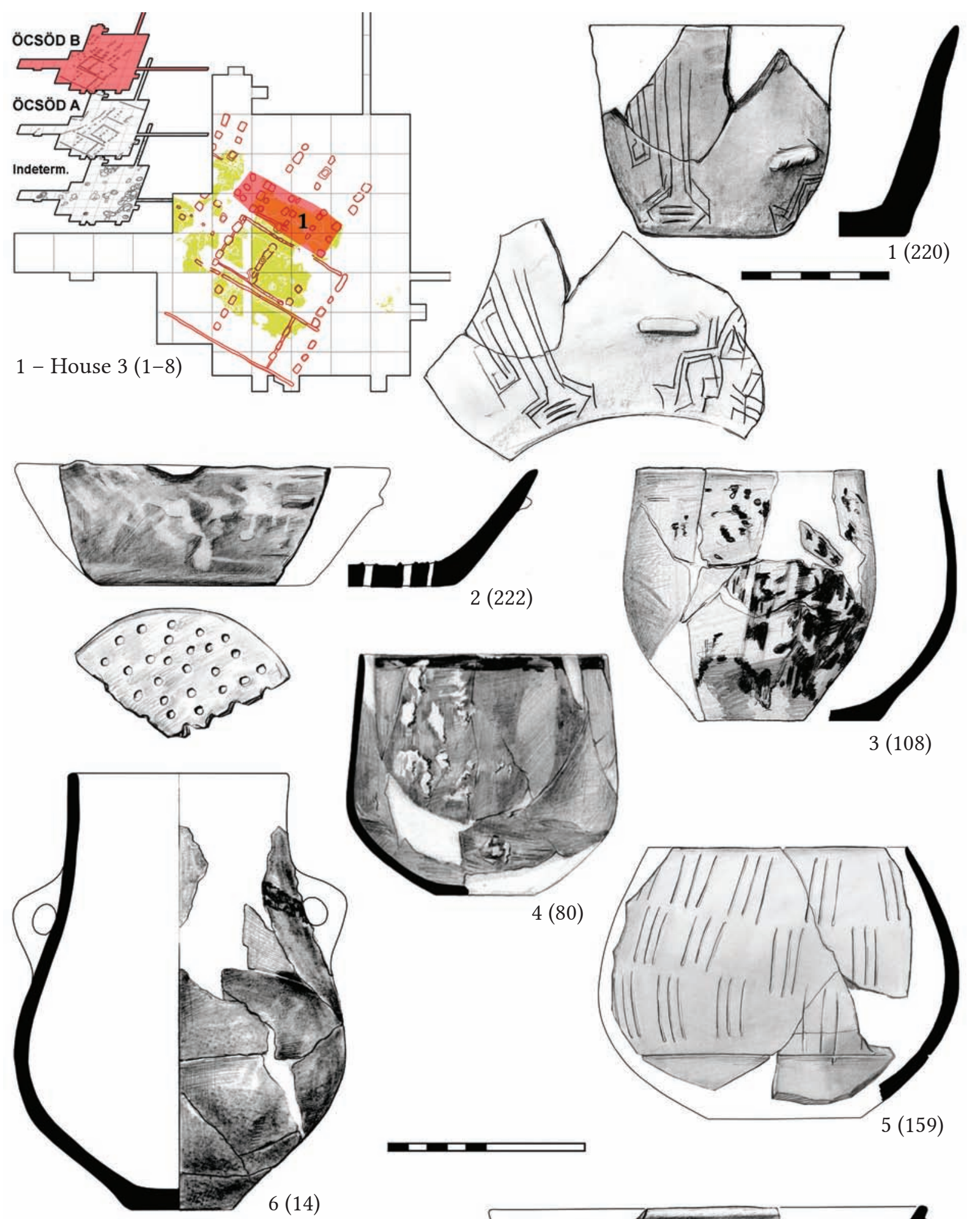

$2(222)$
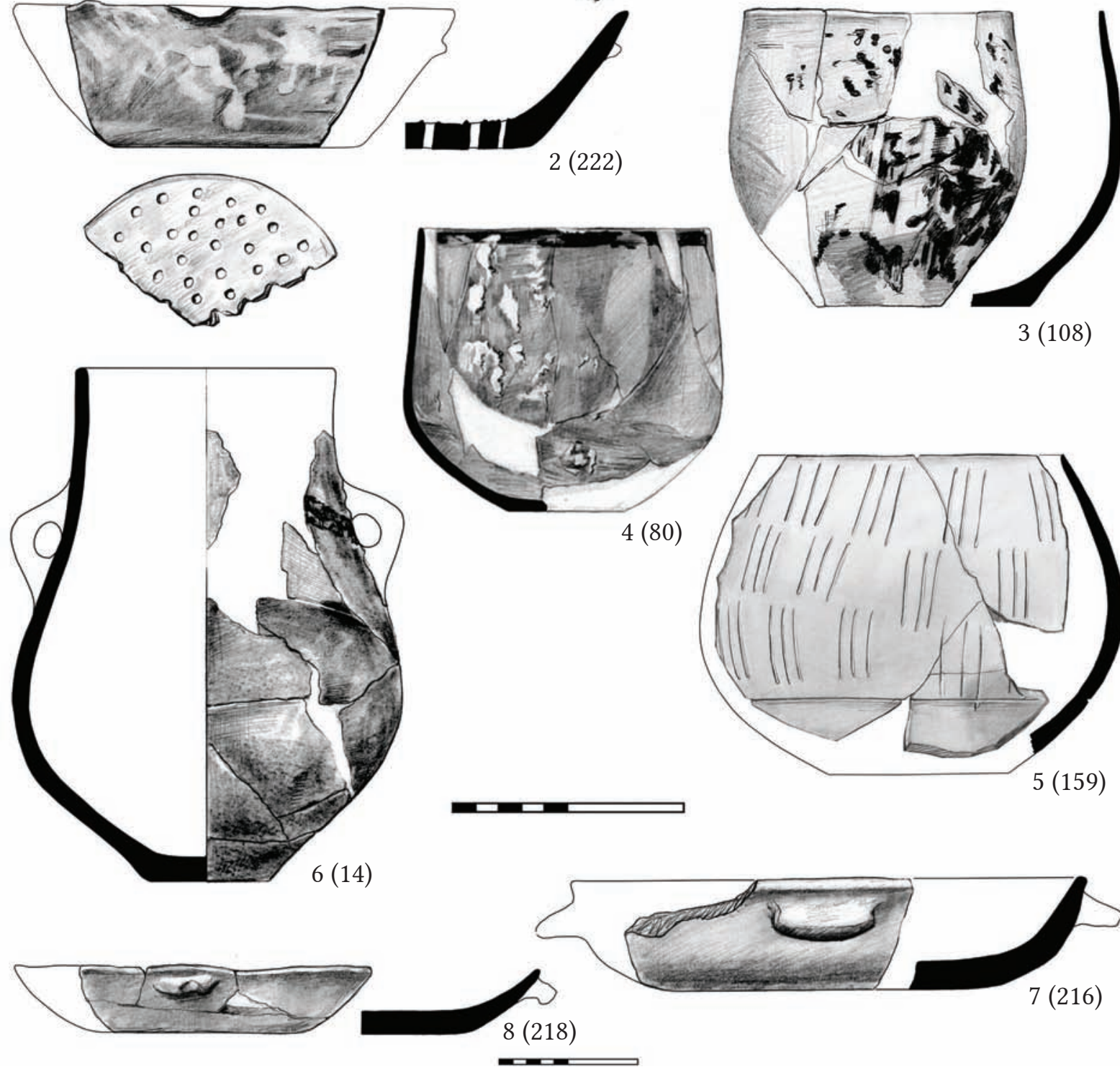

Fig. 41. Refitted vessels from the late occupation at Öcsöd-Kováshalom. 

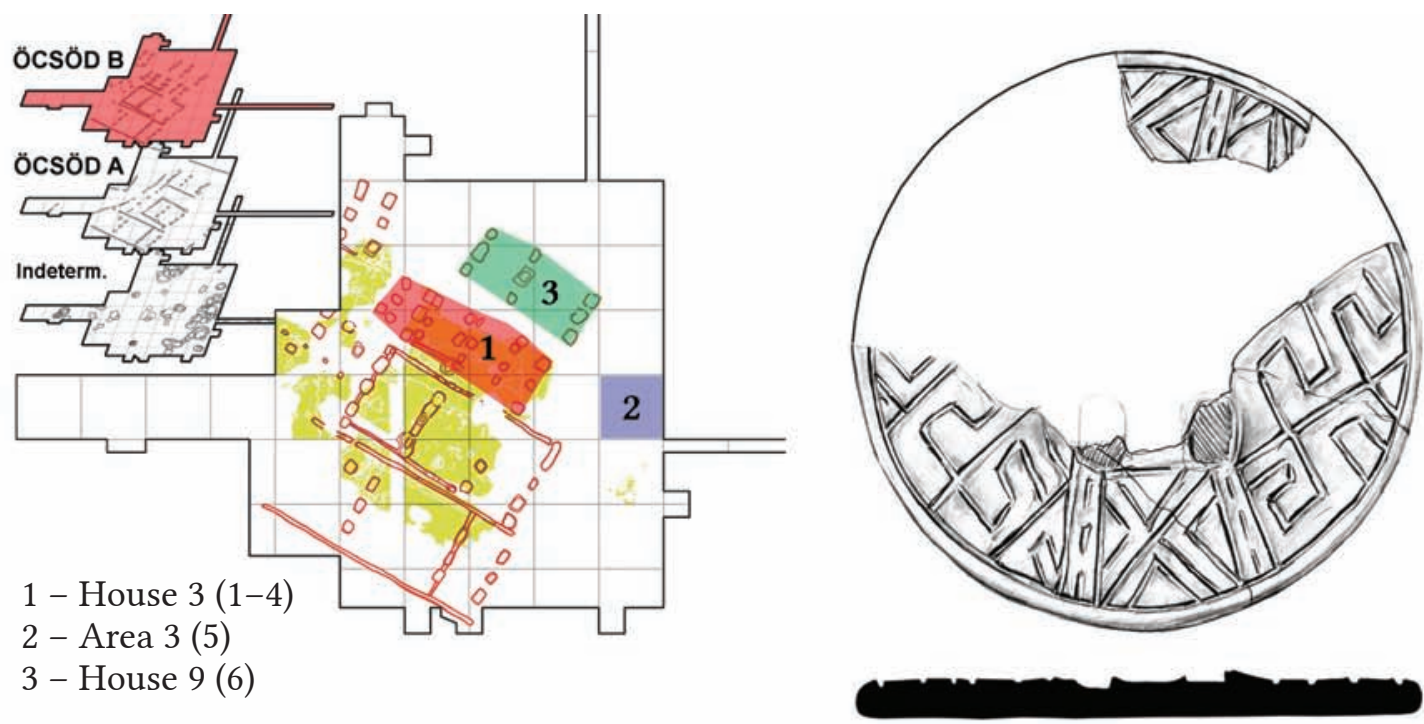

$1(198)$
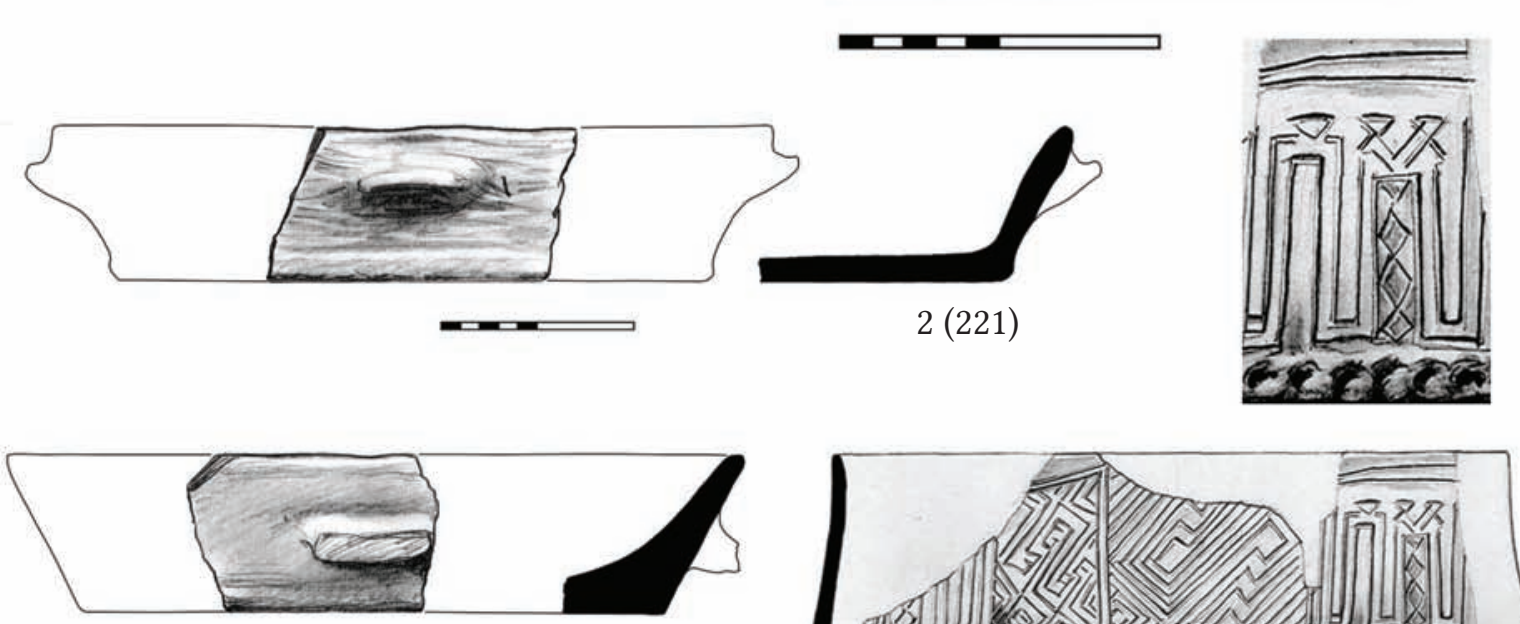

$3(219)$
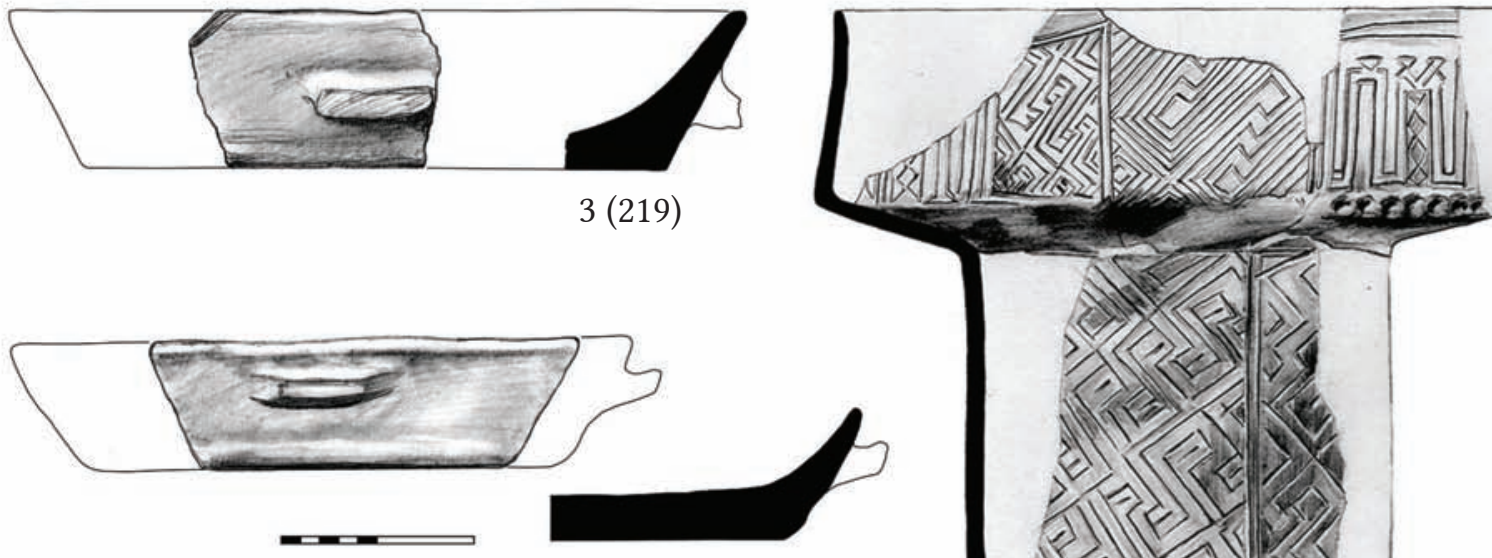

$4(217)$

$5(41)$

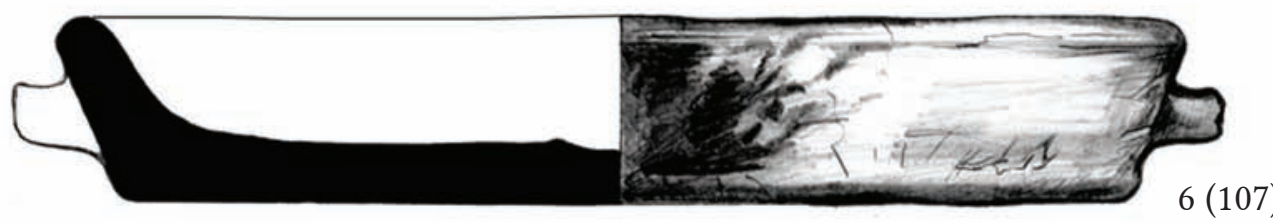

Fig. 42. Refitted vessels from the late occupation at Öcsöd-Kováshalom. 

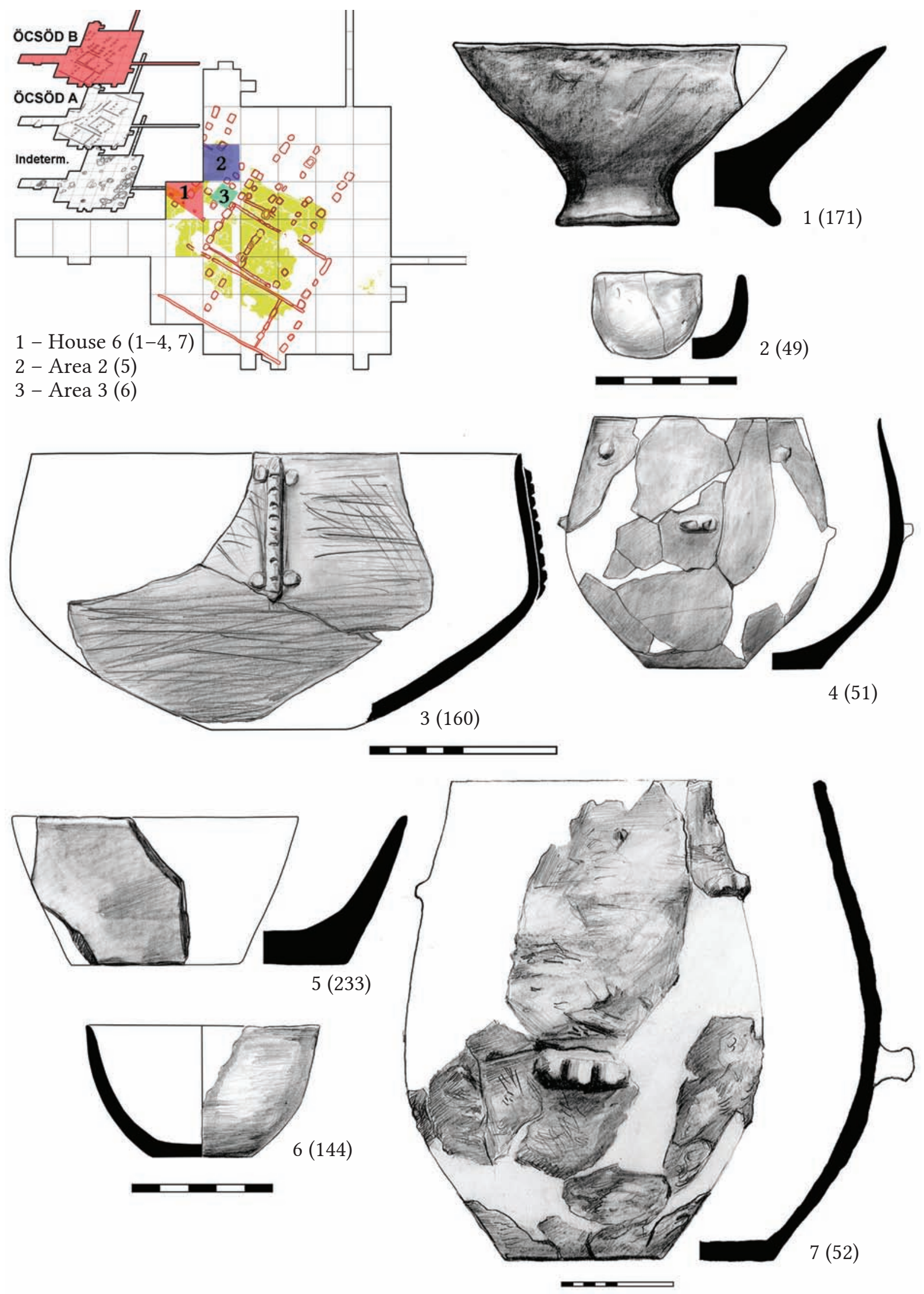

Fig. 43. Refitted vessels from the late occupation at Öcsöd-Kováshalom. 

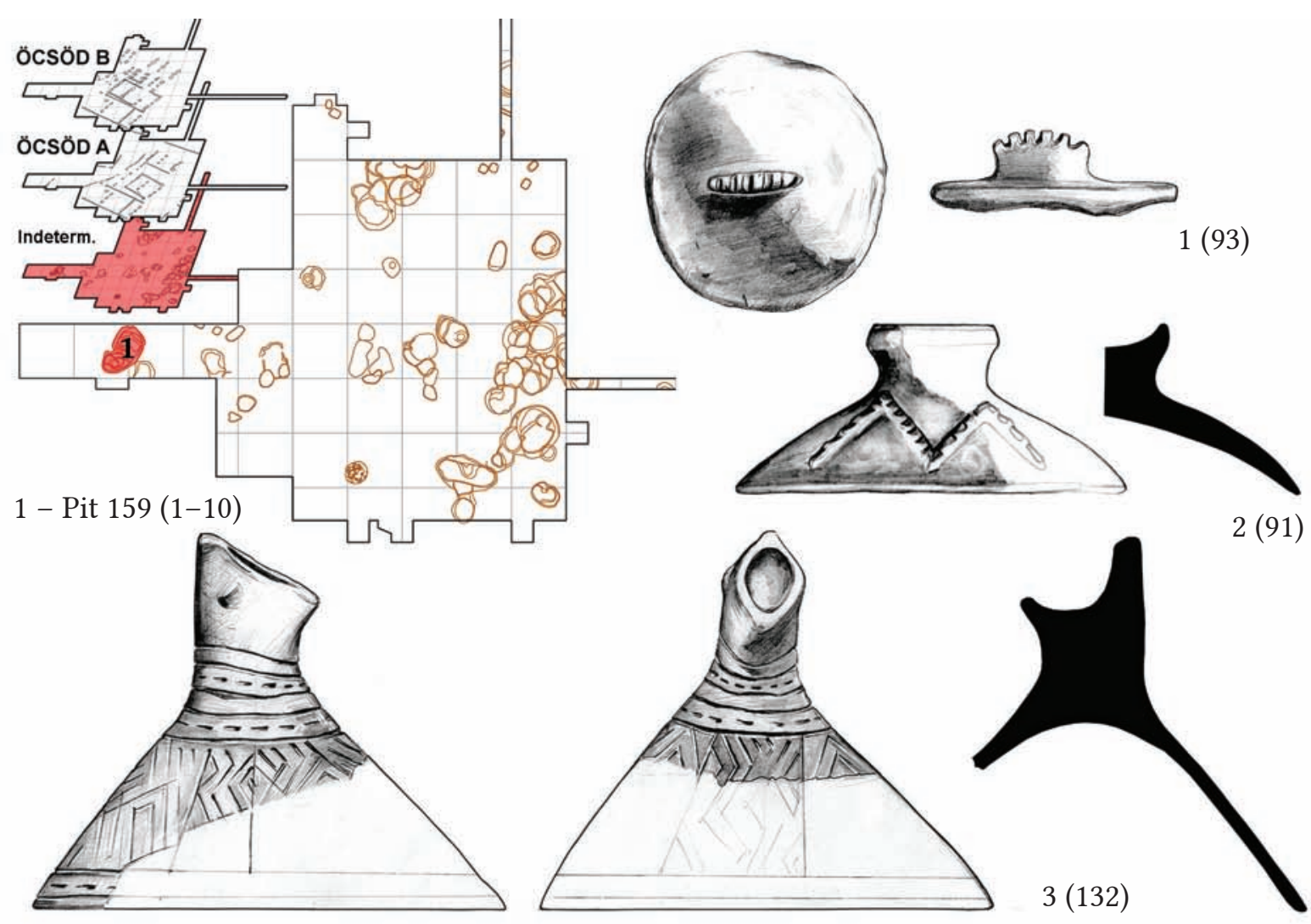

$2(91)$
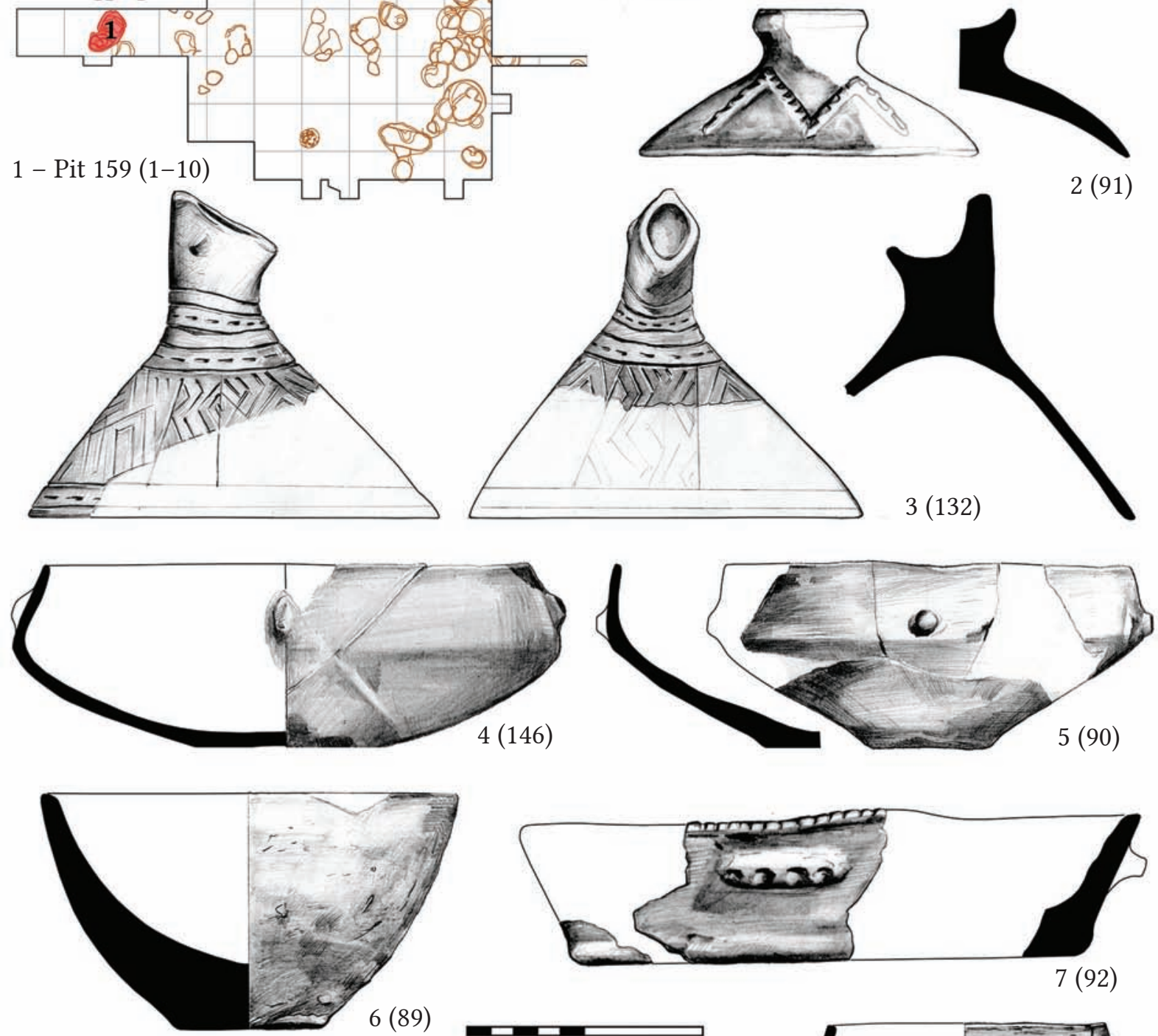

$3(132)$

$4(146)$
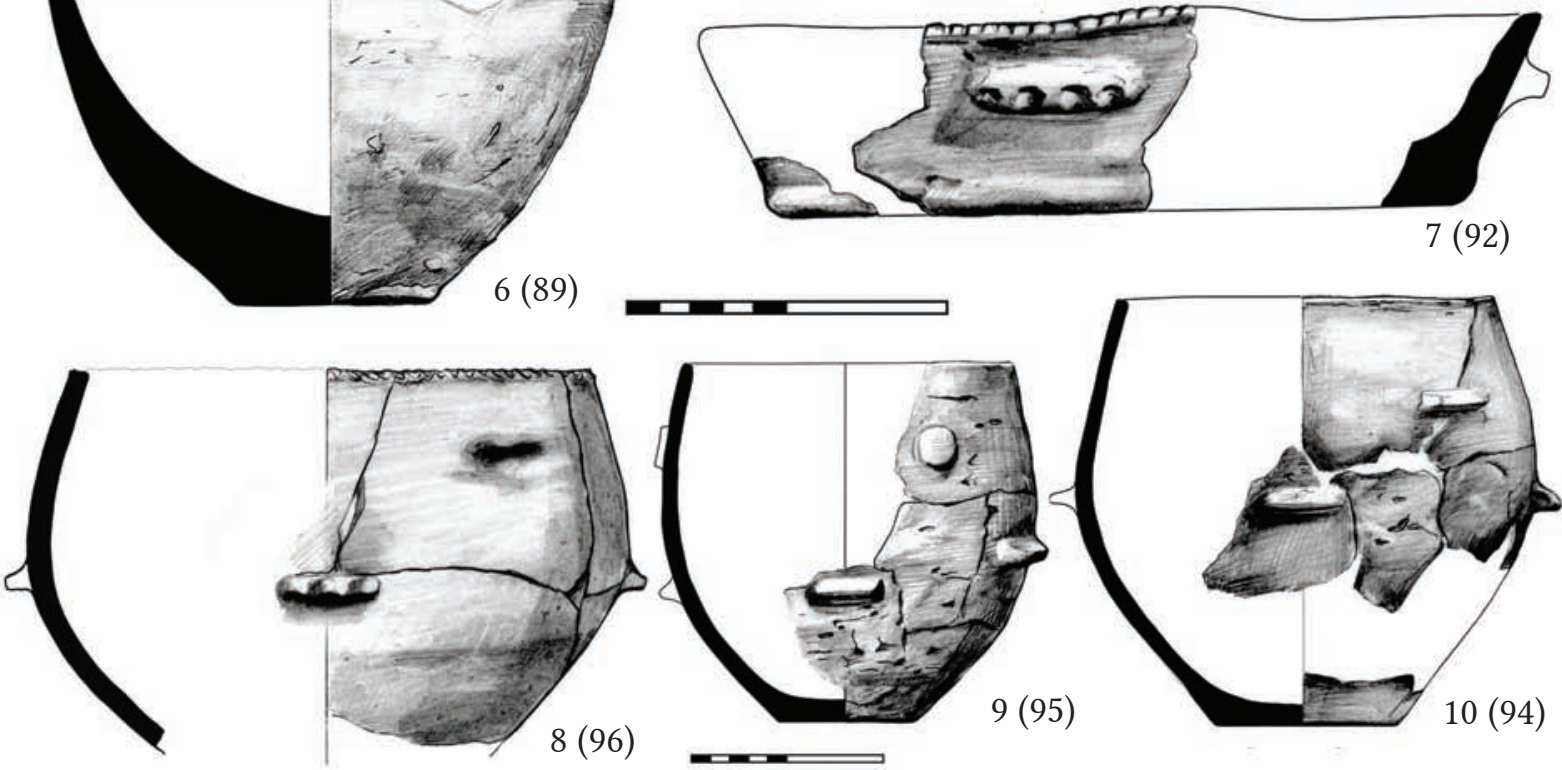

Fig. 44. Refitted vessels from the features dug into the prehistoric soil at Öcsöd-Kováshalom. 

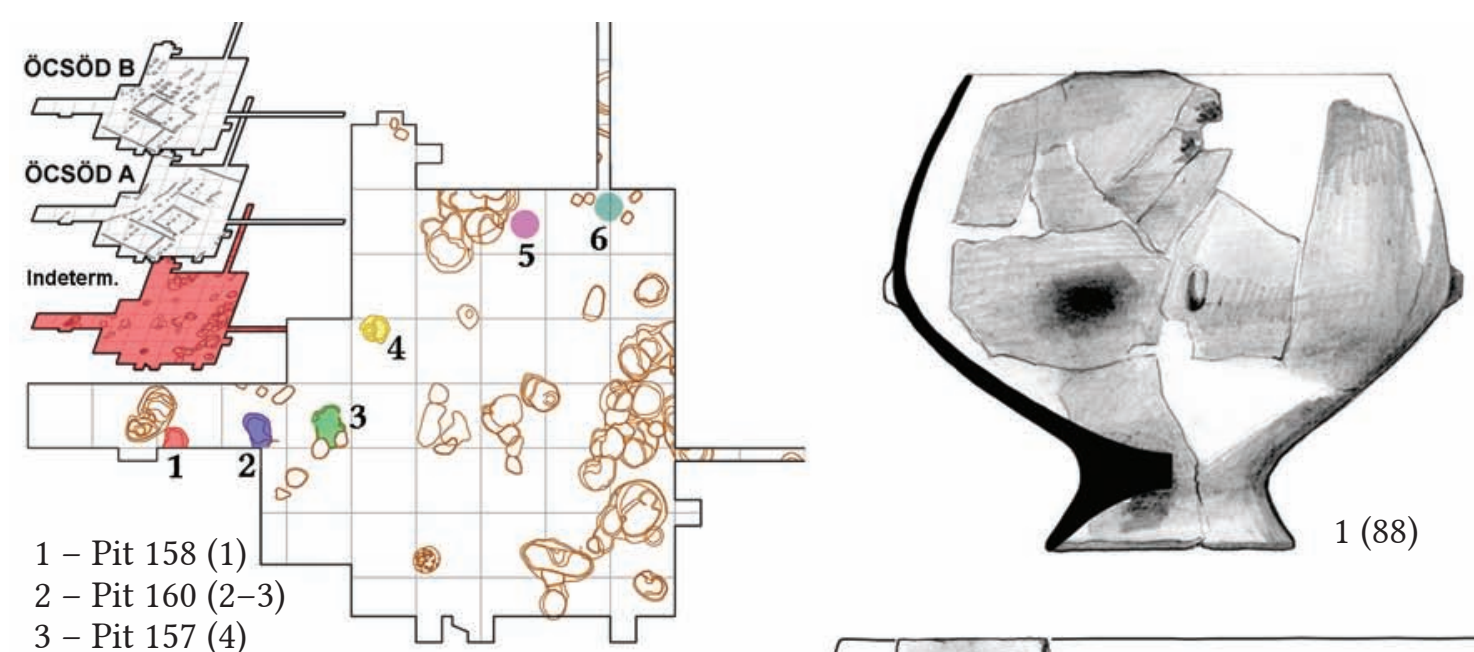

3 - Pit $157(4)$

4 - Pit $106(5)$

5 - Area $5(6)$

6 - Pit $3(7)$
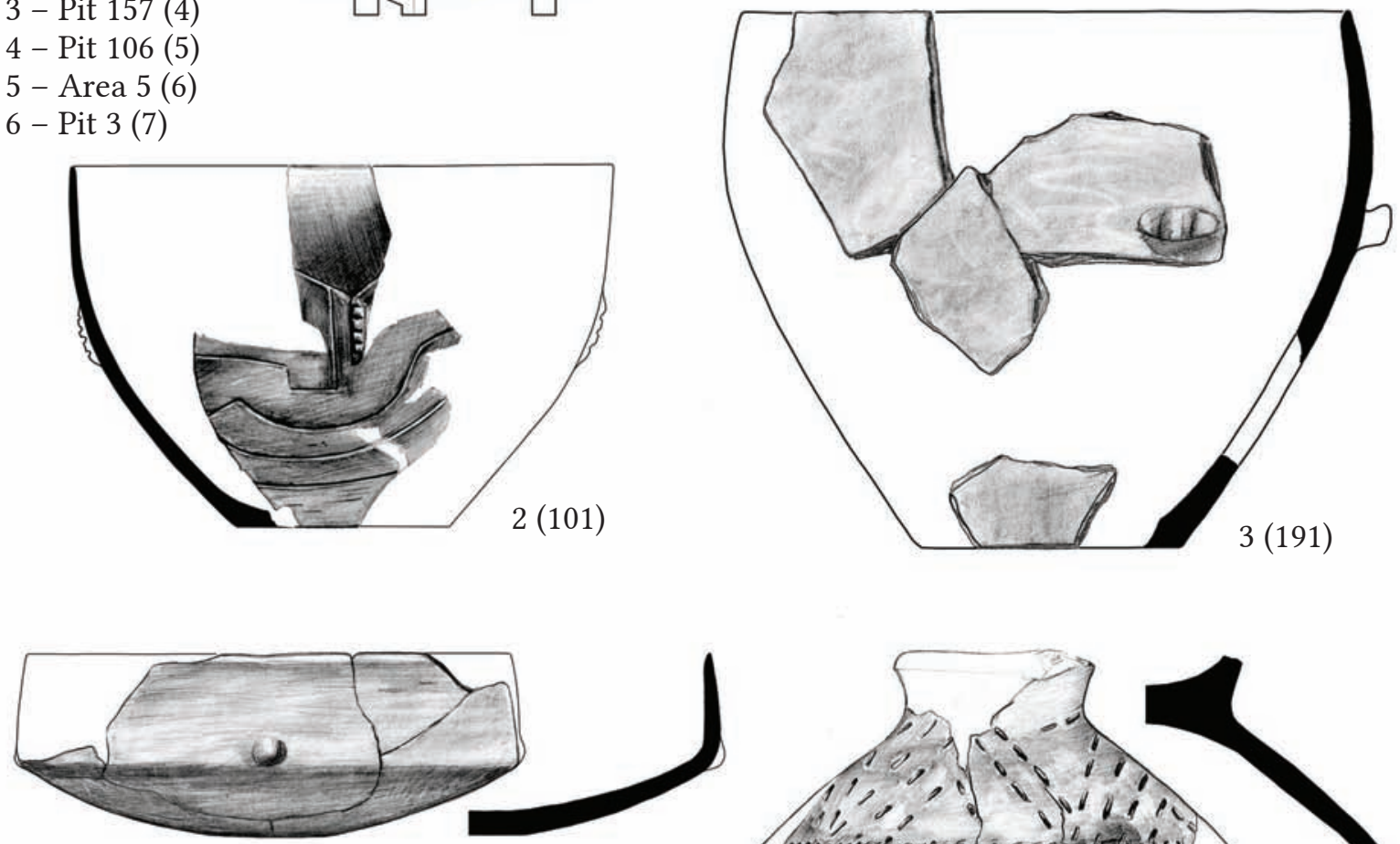

$4(190)$
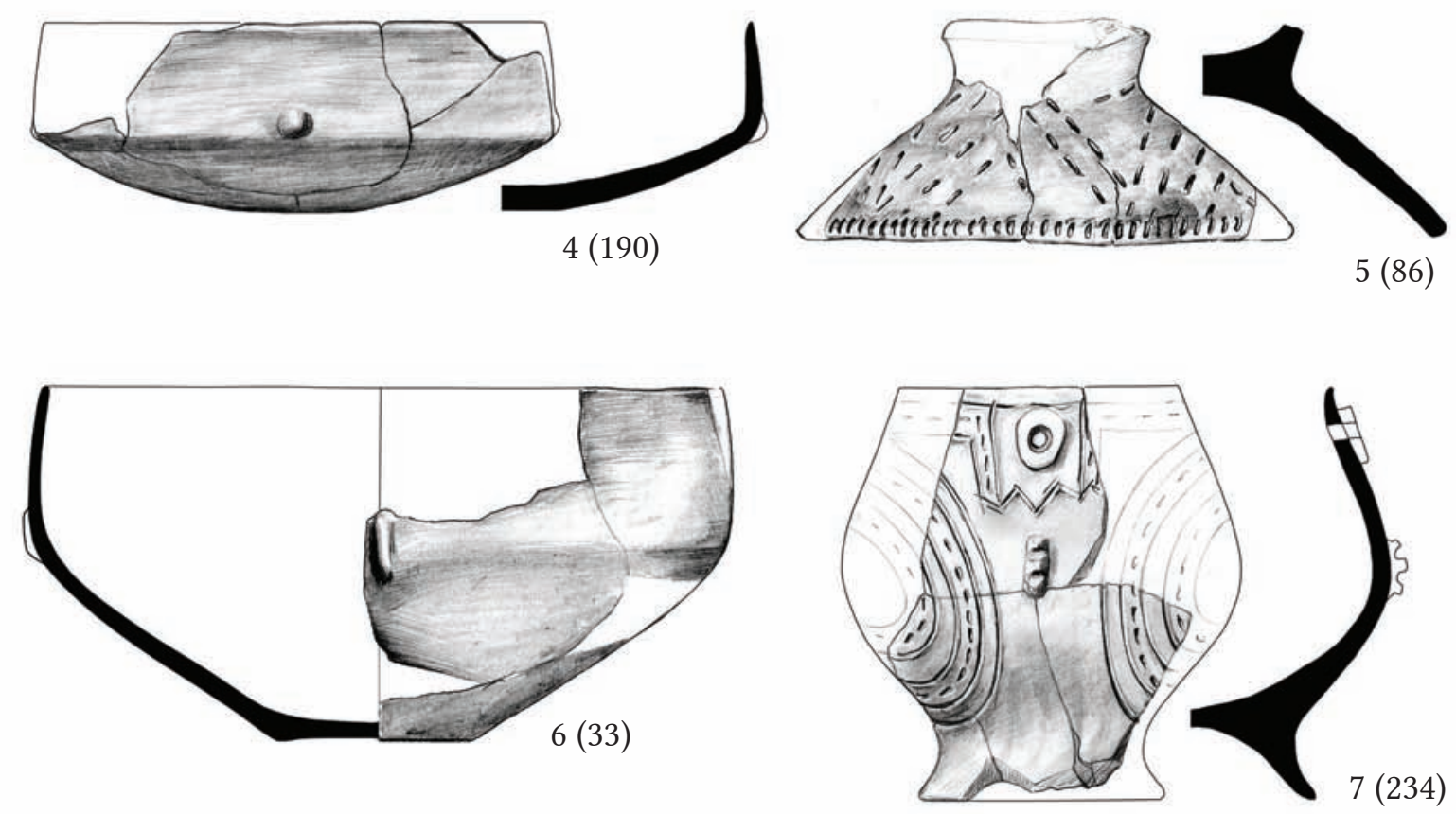

Fig. 45. Refitted vessels from the features dug into the prehistoric soil at Öcsöd-Kováshalom. 


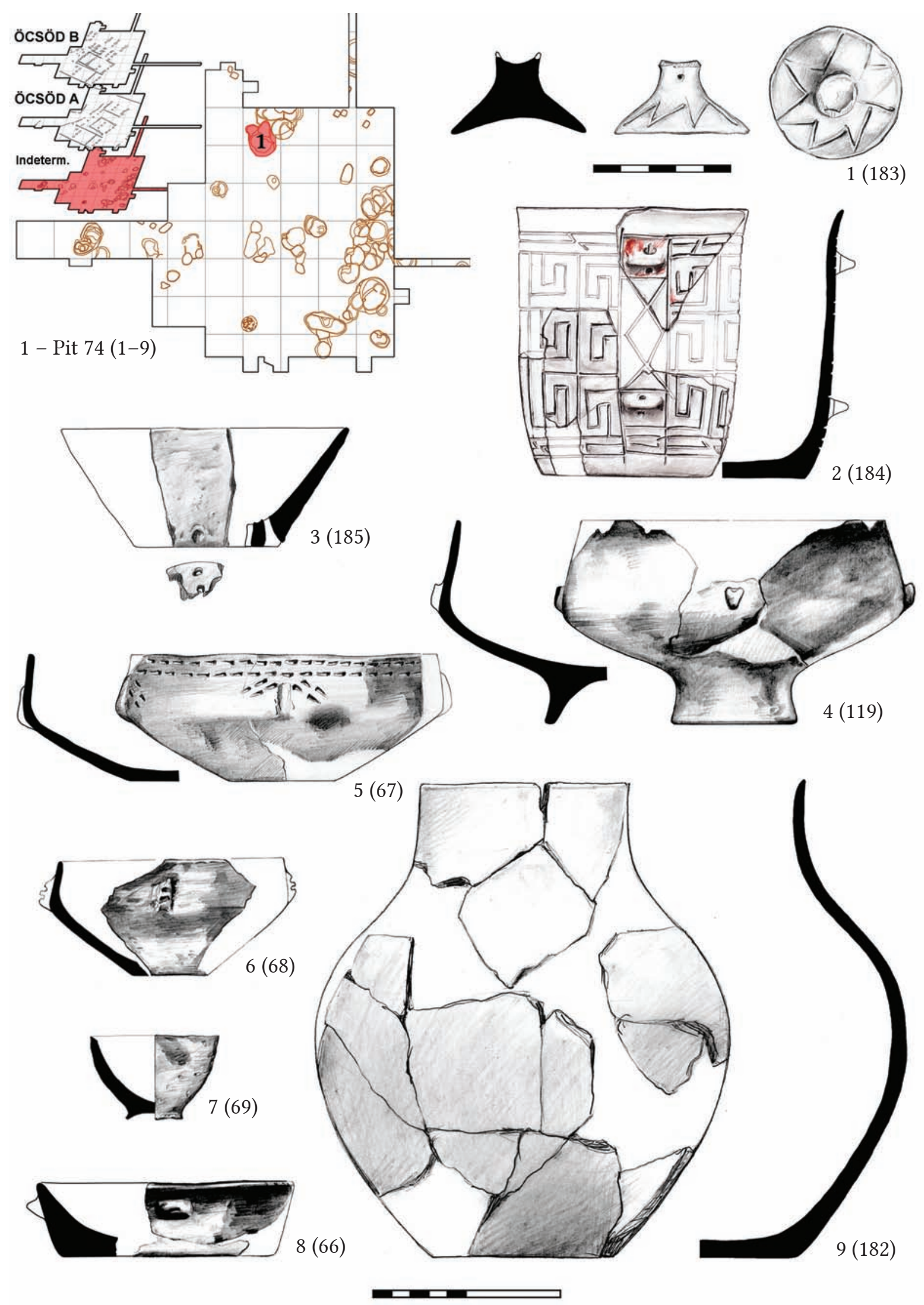

Fig. 46. Refitted vessels from the features dug into the prehistoric soil at Öcsöd-Kováshalom. 

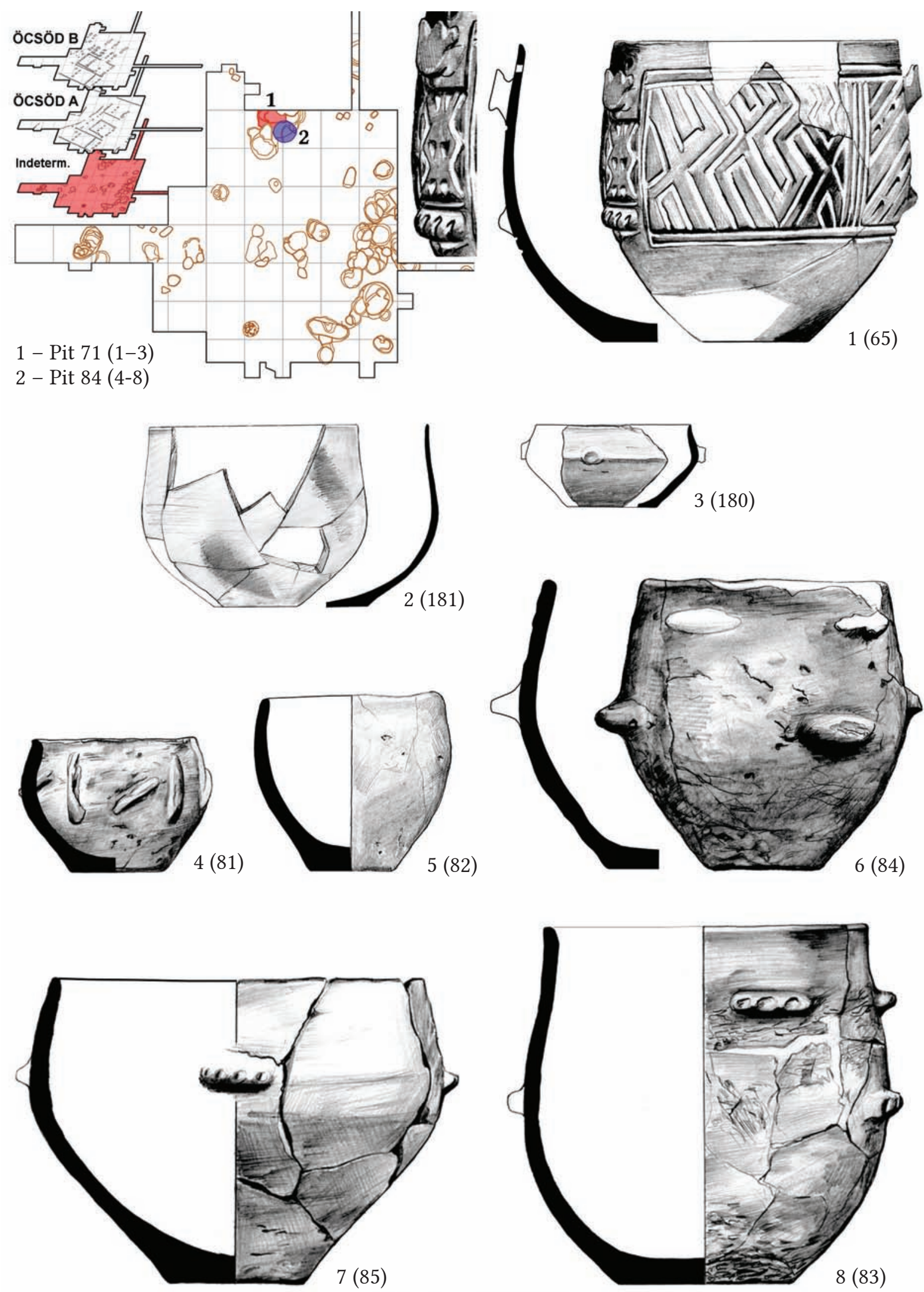

Fig. 47. Refitted vessels from the features dug into the prehistoric soil at Öcsöd-Kováshalom. 

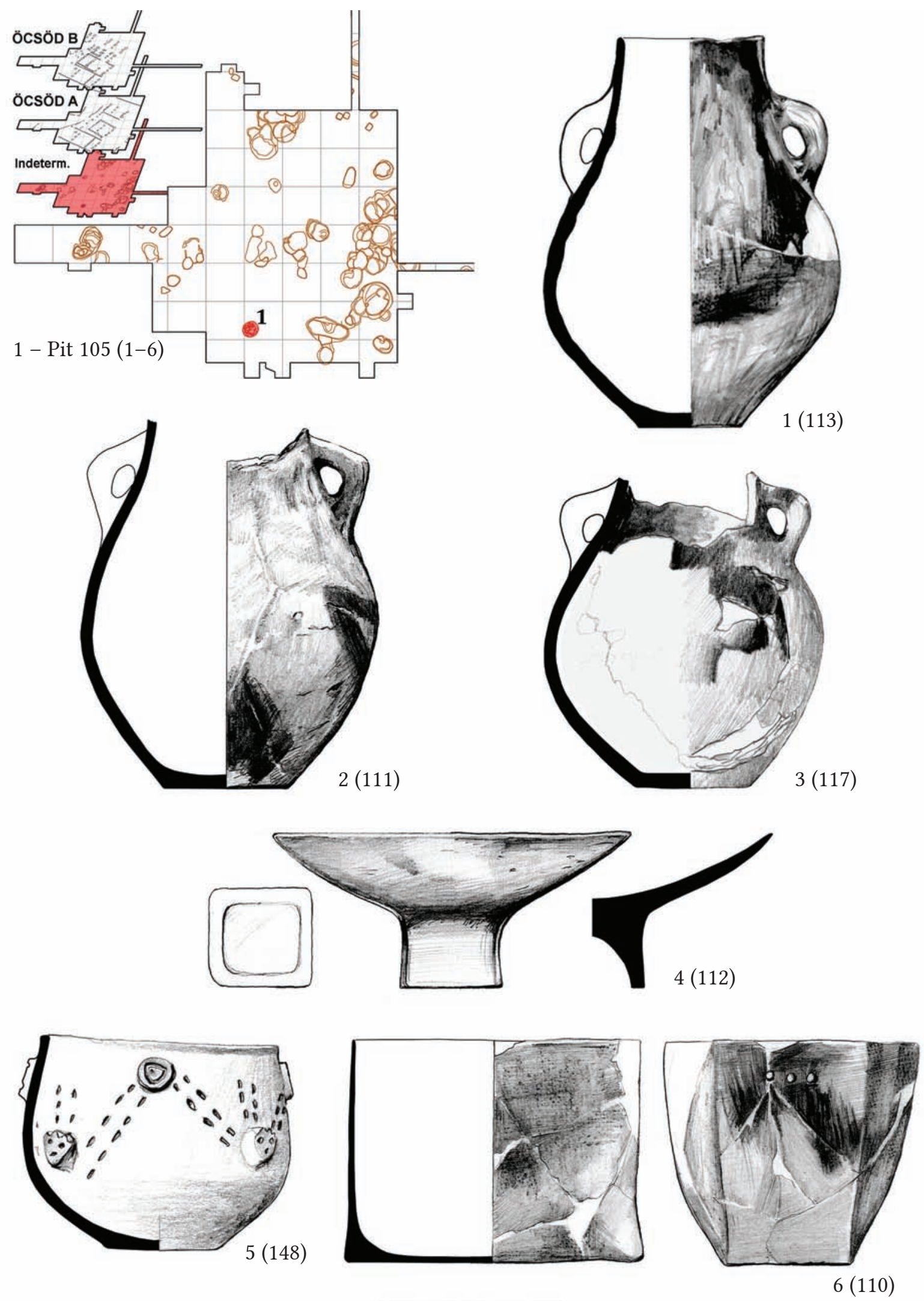

Fig. 48. Refitted vessels from the features dug into the prehistoric soil at Öcsöd-Kováshalom. 

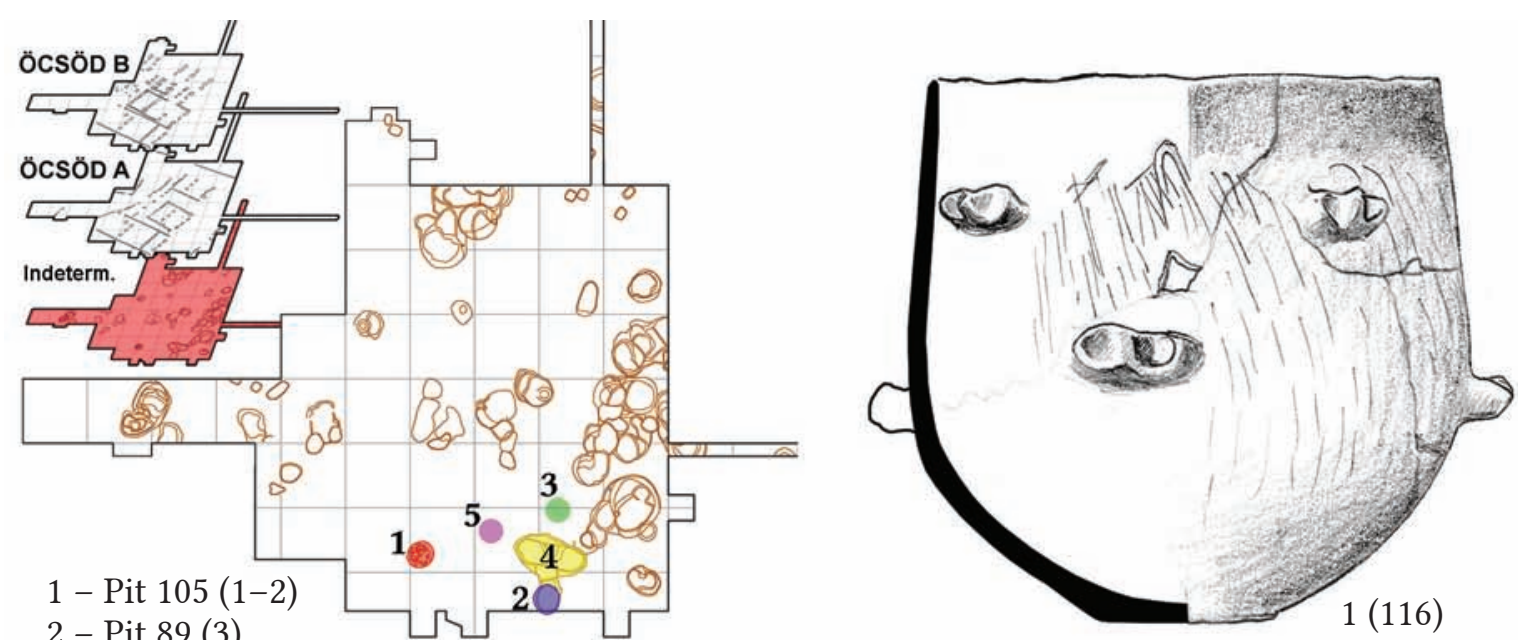

2 - Pit $89(3)$

3 - Pit $109(4,6)$

4 - Pit $37(5)$

5 - Pit $15(7)$
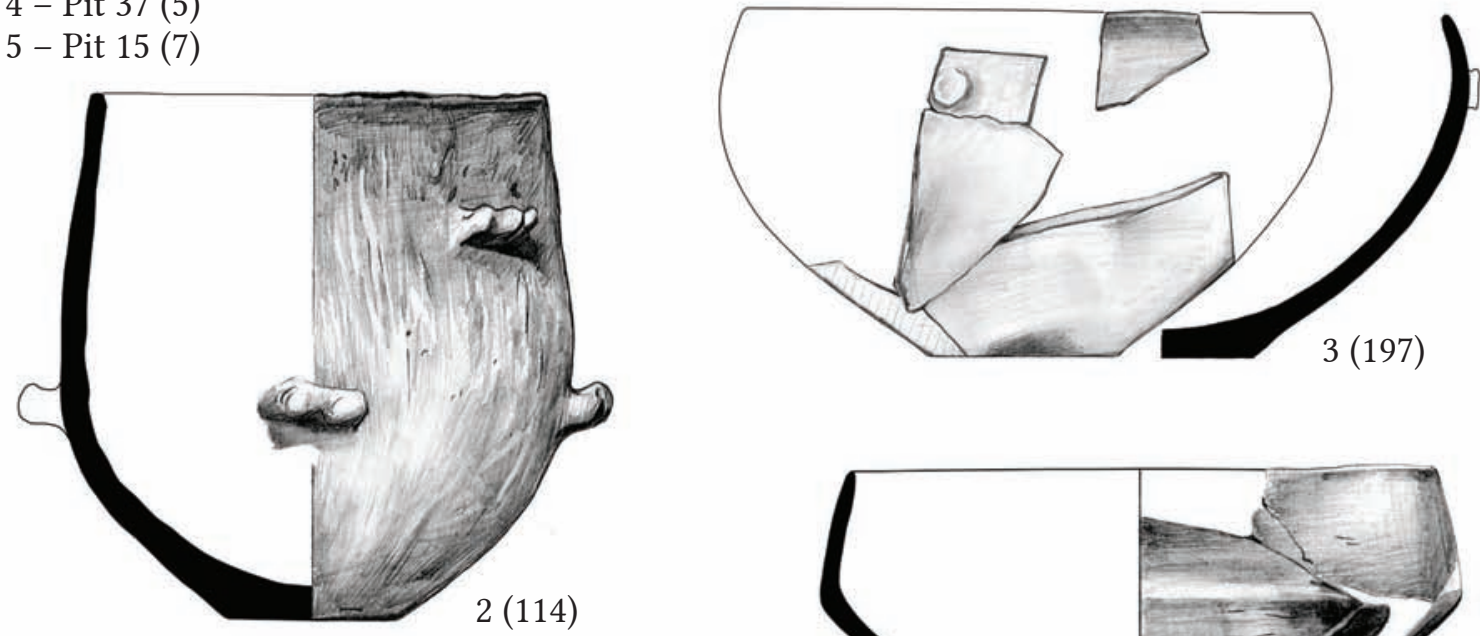

$2(114)$
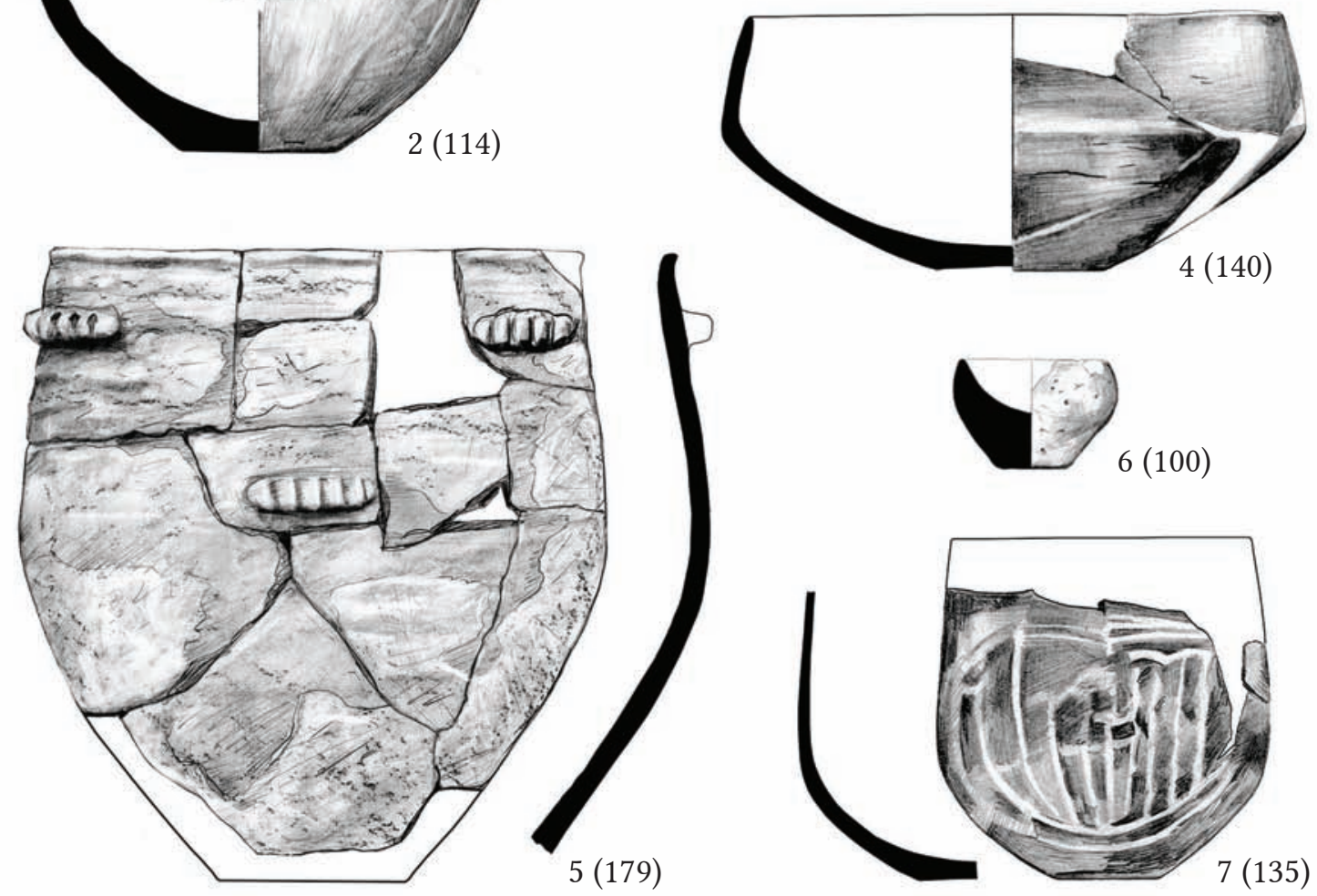

(135)

Fig. 49. Refitted vessels from the features dug into the prehistoric soil at Öcsöd-Kováshalom. 

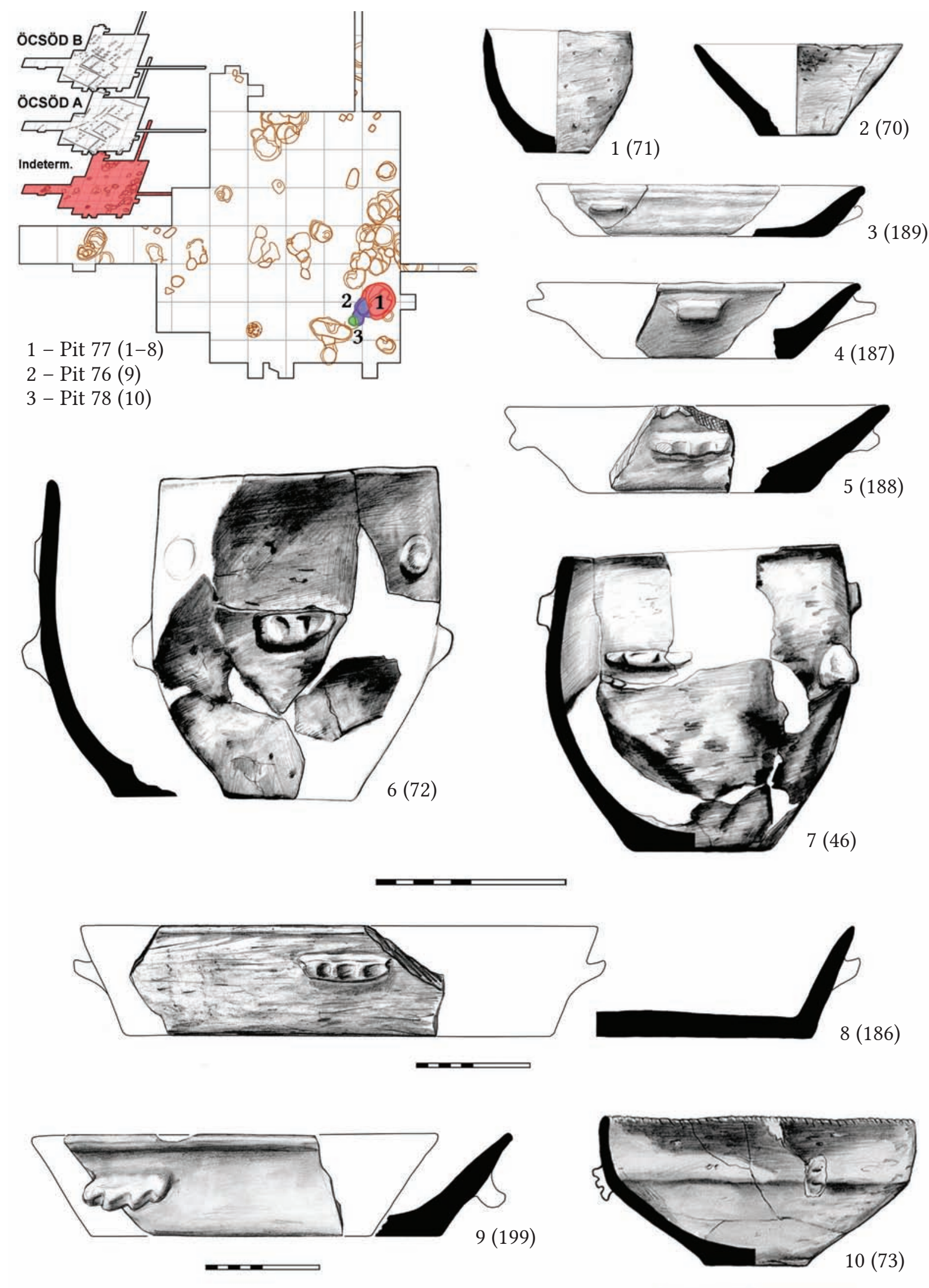

Fig. 50. Refitted vessels from the features dug into the prehistoric soil at Öcsöd-Kováshalom. 

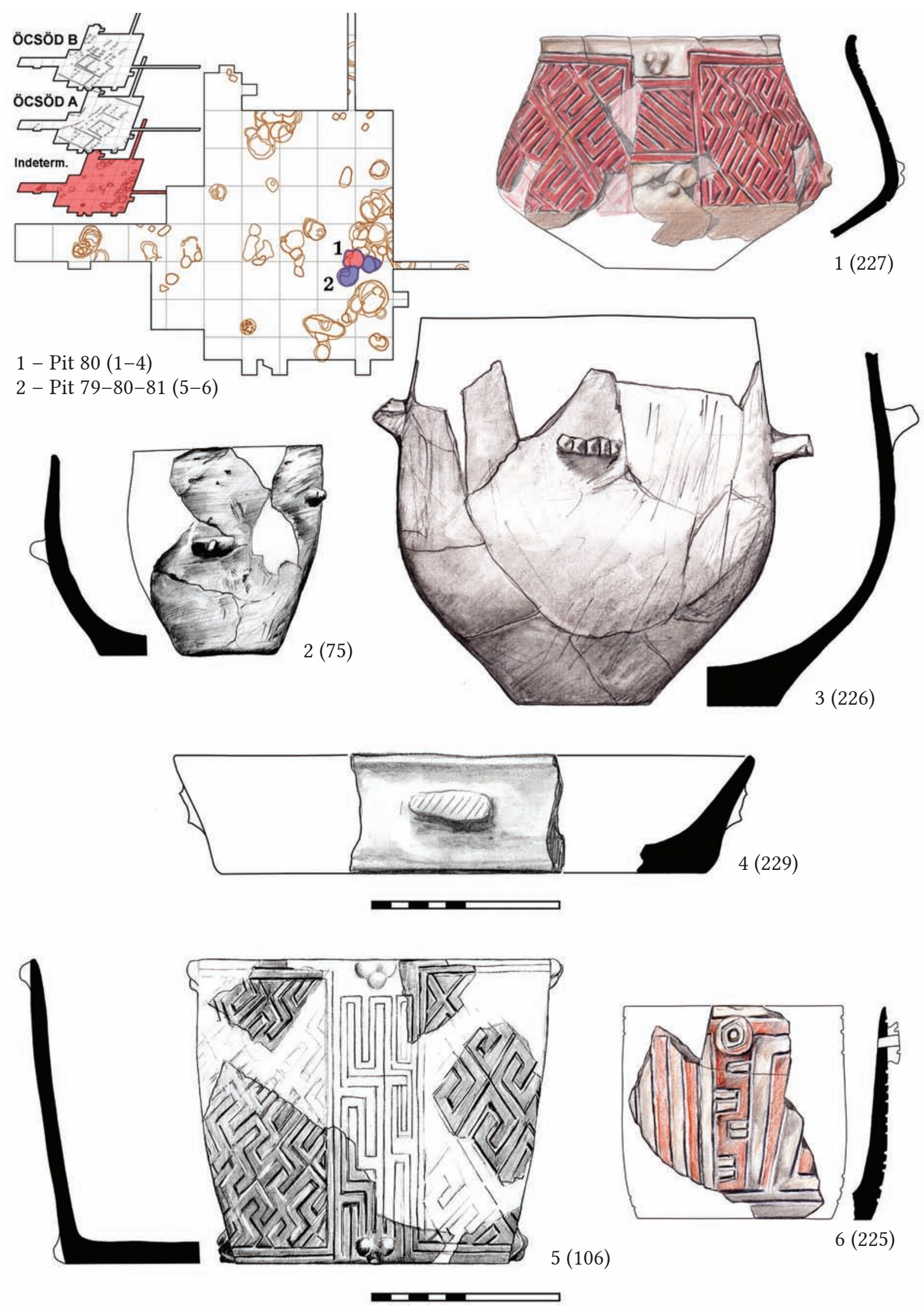

Fig. 51. Refitted vessels from the features dug into the prehistoric soil at Öcsöd-Kováshalom. 


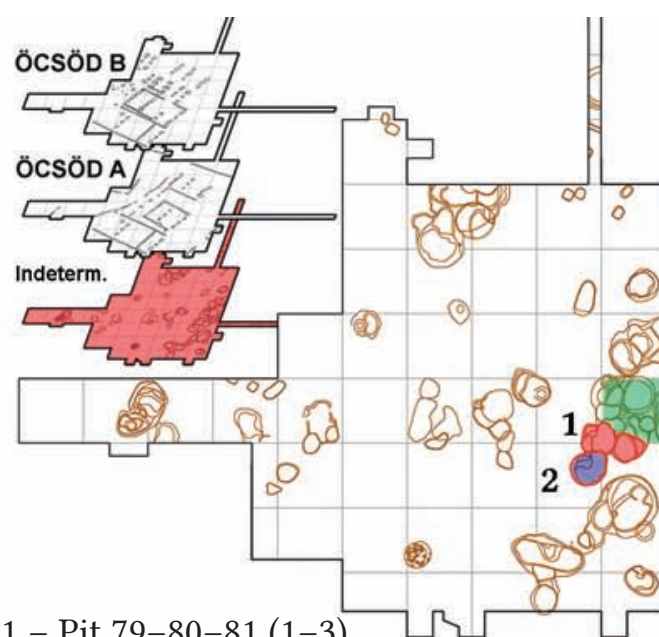

$1(1-3)$

2 - Pit $81(4-6)$

3 - Area 3 (7-8)

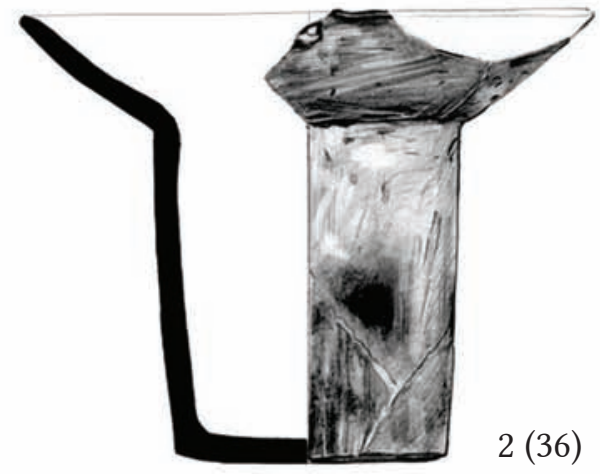

3
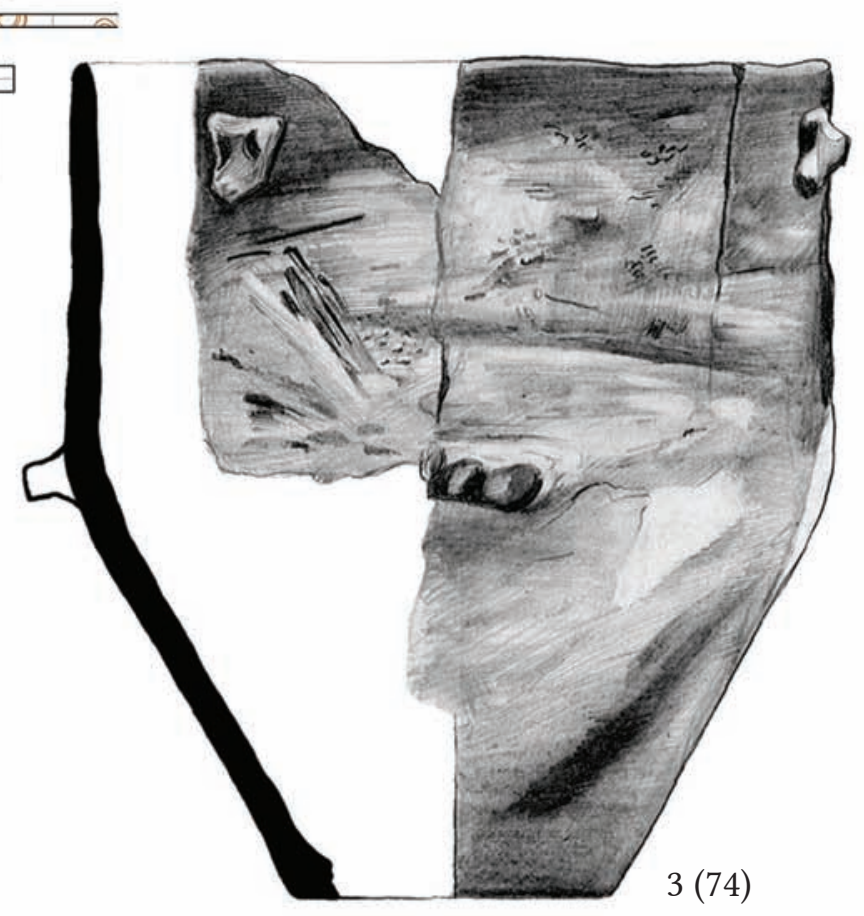

$1(105)$

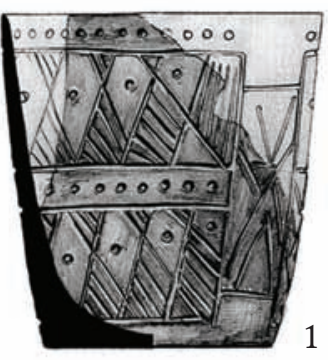

$4(78)$
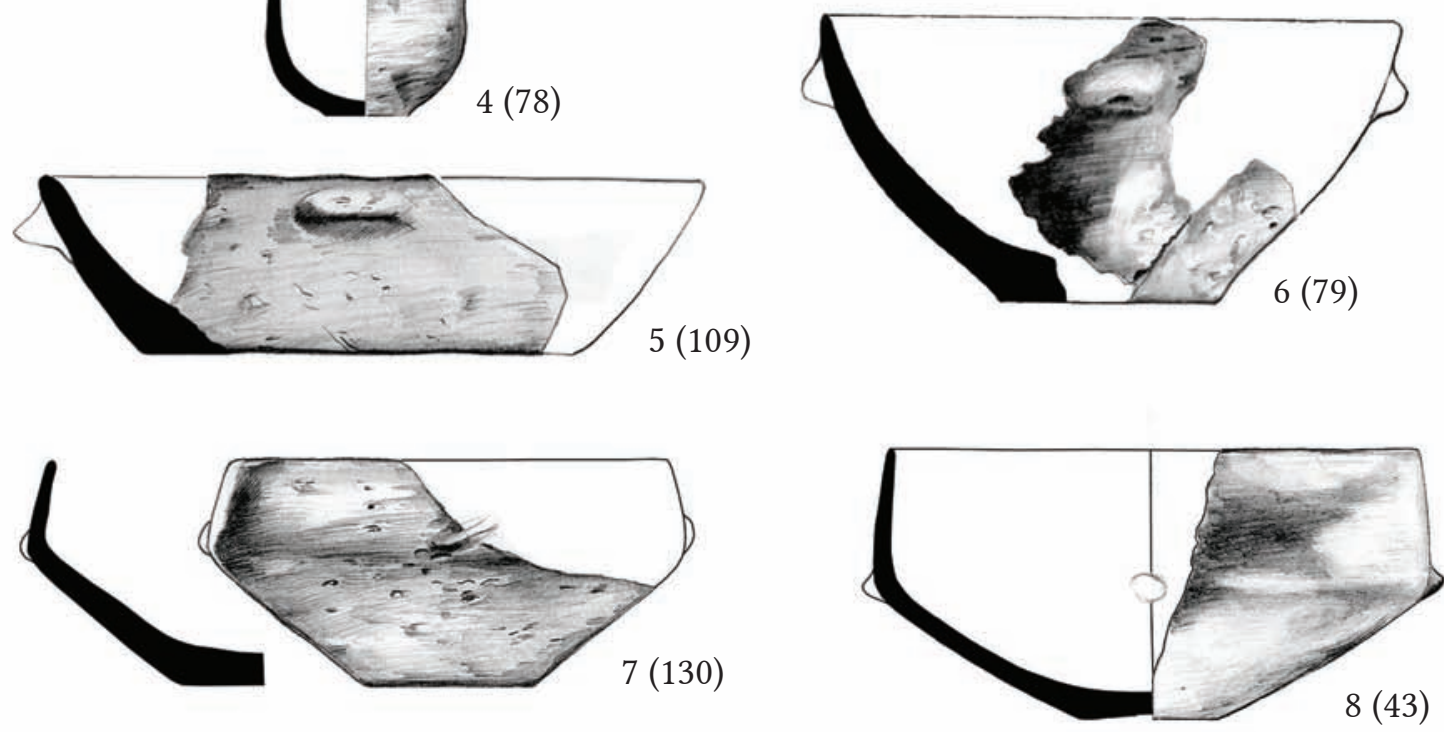

Fig. 52. Refitted vessels from the features dug into the prehistoric soil at Öcsöd-Kováshalom. 

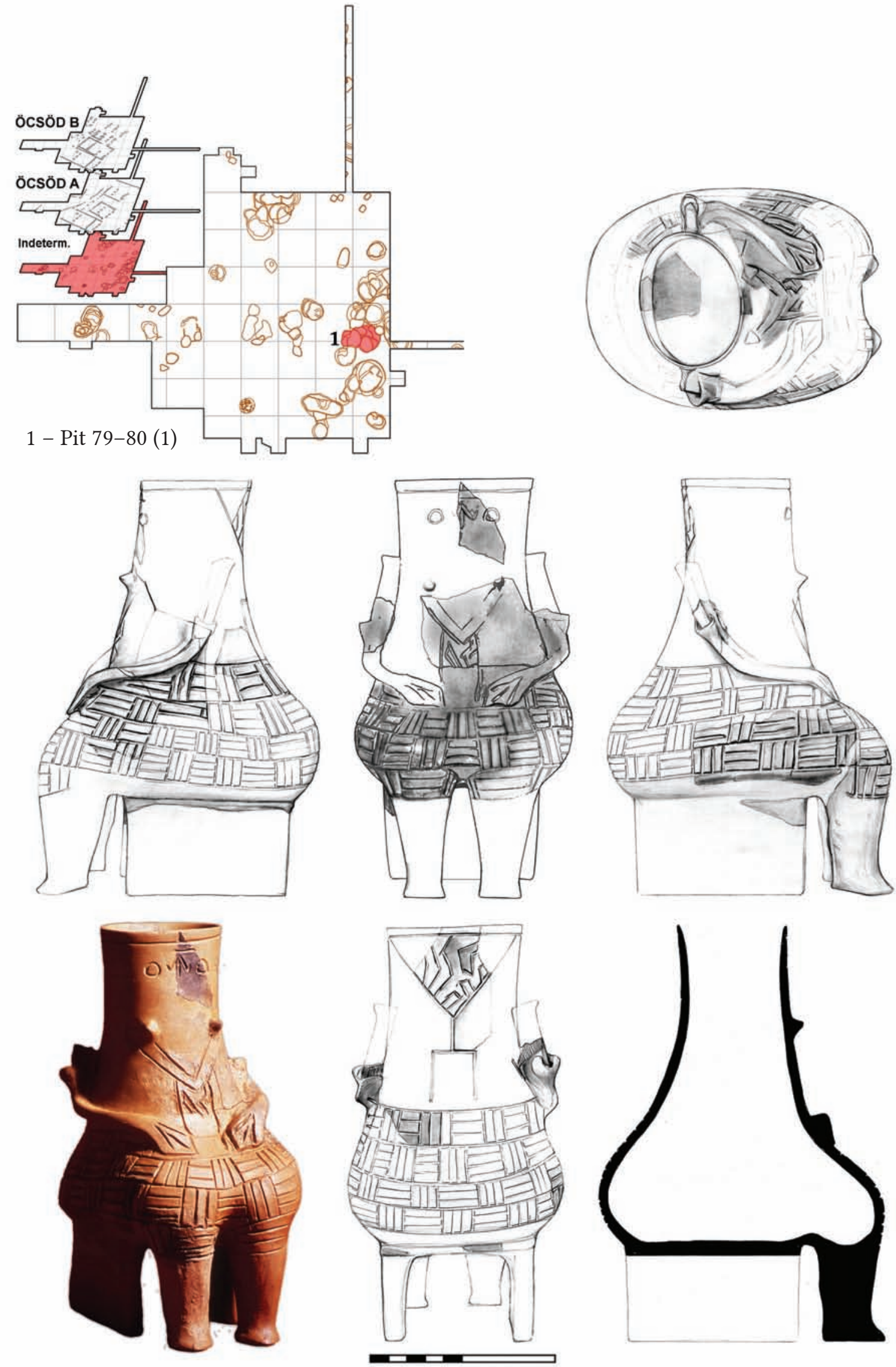

Fig. 53. Refitted vessels from the features dug into the prehistoric soil at Öcsöd-Kováshalom. 

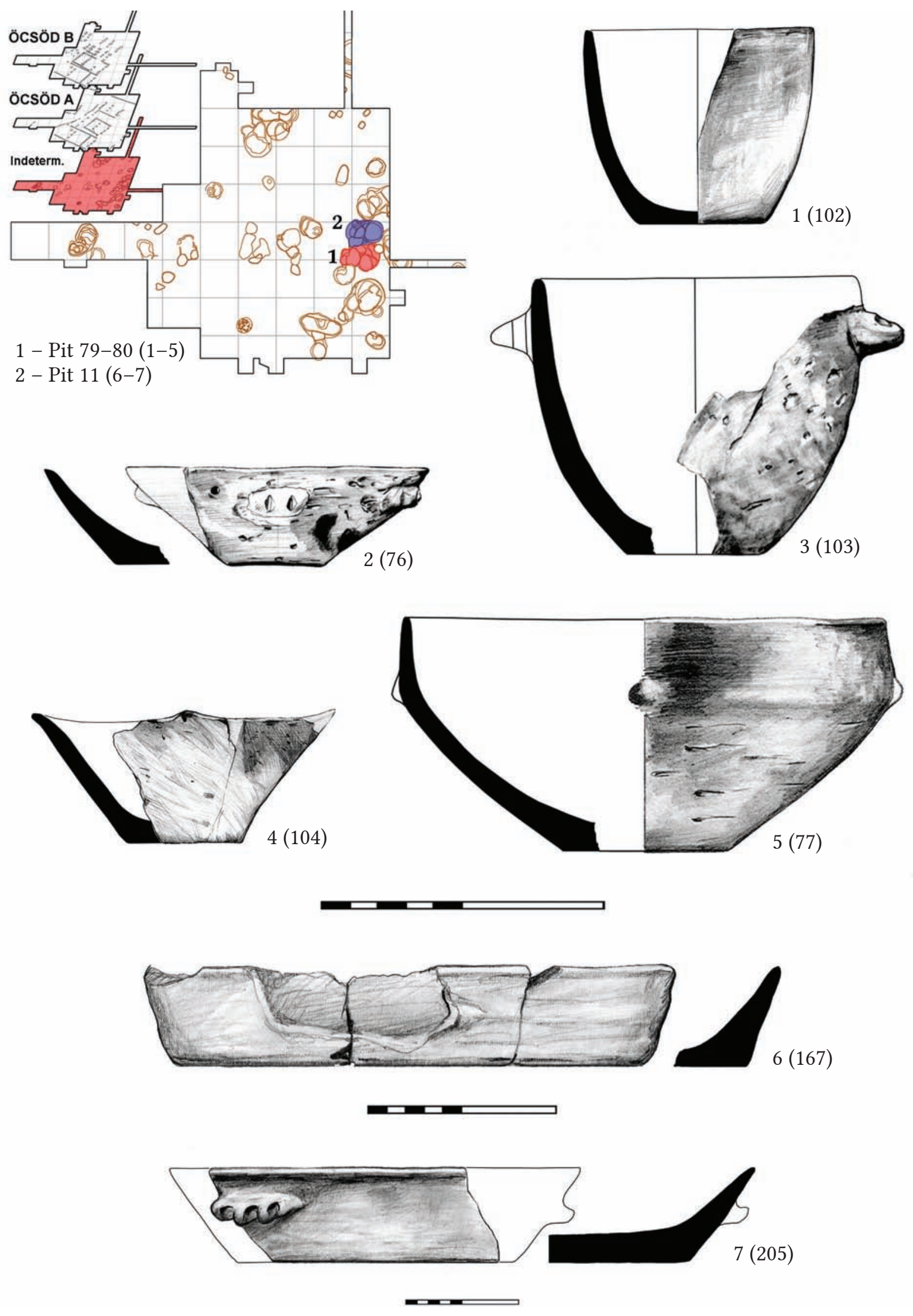

Fig. 54. Refitted vessels from the features dug into the prehistoric soil at Öcsöd-Kováshalom. 

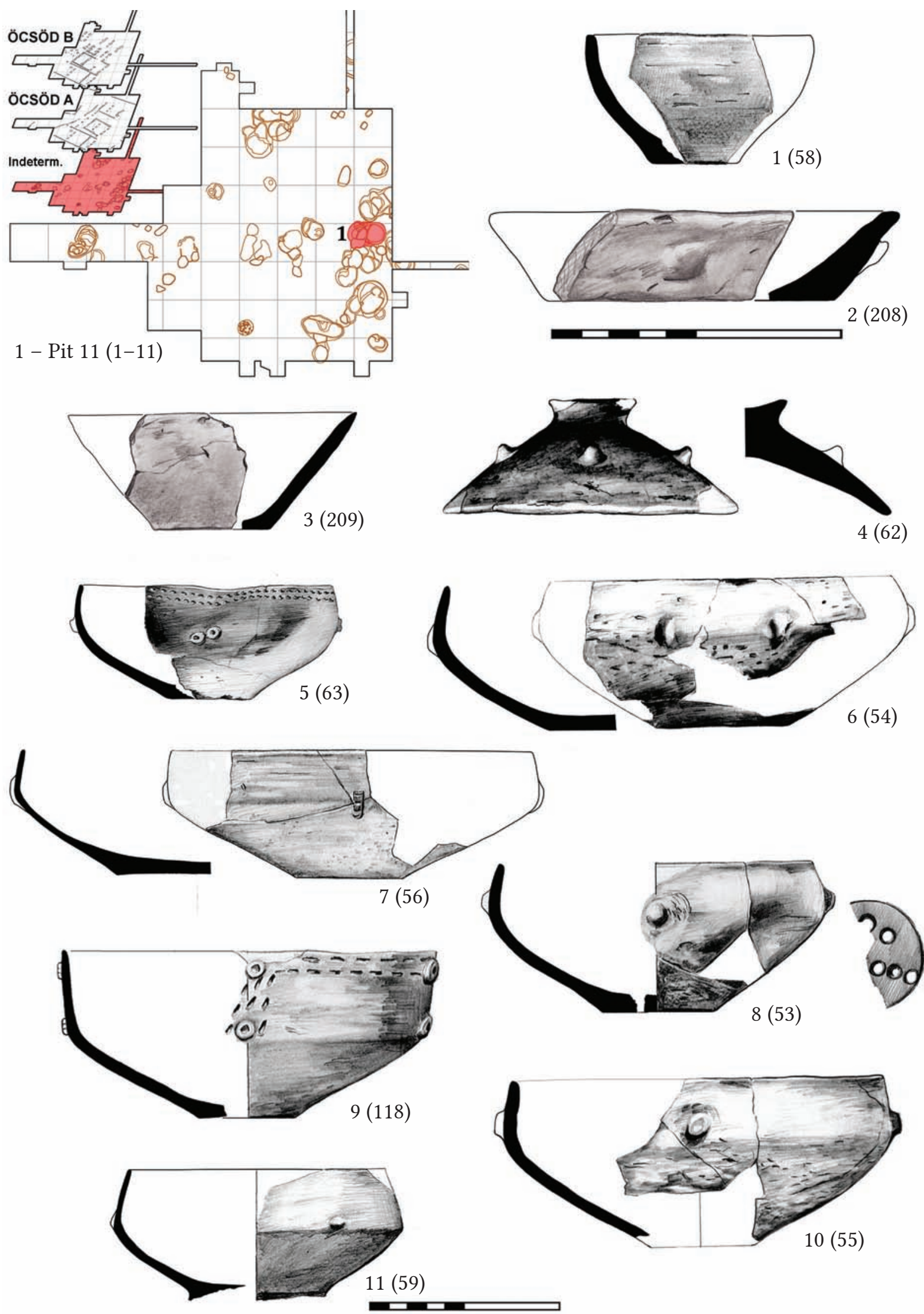

Fig. 55. Refitted vessels from the features dug into the prehistoric soil at Öcsöd-Kováshalom. 

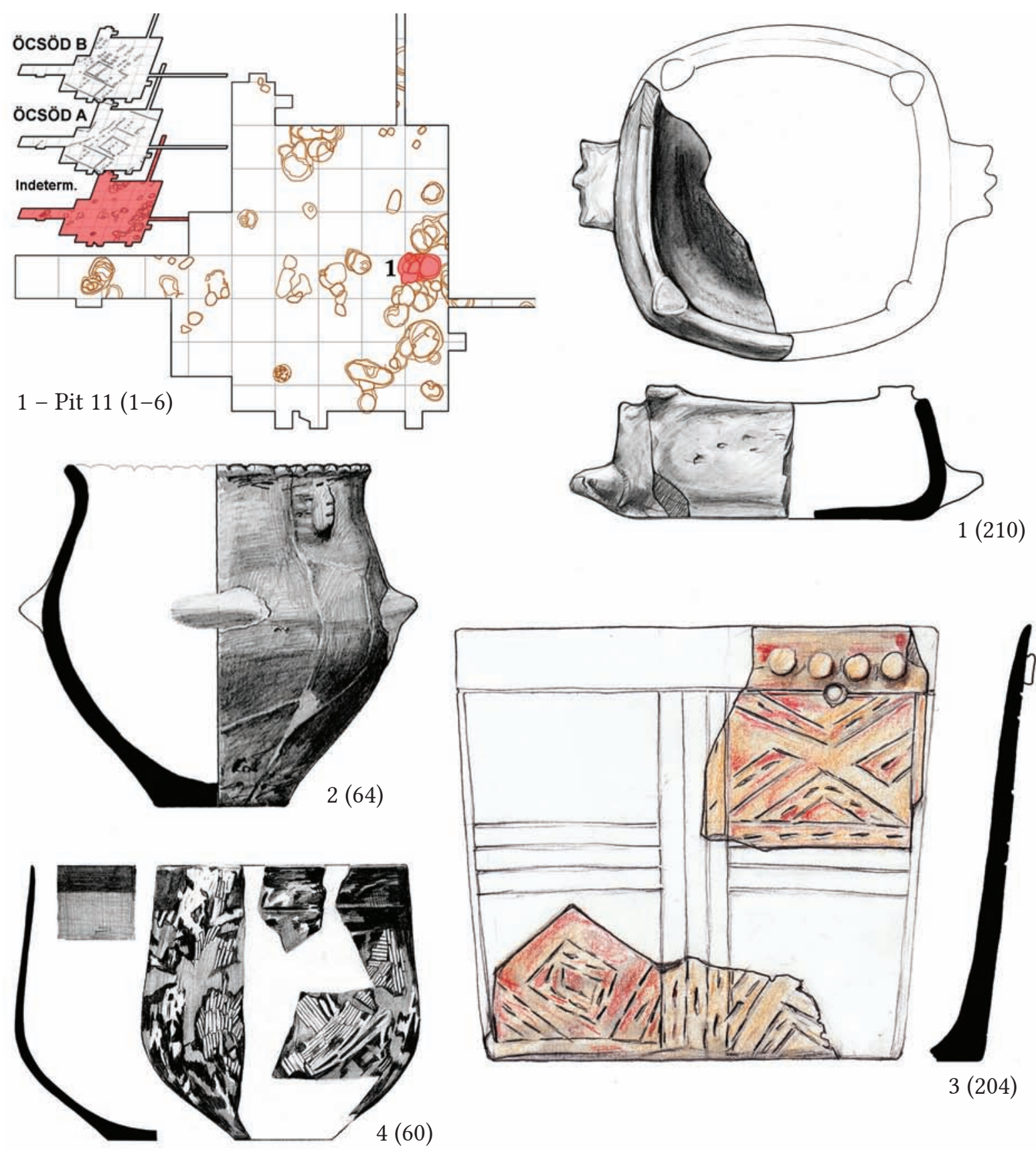

$3(204)$

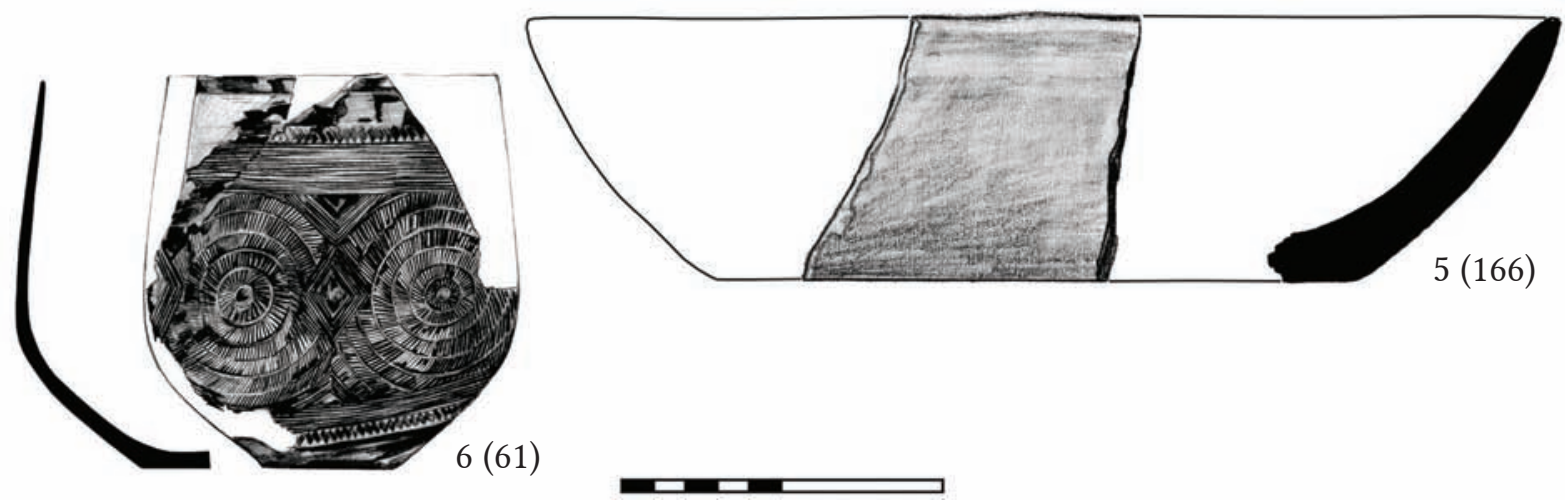

Fig. 56. Refitted vessels from the features dug into the prehistoric soil at Öcsöd-Kováshalom. 

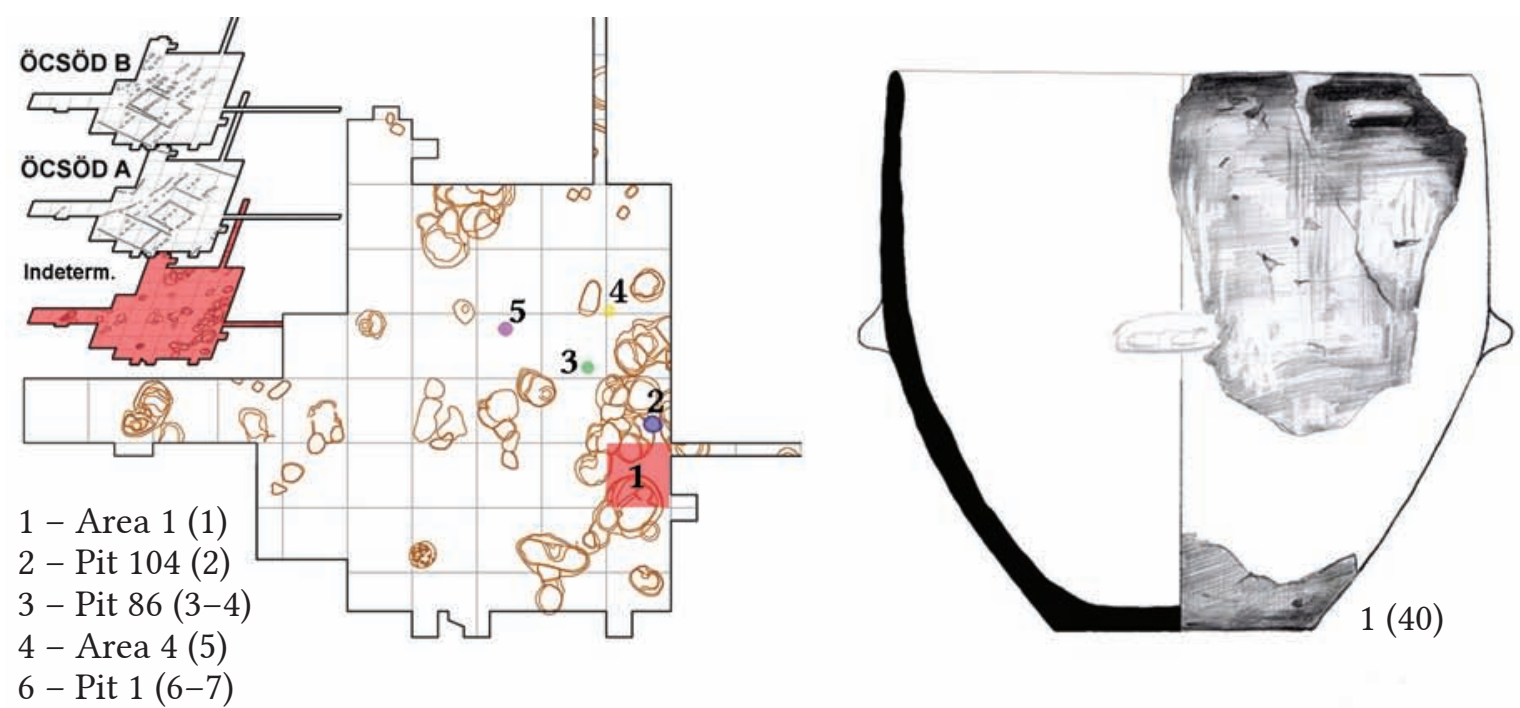

6 - Pit $1(6-7)$
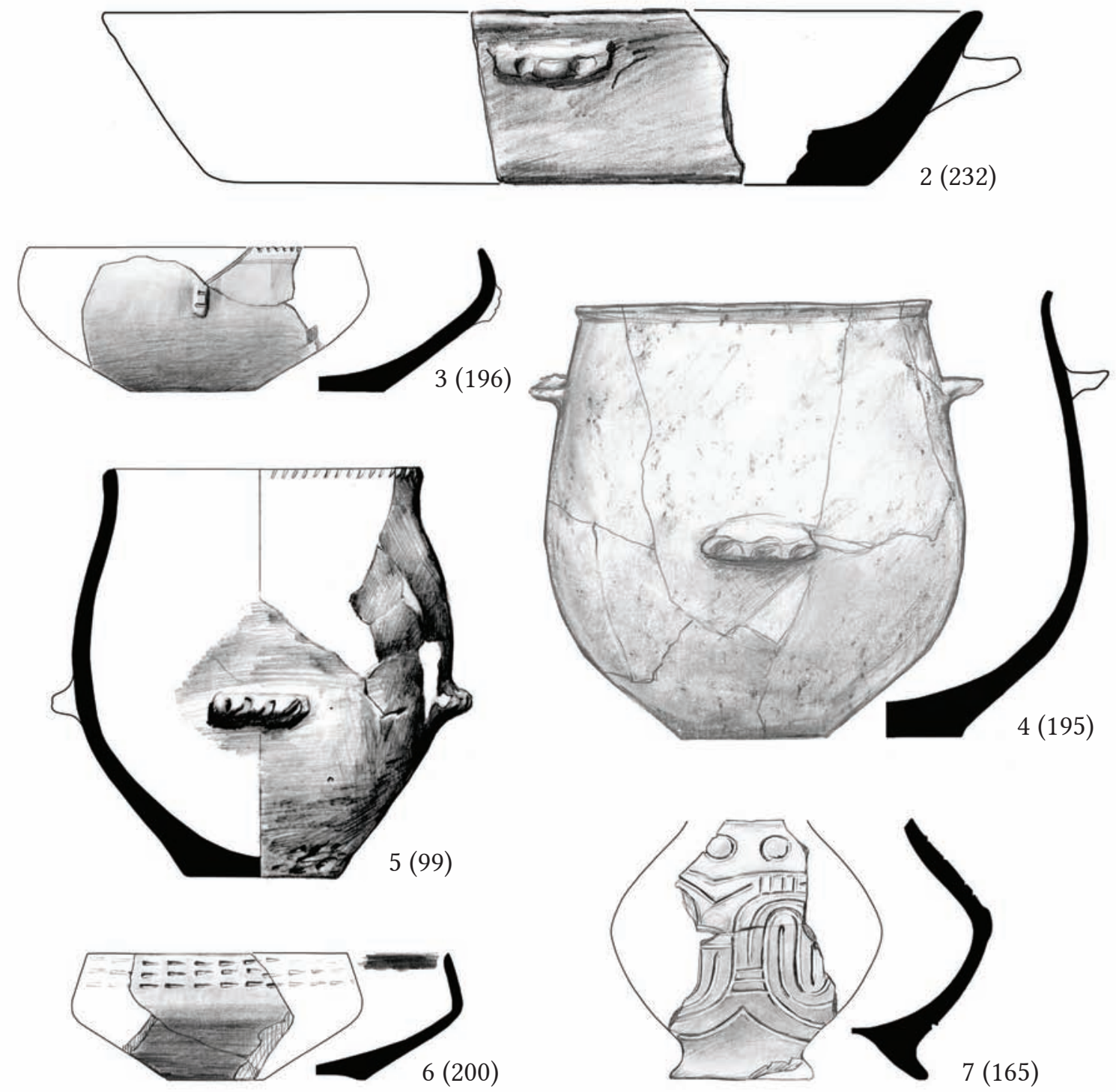

Fig. 57. Refitted vessels from the features dug into the prehistoric soil at Öcsöd-Kováshalom. 

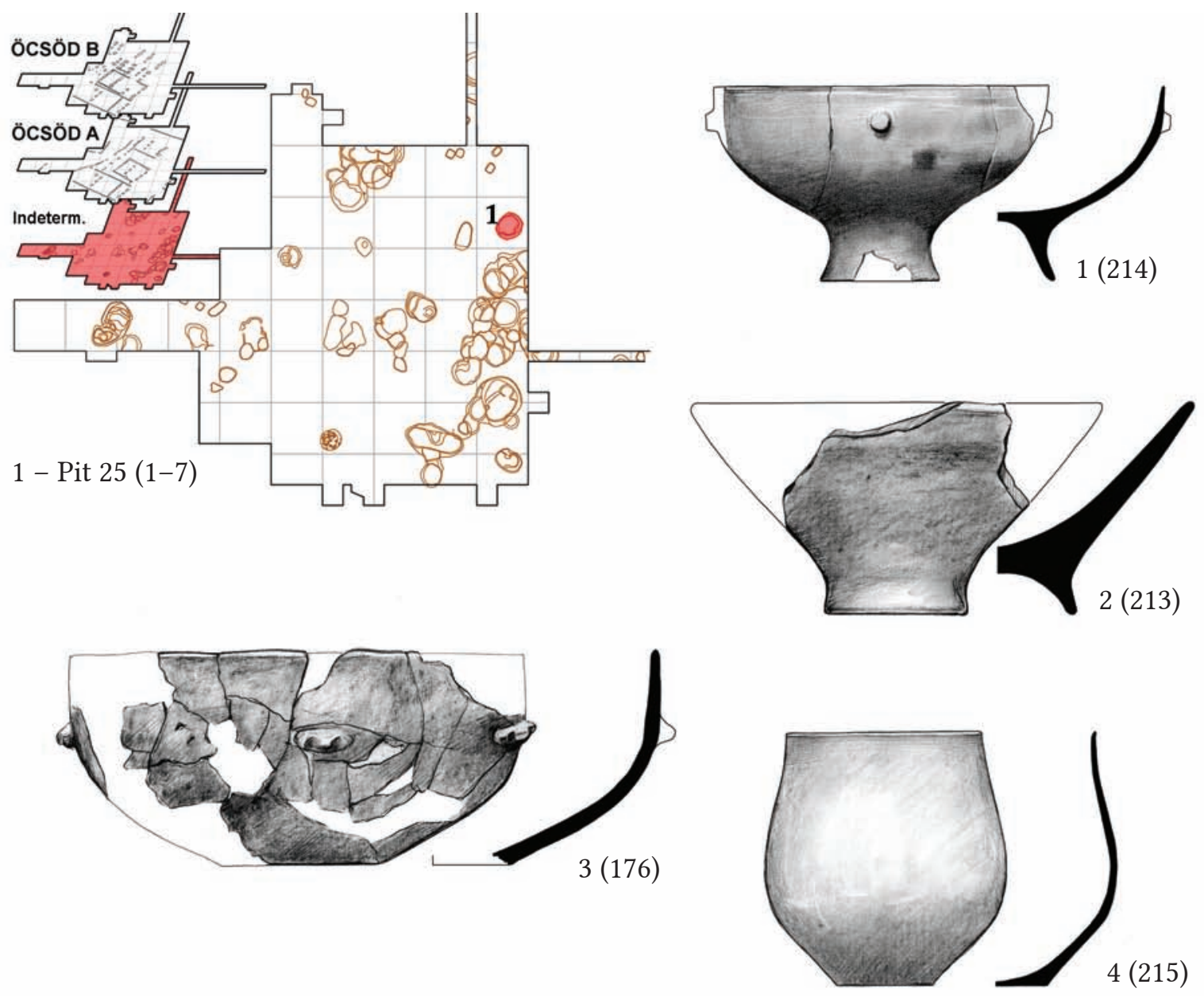

$4(215)$
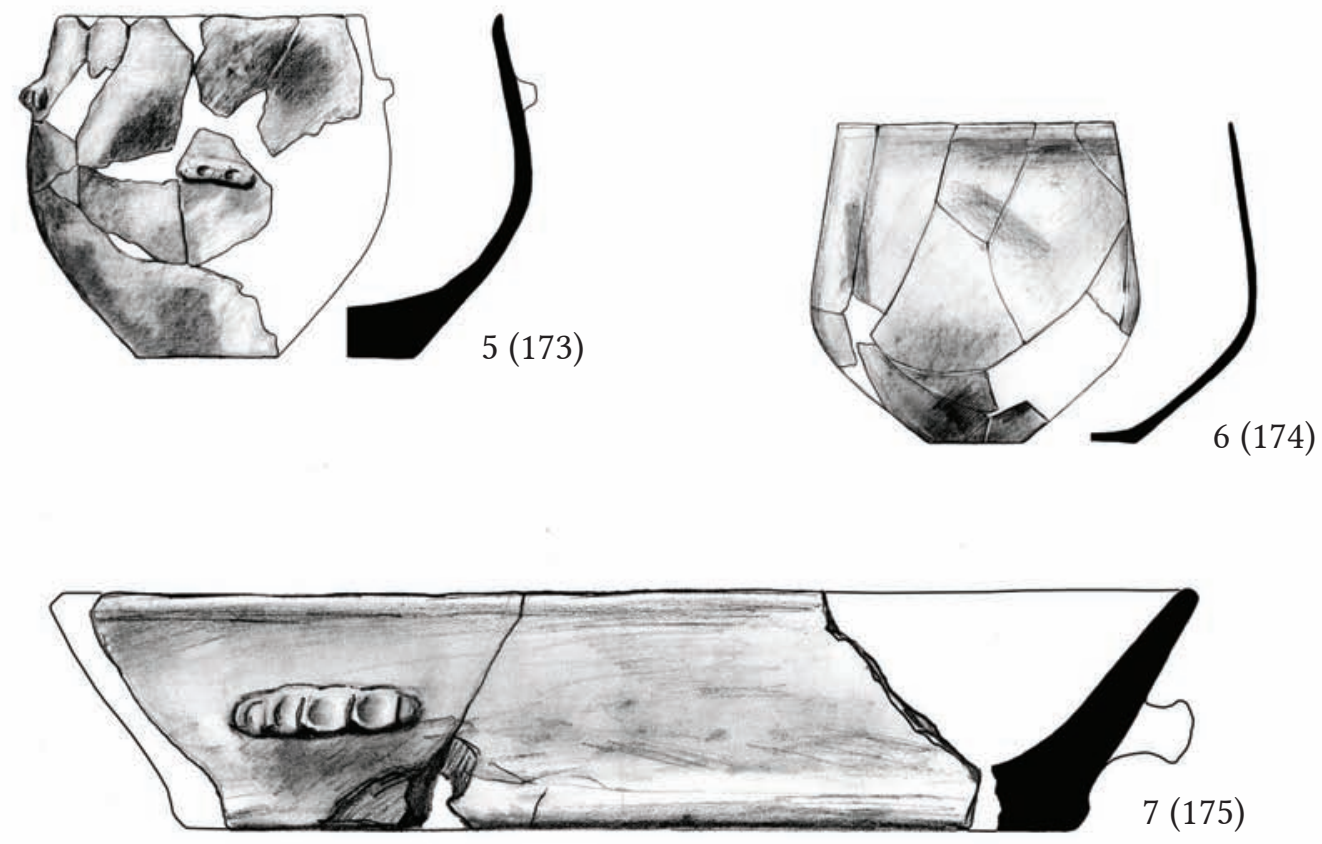

Fig. 58. Refitted vessels from the features dug into the prehistoric soil at Öcsöd-Kováshalom. 

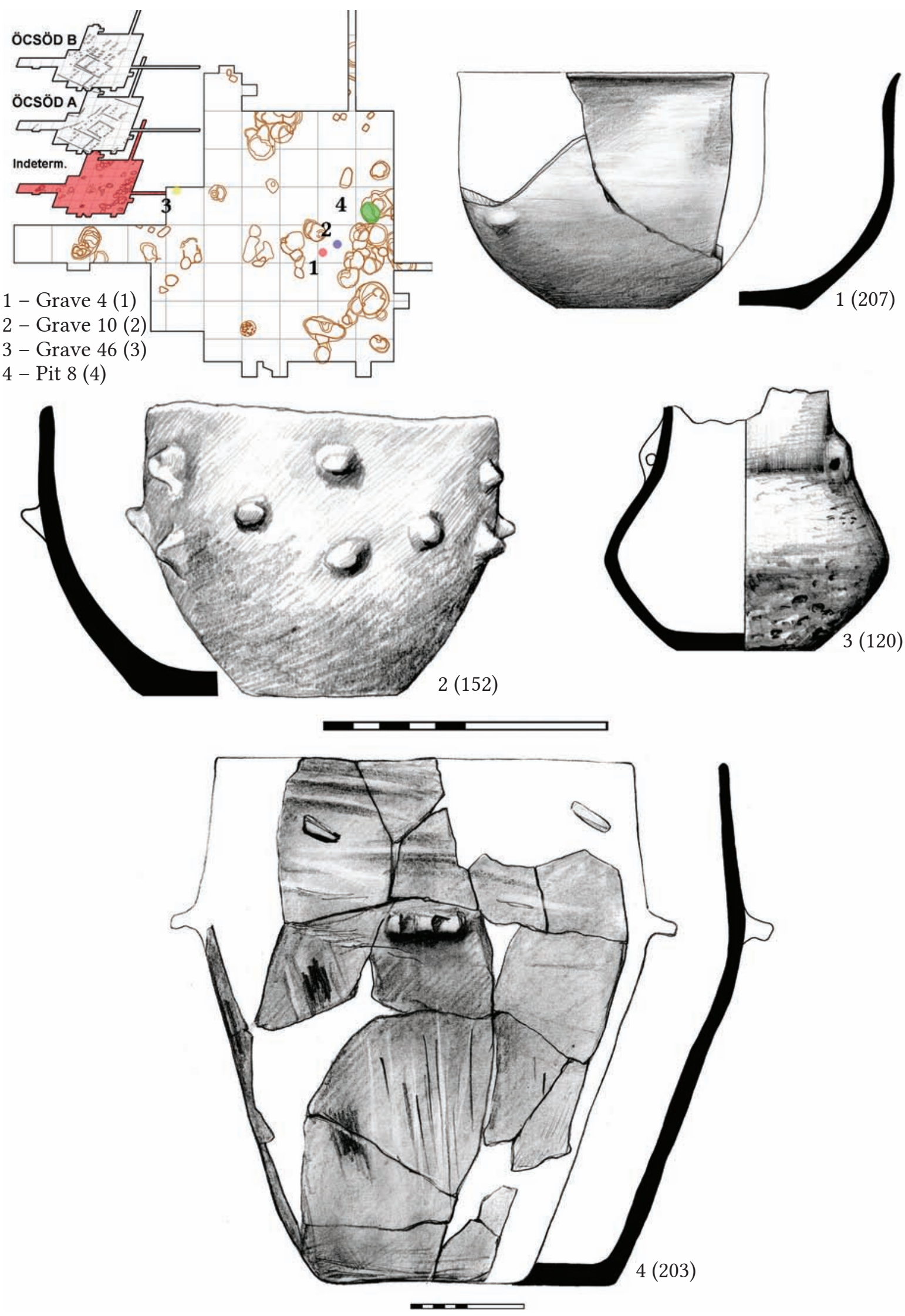

Fig. 59. Refitted vessels from the features dug into the prehistoric soil at Öcsöd-Kováshalom. 

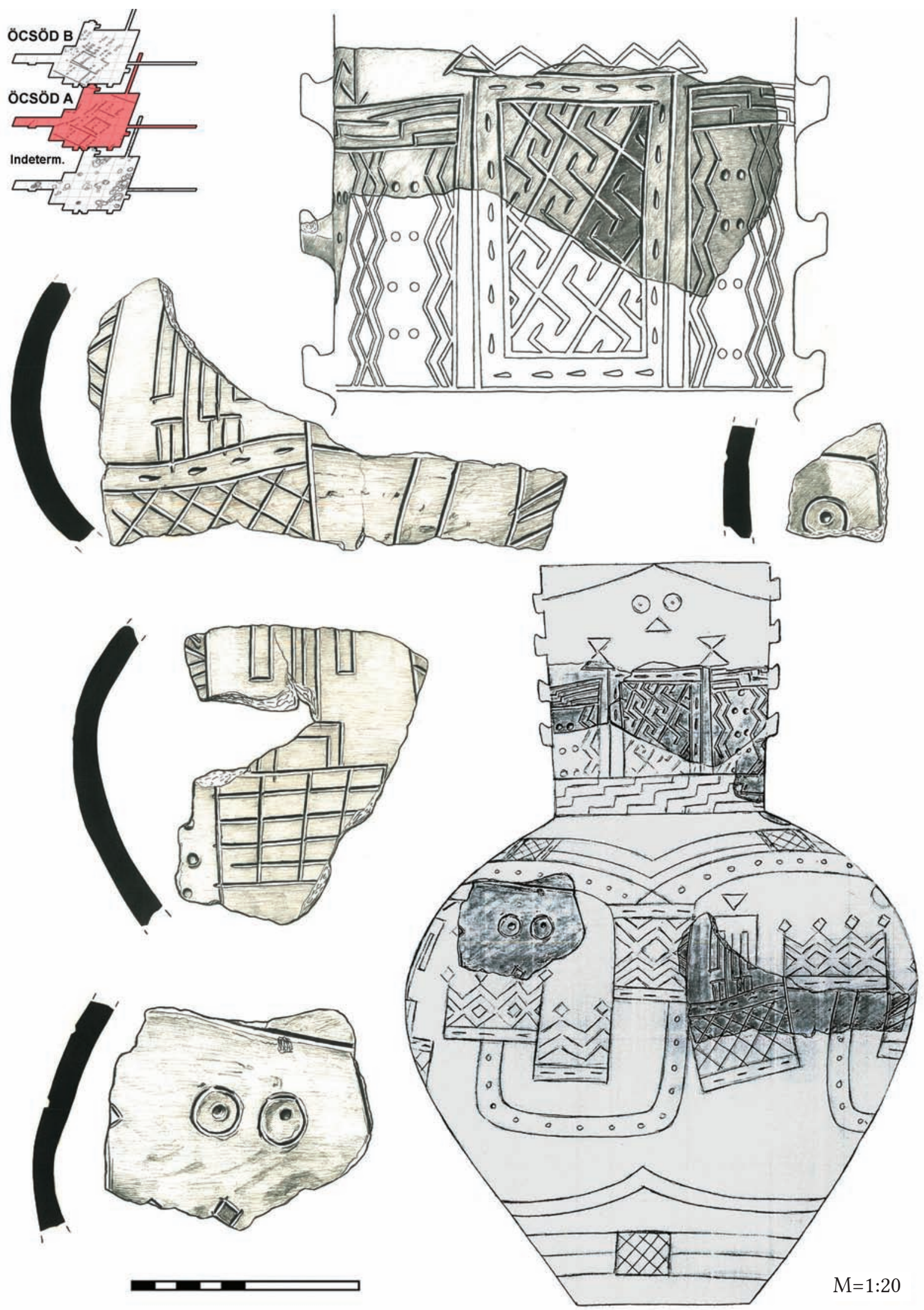

Fig. 60. Refitted vessels from uncertain contexts at Öcsöd-Kováshalom. 

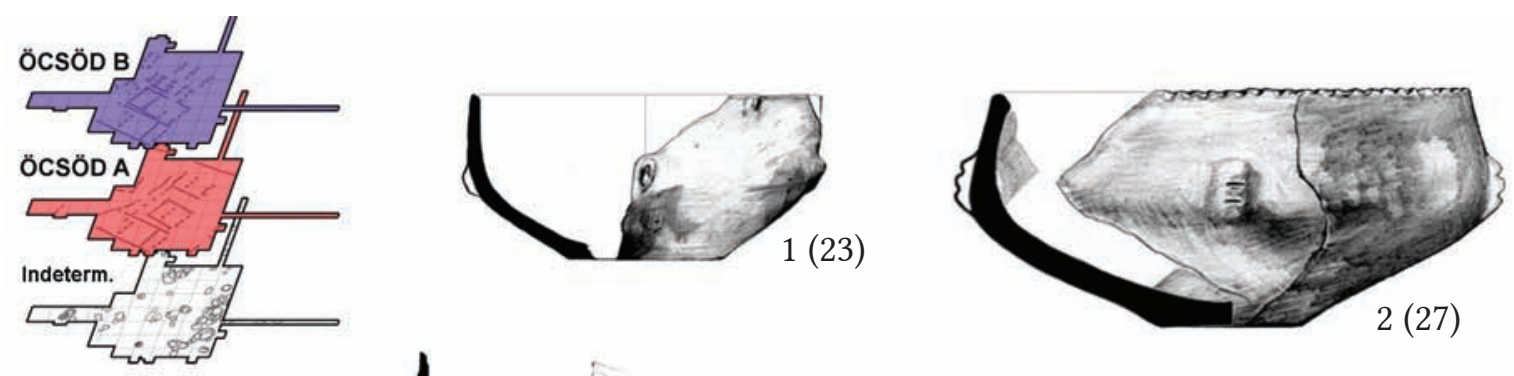

Öcsöd A (1-4)

Öcsöd B (5-6)
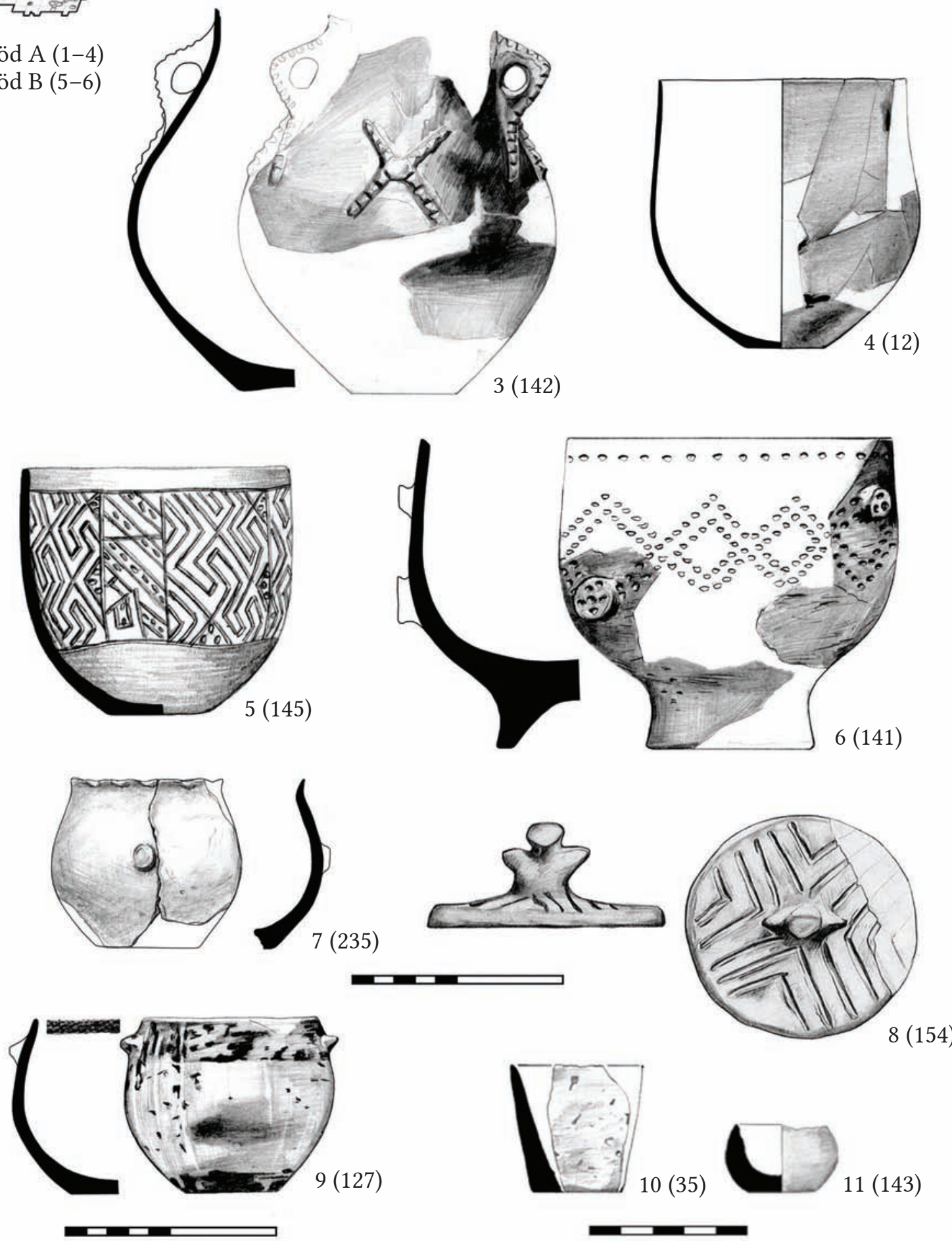

$11(143)$

Fig. 61. Refitted vessels from uncertain contexts at Öcsöd-Kováshalom. 


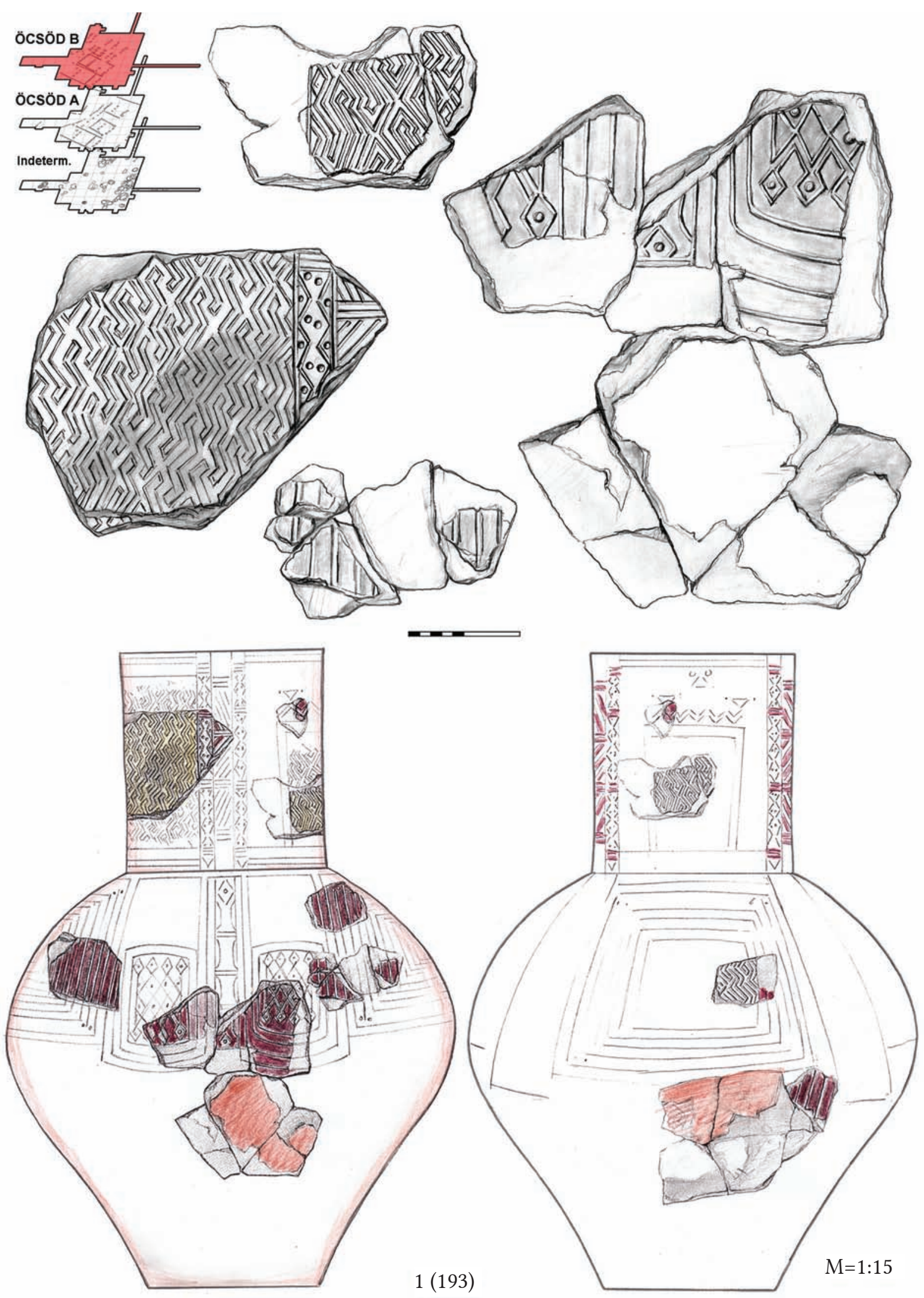

Fig. 62. Refitted vessels from uncertain contexts at Öcsöd-Kováshalom. 

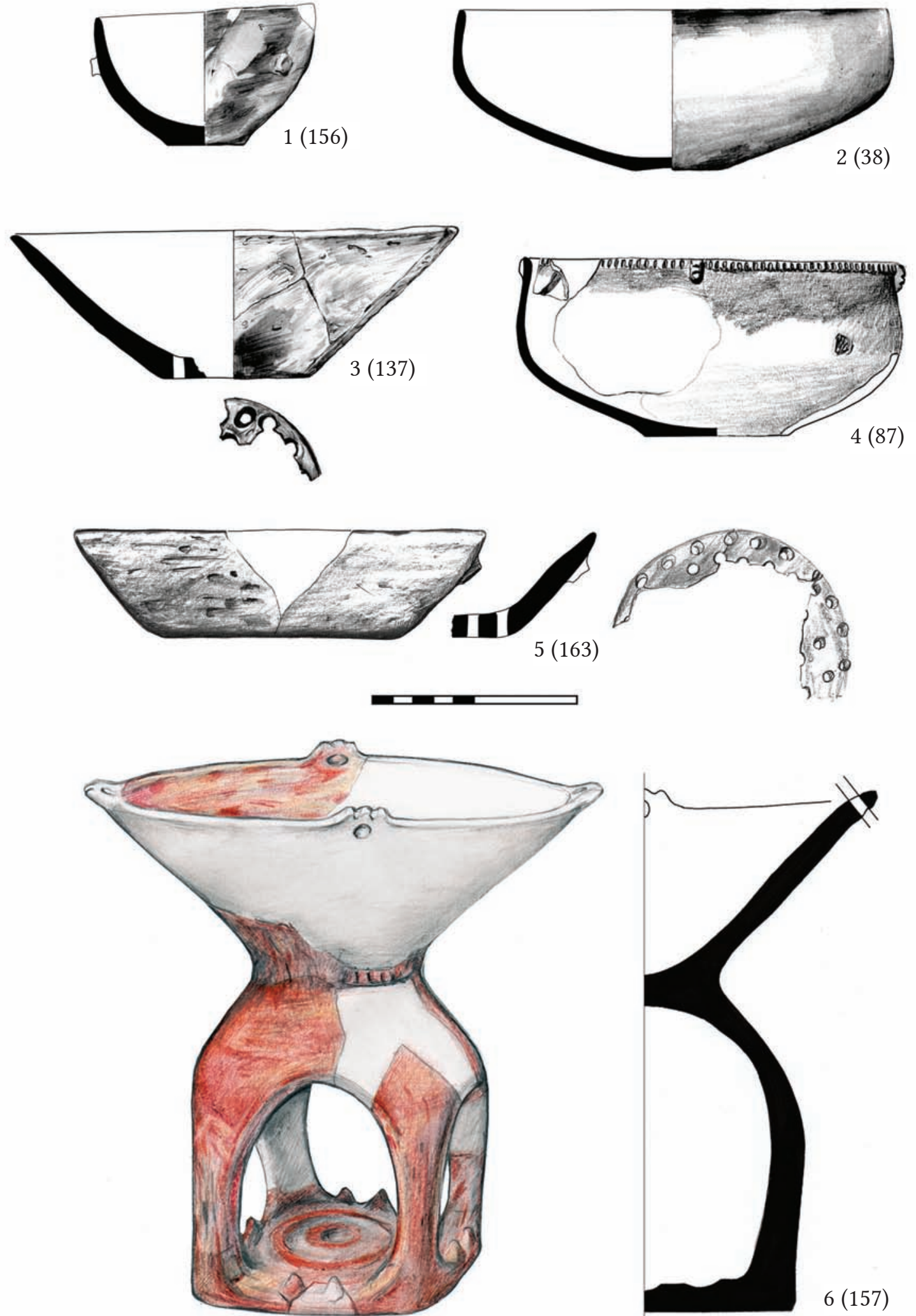

Fig. 63. Refitted vessels from uncertain contexts at Öcsöd-Kováshalom. 

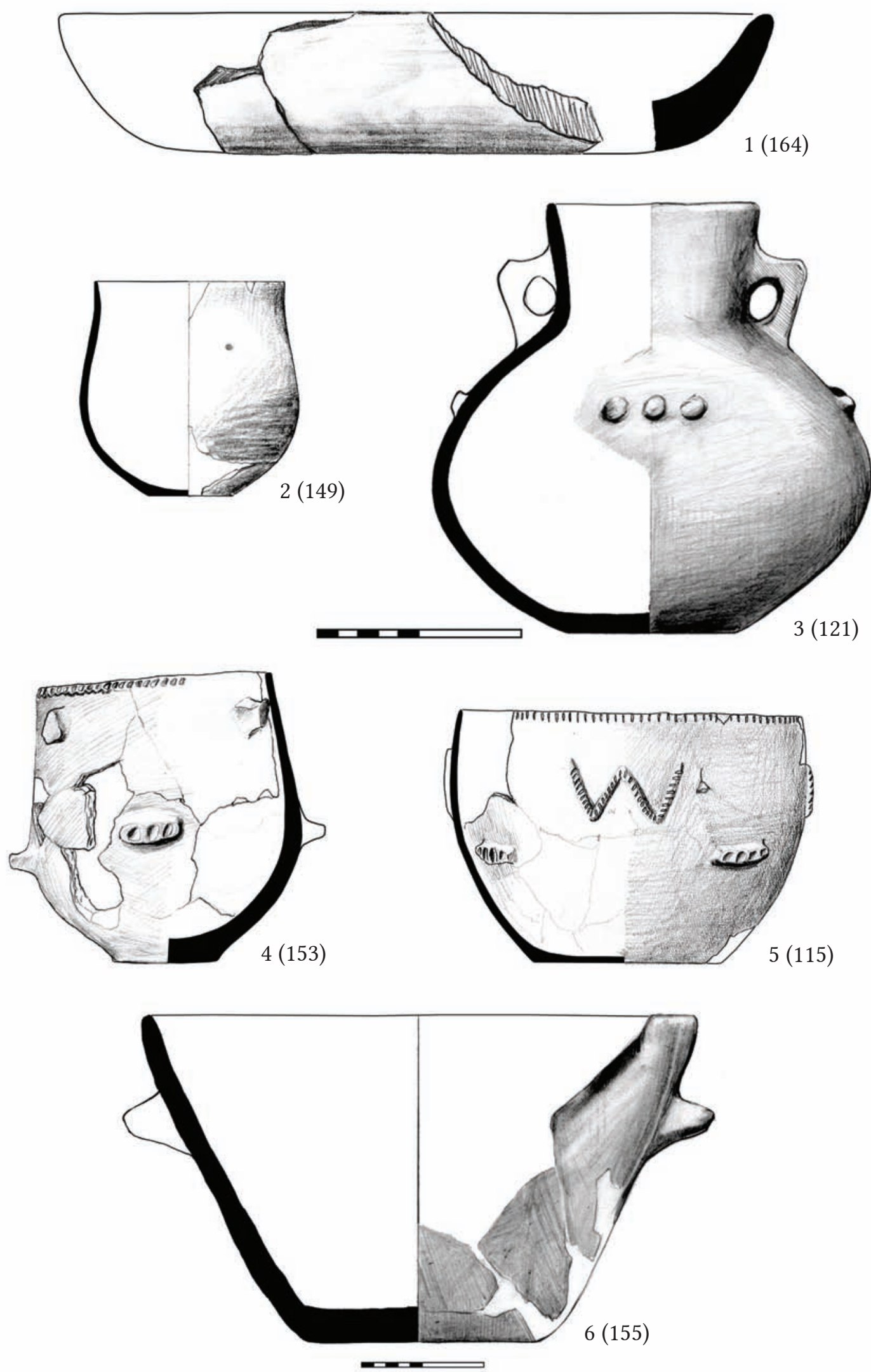

Fig. 64. Refitted vessels from uncertain contexts at Öcsöd-Kováshalom. 
Öcsöd-Kováshalom. Potscape of a Late Neolithic site in the Tisza region

\section{Appendix 1. Database of refitted vessels from Öcsöd-Kováshalom}

\begin{tabular}{|c|c|c|c|c|c|c|}
\hline$I D$ & Fig. & No. & Type & Rim diameter $(\mathrm{cm})$ & Max. diameter $(\mathrm{cm})$ & Height $(\mathrm{cm})$ \\
\hline 1 & 40 & 2 & T1d & 24 & 24 & 10.6 \\
\hline 2 & 40 & 4 & T1a & 30 & 30 & 5.8 \\
\hline 3 & 32 & 4 & $\mathrm{~T} 4$ & 10.05 & 11.4 & 12.2 \\
\hline 4 & 30 & 4 & T6 & 6.4 & 7.5 & 5.7 \\
\hline 5 & 32 & 3 & $\mathrm{~T} 8 \mathrm{~b}$ & 12.1 & 14.9 & 12.9 \\
\hline 6 & 31 & 1 & T6 & 11 & 15.8 & 13.2 \\
\hline 7 & 33 & 1 & T5 & 4 & 44.4 & 3.3 \\
\hline 8 & 33 & 5 & $\mathrm{~T} 2$ & 18.3 & 18.3 & 9.75 \\
\hline 9 & 33 & 4 & $\mathrm{~T} 4$ & 11.8 & 13.2 & 13.5 \\
\hline 10 & 33 & 6 & T3b & 12.7 & 13.9 & 6 \\
\hline 11 & 33 & 7 & T9 & 7.3 & 16.9 & 18.3 \\
\hline 12 & 61 & 4 & $\mathrm{~T} 4$ & 11.4 & 11.4 & 12.3 \\
\hline 13 & 37 & 8 & $\mathrm{~T} 8 \mathrm{~b}$ & 14.7 & 15.5 & 14.5 \\
\hline 14 & 41 & 6 & T9 & 11.1 & 16.3 & 21.45 \\
\hline 15 & 37 & 5 & T3b & 18.3 & 19.6 & 8.4 \\
\hline 16 & 37 & 7 & T3a & 17.2 & 18.5 & 10.6 \\
\hline 17 & 37 & 6 & T3b & 18.6 & 19.2 & 7.6 \\
\hline 18 & 37 & 4 & T12a & 17.25 & 17.25 & 7.9 \\
\hline 19 & 36 & 3 & T11 & - & 14 & 10.5 \\
\hline 20 & 37 & 1 & T3b & 19.5 & 19.5 & 8.25 \\
\hline 21 & 37 & 3 & $\mathrm{~T} 2$ & 20.4 & 20.4 & 11.2 \\
\hline 22 & 37 & 2 & $\mathrm{~T} 1 \mathrm{c}$ & 17.3 & 17.3 & 7.1 \\
\hline 23 & 61 & 1 & T3b & 10.9 & 10.9 & 5.1 \\
\hline 24 & 30 & 6 & $\mathrm{~T} 2$ & 15 & 15 & 8.1 \\
\hline 25 & 30 & 8 & T3b & 18.7 & 20.1 & 8.7 \\
\hline 26 & 34 & 4 & T6 & 12.2 & 15.7 & 14.3 \\
\hline 27 & 61 & 2 & T3b & 15 & 15.5 & 7.2 \\
\hline 28 & 32 & 5 & $\mathrm{~T} 12 \mathrm{~b}$ & 20.25 & 20.25 & 1 \\
\hline 29 & 33 & 2 & $\mathrm{~T} 4$ & 10.65 & 11.2 & 12.2 \\
\hline 30 & 31 & 4 & T6 & 8.6 & 9.2 & 9.3 \\
\hline 31 & 34 & 5 & T9 & 9.9 & 9.9 & 21.5 \\
\hline 32 & 34 & 7 & T3c & 10.8 & 11.7 & 4.9 \\
\hline 33 & 45 & 6 & T3b & 22 & 22.4 & 10.4 \\
\hline 34 & 34 & 6 & $\mathrm{~T} 4$ & 11.4 & 11.8 & 13.2 \\
\hline 35 & 61 & 10 & T7 & 4.2 & 4.2 & 4.1 \\
\hline 36 & 52 & 2 & $\mathrm{~T} 7$ & 18 & 18 & 14.5 \\
\hline 37 & 34 & 2 & T1d & 17 & 17 & 5.3 \\
\hline 38 & 63 & 2 & $\mathrm{~T} 3 \mathrm{~b}$ & 20.8 & 21.3 & 7.8 \\
\hline 39 & 30 & 7 & T3b & 15.3 & 15.3 & 6.8 \\
\hline
\end{tabular}


András FüZESI - Pál RACZKY

\begin{tabular}{|c|c|c|c|c|c|c|}
\hline$I D$ & Fig. & No. & Type & Rim diameter $(\mathrm{cm})$ & Max. diameter $(\mathrm{cm})$ & Height $(\mathrm{cm})$ \\
\hline 40 & 57 & 1 & T8b & 18.6 & 19 & 16.7 \\
\hline 41 & 42 & 5 & $\mathrm{~T} 7$ & 21.15 & 21.5 & 19.05 \\
\hline 42 & 33 & 8 & $\mathrm{~T} 3 \mathrm{~b}$ & 21.6 & 22.2 & 8.4 \\
\hline 43 & 52 & 8 & $\mathrm{~T} 3 \mathrm{~b}$ & 16.6 & 17.3 & 8.1 \\
\hline 44 & 38 & 3 & T6 & 8.7 & 13.8 & 15.4 \\
\hline 45 & 38 & 1 & $\mathrm{~T} 12 \mathrm{~b}$ & 11.2 & 11.2 & 1 \\
\hline 46 & 50 & 7 & $\mathrm{~T} 8 \mathrm{~b}$ & 14.25 & 15.9 & 15.6 \\
\hline 47 & 30 & 1 & T5 & 19 & 20.5 & 21 \\
\hline 48 & 39 & 2 & $\mathrm{~T} 3 \mathrm{~b}$ & 17.25 & 18.1 & 8.6 \\
\hline 49 & 43 & 4 & $\mathrm{~T} 8 \mathrm{~b}$ & 11.3 & 13.5 & 13.2 \\
\hline 50 & 35 & 1 & T5 & 3.8 & 3.8 & 6.4 \\
\hline 51 & 43 & 2 & $\mathrm{~T} 2$ & 3.8 & 3.8 & 3 \\
\hline 52 & 43 & 7 & $\mathrm{~T} 10$ & 23.1 & 23.1 & 42.6 \\
\hline 53 & 55 & 8 & $\mathrm{~T} 3 \mathrm{c}$ & 16.35 & 16.35 & 7.8 \\
\hline 54 & 55 & 6 & T3c & 18 & 19.6 & 7.9 \\
\hline 55 & 55 & 10 & T3c & 20 & 20.5 & 8.4 \\
\hline 56 & 55 & 7 & T3c & 18.9 & 19.3 & 6.6 \\
\hline 57 & 35 & 2 & T5 & 6.5 & 6.5 & 6.1 \\
\hline 58 & 55 & 1 & $\mathrm{~T} 2$ & 7.8 & 7.8 & 4.6 \\
\hline 59 & 55 & 11 & $\mathrm{~T} 3 \mathrm{~b}$ & 13.5 & 14.8 & 6.8 \\
\hline 60 & 56 & 4 & $\mathrm{~T} 4$ & 11.6 & 12.5 & 12.6 \\
\hline 61 & 56 & 6 & $\mathrm{~T} 4$ & 10.2 & 11.6 & 12.15 \\
\hline 62 & 55 & 4 & T12a & 15.6 & 15.6 & 6 \\
\hline 63 & 55 & 5 & T3c & 13.2 & 13.6 & 5.8 \\
\hline 64 & 56 & 2 & $\mathrm{~T} 8 \mathrm{~b}$ & 14.4 & 17.1 & 15.7 \\
\hline 65 & 47 & 1 & T5 & 12.6 & 14.3 & 13.35 \\
\hline 66 & 46 & 8 & $\mathrm{~T} 1 \mathrm{~b}$ & 13.5 & 13.5 & 3.5 \\
\hline 67 & 46 & 5 & T3b & 16.1 & 16.9 & 6.6 \\
\hline 68 & 46 & 6 & T3c & 12.1 & 12.6 & 5.6 \\
\hline 69 & 46 & 7 & $\mathrm{~T} 2$ & 7 & 7 & 4.6 \\
\hline 70 & 50 & 2 & T1c & 11.2 & 11.2 & 4.8 \\
\hline 71 & 50 & 1 & T5 & 7.9 & 8.1 & 6.5 \\
\hline 72 & 50 & 6 & $\mathrm{~T} 8 \mathrm{~b}$ & 13.05 & 13.2 & 15.45 \\
\hline 73 & 50 & 10 & T3c & 17.2 & 17.2 & 7.8 \\
\hline 74 & 52 & 3 & T10 & 23.3 & 23.3 & 25.8 \\
\hline 75 & 51 & 2 & T5 & 10.3 & 10.9 & 11.2 \\
\hline 76 & 54 & 2 & $\mathrm{~T} 1 \mathrm{~b}$ & 10.8 & 10.8 & 3.4 \\
\hline 77 & 54 & 5 & T3c & 17.7 & 18 & 8.3 \\
\hline 78 & 52 & 4 & $\mathrm{~T} 4$ & 6.7 & 7.8 & 7.4 \\
\hline 79 & 52 & 6 & $\mathrm{~T} 2$ & 18 & 18 & 8.41 \\
\hline
\end{tabular}


Öcsöd-Kováshalom. Potscape of a Late Neolithic site in the Tisza region

\begin{tabular}{|c|c|c|c|c|c|c|}
\hline$I D$ & Fig. & No. & Type & Rim diameter $(\mathrm{cm})$ & Max. diameter $(\mathrm{cm})$ & Height $(\mathrm{cm})$ \\
\hline 80 & 41 & 4 & $\mathrm{~T} 4$ & 12.3 & 12.8 & 11.9 \\
\hline 81 & 47 & 4 & T8c & 10.2 & 11.3 & 8.1 \\
\hline 82 & 47 & 5 & T5 & 9.8 & 10.6 & 9.2 \\
\hline 83 & 47 & 8 & $\mathrm{~T} 8 \mathrm{~b}$ & 17.5 & 20.3 & 18.4 \\
\hline 84 & 47 & 6 & $\mathrm{~T} 8 \mathrm{~b}$ & 12.8 & 14.9 & 14.6 \\
\hline 85 & 47 & 7 & $\mathrm{~T} 8 \mathrm{c}$ & 19.8 & 19.8 & 15.9 \\
\hline 86 & 45 & 5 & T12a & 16.3 & 16.3 & 6.5 \\
\hline 87 & 63 & 4 & $\mathrm{~T} 3 \mathrm{~b}$ & 18 & 18 & 8.8 \\
\hline 88 & 45 & 1 & T6 & 12.2 & 15.7 & 13.3 \\
\hline 89 & 44 & 6 & $\mathrm{~T} 2$ & 17.6 & 17.6 & 9.1 \\
\hline 90 & 44 & 5 & T3c & 17.1 & 17.6 & 7.8 \\
\hline 91 & 44 & 2 & T12a & 14.25 & 14.25 & 6.5 \\
\hline 92 & 44 & 7 & $\mathrm{~T} 1 \mathrm{~b}$ & 26 & 26 & 5.7 \\
\hline 93 & 44 & 1 & $\mathrm{~T} 12 \mathrm{~b}$ & 8.8 & 8.8 & 1 \\
\hline 94 & 44 & 10 & $\mathrm{~T} 8 \mathrm{~b}$ & 19.4 & 24.2 & 22.4 \\
\hline 95 & 44 & 9 & $\mathrm{~T} 8 \mathrm{~b}$ & 16.6 & 19.5 & 16.8 \\
\hline 96 & 44 & 8 & $\mathrm{~T} 8 \mathrm{c}$ & 26.2 & 26.2 & 22 \\
\hline 97 & 32 & 2 & T1c & 18.75 & 18.75 & 11.25 \\
\hline 98 & 32 & 1 & T3b & 17.8 & 18 & 8.9 \\
\hline 99 & 57 & 5 & $\mathrm{~T} 8 \mathrm{~b}$ & 12.6 & 14.3 & 16.2 \\
\hline 100 & 49 & 6 & $\mathrm{~T} 2$ & 5.1 & 5.1 & 3.8 \\
\hline 101 & 45 & 2 & $\mathrm{~T} 2$ & 18.2 & 18.2 & 12 \\
\hline 102 & 54 & 1 & T5 & 8 & 8 & 6.7 \\
\hline 103 & 54 & 3 & T5 & 11.4 & 11.9 & 9.4 \\
\hline 104 & 54 & 4 & T1c & 10.7 & 10.7 & 4.7 \\
\hline 105 & 52 & 1 & $\mathrm{~T} 7$ & 11.7 & 11.7 & 12.15 \\
\hline 106 & 51 & 5 & $\mathrm{~T} 7$ & 19 & 19 & 17 \\
\hline 107 & 42 & 6 & T1a & 34.7 & 34.7 & 5.1 \\
\hline 108 & 41 & 3 & T5 & 11.7 & 12.9 & 11.9 \\
\hline 109 & 52 & 5 & $\mathrm{~T} 1 \mathrm{~b}$ & 21.3 & 21.3 & 5.4 \\
\hline 110 & 48 & 6 & $\mathrm{~T} 11$ & 15 & 15 & 13.2 \\
\hline 111 & 48 & 2 & T9 & 8.4 & 16.5 & 21.5 \\
\hline 112 & 48 & 4 & T12a & 19.4 & 19.4 & 8.6 \\
\hline 113 & 48 & 1 & T9 & 7.5 & 15.2 & 20.2 \\
\hline 114 & 49 & 2 & T8a & 14.2 & 14.2 & 16.3 \\
\hline 115 & 64 & 5 & T5 & 27.5 & 27.5 & 18.6 \\
\hline 116 & 49 & 1 & $\mathrm{~T} 8 \mathrm{a}$ & 16.5 & 18 & 18.2 \\
\hline 117 & 48 & 3 & T9 & 7 & 7 & 18.4 \\
\hline 118 & 55 & 9 & T3b & 19.8 & 19.8 & 8.3 \\
\hline 119 & 46 & 4 & $\mathrm{~T} 3 \mathrm{~b}$ & 16 & 17.6 & 10.4 \\
\hline 120 & 59 & 3 & T9 & 6 & 6 & 9.5 \\
\hline
\end{tabular}


András FÜZESI - Pál RACZKy

\begin{tabular}{|c|c|c|c|c|c|c|}
\hline$I D$ & Fig. & No. & Type & Rim diameter $(\mathrm{cm})$ & Max. diameter $(\mathrm{cm})$ & Height $(\mathrm{cm})$ \\
\hline 121 & 64 & 3 & T9 & 10.5 & 21.3 & 21 \\
\hline 122 & 40 & 1 & $\mathrm{~T} 12 \mathrm{~b}$ & 20.8 & 20.8 & 1 \\
\hline 123 & 34 & 1 & T12a & 9.2 & 9.2 & 5.3 \\
\hline 124 & 30 & 5 & $\mathrm{~T} 4$ & 10.7 & 12.3 & 13.1 \\
\hline 125 & 40 & 5 & $\mathrm{~T} 4$ & 11.4 & 12.5 & 12.4 \\
\hline 126 & 31 & 6 & $\mathrm{~T} 4$ & 9.6 & 9.9 & 11.1 \\
\hline 127 & 61 & 9 & $\mathrm{~T} 5$ & 8.1 & 8.7 & 8.5 \\
\hline 128 & 36 & 4 & $\mathrm{~T} 6$ & 11.2 & 15.3 & 13.1 \\
\hline 129 & 35 & 7 & $\mathrm{~T} 2$ & 12.6 & 13 & 6.9 \\
\hline 130 & 52 & 7 & $\mathrm{~T} 3 \mathrm{c}$ & 13.7 & 14.6 & 6.7 \\
\hline 131 & 32 & 7 & $\mathrm{~T} 11$ & 22.5 & 22.5 & 6.7 \\
\hline 132 & 44 & 3 & T12a & 17 & 17 & 13.95 \\
\hline 133 & 34 & 3 & T12a & 9 & 9 & 6.4 \\
\hline 134 & 33 & 9 & T5 & 10.3 & 10.8 & 8.9 \\
\hline 135 & 49 & 7 & $\mathrm{~T} 4$ & 10.35 & 10.8 & 11.7 \\
\hline 136 & 31 & 3 & $\mathrm{~T} 2$ & 12.3 & 12.3 & 7.3 \\
\hline 137 & 63 & 3 & T1d & 22.5 & 22.5 & 7.35 \\
\hline 138 & 35 & 3 & $\mathrm{~T} 5$ & 6.8 & 6.8 & 5.5 \\
\hline 139 & 40 & 3 & $\mathrm{~T} 1 \mathrm{c}$ & 11.7 & 11.7 & 6.8 \\
\hline 140 & 49 & 4 & $\mathrm{~T} 3 \mathrm{~b}$ & 18.2 & 19.6 & 8.5 \\
\hline 141 & 61 & 6 & T5 & 15.1 & 15.5 & 14.5 \\
\hline 142 & 61 & 3 & T9 & 7.8 & 15.6 & 18.5 \\
\hline 143 & 61 & 11 & T5 & 2.9 & 3.4 & 2 \\
\hline 144 & 43 & 6 & $\mathrm{~T} 2$ & 8.2 & 8.2 & 4.8 \\
\hline 145 & 61 & 5 & T5 & 12.5 & 12.5 & 11.8 \\
\hline 146 & 44 & 4 & $\mathrm{~T} 3 \mathrm{~b}$ & 20.2 & 22.5 & 7.8 \\
\hline 147 & 30 & 3 & $\mathrm{~T} 2$ & 16.8 & 16.8 & 7.5 \\
\hline 148 & 48 & 5 & T5 & 12.4 & 12.4 & 10.6 \\
\hline 149 & 64 & 2 & $\mathrm{~T} 4$ & 9.4 & 9.4 & 10.5 \\
\hline 150 & 30 & 2 & $\mathrm{~T} 2$ & 4.6 & 4.6 & 2.8 \\
\hline 151 & 39 & 1 & T5 & 16.8 & 16.8 & 13.4 \\
\hline 152 & 59 & 2 & T5 & 12.2 & 12.2 & 10.3 \\
\hline 153 & 64 & 4 & T8a & 18.3 & 18.3 & 21.6 \\
\hline 154 & 61 & 8 & $\mathrm{~T} 12 \mathrm{~b}$ & 11 & 11 & 1 \\
\hline 155 & 64 & 6 & T1c & 45 & 45 & 26.4 \\
\hline 156 & 63 & 1 & $\mathrm{~T} 2$ & 10.7 & 10.7 & 6.4 \\
\hline 157 & 63 & 6 & $\mathrm{~T} 1 \mathrm{c}$ & 15 & 15 & 6.5 \\
\hline 158 & 39 & 5 & T10 & 21.4 & 21.4 & 38 \\
\hline 159 & 41 & 5 & T6 & 13 & 13 & 14 \\
\hline 160 & 43 & 3 & $\mathrm{~T} 3 \mathrm{~b}$ & 26 & 26 & 14.8 \\
\hline 161 & 35 & 9 & $\mathrm{~T} 1 \mathrm{c}$ & 21 & 21 & 8 \\
\hline
\end{tabular}


Öcsöd-Kováshalom. Potscape of a Late Neolithic site in the Tisza region

\begin{tabular}{|c|c|c|c|c|c|c|}
\hline$I D$ & Fig. & No. & Type & Rim diameter $(\mathrm{cm})$ & Max. diameter $(\mathrm{cm})$ & Height $(\mathrm{cm})$ \\
\hline 162 & 39 & 3 & T3c & 13.6 & 15.5 & 9.4 \\
\hline 163 & 63 & 5 & T1d & 20 & 20 & 5.1 \\
\hline 164 & 64 & 1 & T1a & 34.8 & 34.8 & 6.9 \\
\hline 165 & 57 & 7 & T6 & 5 & 5 & 9 \\
\hline 166 & 56 & 5 & $\mathrm{~T} 2$ & 32 & 32 & 8.2 \\
\hline 167 & 54 & 6 & $\mathrm{~T} 1 \mathrm{~b}$ & 25 & 25 & 5 \\
\hline 168 & 39 & 9 & $\mathrm{~T} 2$ & 17.3 & 17.3 & 9.1 \\
\hline 169 & 38 & 2 & $\mathrm{~T} 2$ & 51 & 51 & 31 \\
\hline 170 & 39 & 10 & $\mathrm{~T} 4$ & 9 & 9 & 9.8 \\
\hline 171 & 43 & 1 & T1c & 11.7 & 11.7 & 5 \\
\hline 172 & 33 & 3 & T3c & 18 & 19 & 8 \\
\hline 173 & 58 & 5 & $\mathrm{~T} 5$ & 9.5 & 10.7 & 10.5 \\
\hline 174 & 58 & 6 & $\mathrm{~T} 4$ & 8.6 & 10.7 & 9.6 \\
\hline 175 & 58 & 7 & T1a & 38 & 7.9 & 7.9 \\
\hline 176 & 58 & 3 & T3b & 16.7 & 17.2 & 8.6 \\
\hline 177 & 37 & 9 & T1a & 39.4 & 8.4 & 8.4 \\
\hline 178 & 31 & 5 & T9 & 16 & 16 & 23 \\
\hline 179 & 49 & 5 & $\mathrm{~T} 8 \mathrm{~b}$ & 34 & 34 & 42 \\
\hline 180 & 47 & 3 & T3c & 8.1 & 8.1 & 4.3 \\
\hline 181 & 47 & 2 & $\mathrm{~T} 4$ & 11 & 9.5 & 9.5 \\
\hline 182 & 46 & 9 & T9 & 11 & 11 & 25 \\
\hline 183 & 46 & 1 & T12a & 4.8 & 4.8 & 2.6 \\
\hline 184 & 46 & 2 & $\mathrm{~T} 7$ & 12 & 12 & 13.9 \\
\hline 185 & 46 & 3 & $\mathrm{~T} 1 \mathrm{~d}$ & 15.4 & 15.4 & 6.4 \\
\hline 186 & 50 & 8 & T1a & 45 & 45 & 9.8 \\
\hline 187 & 50 & 4 & $\mathrm{~T} 1 \mathrm{~b}$ & 16.9 & 16.9 & 4.1 \\
\hline 188 & 50 & 5 & $\mathrm{~T} 1 \mathrm{~b}$ & 20.5 & 20.5 & 4.7 \\
\hline 189 & 50 & 3 & $\mathrm{~T} 1 \mathrm{~b}$ & 17.1 & 17.1 & 3.7 \\
\hline 190 & 45 & 4 & T3a & 16.2 & 16.6 & 5.8 \\
\hline 191 & 45 & 3 & $\mathrm{~T} 8 \mathrm{c}$ & 20.8 & 20.8 & 18.2 \\
\hline 192 & 40 & 6 & $\mathrm{~T} 11$ & 26 & 26 & 13 \\
\hline 193 & 62 & 1 & T9 & 55 & 120 & 170 \\
\hline 194 & 39 & 7 & $\mathrm{~T} 4$ & 10.7 & 10.7 & 10.5 \\
\hline 195 & 57 & 4 & T8a & 15 & 17.9 & 17.2 \\
\hline 196 & 57 & 3 & T3c & 13.8 & 13.8 & 6.2 \\
\hline 197 & 49 & 3 & $\mathrm{~T} 2$ & 17.6 & 17.6 & 10.7 \\
\hline 198 & 42 & 1 & $\mathrm{~T} 12 \mathrm{~b}$ & 17.8 & 17.8 & 1 \\
\hline 199 & 50 & 9 & T1a & 35 & 35 & 8.6 \\
\hline 200 & 57 & 6 & T3b & 10.8 & 10.8 & 5.7 \\
\hline 201 & 39 & 8 & T5 & 6.1 & 4.8 & 4.8 \\
\hline 202 & 31 & 2 & T3b & 10.5 & 10.5 & 6.5 \\
\hline
\end{tabular}


András FüZESI - Pál RACZKY

\begin{tabular}{|c|c|c|c|c|c|c|}
\hline$I D$ & Fig. & No. & Type & Rim diameter $(\mathrm{cm})$ & Max. diameter $(\mathrm{cm})$ & Height $(\mathrm{cm})$ \\
\hline 203 & 59 & 4 & T10 & 36.6 & 36.6 & 45.6 \\
\hline 204 & 56 & 3 & $\mathrm{~T} 7$ & 22.4 & 20.3 & 20.3 \\
\hline 205 & 54 & 7 & T1a & 35.4 & 35.4 & 8.2 \\
\hline 206 & 40 & 7 & $\mathrm{~T} 8 \mathrm{c}$ & 24.2 & 24.2 & 21.4 \\
\hline 207 & 59 & 1 & $\mathrm{~T} 4$ & 10.7 & 10.7 & 8.1 \\
\hline 208 & 55 & 2 & $\mathrm{~T} 1 \mathrm{~b}$ & 14.2 & 14.2 & 3.1 \\
\hline 209 & 55 & 3 & T1c & 15.1 & 15.1 & 6 \\
\hline 210 & 56 & 1 & $\mathrm{~T} 11$ & 15.2 & 15.2 & 5.3 \\
\hline 211 & 38 & 5 & T1a & 48 & 48 & 7.6 \\
\hline 212 & 38 & 4 & $\mathrm{~T} 1 \mathrm{~b}$ & 21.9 & 21.9 & 4.7 \\
\hline 213 & 58 & 2 & $\mathrm{~T} 1 \mathrm{c}$ & 15.7 & 15.7 & 6.5 \\
\hline 214 & 58 & 1 & $\mathrm{~T} 2$ & 13 & 13 & 7.3 \\
\hline 215 & 58 & 4 & $\mathrm{~T} 4$ & 7.6 & 7.6 & 9.7 \\
\hline 216 & 41 & 7 & $\mathrm{~T} 1 \mathrm{a}$ & 36.4 & 36.4 & 7.9 \\
\hline 217 & 42 & 4 & T1a & 32.4 & 32.4 & 6.8 \\
\hline 218 & 41 & 8 & $\mathrm{~T} 1 \mathrm{~b}$ & 25.6 & 25.6 & 5 \\
\hline 219 & 42 & 3 & $\mathrm{~T} 1 \mathrm{a}$ & 38.2 & 38.2 & 8.2 \\
\hline 220 & 41 & 1 & $\mathrm{~T} 7$ & 8.5 & 8.5 & 7 \\
\hline 221 & 42 & 2 & $\mathrm{~T} 1 \mathrm{a}$ & 36.8 & 36.8 & 7.8 \\
\hline 222 & 41 & 2 & $\mathrm{~T} 1 \mathrm{~d}$ & 18.9 & 18.9 & 6.1 \\
\hline 223 & 39 & 6 & T3a & 10.1 & 8.5 & 8.5 \\
\hline 224 & 39 & 4 & $\mathrm{~T} 12 \mathrm{~b}$ & 9.9 & 9.9 & 1 \\
\hline 225 & 51 & 6 & $\mathrm{~T} 7$ & 11.7 & 11.7 & 11.3 \\
\hline 226 & 51 & 3 & T8a & 17.8 & 20.6 & 20.6 \\
\hline 227 & 51 & 1 & T6 & 12.4 & 17.7 & 11.7 \\
\hline 228 & 32 & 6 & T9 & 23 & 49 & 62 \\
\hline 229 & 51 & 4 & $\mathrm{~T} 1 \mathrm{a}$ & 30.8 & 30.8 & 6.2 \\
\hline 230 & 60 & 1 & T9 & 18 & 40 & 55 \\
\hline 231 & 53 & 1 & T11 & 7.2 & 11.8 & 17 \\
\hline 232 & 57 & 2 & $\mathrm{~T} 1 \mathrm{a}$ & 36.4 & 36.4 & 7.2 \\
\hline 233 & 43 & 5 & $\mathrm{~T} 1 \mathrm{c}$ & 10.3 & 10.3 & 5.3 \\
\hline 234 & 45 & 7 & T6 & 9.2 & 11.5 & 11.5 \\
\hline 235 & 61 & 7 & $\mathrm{~T} 8 \mathrm{~b}$ & 7.1 & 7.8 & 7.8 \\
\hline 236 & 35 & 6 & T3b & 19 & 9.8 & 9.8 \\
\hline 237 & 35 & 8 & $\mathrm{~T} 2$ & 15.1 & 15.1 & 9.1 \\
\hline 238 & 36 & 1 & $\mathrm{~T} 8 \mathrm{~b}$ & 13.5 & 17.3 & 17.3 \\
\hline 239 & 35 & 5 & $\mathrm{~T} 5$ & 15.2 & 15.2 & 12 \\
\hline 240 & 36 & 2 & T3b & 28.8 & 13.8 & 13.8 \\
\hline 241 & 35 & 4 & $\mathrm{~T} 2$ & 21 & 21 & 6.8 \\
\hline
\end{tabular}

